PNL 10524

BSRC - 800/95/003

\title{
Arid Sites Stakeholder Paritipcation in Evaluating Innovative Technologies: VOC-Arid Site Integrated Demonstration
}

\author{
T.S. Peterson \\ P.J. Serie \\ G.H. McCabe \\ K.A. Niesen \\ B.R. Brockbank
}

May 1995

RECEIV:

MAY 311995

OSTI

Prepared for the U.S. Department of Energy's

Office of Technology Development under

Contract DE-AC06-76RLO 1830

Pacific Northwest Laboratory

Operated for the U.S. Department of Energy

by Battelle Memorial Institute 


\title{
DISCLAIMER
}

This report was prepared as an account of work sponsored by an agency of the United States Government. Neither the United States Government nor any agency thereof, nor Battelle Memorial Institute, nor any of their employees, makes any warranty, expressed or implied, or assumes any legal liability or responsibility for the accuracy, completeness, or usefulness of any information, apparatus, product, or process disclosed, or represents that its use would not infringe privately owned rights. Reference herein to any specific commercial product, process, or service by trade name, trademark, manufacturer, or otherwise does not necessarily constitute or imply its endorsement, recommendation, or favoring by the United States Government or any agency thereof, or Battelle Memorial Institute. The views and opinions of authors expressed herein do not necessarily state or reflect those of the United States Government or any agency thereof.

\author{
PACIFIC NORTHWEST LABORATORY \\ operated by \\ BATTELLE MEMORIAL INSTTTUTE \\ for the \\ UNITED STATES DEPARTMENT OF ENERGY \\ under Contract DE-ACD6-76RLO 1830
}

Printed in the United States of America

Available to DOE and DOE contractors from the

Office of Scientific and Technical Information, P.O. Box 62, Oak Ridge, TN 37831; prices available from (615) 576-8401, FTS 626-8401.

Available to the public from the National Technical Information Service, U.S. Department of Commerce, 5285 Port Royal Rd., Springfield, VA 22161. 


\section{ARID SITES STAKEHOLDER PARTICIPATION IN EVALUATING INNOVATIVE TECHNOLOGIES: VOC-ARID SITE INTEGRATED DEMONSTRATION* \\ for \\ U.S. Department of Energy \\ Office of Technology Development}

\section{Prepared by: \\ Todd Peterson Gretchen McCabe Bradley Brockbank}

Battelle Seattle Research Center and Pacific Northwest Laboratory

and

Patricia Serie Kathleen Niesen

EnviroIssues Seattle, Washington

May 1995

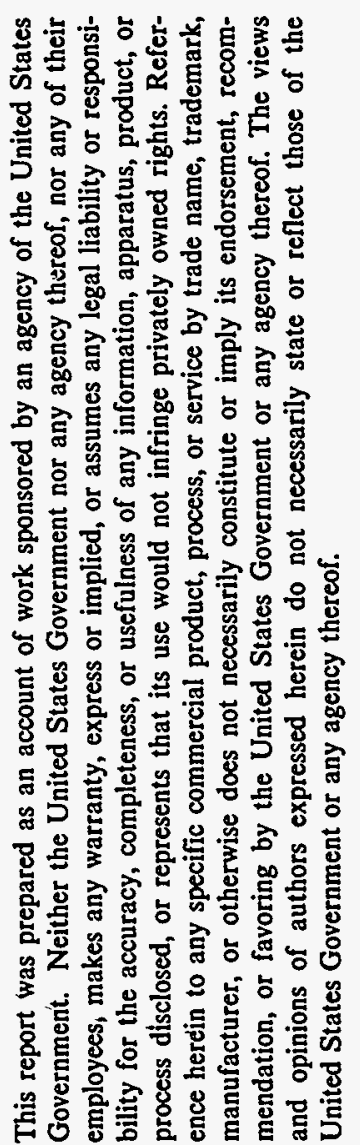

* The VOC-Arid Site Integrated Demonstration has been transitioned into the Department of Energy's Plume Focus Area. 


\section{DISCLAIMER}

Portions of this document may be illegible in electronic image products. Images are produced from the best available original document. 


\section{TABLE OF CONTENTS}

EXECUTIVE SUMMARY $\ldots \ldots \ldots \ldots \ldots \ldots \ldots \ldots \ldots \ldots \ldots \ldots \ldots \ldots \ldots \ldots$

1.0 INTRODUCTION . . . . . . . . . . . . . . . . . . . . . . . 1-1

1.1 PURPOSE AND OBJECTIVES OF ARID SITES' STAKEHOLDER

PARTICIPATION IN TECHNOLOGY EVALUATION $\ldots \ldots \ldots \ldots \ldots \ldots .1-1$

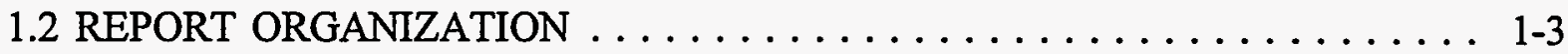

2.0 STAKEHOLDER PARTICIPATION METHODOLOGY ............ 2-1

2.1 OVERALL APPROACH TO STAKEHOLDER PARTICIPATION $\ldots \ldots \ldots .2-1$

2.2 SPECIFIC METHODOLOGY TO INVOLVE STAKEHOLDERS $\ldots \ldots \ldots .2-1$

3.0 DESCRIPTION OF TECHNOLOGIES . . . . . . . . . . . . . . . 3-1

3.1 GROUND WATER REMEDIATION SYSTEM TECHNOLOGIES . . . . . . 3-1

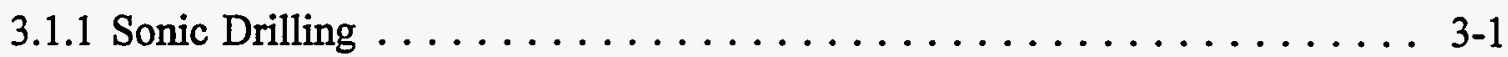

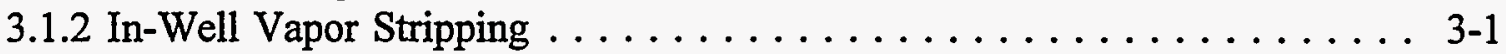

3.1.3 Membrane Separation . . . . . . . . . . . . . . . . . . 3-2

3.1.4 In-Situ Bioremediation . . . . . . . . . . . . . . . . .

3.2 SOIL REMEDIATION SYSTEM TECHNOLOGIES . . . . . . . . 3-3

3.2.1 Passive Soil Vapor Extraction Using Borehole Flux . . . . . . . . . 3-3

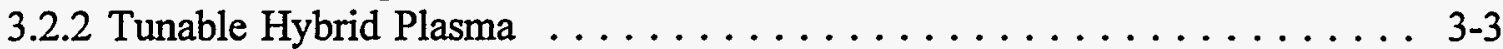

4.0 SUMMARY OF STAKEHOLDER INTERVIEW RESULTS $\ldots \ldots \ldots \ldots \ldots$. 4 - .

4.1 SUMMARY OF STAKEHOLDER INPUT $\ldots \ldots \ldots \ldots \ldots \ldots \ldots \ldots \ldots$. $\ldots \ldots$

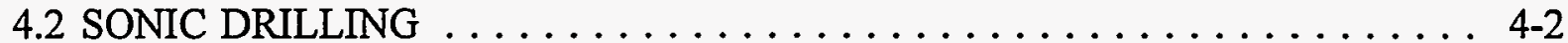

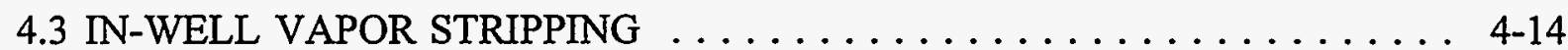

4.4 MEMBRANE SEPARATION .................... 4-26

4.5 IN-SITU BIOREMEDIATION $\ldots \ldots \ldots \ldots \ldots \ldots \ldots \ldots \ldots \ldots$ 4 . $\ldots \ldots$

4.6 PASSIVE SOIL VAPOR EXTRACTION $\ldots \ldots \ldots \ldots \ldots \ldots \ldots \ldots .4-55$

4.7 TUNABLE HYBRID PLASMA TREATMENT . . . . . . . . . . . 4-69

APPENDIX A TECHNOLOGY FACT SHEETS AND PROFILES $\ldots \ldots \ldots \ldots \ldots$ A-1 


\section{EXECUTIVE SUMMARY}

\section{INTRODUCTION AND BACKGROUND}

Developing and deploying innovative environmental cleanup technologies is an important goal for the U.S. Department of Energy (DOE), which faces challenging remediation problems at contaminated sites throughout the United States. Achieving meaningful, constructive stakeholder involvement in cleanup programs, with the aim of ultimate acceptance of remediation decisions, is critical to meeting those challenges. DOE's Office of Technology Development sponsors research and demonstration of new technologies, including, in the past, the Volatile Organic Compounds Arid Site Integrated Demonstration (VOC-Arid ID) ${ }^{1}$, hosted at the Hanford Site in Washington State. The purpose of the VOC-Arid.ID has been to develop and demonstrate new technologies for remediating carbon tetrachloride and other VOC contamination in soils and ground water. In October 1994 the VOC-Arid ID became a part of the Contaminant Plume Containment and Remediation Focus Area (Plume Focus Area). The VOC Arid ID's purpose of involving stakeholders in evaluating innovative technologies will now be carried on in the Plume Focus Area in cooperation with Site Technology Coordination Groups and Site Specific Advisory Boards. DOE's goal is to demonstrate promising technologies once and deploy those that are successful across the DOE complex. Achieving that goal requires that the technologies be acceptable to the groups and individuals with a stake in DOE facility cleanup.

Such stakeholders include groups and individuals with an interest in cleanup, including regulatory agencies, Native American tribes, environmental and civic interest groups, public officials, environmental technology users, and private citizens. This report documents the results of the stakeholder involvement program, which is an integral part of the VOC-Arid ID. It reflects a regional approach, undertaken to add the perspectives of stakeholders from other sites to those of the Hanford Site community. It provides evidence for the conclusion that involving stakeholders on a regional basis adds significant value to a stakeholder involvement program, for two principal reasons:

- First, regional stakeholder involvement has validated the technology evaluation criteria developed by Hanford stakeholders. The ID now has a shared set of criteria, expressing broadly-held stakeholder priorities for technologies' technical effectiveness and practicality. This validation was augmented by site-specific interpretations of the criteria, which are critical to designing technology development and demonstration to achieve broad acceptance.

- Second, regional stakeholders validated Hanford stakeholders' application of the criteria to six innovative technologies. Regional stakeholders shared many of the concerns articulated by Hanford stakeholders. In addition, however, and most important, the regional effort defined local concerns that could determine the

'The technology development activities of the VOC-Arid ID will now be addressed through the Plume Focus Area, part of DOE's new approach to development and deployment of innovative environmental management technologies. 
deployability of the technologies at DOE's other arid sites. These site-specific issues, while not as numerous as the commonly-held perspectives, could prove to be fatal impediments to technology deployment unless they are successfully addressed in development and demonstration of the technologies. Much of the information gathered, in fact, will be applicable to any new technologies slated for deployment across the DOE complex.

This report provides perspectives on technology acceptability that can be used for several purposes:

- To give technology developers, demonstrators, and deployers an understanding of the issues and information that are important to the broad range of stakeholders in evaluating the acceptability of innovative technologies, and to allow developers to organize issues and information within the framework of the technology evaluation criteria developed by stakeholders.

- To identify the site- and region-specific factors and influences that affect the acceptability of new technologies, and that may determine acceptance in a particular location or locations; in this way developers may be able to refine their demonstration plans to address the local concerns, or may be forewarned about problems at a particular site that may be crucial to technology acceptance there.

- To determine whether there is likely to be sufficient variability among stakeholder perspectives in different parts of the country to warrant site-specific stakeholder consultation in technology development, aiding in designing future stakeholder involvement.

\section{METHODOLOGY FOR STAKEHOLDER INVOLVEMENT}

The ID team sought out and recorded stakeholder values and information needs in the early stages of technology demonstration so that those values and needs could be incorporated into demonstration planning. A full compilation of stakeholder comments, issues, and concerns was provided to the technology developers for review and use in developing plans and conducting demonstrations. Demonstration results will later be provided to stakeholders to allow them to assess the acceptability of the technologies for deployment. The resulting stakeholder assessment information will help DOE and industry decision makers select remediation methods that will be acceptable to a broad range of stakeholders, thereby expediting cleanup.

Stakeholder involvement in the VOC-Arid ID began with the participation of Hanford stakeholders, who joined in defining criteria for evaluating innovative technologies and then applied those criteria to six ground-water and soil remediation technologies that are part of the VOC-Arid ID. The criteria developed reflected stakeholder concerns and values. Stakeholder input fell into these four categories of criteria:

- Effectiveness of the technology -- performance, cost, and time 
- Environmental safety and health -- worker and public health and safety, and environmental impacts

- Socio-political interests -- public perception, tribal rights and future land uses, and socio-economic interests

- $\quad$ Regulatory objectives -- compatibility with cleanup milestones, regulatory infrastructure and track record, and regulatory compliance.

Criteria development activities and subsequent Hanford stakeholder input on the technologies are documented in earlier reports. This report documents expanded consultation with stakeholders at other DOE arid sites to confirm and apply the criteria, incorporating the perspectives and information needs of those sites' stakeholders in the demonstrations. In this way, a technology, which may be ultimately considered for deployment at many sites, can be demonstrated so as to reflect a broader and more complete understanding of regional stakeholder values. By conducting the stakeholder participation process first at Hanford, then expanding it to the other sites, it is possible to evaluate similarities and differences among stakeholders' perspectives in various regions. The four sites that participated, in addition to Hanford, were Sandia National Laboratories and Los Alamos National Laboratory in New Mexico, the Idaho National Engineering Laboratory, and the Rocky Flats Site in Colorado.

The ID team employed a multi-step process to involve stakeholders in evaluating six innovative technologies. The steps included:

- Developing information about the technologies for stakeholders (technology profiles, fact sheets, and evaluation criteria summaries).

- Contacting personnel at each site to learn about stakeholder involvement at those sites, and meeting with site representatives to develop site-specific strategies for involving local stakeholders in the ID.

- Identifying a cross section of stakeholders, and contacting them to assess their willingness to participate and to schedule interviews.

- Distributing the technology information for review, prior to the interviews, to the stakeholders who agreed to be interviewed.

- $\quad$ Conducting interviews in which the ID team explained its objectives, answered stakeholder questions about the technologies, and asked the people interviewed about their views on the technologies.

The interviews focused on learning what is important to the stakeholders in choosing an environmental restoration technology, and what additional information they would need about the technology in order to evaluate it for deployment. Stakeholders were asked about issues and concerns raised by the technologies, and were asked about their views on the advantages and disadvantages of the technologies compared with current baseline technologies. 
The results of the interviews have been analyzed and summarized in this report, using earlier published input from Hanford stakeholders to illuminate common themes among the sites as well as to highlight site- or region-specific issues and perspectives.

\section{DESCRIPTION OF THE DEMONSTRATION TECHNOLOGIES}

Stakeholders evaluated six innovative remediation technologies that are being demonstrated within the VOC-Arid ID. They represented different types of technologies (e.g., subsurface access, contaminant extraction, and contaminant treatment). For ease of discussion, they were grouped into two systems, though each is a technology that could be used alone or in combination with other technologies. The six technologies are:

\section{Ground-Water Technologies:}

- Sonic Drilling is a subsurface access technology, which uses resonant vibration to cut a boring. No drilling fluids are needed, and there is minimal secondary waste (e.g., drill cuttings) produced.

- In-Well Vapor Stripping is a contaminant extraction technology which removes VOCs from ground water as vapor. Only the vapor then requires handling, and it is treated at the surface. In-well vapor stripping operates somewhat like a fish tank filter system, passing VOC-laden ground water repeatedly through the in-well system.

- Membrane Separation is an above-ground treatment system that condenses and captures contaminants emerging from underground in vapor form. The technology uses thin-film membranes to concentrate the gases.

- In-Situ Bioremediation uses naturally occurring microorganisms in ground water, stimulated by the addition of nutrients, to clegrade VOCs in place. There is no need to pump the ground water to the surface for treatment.

\section{Soil Technologies:}

- Passive Soil Vapor Extraction takes advantage of natural atmospheric pressure changes to bring contaminant vapor to the surface through wells or boreholes. Potential enhancements include turbines or windmills at the surface, injection of hot air or steam, and one-way flow valves.

- Tunable Hybrid Plasma is an above-ground technology that can treat vapor extracted from either soil or ground water. It uses an electron beam to destroy VOC molecules, producing other molecules that can be scrubbed and reduced to salt.

\section{COMMON DEMONSTRATION ISSUES}

A number of themes emerged from the interviews held with stakeholders at Hanford, as documented in earlier reports. They include the following major objectives for the technology development and demonstration process, regardless of the type of technology: 
- Define remediation objectives clearly, ensuring that the technology truly contributes to these objectives.

- Compare new technologies with existing technologies in an integrated, "total treatment train" manner.

- Design demonstrations to provide credible data on performance, cost, and time in order to reduce uncertainty and define technology trade-offs.

- Demonstrate the technology in consideration of differing site conditions to measure its versatility.

- Evaluate process waste and the environmental consequences of use of the technology from start to finish.

- Address effects of multiple contaminants, especially radioactive contaminants, in the demonstrations.

- Assess operational readiness of the technology.

- Plan for unintended consequences and test all potential failure control mechanisms.

- Demonstrate that future cleanup will not be foreclosed by using the technology.

- Involve credible third-party evaluators in assessing demonstration results.

Stakeholders at the other arid sites confirmed and supported these general objectives, adding points that supplemented those noted above. These points describe the kind of technologies or technology attributes that stakeholders indicated they will find appropriate for deployment. Taken together with Hanford's stakeholder objectives, these points create the framework within which stakeholders will decide the acceptability of remedial technologies. Although these views have been generalized from a number of individual interviews and may not represent all stakeholders' views, remedial project managers and others responsible for technology deployment will want to take these perspectives into account in selecting technologies:

- Stakeholders prefer that technologies destroy contamination on site as opposed to concentrating contaminants for off-site transport and destruction.

- Stakeholders oppose using technology merely to transfer contamination from one environmental medium to another. For example, stakeholders are consistently concerned about moving contaminants from earth or water into air.

- Stakeholders recommend that technologies work with as few steps as possible. 
- Stakeholders prefer technologies that can be operated and maintained by existing staff. Stakeholders wish to avoid the need to call in distant experts for operation or to repair equipment.

- Stakeholders want technologies to be economical, simple, understandable, and robust.

- Technologies must be able to deal with co-contaminants. In order to be accepted for deployment, a technology must be effective with more than just one target pollutant. Acceptable technologies at DOE facilities must have the ability to deal with radioactive co-contaminants. Some stakeholders see the inability to do so as a "showstopper."

- A technology's entire treatment system matters to stakeholders. They evaluate the entire system, not just the most visible, active, or highly technical component. The entire system must be maintainable and economical. Secondary waste from each component of the technology's system must be safely manageable.

\section{SITE-SPECIFIC DEMONSTRATION ISSUES}

Certain site-specific concerns will also determine the deployability of technologies. Although the specific details of these concerns vary from site to site, the themes and requirements apply broadly.

- Technologies will be evaluated within the regulatory framework prevailing at a particular site. To enhance a technology's acceptability, the technology and its demonstration must be presented in terms of that site's specific regulatory framework. Applicable regulations vary among states and tribal nations. For example, in New Mexico, some tribal governments have more stringent cleanup standards than state government. Also in New Mexico, RCRA regulations are seen to govern technology demonstration and deployment at DOE sites.

- Where a natural resource is considered special, impacts on that resource may serve as an overriding factor in determining a technology's evaluation and acceptance. For example, water is extremely important to stakeholders in the arid west. Some communities in the Southwest are discovering that the quantity of available ground water is significantly less than previously estimated. Therefore technologies that do not involve removal and reinjection of ground water are regarded favorably. In another example, the Snake River Plain Aquifer in southern Idaho is of such economic, cultural, and political importance that any proposed technology's impacts on it will take precedence in the evaluation of that technology. Similarly Southwestern stakeholders prize the clarity of their air, and therefore will carefully scrutinize any proposed technology's possible air emissions.

- Remote sites place special requirements on technologies. These include the ability to withstand vandalism, and to operate reliably and automatically for long periods. Remoteness raises the question of power supply, an issue involving concerns about the negative impacts of needed power lines or the air emissions from generators. 
- The ability to operate in locally prevailing weather will determine the acceptability of technologies. Extremes of temperature and humidity, high winds, and deep snow are among the conditions that must be taken into account.

- Tradeoffs among criteria will vary from site to site. Local conditions will determine how stakeholders weigh the benefits and drawbacks of a technology's characteristics in relation to its capabilities.

- Versatility applies to all criteria, not just to performance. To be acceptable, a technology must be versatile and adaptable in terms of all the criteria used to evaluate it. For example, regulatory compliance acceptability can mean different things in different states.

\section{ACTUAL STATE-SPECIFIC ISSUES IDENTIFIED DURING STAKEHOLDER INTERVIEWS}

In addition to the common themes and supporting examples summarized above, stakeholders at the other arid sites provided site-specific inputs that illustrate the importance of defining technology acceptability objectives for deployment in those locations. Comments tended to fall into categories that the ID team has called natural factors, regulatory and policy factors, and contaminant factors. Table 1 below summarizes site-specific issues identified during the interviews. 
STATE-SPECIFIC ISSUES IDENTIFIED DURING STAKEHOLDER INTERVIEWS

\begin{tabular}{|c|c|c|c|}
\hline STATE & NATURAL FACTORS & REGULATORY AND POLICY FACTORS & CONTAMINANT FACTORS \\
\hline Colorado & $\begin{array}{l}\text { 1. Rocky, heterogeneous soils must be taken into } \\
\text { account in technologies' demonstrations in } \\
\text { order to have sufficient information to } \\
\text { evaluate acceptability in Colorado. } \\
\text { 2. The relatively shallow ground water at the } \\
\text { Rocky Flats site reduces some of the } \\
\text { advantages associated with in-situ } \\
\text { technologies. } \\
\text { 3. High winds and severe winter conditions must } \\
\text { be accounted for in technologies' } \\
\text { demonstrations in order to provide } \\
\text { information sufficient to evaluate acceptability } \\
\text { in Colorado. }\end{array}$ & $\begin{array}{l}\text { 1. Both RCRA and CERCLA apply to remediation at the } \\
\text { Rocky Flats Site and elsewhere in Colorado. Both } \\
\text { programs must be accounted for, and issues that address } \\
\text { regulatory needs of both laws should be incorporated } \\
\text { into test plans. } \\
\text { 2. Limited hazardous and mixed waste storage space and } \\
\text { time constraints are significant factors at Rocky Flats. } \\
\text { Consequently, technologies that produce little or no } \\
\text { process waste requiring storage are greatly preferred. } \\
\text { 3. Stakeholder values are extremely diverse in Colorado, } \\
\text { creating a difficult environment for predicting } \\
\text { acceptance of new technologies. } \\
\text { 4. Programmatic requirements to accelerate Rocky Flats } \\
\text { cleanup to meet specific target dates have constrained } \\
\text { the timeframe in which decisions on remediation } \\
\text { technologies must be made. Consequently, technologies } \\
\text { which have been fully demonstrated within the next } 12 \\
\text { to } 18 \text { months may be the only ones that will be } \\
\text { candidates for selection at Rocky Flats. }\end{array}$ & $\begin{array}{l}\text { 1. Plutonium co-contamination in soil is of } \\
\text { particular concern to many stakeholders at the } \\
\text { Rocky Flats Site. Materials-handling } \\
\text { technologies which may create airborne } \\
\text { plutonium contamination are regarded with } \\
\text { disfavor. } \\
\text { 2. Some stakeholders see a pressing need for } \\
\text { technologies that deal with particulates } \\
\text { (especially airborne radioactive particulates). } \\
\text { 3. Variable but relatively low concentrations of } \\
\text { vOCs (low ppms to ppb range) in ground water } \\
\text { and the vadose zone are the prevailing } \\
\text { conditions at Rocky Flats, and technologies that } \\
\text { function under these conditions (as well as low } \\
\text { flow rates) are most desirable. }\end{array}$ \\
\hline
\end{tabular}


STATE-SPECIFIC ISSUES IDENTIFIED

DURING STAKEHOLDER INTERVIEWS

\begin{tabular}{|c|c|c|c|}
\hline STATE & NATURAL FACTORS & REGULATORY AND POLICY FACTORS & CONTAMINANT FACTORS \\
\hline Idaho & $\begin{array}{l}\text { 1. The Snake River Plain Aquifer is considered } \\
\text { the single most important natural resource in } \\
\text { southern Idaho; consequently, treatment } \\
\text { technologies that have minimal negative } \\
\text { impact and withdraw as little water as } \\
\text { possible from it are more positively regarded. } \\
\text { 2. Severe cold temperatures and snow are } \\
\text { important factors for demonstrating } \\
\text { technologies for use in Idaho. }\end{array}$ & $\begin{array}{l}\text { 1. CERCLA is the principal regulatoiy program at INEL; } \\
\text { however other applicable, relevant and appropriate } \\
\text { requirements (ARARs) and certain captive operations } \\
\text { bring RCRA regulations to bear. In order to achieve } \\
\text { expeditious clean up, technologies that trigger more } \\
\text { prescriptive RCRA regulations are not preferred. } \\
\text { 2. Transportation of hazardous materials over tribal lands } \\
\text { is regulated by tribal law, which is enforced by tribal } \\
\text { police. Minimization of this type of transportation is } \\
\text { regarded as positive and technologies that do not require } \\
\text { the transportation of hazardous material have an } \\
\text { advantage. } \\
\text { 3. Tribal perspectives on cultural and archaeological } \\
\text { resources differ from European-derived perspectives. } \\
\text { Tribal stakeholders prefer technologies that disrupt } \\
\text { cultural resources as little as possible. }\end{array}$ & $\begin{array}{l}\text { 1. Radioactive co-contaminants are "show stoppers" } \\
\text { for any new technology at INEL. The inability } \\
\text { to address the radioactive component of mixed } \\
\text { waste will cause a technology (or technology } \\
\text { system) to be deemed unacceptable. }\end{array}$ \\
\hline
\end{tabular}


STATE-SPECIFIC ISSUES IDENTIFIED DURING STAKEHOLDER INTERVIEWS

\begin{tabular}{|c|c|c|c|}
\hline STATE & NATURAL FACTORS & REGULATORY AND POLICY FACTORS & CONTAMINANT FACTORS \\
\hline New Mexico & $\begin{array}{l}\text { 1. Deep ground water ( } 800^{\prime} \text { to } 1000^{\prime} \text { below the } \\
\text { surface) and lack of substantial contamination } \\
\text { at that depth at the two New Mexico DOE } \\
\text { sites result in little interest in ground-water } \\
\text { treatment technologies at those sites. } \\
\text { However, there is other ground-water } \\
\text { contamination in New Mexico, specifically } \\
\text { from nitrates, and stakeholders have concerns } \\
\text { with respect to technology use in these other } \\
\text { cases. } \\
\text { 2. New Mexico residents have recognized that } \\
\text { ground water is limited and that many areas } \\
\text { are contaminated with domestic and } \\
\text { agricultural waste. This has caused great } \\
\text { concern about cleaning this resource (ground } \\
\text { water) in place and wasting none. } \\
\text { 3. The special value placed on air quality and } \\
\text { expansive scenic vistas in New Mexico raised } \\
\text { extensive concerns with respect to air } \\
\text { emissions and any additional power lines or } \\
\text { other view-obscuring elements. } \\
\text { 4. The remote nature of many contaminated sites } \\
\text { raised concerns about vandalism and the } \\
\text { ability of technologies to be resistant to } \\
\text { tampering and operable without constant } \\
\text { attention. }\end{array}$ & $\begin{array}{l}\text { 1. RCRA (regulations and program culture) is the } \\
\text { exclusive regulatory influence over the two New } \\
\text { Mexico sites. All technologies must be demonstrated in } \\
\text { light of RCRA TSDF permitting requirements. RCRA } \\
\text { requirements can be extremely specific and are not } \\
\text { always risk-based. } \\
\text { 2. Certain tribal nations have imposed even more strict } \\
\text { environmental regulations than the federal government, } \\
\text { the state, or localities (e.g., wastewater discharge } \\
\text { requirements). Demonstration and deployment in } \\
\text { tribally controlled locations must take these } \\
\text { requirements into account. } \\
\text { 3. The ability of existing public works and maintenance } \\
\text { staff to operate and maintain new technology was } \\
\text { regarded as desirable. (Implies that simple, robust } \\
\text { technologies are preferred.) } \\
\text { 4. The ability to recoup the cost of remediation by } \\
\text { property liens and/or taxing was regarded as desirable. } \\
\text { (Implies that lower total technology cost is desirable.) }\end{array}$ & $\begin{array}{l}\text { 1. Nitrate contamination of ground water in many } \\
\text { locations raised questions and concerns about the } \\
\text { applicability of treatment technologies to this } \\
\text { contaminant. } \\
\text { 2. Non-DOE Superfund and state cleanup sites with } \\
\text { ground-water and vadose-zone contamination } \\
\text { exist in New Mexico. Chlorinated solvents and } \\
\text { petroleum hydrocarbon contaminants were most } \\
\text { frequently mentioned by stakeholders as } \\
\text { requiring new and better treatment technologies. }\end{array}$ \\
\hline
\end{tabular}


STATE-SPECIFIC ISSUES IDENTIFIED

DURING STAKEHOLDER INTERVIEWS

\begin{tabular}{|c|c|c|c|}
\hline STATE & NATURAL FACTORS & REGULATORY AND POLICY FACTORS & CONTAMINANT FACTORS \\
\hline Washington & $\begin{array}{l}\text { 1. The proximity to contaminated areas of the } \\
\text { Columbia River and its associated resources } \\
\text { creates special and potentially unique stakeholder } \\
\text { concerns. } \\
\text { 2. Hanford's glacial and outwash soils and relatively } \\
\text { deep ground water are rare, and test plans should } \\
\text { account for varying soil and ground-water } \\
\text { conditions at other sites. } \\
\text { 3. Large-scale problems (in terms of amount of } \\
\text { contamination and areal distribution) are common } \\
\text { at Hanford. Technologies that have potential for } \\
\text { large- volume and large-area cleanup are most } \\
\text { favored. } \\
\text { 4. Natural habitat may restrict technology } \\
\text { applications at certain locations at Hanford. }\end{array}$ & $\begin{array}{l}\text { 1. The Tri-Party Agreement (DOE/EPA/Washington } \\
\text { State) with its incorporation of CERCLA, RCRA, } \\
\text { and state regulations and associated site-specific } \\
\text { time requirements, creates a regulatory framework } \\
\text { that is unique. Technology demonstrations should } \\
\text { be aware of and incorporate sufficient information } \\
\text { to satisfy all regulations. } \\
\text { 2. Time requirements (milestones) at Hanford may } \\
\text { not be applicable to or appropriate at other } \\
\text { facilities. } \\
\text { 3. Tribal treaty rights and cultural resources may } \\
\text { impose special requirements on demonstrations at } \\
\text { certain locations on the rraniord Site. }\end{array}$ & $\begin{array}{l}\text { 1. Extensive ground-water contamination with few } \\
\text { or no co-contaminants, specifically radioactive } \\
\text { constituents, are found at Hanford's } 200 \text { West } \\
\text { Area. This represents a relatively rare case at } \\
\text { large contaminated federal facilities. } \\
\text { Demonstrations should account for other } \\
\text { situations as well. } \\
\text { 2. Carbon tetrachloride is a relatively rare } \\
\text { contaminant and, therefore, technologies should } \\
\text { also be demonstrated with other VOCs and VOC } \\
\text { mixtures in mind. } \\
\text { 3. High-visibility, high-hazard radioactive } \\
\text { contamination sites such as the Single Shell } \\
\text { Waste Tanks at Hanford can cause stakeholder } \\
\text { concern to be less focused on other contamination } \\
\text { problems and can influence stakeholder priorities. } \\
\text { 4here is serious stakeholder distrust of failure } \\
\text { control mechanisms and accident response for } \\
\text { new technologies. }\end{array}$ \\
\hline
\end{tabular}




\subsection{INTRODUCTION}

\subsection{PURPOSE AND OBJECTIVES OF ARID SITES' STAKEHOLDER PARTICIPATION IN TECHNOLOGY EVALUATION}

A three-phased stakeholder participation program is under way to support the Volatile Organic Compounds Arid Site Integrated Demonstration (VOC-Arid ID), which is hosted at the Hanford Site in the Washington State. The U.S. Department of Energy's (DOE's) Office of Technology Development sponsors and directs the VOC-Arid ID. Its purpose is to develop and demonstrate new technologies for remediating carbon tetrachloride and other VOC contamination in soils and ground water. The objective is to demonstrate a promising technology once and, if results warrant, deploy it broadly across the DOE complex and in the private sector. Initial activities focused on Hanford Site stakeholders. Approximately 40 individuals worked with the ID team to develop criteria for evaluating innovative technologies (See Phase I Involvement for Potential Stakeholders of the VOC-Arid Integrated

Demonstration, BHARC-800/93/004, December 1992), and to apply those criteria to a number of demonstration technologies. The ID focus has now been broadened to include stakeholders from other arid DOE sites at which these new technologies may ultimately be deployed.

By involving stakeholders at the early stages of technology development, the ID has committed to incorporating stakeholder values and information needs into the demonstrations. Then, when the demonstrations are complete and performance data are available, the stakeholders will receive those results. With that information, stakeholders can assess the acceptability of the technologies for broader potential deployment to solve environmental problems throughout the DOE complex and at other VOC-contaminated sites. Stakeholders include regulatory agencies, Native American tribes and nations, representatives of environmental and civic interest groups, public officials, environmental industry users of technology, and private citizens.

Remediation technologies were grouped into two "systems" for review. The ground-water system included four complementary technologies: sonic drilling for gaining access to contamination zones, membrane separation treatment at the surface, in-well vapor stripping to clean ground water below the surface, and in-situ bioremediation using native microorganisms to destroy contamination in place. The soil remediation system consisted of two technologies: passive soil vapor extraction using borehole flux to remove contaminants in vapor form, and treating the extracted vapors at the surface with a technology called tunable hybrid plasma. Though any one of the technologies could be used alone or in other combinations, they were grouped into these systems to help participants conceive of the types of issues that would arise when combining technologies into a treatment train. Tunable hybrid plasma, as an example, is a treatment technology that could be used to treat VOC-contaminated air at the surface, regardless of the method used to extract the contamination.

The ID team began by seeking Hanford stakeholder participation and creating mechanisms for incorporating stakeholder input into the demonstrations. The process and results of involving Hanford stakeholders in review of the ground-water system have been documented in Phase II Stakeholder Participation in Evaluating Innovative Technologies: VOC-Arid Integrated Demonstration, Ground-water Remediation System (TTP Number RL 311101). Those 
activities included stakeholder review of information about the four ground-water system technologies, focus groups conducted to gain an understanding of stakeholder perspectives and information needs, preparation of focus group reports, and an all-participants' workshop to integrate the results into recommended input to the technology demonstration test plans. Hanford stakeholders also reviewed the two technologies that were grouped in a soil remediation system. That input is the subject of Hanford Stakeholder Participation in Evaluating Innovative Technologies: VOC-Arid Site Integrated Demonstration. Soil Remediation Technologies (February 1995).

To broaden the scope of input, the ID team consulted with stakeholders at other arid DOE sites where the technologies may someday be deployed. This report documents the involvement of stakeholders at four western DOE sites: Los Alamos National Laboratory and Sandia National Laboratories in New Mexico, Idaho National Engineering Laboratory in Idaho, and the Rocky Flats Site in Colorado. Staff from a fifth arid site, the Lawrence Livermore National Laboratory, were invited to be involved but chose not to participate at this time.

The VOC-Arid ID team worked with public participation and technical staff, including both environmental restoration and technology development personnel, and identified contacts at each site. Those contacts helped develop site-specific stakeholder involvement strategies and assisted the VOC-Arid ID team in identifying interested stakeholders and carrying out stakeholder consultation. Stakeholders were asked to review the evaluation criteria and a package of information on the six innovative technologies. They were then interviewed to gain their perspectives on the technologies.

This report describes the results of consultation with stakeholders from the four other arid sites. Together with Hanford stakeholder views on the six technologies, summarized here for comparison, this information provides valuable input to the development of technology test plans for the demonstrations. Though this report summarizes and integrates input from Hanford stakeholders in comparison with input from stakeholders at the other arid sites, it does not duplicate the wealth of information contained in the three earlier Hanford reports. Readers are referred to those reports for a full understanding of Hanford stakeholders' perspectives on the six technologies.

It should be noted that there were differences between the approaches used with the Hanford stakeholders and the stakeholders from the other arid sties. Hanford stakeholders were involved in a series of consecutive events over a two-year period, including face-to-face interviews, focus groups, workshops, and review of project reports, in addition to reviewing the profiles and fact sheets on the technologies. They thus benefitted from an in-depth consultation process, and their input reflected that longer-term commitment of time in the level of detail, completeness, and understanding of the technologies. The stakeholders from the other arid sites, however, had a relatively limited time to review the technology information, and were interviewed only once. They varied significantly in their levels of preparedness for the interviews. The input received, therefore, was quite variable, and cannot be compared in a quantitative analysis. The comparisons presented in this report are qualitative in nature, but serve to illuminate the similarities among stakeholder perspectives at 
all of the arid sites, and more important, the different and in some cases unique views and site-specific concerns.

If innovative technologies are to be demonstrated once and deployed broadly, it will be necessary for those demonstrations to take into account a broader set of stakeholder issues than just those of the demonstration host site, providing answers to questions raised by stakeholders at other locations of potential deployment. This report, and subsequent technology acceptance reports, will increase understanding of regional stakeholder similarities and differences. Through this information, it will also be possible to judge how broad and detailed a stakeholder involvement program is needed to evaluate potential stakeholder acceptance of a particular technology at a given site. Future stakeholder involvement programs can build on this information to understand the benefits of involving stakeholders at potential deployment sites as well as at demonstration host sites, and to gauge the degree of unique, site-specific input that is likely to be received.

When the demonstrations are completed, performance information will be provided to the stakeholders so that they can assess the acceptability for deployment of the demonstrated technologies. Their assessments will inform deployment decision makers about stakeholders' perceptions of proposed technologies. These assessments will enable decision makers to mitigate for concerns, and to evaluate the likelihood that their specific technologies will be accepted for deployment.

\subsection{REPORT ORGANIZATION}

This report is organized to document the activities conducted with arid site stakeholders in relation to six technologies to remediate VOC contamination. It incorporates summary-level Hanford stakeholder input to allow for comparison with input received at the other sites. Section 2.0 describes the methodology used to engage stakeholders in assessing the technologies, and describes how stakeholder input will be integrated into the demonstrations. Section 3.0 briefly describes the six technologies of interest. Section 4.0 provides the results of stakeholder input for each of the six technologies. Appendix A includes profiles and fact sheets for the six technologies. 


\subsection{STAKEHOLDER PARTICIPATION METHODOLOGY}

\subsection{OVERALL APPROACH TO STAKEHOLDER PARTICIPATION}

The VOC-Arid ID has encouraged the participation of stakeholders in the demonstration of innovative technologies in order to improve the decisions that DOE and its contractors make about technology development, demonstration, and deployment. The basic approach is to identify people and organizations with a stake in environmental cleanup at DOE sites, and therefore in the demonstration of innovative technologies. These people are invited to participate in ways that are convenient and meaningful to them, and are provided with substantive information about the technologies. Their input in identifying issues and concerns, defining the kinds of information needed from the demonstrations, and assessing the acceptability of the technologies for deployment, will help ensure that only broadly promising technologies receive continued funding from DOE for development. This approach is designed to increase the likelihood and rate of successful deployment of the new technologies needed to accomplish environmental restoration throughout the DOE complex and at private facilities. Conducting the process first at Hanford, then expanding it to other western sites, has allowed evaluation of differences and similarities among stakeholders' perspectives in different regions.

\subsection{SPECIFIC METHODOLOGY TO INVOLVE STAKEHOLDERS}

Seven steps were taken to involve stakeholders from the other arid sites in the VOC-Arid ID.

$\underline{\text { Step } 1}$

As a first step in involving stakeholders in evaluating the six innovative remediation technologies, the ID team prepared profiles for each technology. Because the profiles are lengthy, the team also prepared a brief fact sheet for each technology that describes the technology's need and function, objectives, advantages and disadvantages, and challenges. Copies of the fact sheets and profiles for the six technologies are included in Appendix A of this report.

$\underline{\text { Step } 2}$

The VOC-Arid ID team identified staff contacts at each of the five DOE arid sites other than Hanford to begin discussions about stakeholder involvement. Staff contacts were sought in both the stakeholder involvement area as well as among the environmental restoration and technology development staff. Preliminary discussions allowed the VOC-Arid ID team to describe its program and the types of assistance it would like from site personnel. The VOCArid ID team emphasized the importance of seeking input from site personnel and the critically important role of the site contacts. The site representatives stressed the need to understand site-specific organizations and activities, and to tailor a strategy for each site that was sensitive to that site's schedule, resources, and political realities. The ID team committed to coordinating closely with the site contacts to design and implement the site-specific strategies. 
In order to better understand the site-specific situations, two members of the VOC-Arid ID team visited each of the five other DOE arid sites. Meetings with site contacts were important to gain insights about their stakeholder involvement programs and how best to tailor the VOC-Arid ID stakeholder involvement approach at their sites. Other individuals identified by the site contacts, including DOE and contractor personnel and some external stakeholders, were interviewed to explain the ID stakeholder involvement initiative and to gain their input on how to proceed at that location. This reconnaissance information formed the basis for draft site-specific strategies, developed by the VOC-Arid ID team in conjunction with the site staff contacts. The strategies identified activities, stakeholder categories and names, timelines, and desired products.

\section{$\underline{\text { Step } 4}$}

Staff from four of the sites worked with the ID team to develop site-specific stakeholder involvement strategies. Staff from the fifth site, Lawrence Livermore National Laboratory, decided not to participate at this stage in the demonstration process, but to defer stakeholder involvement on the technologies until the demonstrations are complete and specific technologies are available for deployment at Livermore. The other four site representatives identified points of contact for coordination of the stakeholder outreach activities, and reviewed the lists of stakeholders to be contacted. The primary site-specific contacts were:

- Los Alamos National Laboratory -- Marja Shaner

- $\quad$ Sandia National Laboratories -- Steve Baca

- $\quad$ Rocky Flats -- Carla Sanda (EG\&G), Beth Brainard-Jordan (DOE)

- Idaho National Engineering Laboratory -- Reuel Smith (EG\&G), Connie Nash (DOE)

The approach in all four strategies was to include interviews with a cross section of stakeholders, representing technology users, regulatory agencies, Native American tribes, local government, and civic and environmental interest groups. Those interviews were to focus on reviewing the six technologies of interest and gaining stakeholder input on their issues, questions, and concerns related to those technologies. That input would define additional information needs to be filled by the technology demonstrations.

\section{$\underline{\text { Step } 5}$}

The VOC-Arid ID team then sent stakeholders a letter describing the objectives of stakeholder involvement in technology development and demonstration, and an overview description of the technology development and demonstration processes and the kinds of VOC contamination that is found at arid sites across the western states.

\section{$\underline{\text { Step } 6}$}

Stakeholders who received letters were then contacted by telephone and asked if they were willing to be interviewed. Stakeholders who agreed to be interviewed received a confirming 
letter and profiles and fact sheets for each technology for review prior to meeting with the ID team interviewers. They also received the set of technology evaluation criteria that was developed earlier by Hanford stakeholders.

\section{$\underline{\text { Step } 7}$}

In most cases, a two-person team conducted interviews during August and September 1994. Interviewers explained to the stakeholders at the four sites how this activity fits within the context of the VOC-Arid ID stakeholder involvement program. They answered stakeholders' questions about the technology profiles and the process, discussed how the evaluation criteria were being used to shape the technology test plans, and then proceeded to discuss the stakeholders' issues, concerns, questions about, and reactions to the technologies. Discussion focused on three questions:

- What do you consider important in choosing an environmental restoration technology? What additional information would you need to evaluate these candidate technologies with confidence?

- Are there aspects of these technologies that concern you?

- What features of the technologies do you see as advantages compared to cleanup technologies available today?

Stakeholder input was recorded, and clarifying questions were asked where needed to obtain complete and accurate documentation. Interviewers explained to participants that their input would be summarized in a report and used to develop technology test plans or, in the case of already-demonstrated technologies, used to interpret demonstration data and assess issues for deployment. Stakeholder input was summarized according to each category of technology evaluation criteria, and translated into recommended data requirements for each technology, as presented in Section 4.0. The comments themselves were forwarded to the principal investigators for the technologies for their consideration, as well as being aggregated for this report. 


\subsection{DESCRIPTION OF TECHNOLOGIES}

Stakeholders evaluated six technologies, which for purposes of discussion were divided into two systems. It should be noted, however, that each technology can be used independently, and, as an example, tunable hybrid plasma's application is not limited solely to remediating contamination in soil. The technologies are described briefly below, with Appendix A providing additional information.

\subsection{GROUND WATER REMEDIATION SYSTEM TECHNOLOGIES}

The four ground water remediation system technologies chosen for stakeholder review were:

- An access technology, sonic drilling

- A contaminant extraction system, in-well vapor stripping

- A surface treatment technology, membrane separation

- A method for treating contaminants in place, in-situ bioremediation

These technologies are described below.

\subsubsection{Sonic Drilling}

Sonic drilling represents a departure from traditional cable tool or other forms of drilling for reaching contamination in soil and ground water. The sonic drill uses counter-rotating weights to generate resonant sonic energy. This causes the drill pipe to vibrate along its entire length. The energy is transmitted down the drill pipe to the drill bit, creating a cutting action. The resonant energy causes surrounding soils to relax into the adjacent formation just enough to permit the drill pipe to move into the earth. Drill cuttings are pushed into the borehole wall, or collected as core samples inside the steel drill pipe. No drilling fluid is required in most soil types. Thus, relatively little secondary waste is generated. Sonic drilling is intended to be faster and better at controlling contamination than traditional drilling methods. It is designed to be an improved method of achieving high-quality samples in certain media (for example, by avoiding wetting media), and conducting directional drilling. Some demonstration of sonic drilling has occurred at Hanford, but there are plans to further demonstrate it at greater depths. Thus, stakeholder input to enhance the test plan still can and will be considered.

\subsubsection{In-Well Vapor Stripping}

In-well vapor stripping is a VOC removal system that volatilizes VOCs in ground water and draws them up inside the well to the surface as a vapor, which can then be treated. The system works somewhat like a fish tank filter system. It consists of a well within a well, where the inner well extends from the ground surface into the saturated zone and is screened (open) in the zone of contamination. The outer well extends through the unsaturated zone and may end above the water table. A gas injection line is placed in the inner well, and injects bubbles in the water in the well. The bubbles and water rise together. This column of water with bubbles then hits a packer and the bubbles burst. The air in the bubbles contains the VOCs from the ground water. The water falls down in the space between the inner and outer 
wells and is returned to the water table. The gas from the bubbles is vacuumed off through a vacuum line extending from the ground surface into the space between the inner and outer wells. In this way the VOC-laden vapor is extracted, and the partially cleaned water is returned to the aquifer. The system recirculates the ground water through air-lift pumping. The ground water becomes cleaner and cleaner with each pass though the system.

The postulated advantage of this system over the baseline method is that VOCs can be removed from ground water without pumping the water to the surface. Contaminated water does not need to be handled, stored, or disposed of above ground, and expensive injection wells are not needed. The demonstration must show that ground water can be successfully diverted from the well back into the saturated zone. Furthermore, the zone of influence (which will be measured) needs to be great enough to make the technology cost effective. Potential chemical changes in the ground water or soil contamination levels or characteristics may also occur, and monitoring methods must be examined.

\subsubsection{Membrane Separation}

The membrane separation technology treats VOCs from gas streams at the surface, using a high-pressure system. A stream of contaminant-laden air, removed from the ground using vacuum extraction, is compressed and sent to a condenser. There the liquid solvent (e.g., carbon tetrachloride) is recovered. Condenser stream goes to the membrane module for further concentration. The membrane module is made up of a thin-film membrane wound around a collection pipe. These membranes further concentrate the air stream as it passes through them twice. The system is estimated to remove 95 percent of VOC vapors before the remainder pass through a granular activated carbon (GAC) canister to complete the VOC capture. This technology is postulated to be less expensive than GAC, which is the baseline, and more effective for high-concentration VOC gas streams. Though membrane separation has already been demonstrated at Hanford, it was included here as an integral part of the ground-water technology system. Stakeholder input will be helpful as deployment decision makers consider use of membrane separation in remediation.

\subsubsection{In-Situ Bioremediation}

In-situ bioremediation involves stimulating naturally occurring organisms in ground water so that they degrade and detoxify chemical contamination. Native microorganisms are stimulated by the addition of nutrients to the water. They then consume and degrade carbon tetrachloride. The in-situ bioremediation process injects acetate and nitrate (as needed after initial nitrate levels are depleted) through a series of injection wells. The injected nutrients produce a zone of active organisms around the well. This technology can be used as a sole cleanup technology or as a polishing technology to remove the last small amounts of aquifer contamination. The advantage of the technology, to be tested in demonstration, is its ability to destroy VOCs in place, rather than pumping the ground water to the surface. This may reduce the time and cost of cleanup, if the technology functions as predicted. Factors to be tested in the demonstration include the ability to reduce soil permeability, thereby restricting the rate of movement of VOCs; reduced costs as compared to pump and treat methods; and 
decreased worker exposure to contaminants. The demonstration must prove the capability for effective delivery and mixing of nutrients, control of excessive microbial growth, and adequate monitoring.

\subsection{SOIL REMEDIATION SYSTEM TECHNOLOGIES}

Two soil remediation technologies to be demonstrated were selected for stakeholder review; they are:

- An extraction technology, passive soil vapor extraction

- An above-ground treatment technology, tunable hybrid plasma

These technologies are described below.

\subsubsection{Passive Soil Vapor Extraction Using Borehole Flux}

This technology takes advantage of the natural phenomenon of atmospheric pressure change. Fluctuations in atmospheric pressure occur due to weather and seasonal changes, creating differential pressure between the atmosphere and air contained in vadose zone soils. Contaminants are carried by air flow to the surface as pressure changes from high to low. This process is accelerated when the subsurface is connected directly by a well or borehole to the surface. With an understanding of the pressure relationship between the surface and subsurface at a given site under various atmospheric conditions, the pathways (e.g., boreholes or wells) can be installed and managed to enhance contaminant removal. Enhancements to the natural phenomenon may include devices at the surface such as turbines or windmills, one-way flow valves to control air flow direction through the borehole, injection of hot air or steam, and well networks. VOCs may be captured at the surface on GAC or treated by various processes.

\subsubsection{Tunable Hybrid Plasma}

This technology is applied above ground. A moderate-energy electron beam is directed into a flow of air containing organic contaminants. The electron beam is produced by applying electricity to a linear filament electron source in a vacuum chamber. The primary electrons that are generated pass through a titanium foil window. These primary electrons create several thousand secondary electrons with lower energy levels than the primary electrons. The secondary electrons rapidly cool to room temperature and attach to halogenated hydrocarbon (VOC) molecules in the waste stream. This causes the VOC molecules to dissociate into simpler molecules, effectively being destroyed. Carbon tetrachloride and TCE are preferentially destroyed because of the way their molecules are arranged. The end products of the process are carbon dioxide, water, oxygen, nitrogen, hydrochloric acid, and chlorine gas. Further treatment in a conventional liquid/air scrubber reduces the secondary wastes to salt. 


\subsection{SUMMARY OF STAKEHOLDER INTERVIEW RESULTS}

\subsection{SUMMARY OF STAKEHOLDER INPUT}

Seventy-five stakeholders were interviewed at the four sites, including:

- Los Alamos National Laboratory -- 21 people

- Sandia National Laboratories -- 20 people

- $\quad$ Rocky Flats Plant -- 18 people

- Idaho National Engineering Laboratory -- 16 people

These individuals represent a cross section of stakeholders with an interest in technology development and demonstrations and environmental remediation at DOE sites, including regulators, Native American tribes, civic and environmental interest groups, local officials, and technology users (DOE, contractors, and industry). Whenever possible, interviewers sought stakeholders' input on all six technologies. Interviewers answered stakeholder questions about the technologies, clarified information from the profiles, and discussed the stakeholders' perspectives on issues and information needs concerning each technology.

Because of the wide range of types of stakeholders interviewed, and their varying familiarity with the DOE environmental restoration program and technology development initiatives, the interviewers received diverse comments on the six technologies. Comments were provided to the principal investigators for the technology demonstrations so that they can be addressed wherever possible in both the demonstration phase and in deployment decision making. In this way, the integrated demonstration can respond to stakeholders' issues and concerns.

Stakeholders from each of the arid sites, including Hanford, were divided into five categories, depending on their affiliations:

- Regulatory agency personnel, including federal, state, and local agencies

- Native American tribal representatives

- Interest groups, ranging from environmental and "watchdog" groups to business and homeowners' associations

- Technology users, including DOE and contractor personnel with responsibility for environmental restoration

- Public officials, including federal, state and local elected and appointed positions

This section summarizes comments from all categories of stakeholders interviewed at the four sites. Comments have been grouped for analysis into a set of primary technology evaluation 
criteria developed by Hanford stakeholders early in the stakeholder involvement process (See Phase I Involvement for Potential Stakeholders of the VOC-Arid Integrated Demonstration, BHARC-800/93/004, December 1992). Those criteria are shown in Figure 1 on the following page, and include:

- Performance (For stakeholder discussion, this category was broken down into remaining contamination, process waste, practicality, and whether the technology works as intended.)

- Cost

- Time

- Worker safety

- Public health and safety

- Environmental impacts

- $\quad$ Public perception

- Tribal rights and future land uses

- Socio-Economic interests

- $\quad$ Compatibility with cleanup milestones

- $\quad$ Regulatory infrastructure and track record

- Regulatory compliance

The following subsections summarize input received from Hanford stakeholders about each of the six technologies, and compare it with comments from the other arid sites. The primary focus here is to capture the themes common to all sites, and to note differences between sites/regions and between different types of stakeholders.

\subsection{SONIC DRILLING}

Stakeholders raised a range of issues related to the demonstration and potential deployment of sonic drilling. Input from Hanford stakeholders is provided in detail in the two reports cited earlier. Principal concerns of Hanford stakeholders about sonic drilling revolved around its practicality, including issues of reliability and performance; whether it would work as well as projected; and its cost relative to other drilling techniques. Few issues were raised about environmental impacts.

Stakeholders at the other arid sites provided more frequent and detailed comments on sonic drilling than those at Hanford. This may reflect a greater familiarity and comfort level with sonic drilling at Hanford, where it is being demonstrated. It may also reflect concern about possible impacts on ground water, the quantity and quality of which are overriding concerns in many arid western states. In analyzing the comments received in each criterion category, the following similarities and differences are noted.

\section{$\underline{\text { Remaining Contamination }}$}

No comments were received on remaining contamination, as sonic drilling is not a treatment or remediation technology. 


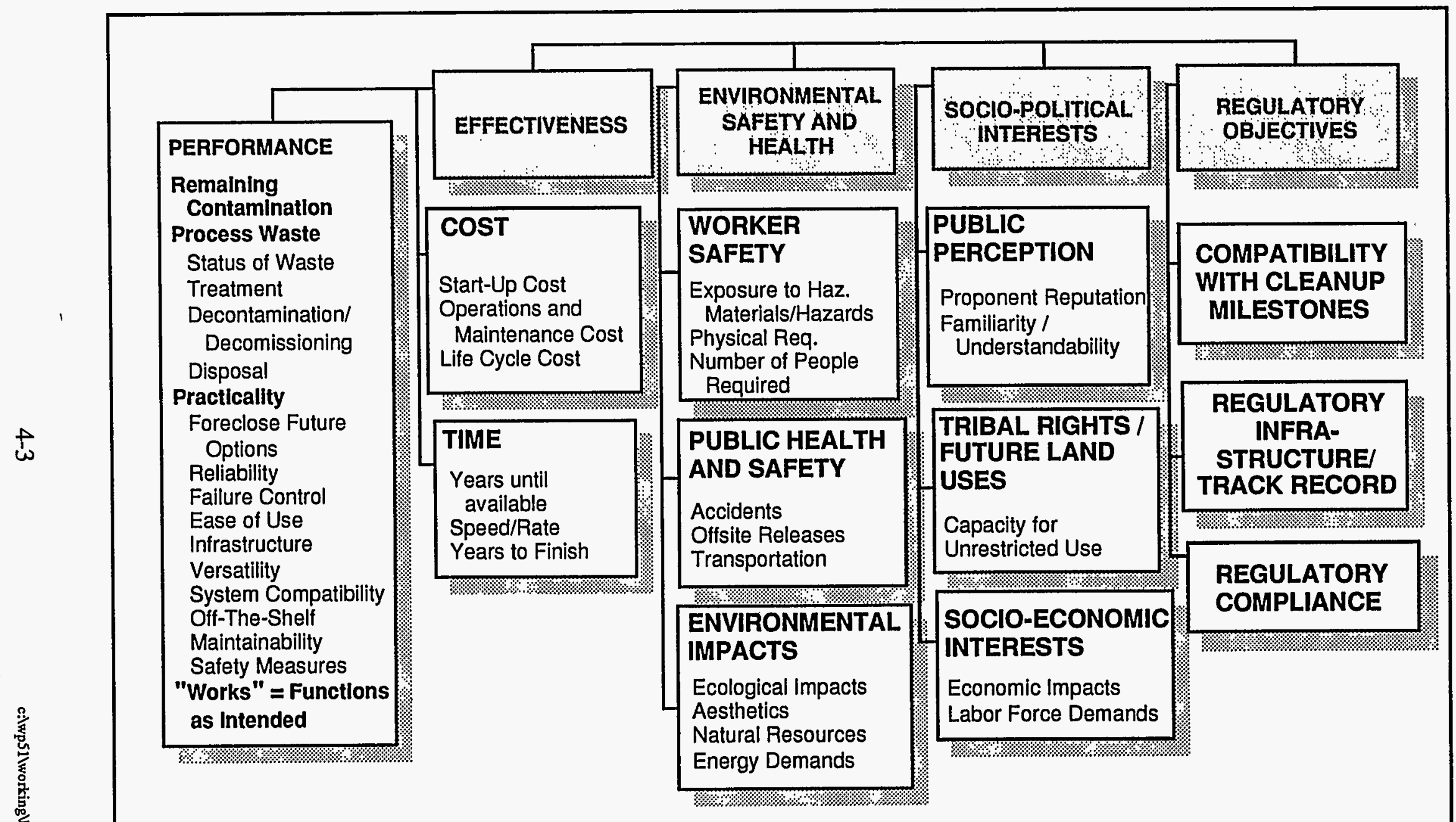

Figure 1. Technology Evaluation Criteria Developed by Stakeholders 


\section{Process Waste}

Hanford stakeholders identified as a significant advantage sonic drilling's ability to operate without drilling fluids, thus producing little process waste. Stakeholders at the other sites echoed this, with an INEL technology user adding that drilling fluid can potentially move contamination, making sonic drilling even more advantageous.

\section{Practicality}

Hanford stakeholders emphasized the evaluation of sonic drilling's practicality, and how its operation may affect characterization samples to provide representative cores of specified size and composition. The ability to do full-spectrum characterization during drilling was important, especially to regulators. Operating limits in a range of geologic media were of interest, as was the ability for angled drilling. Stakeholders said they wanted information about how large a borehole was possible to drill with the technology. Appropriate soil types must be defined as well. Stakeholders requested data on temperatures at the drill head, and effects on VOC measurements in retrieved samples. Functional reliability should be defined in terms of time between breakdowns, availability of replacement parts, and maintenance. Drill pipe failure should be carefully evaluated and quantified.

Stakeholders from the other sites raised additional issues about reliability of the technology (e.g., evaluation of drill pipe fatigue at greater depths). They requested additional operating limit information related to the ability to cut through boulders and other hard rock media, to operate at great depths (e.g., up to 800 feet at Los Alamos), to drill on pattern around obstructions, to operate in caliche layers, and to provide reliable non-cased boreholes as used primarily in New Mexico.

Another area of concern at the other sites was the effect of using sonic drilling. Effects on measurements of hydraulic conductivity and other geologic information after the sonic method packed cuttings into the formation was raised as a concern, as was the ability to "lose" sedimentary interbeds in basalt. Stakeholders raised issues about the effects of vibration on the earth (e.g., seismicity), on packing material used to seal the tops of screened borehole intervals, and on nearby structures. Baseline drilling technologies varied from Hanford; Los Alamos suggested comparison with hollow-stem auger drilling, and INEL and Rocky Flats use rotary drilling, not cable tool. Stakeholders also suggested dual-wall reverse-circulation percussion-hammer drilling as a comparison.

\section{Works as Intended}

Hanford questions about whether sonic drilling will function as intended related primarily to the diameters of boreholes it is capable of drilling. Other sites added questions about the ability to drill in an aquifer, potential effects of water on effectiveness (it was surmised that it could dampen the vibration and slow the drilling), and alteration of the chemical or physical nature of contaminants in the samples in ways that may lead to mischaracterization of samples. 


\section{Cost}

Hanford stakeholders wanted to see thorough cost comparisons with the baseline technology, cable tool drilling, including the effects of drill pipe failure. Costs should include capital, operating, maintenance, repair, downtime, training, and all other costs. Stakeholders at the other arid sites concurred, also suggesting additional baseline drilling techniques for comparison.

\section{Time}

Hanford stakeholders addressed the time required to use sonic drilling. Stakeholders at other sites suggested comparing the speed of drilling and the overall time needed to complete the job, in comparison with the other baseline technologies.

\section{Worker Safety}

A few concerns were raised by Hanford stakeholders about worker safety in relation to sonic drilling. Worker safety performance during the demonstration (e.g., days lost, injury accidents, exposure records) should be compared with the baseline technology. Release of volatilized VOCs at the wellhead is a concern that requires monitoring. As with cable tool drilling, volatilized VOCs need to be captured. Two stakeholders from other sites indicated a preference for angled drilling so that workers did not need to drill directly through waste areas, drums, etc. This was noted as a particular advantage at Sandia's mixed-waste landfill. Another comment related to the potential for automating the drill operation to reduce labor requirements and avoid worker hearing damage.

\section{Public Health and Safety}

No specific comments on public health and safety were received from Hanford stakeholders in relation to sonic drilling, but at INEL an interest group representative suggested evaluating the feasibility of capturing off gas if contaminants are encountered while drilling. At Rocky Flats, an interest group representative suggested that plutonium-contaminated dust could be associated with subsurface air, and questioned potential health and safety impacts as well as environmental impacts.

\section{Environmental Impacts}

Hanford stakeholders perceived sonic drilling as equivalent to its baseline in terms of environmental health and safety. Noise levels, however, need to be measured and compared with the baseline. Effects of vibration on nearby structures and activities will also be important to measure. Stakeholders at the other sites, in addition, raised issues of noise impacts, vibration effects on geological structures and cultural resources, aesthetic impacts, and the potential for opening contaminant pathways to deeper zones. 


\section{$\underline{\text { Public Perception }}$}

No specific public perception comments were received at Hanford or elsewhere. An interest group representative at INEL believed that a reasonable monitoring system for sonic drilling would be an asset to public confidence.

\section{Tribal Rights and Future Land Uses}

Stakeholders provided no specific comments in this category, though a public official at Los Alamos suggested that Native American tribes may object to a noisy, vibrating assault on the earth.

\section{$\underline{\text { Socio-Economic Interests }}$}

The skill levels and training needed for sonic drilling operators were a question at Hanford and elsewhere.

\section{Compatibility with Cleanup Milestones}

Hanford stakeholders suggested determining how use of sonic drilling would affect the rate of overall cleanup in comparison with regulatory commitments and milestones. There were no specific comments on this category from the other arid sites.

\section{$\underline{\text { Regulatory Infrastructure/Compliance }}$}

No comments were received at Hanford about the regulatory framework. A New Mexico regulator indicated that the technology is unproven, and would need clear examples of its benefits to be permitted. Dust control, in compliance with EPA's NESHAPS regulations, will also be an issue in New Mexico.

Table 1 on the following pages summarizes comments on sonic drilling from stakeholders at the other arid sites, organized by criterion category. 


\begin{tabular}{|c|c|c|}
\hline ISSUES BY CATEGORY & $\begin{array}{l}\text { SITES WHERE ISSUES } \\
\text { RAISED }\end{array}$ & $\begin{array}{l}\text { STAKEHOLDER } \\
\text { CATEGORIES }\end{array}$ \\
\hline \multicolumn{3}{|l|}{ Process Waste } \\
\hline $\begin{array}{l}\text { The ability of sonic drilling to operate } \\
\text { without drilling fluids, thus reducing } \\
\text { secondary waste, is an advantage. }\end{array}$ & $\begin{array}{ll}- & \text { INEL } \\
- & \text { Rocky Flats } \\
\text { - Sandia }\end{array}$ & $\begin{array}{ll}- & \text { Technology User } \\
\text { - } & \text { Regulator } \\
& \text { Interest Group } \\
& \text { Technology User }\end{array}$ \\
\hline $\begin{array}{l}\text { Sonic drilling brings less drilling } \\
\text { media and subsurface material to the } \\
\text { surface than other methods; this is an } \\
\text { advantage. }\end{array}$ & Rocky Flats & Regulator \\
\hline \multicolumn{3}{|l|}{ Practicality } \\
\hline $\begin{array}{l}\text { Define the range of conditions in } \\
\text { which this technology is effective, } \\
\text { including the effectiveness of the } \\
\text { technology in different geologic media, } \\
\text { in heterogeneous soils, and at } \\
\text { different depths. }\end{array}$ & $\begin{array}{l}\text { - } \quad \text { INEL } \\
\text { - } \quad \text { Los Alamos } \\
\text { - } \quad \text { Rocky Flats } \\
\text { - } \quad \text { Sandia }\end{array}$ & \begin{tabular}{|ll}
$\cdot$ & Regulator \\
& Technology User \\
$-\quad$ & Interest Group \\
Technology User \\
- \\
Regulator \\
Technology User \\
- \\
Regulator \\
Interest Group
\end{tabular} \\
\hline $\begin{array}{l}\text { Assess the ability to drill on pattern, to } \\
\text { handle large obstructions, to drill at } \\
\text { different rates, to drill through a cased } \\
\text { hole, to install instrumentation down- } \\
\text { hole, to drill around corners, and to } \\
\text { perform angled or directional drilling. }\end{array}$ & $\begin{array}{ll}- & \text { INEL } \\
\text { - } & \text { Los Alamos } \\
\text { - } & \text { Sandia } \\
& \text { - } \quad \text { Rocky Flats }\end{array}$ & \begin{tabular}{|ll}
- & Regulator \\
& Technology User \\
- & Technology User \\
- & Regulator \\
- & Technology User \\
Technology User
\end{tabular} \\
\hline $\begin{array}{l}\text { Provide a more definitive evaluation of } \\
\text { reliability, including the reliability of } \\
\text { drill pipes, and methods for } \\
\text { improvement. Assess the rate of } \\
\text { equipment failure and provide } \\
\text { quantitative results. }\end{array}$ & $\begin{array}{ll}- & \text { INEL } \\
\text { - } & \text { Los Alamos } \\
\text { - } & \text { Sandia }\end{array}$ & \begin{tabular}{|l} 
- Interest Group \\
- \\
Technology User \\
Technology User \\
Interest Group \\
Regulator \\
Technology User
\end{tabular} \\
\hline
\end{tabular}




\begin{tabular}{|c|c|c|c|}
\hline & ISSUES BY CATEGORY & $\begin{array}{l}\text { SITES WHERE ISSUES } \\
\text { RAISED }\end{array}$ & $\begin{array}{l}\text { STAKEHOLDER } \\
\text { CATEGORIES } \\
\end{array}$ \\
\hline - & $\begin{array}{l}\text { Ensure that non-petroleum based } \\
\text { drilling lubricants (e.g., vegetable oil) } \\
\text { are used to avoid volatilizing } \\
\text { petroleum-based lubricants and causing } \\
\text { contamination. }\end{array}$ & Rocky Flats & Regulator \\
\hline - & $\begin{array}{l}\text { Assess temperatures of a retrieved core } \\
\text { at the point of retrieval, the } \\
\text { temperature of the drill bit, depending } \\
\text { on material of bit and soil types, and } \\
\text { the potential effects of elevated } \\
\text { temperatures on chemical and physical } \\
\text { characterization accuracy. }\end{array}$ & $\begin{array}{ll}- & \text { Los Alamos } \\
- & \text { Rocky Flats } \\
\text { - } & \text { Sandia }\end{array}$ & $\begin{array}{l}\text { Technology User } \\
\text { Technology User } \\
\text { Interest Group } \\
\text { Public Official } \\
\text { Technology User }\end{array}$ \\
\hline$\cdot$ & $\begin{array}{l}\text { Compare sonic drilling to other } \\
\text { drilling methods, including hollow- } \\
\text { stem auger and air rotary drilling. }\end{array}$ & $\begin{array}{ll}- & \text { INEL } \\
- & \text { Los Alamos } \\
- & \text { Rocky Flats }\end{array}$ & $\begin{array}{ll}\text { - } & \text { Technology User } \\
\text { - } & \text { Technology User } \\
\text { - } & \text { Technology User }\end{array}$ \\
\hline - & $\begin{array}{l}\text { Evaluate sonic drilling's ability to } \\
\text { work in conjunction with the cone } \\
\text { penetrometer and the SeaMist } \\
\text { technologies. }\end{array}$ & Sandia & Technology User \\
\hline$\cdot$ & $\begin{array}{l}\text { Explore the potential for explosion or } \\
\text { catastrophic failure. }\end{array}$ & Sandia & Interest Group \\
\hline$\cdot$ & $\begin{array}{l}\text { Assess how uncased borehole walls } \\
\text { hold up with sonic drilling in various } \\
\text { soil types. }\end{array}$ & Sandia & Technology User \\
\hline$\cdot$ & $\begin{array}{l}\text { Assess the effects of sonic drilling's } \\
\text { vibration on nearby well's packing } \\
\text { material used to seal the tops of } \\
\text { screened intervals. }\end{array}$ & Los Alamos & Tribes \\
\hline - & $\begin{array}{l}\text { Evaluate other available sources for } \\
\text { the technology; there appears to be a } \\
\text { single vendor. }\end{array}$ & Sandia & Technology User \\
\hline - & $\begin{array}{l}\text { Evaluate the effectiveness of sonic } \\
\text { drilling in characterizing old landfills } \\
\text { and drainfield areas by angle drilling. }\end{array}$ & Sandia & Regulator \\
\hline
\end{tabular}




\begin{tabular}{|c|c|c|}
\hline ISSUES BY CATEGORY & $\begin{array}{l}\text { SITES WHER E ISSUES } \\
\text { RAISED }\end{array}$ & $\begin{array}{l}\text { STAKGHOLDER } \\
\text { CATEGORIES }\end{array}$ \\
\hline $\begin{array}{l}\text { There is an advantage to sonic drilling } \\
\text { in portability, in angled drilling use } \\
\text { without drilling fluid (no secondary } \\
\text { waste), and for a wide range of } \\
\text { applications } \\
\text { - Consider using double-imploded steel } \\
\text { used in Rocky Flats barrels for the } \\
\text { drill pipe. }\end{array}$ & - $\quad$ INEL & Interest Group \\
\hline \multicolumn{3}{|l|}{ Works as Intended } \\
\hline $\begin{array}{l}\text { Evaluate the ability to achieve good- } \\
\text { quality soil samples and good, } \\
\text { representational cores. }\end{array}$ & $\begin{array}{ll}\text { - } & \text { INEL } \\
\text { - } & \text { Los Alamos } \\
& \text { Rocky Flats } \\
\text { - } & \text { Sandia }\end{array}$ & $\begin{array}{ll}- & \text { Regulator } \\
\text { - } & \text { Tribes } \\
\text { Technology User } \\
\text { Interest Group } \\
\text { - } \quad \text { Interest Group } \\
\quad \text { Intogulator }\end{array}$ \\
\hline $\begin{array}{l}\text { Evaluate the ability to drill } 500^{\prime} \text { or } \\
\text { more. }\end{array}$ & Sandia & Interest Group \\
\hline $\begin{array}{l}\text { Evaluate effects of water in the } \\
\text { saturated zone that could potentially } \\
\text { dampen vibration and slow drilling. } \\
\text { Assess the ability to drill in an aquifer. }\end{array}$ & $\begin{array}{l}\text { - } \quad \text { Los Alamos } \\
\text { INEL }\end{array}$ & $\begin{array}{ll}\text { - } & \text { Technology User } \\
\text { Regulator }\end{array}$ \\
\hline $\begin{array}{l}\text { Define whether sonic drilling and the } \\
\text { heat it generates alter the chemical or } \\
\text { physical nature of the contaminants in } \\
\text { samples or soil permeability. }\end{array}$ & $\begin{array}{l}\text { - } \quad \text { Rocky Flats } \\
\text { - } \quad \text { Sandia }\end{array}$ & $\begin{array}{ll}\text { Interest Group } \\
\text { Regulator } \\
\text { Public Official } \\
\text { Regulator } \\
\text { Technology User }\end{array}$ \\
\hline $\begin{array}{l}\text { The vibrating bit may vibrate soil } \\
\text { particles into the formation, thus } \\
\text { packing surrounding soil and skewing } \\
\text { aquifer pump test results. Consider } \\
\text { side-by-side comparison of wells } \\
\text { drilled by different methods into the } \\
\text { saturated and unsaturated zones to } \\
\text { assess comparative effects on hydraulic } \\
\text { conductivity. }\end{array}$ & $\begin{array}{ll}- & \text { INEL } \\
- & \text { Sandia } \\
- & \text { Rocky Flats }\end{array}$ & $\begin{array}{ll}\text { - } & \text { Regulator } \\
\text { - } & \text { Regulator } \\
\text { Technology User }\end{array}$ \\
\hline
\end{tabular}




\begin{tabular}{|c|c|c|c|}
\hline & ISSUES BY CATEGORY ৯ & $\begin{array}{l}\text { SITES WHERE ISSUES } \\
\text { RAISED }\end{array}$ & $\begin{array}{l}\text { STAKEHOLDER } \\
\text { CATEGORIES } \\
\end{array}$ \\
\hline - & $\begin{array}{l}\text { Define the benefits and limitations for } \\
\text { well completion and usefulness for } \\
\text { ground water monitoring, drill pipe } \\
\text { clearances, and possible range of } \\
\text { borehole diameters. }\end{array}$ & $\begin{array}{ll}- & \text { Los Alamos } \\
\text { - } & \text { Rocky Flats }\end{array}$ & $\begin{array}{l}\text { - Technology User } \\
\text { - Technology User }\end{array}$ \\
\hline • & $\begin{array}{l}\text { Demonstrate what happens when a } \\
\text { sonic drill encounters a large } \\
\text { subsurface boulder. }\end{array}$ & Rocky Flats & Regulator \\
\hline$\cdot$ & $\begin{array}{l}\text { Assess efficiency when using drilling } \\
\text { lubricants that contain no VOCs. }\end{array}$ & Rocky Flats & $\begin{array}{l}\text { Regulator } \\
\text { Technology User }\end{array}$ \\
\hline - & $\begin{array}{l}\text { Confirm that no drilling fluids are } \\
\text { needed. }\end{array}$ & Sandia & Regulator \\
\hline \multicolumn{4}{|c|}{ Cost } \\
\hline • & $\begin{array}{l}\text { Define the cost, speed, and } \\
\text { effectiveness of this technology } \\
\text { compared to other drilling } \\
\text { technologies. }\end{array}$ & $\begin{array}{ll}\text { - } & \text { Rocky Flats } \\
\text { - } & \text { Sandia }\end{array}$ & $\begin{array}{ll}- & \text { Technology User } \\
\text { Interest Group } \\
\text { Regulator } \\
\text { Technology User }\end{array}$ \\
\hline - & $\begin{array}{l}\text { Evaluate the total cost, costs per unit } \\
\text { depth, and cost effectiveness of this } \\
\text { technology }\end{array}$ & $\begin{array}{l}\text { - } \quad \text { Rocky Flats } \\
\text { - } \quad \text { Sandia }\end{array}$ & $\begin{array}{l}\text { Regulator } \\
\text { Technology User } \\
\text { Regulator } \\
\text { Technology User }\end{array}$ \\
\hline - & $\begin{array}{l}\text { Assess costs of the technology } \\
\text { considering its history in the oil and } \\
\text { gas industry and in other DOE site } \\
\text { demonstrations. }\end{array}$ & Los Alamos & Technology User \\
\hline - & $\begin{array}{l}\text { Evaluate the cost of drill strings and } \\
\text { drill pipes. }\end{array}$ & INEL & Interest Group \\
\hline - & $\begin{array}{l}\text { The lower cost of this technology is an } \\
\text { advantage; the money saved can be } \\
\text { applied to additional characterization. }\end{array}$ & Sandia & Interest Group \\
\hline
\end{tabular}




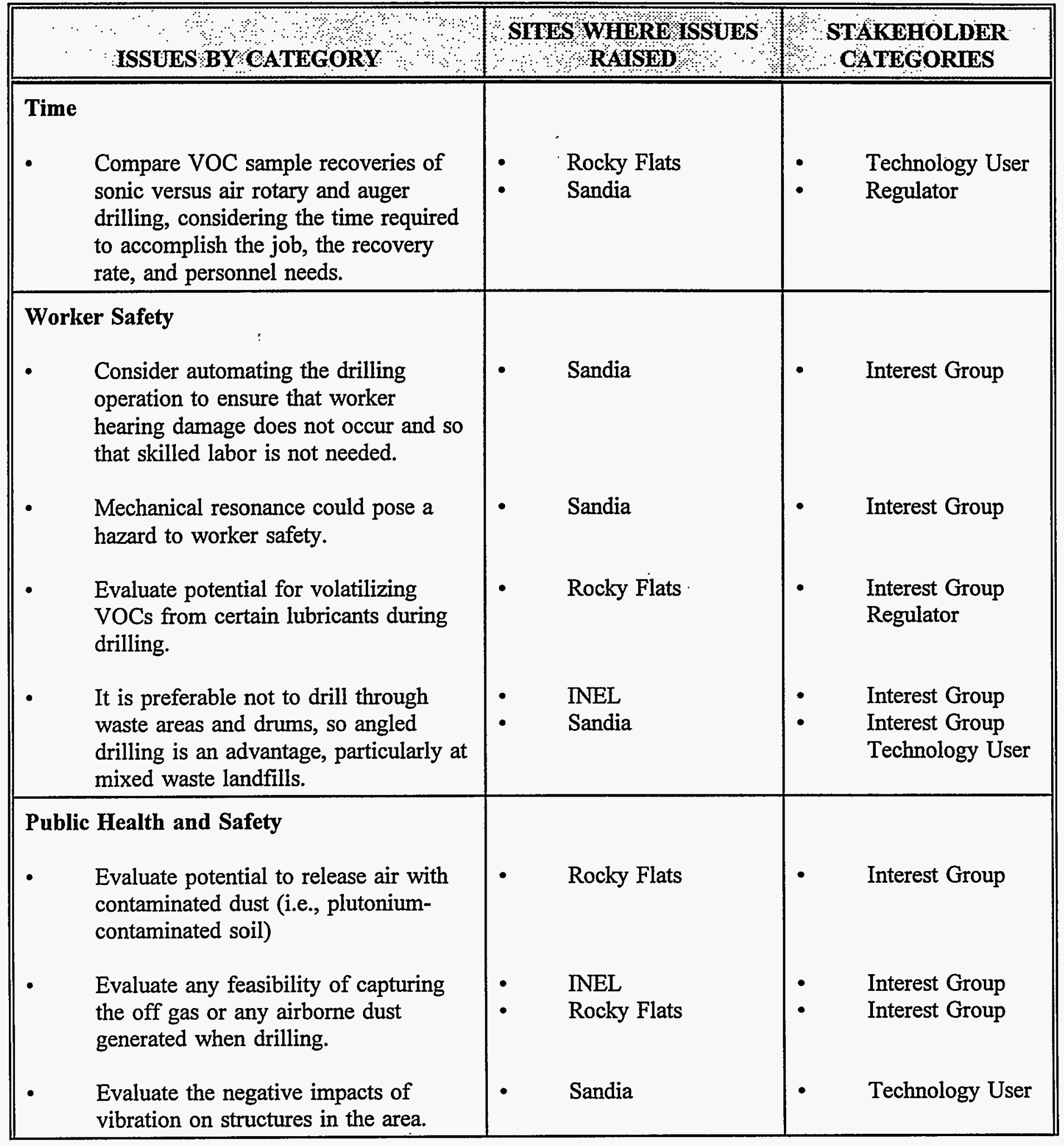




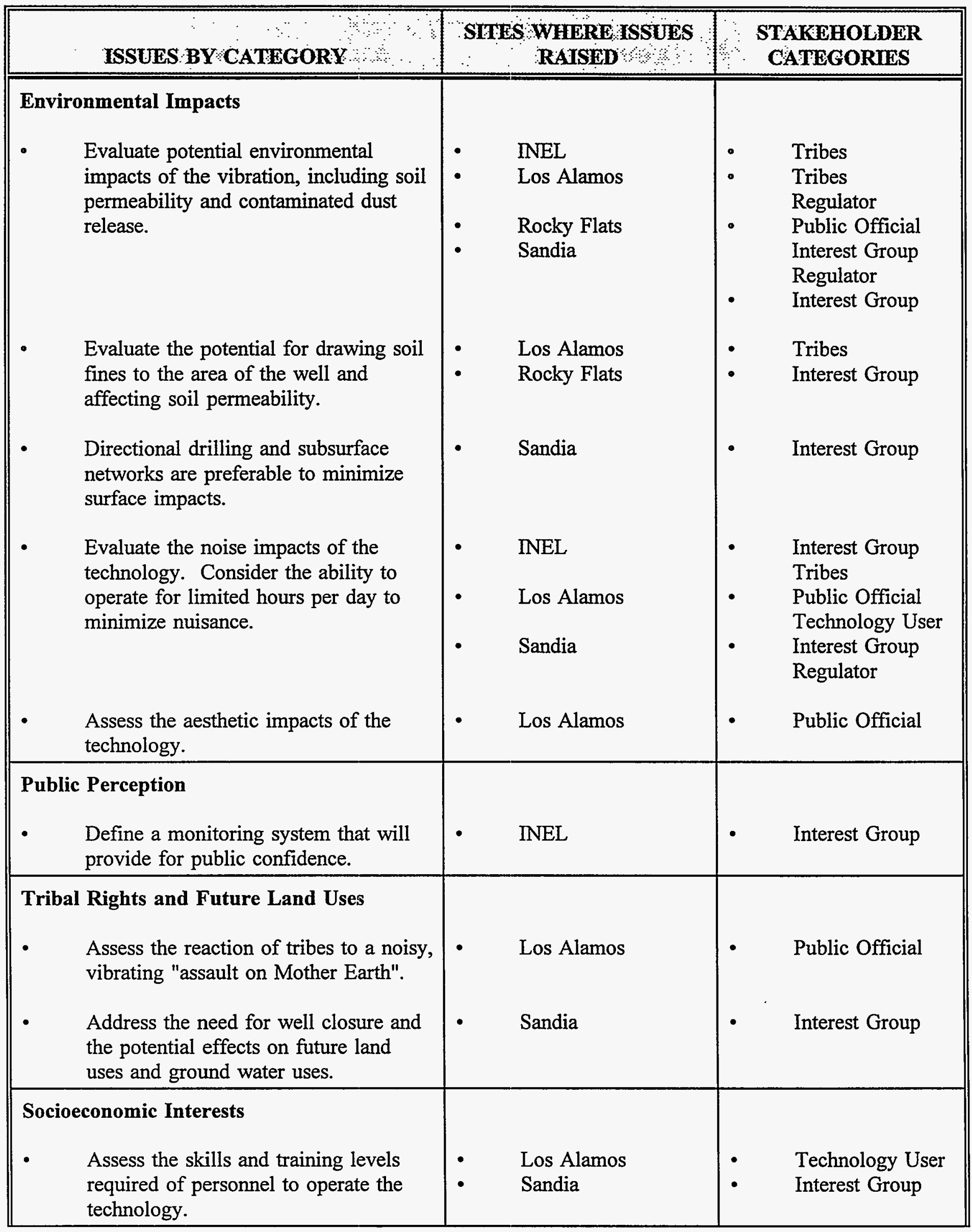




\begin{tabular}{|c|c|c|}
\hline ISSUESBYCATEGORY & SITES WHERE ISSUES & $\begin{array}{l}\text { STAKEHOLDER } \\
\text { CATEGORIES }\end{array}$ \\
\hline $\begin{array}{l}\text { Regulatory Infrastructure and Track } \\
\text { Record } \\
\text { This technology is exotic and } \\
\text { unproven. Present clear examples of } \\
\text { where this technology is better than } \\
\text { other technologies, including air rotary } \\
\text { drilling, and why. }\end{array}$ & - $\quad$ Sandia & Regulator \\
\hline $\begin{array}{l}\text { Regulatory Compliance } \\
\text { - Assess the ability of the technology to } \\
\text { comply with EPA NESHAPS } \\
\text { regulations in terms of dust production } \\
\text { and associated contaminants. }\end{array}$ & Los Alamos & Technology User \\
\hline Other & & \\
\hline $\begin{array}{l}\text { The distinct advantage of sonic drilling } \\
\text { is that it does not require drilling } \\
\text { fluids and muds. }\end{array}$ & $\begin{array}{ll}\text { - } & \text { Rocky Flats } \\
\text { - } & \text { Sandia }\end{array}$ & $\begin{array}{ll}\text { - } & \text { Interest Group } \\
& \text { Regulator } \\
\text { - } \quad \text { Technology User }\end{array}$ \\
\hline $\begin{array}{l}\text { This is an attractive, promising } \\
\text { technology. }\end{array}$ & $\begin{array}{ll}\cdot & \text { INEL } \\
\text { - } & \text { Rocky Flats } \\
\text { - } \quad \text { Sandia }\end{array}$ & $\begin{array}{ll}\text { - } & \text { Technology User } \\
\text { Interest Group } \\
\text { Public Official } \\
\text { Regulator } \\
\text { - Technology User }\end{array}$ \\
\hline $\begin{array}{l}\text { Remediation at the } 903 \text { Pad at Rocky } \\
\text { Flats needs directional drilling }\end{array}$ & Rocky Flats & Interest Group \\
\hline $\begin{array}{l}\text { Sonic drilling was approved for use at } \\
\text { Rocky Flats OU } 11 .\end{array}$ & Rocky Flats & Regulator \\
\hline
\end{tabular}




\subsection{IN-WELL VAPOR STRIPPING}

In-well vapor stripping operates below ground to remove VOCs from ground water, then raises them to the surface in vapor form for treatment. Partially cleaned water is returned to the aquifer, then recirculated through the vapor-stripping process. Ground water becomes cleaner and cleaner with each pass.

Stakeholders at all the sites provided a moderate level of input on this technology. Input from Hanford stakeholders is provided in detail in the two reports cited earlier. Principal stakeholder concerns about in-well vapor stripping fell into the categories of practicality and whether the technology will work as intended, with some significant concerns about remaining contamination, process waste, time, and environmental impacts.

Comments from Hanford stakeholders also reflected those areas of emphasis. In addition, the other arid sites provided perspectives concerning the potential broad deployment of the technology. In analyzing the comments received in each issue or criterion category, the following similarities and differences are noted.

\section{$\underline{\text { Remaining Contamination }}$}

Hanford stakeholders raised concerns about evaluating the amount and type of contamination remaining after use of in-well vapor stripping. Other sites also raised issues about the technology's ability to completely clean contaminated water, to handle other types and concentrations of VOCs, metals, and radionuclides, and to address non-aqueous phase liquids (NAPLs).

\section{Process Waste}

Hanford comments regarding process waste applied primarily to the likelihood that cocontaminants would remain in process waste. Hanford interest group representatives wanted a clear accounting of the handling of secondary waste produced by the technology.

Representatives of other sites requested specific information on off gases and secondary waste produced, including disposal needs. Concerns were expressed about "just transferring contamination from one medium to another," as well as a desire to address ultimate disposal for the process waste. A Rocky Flats regulator pointed out the problems with using GAC, and suggested considering another contaminant disposal/destruction system.

\section{Practicality}

Hanford stakeholders requested detailed information on how the technology performs in demonstration, including data on concentration and mass limits, circulation, and applicability to different geologic conditions and different contaminants. Zone of influence for the wells was a major issue, affecting time and cost requirements. The technology's effect on cocontaminants overall, especially tritium and heavy metals, was a critically important issue. 
Stakeholders discussed the need to accurately characterize aquifer conditions at Hanford, and the effect that these conditions have on in-well vapor stripping's performance. An effective monitoring system in the subsurface and at the surface should be demonstrated for this technology.

A Hanford technology user suggested that modeling be used to add data points to the one-well demonstration planned. Confidence levels of the models can be modified based on demonstration results. Clogging and loss of permeability within the aquifer were also raised as concerns. Changes in ground water level caused by use of the technology were a substantial concern, one that stakeholders thought warranted additional monitoring during demonstration. Hanford stakeholders asked for analysis of power loss during the demonstration, as well as the underground effects of air or liquid releases.

Stakeholders at other arid sites raised many of these issues and added emphasis to the question of circulation, questioning how it could be assured that new water will be drawn into the well and suggesting reinjecting cleaned water upgradient to increase effectiveness. They questioned the technology's effectiveness in heterogeneous soils and at different depths, with non-VOC contaminants, and in a pulsing mode because of slow recharge. Stakeholders advocated exploring the potential for retrofitting existing wells, and coupling this technology with other technologies.

\section{Works as Intended}

Hanford stakeholders stressed the importance of defining the parameters of successful performance in advance and using an adequate performance monitoring system. One stakeholder described "the beauty of this technology" as not having to handle large quantities of water at the surface. A question was raised about this technology causing secondary contamination, as it moves ground water from level to level in the subsurface. Stakeholders requested results of tests of this technology that have been conducted in Europe.

Specific comments from the other arid sites included a note that INEL has a deep unsaturated zone and a high-yield aquifer, requiring consideration of the technology's effectiveness in these conditions. A technology user at Los Alamos suggested using heated air to heat the water to enhance VOC transfer. The ability to operate in dense saturated zones will be an issue in New Mexico, with its fractured granite. Variations in soil permeability are also an issue at Rocky Flats. A Rocky Flats regulator wanted assurance that no water would be brought to the surface.

\section{Cost}

Hanford stakeholders requested information on capital costs as well as the cost of installation, operation, maintenance, and licensing. Cost data were requested on a removal-of-contaminant basis, in dollars per cubic yard removed. The baseline for comparison should be pump and 
treat. Breakpoint modeling should be done to see where pump and treat becomes equal in cost to in-well vapor stripping.

Stakeholders at the other arid sites requested basically the same cost information, but added costs for the numbers of wells needed to address a given situation, and consideration of how long water must be cycled through the unit.

\section{Worker Safety}

No particular comments were received on worker safety, though one Los Alamos technology user raised the possibility of explosion.

\section{Public Health and Safety}

Effects of contaminants released from sampling ports or other above-ground locations should be determined, as well as pressurized vapor releases into the subsurface due to failure, according to Hanford stakeholders. Engineered controls to avoid health and safety threats were suggested, as well as public information on the potential for releasing vaporized carbon tetrachloride. Monitoring for off-gas releases during operation is essential. At other arid sites, stakeholders shared these concerns, stressing the importance of capturing and monitoring off-gas releases.

\section{Environmental Impacts}

Hanford stakeholders, particularly regulators, see significant environmental risk associated with subsurface spread of contamination. They urged that the test plan thoroughly address subsurface monitoring and control. They also requested demonstration data on the effects of ground water rising into the vadose zone, and subsurface effects of recirculation on the aquifer and vadose zone. A tribal representative at INEL expressed the advantage of treating the water without removing it from the aquifer, but concern was also expressed about moving contaminants beyond the treatment zone and causing mounding and changes in water chemistry.

\section{$\underline{\text { Public Perception }}$}

Hanford stakeholders made no comment on public perception of in-well vapor stripping. New Mexico and some Colorado stakeholders indicated that it is a variation of a demonstrated technology, and should be acceptable; its "low-tech" image will make it attractive and familiar to regulators and the public. 


\section{$\underline{\text { Socio-Economic Interests }}$}

Hanford stakeholders made no comment on socio-economic interests relative to in-well vapor stripping. A Sandia technology user recommended evaluating the availability of a work force able to operate the technology.

\section{Regulatory Infrastructure and Track Record}

Hanford stakeholders cautioned that all applicable regulations and regulatory precedents for this or similar technologies be identified. There is no specific regulatory framework for this class of technologies, which move ground water within the subsurface, and no regulatory or operating track record. It is important to work with regulators to establish mechanisms for permitting and to deal directly with regulatory concerns. Specifically, there is a need to address whether changing the ground water level would create regulatory concern. Several stakeholders from the other arid sites had conflicting viewpoints regarding regulator familiarity with the technology.

\section{$\underline{\text { Regulatory Compliance }}$}

Hanford stakeholders mentioned only that compliance with drinking water and other water standards must be assured after use of in-well stripping. Clean Air Act permits may be required for air discharges, especially in New Mexico, but no ground water discharge permit should be required as no treated water must be disposed.

Table 2 on the following pages summarizes the comments of stakeholders at the other arid sites on in-well vapor stripping, organized by criterion category. 
Table 2 - IN-WELL VAPOR STRIPPING COMMENT LISTING

\begin{tabular}{|c|c|c|}
\hline ISSUESBY CATEGORY & $\begin{array}{l}\text { STIES WHERH ISSUES } \\
\text { RAISED }\end{array}$ & $\begin{array}{l}\text { STAKEHOLDER } \\
\text { CATEGORIES }\end{array}$ \\
\hline \multicolumn{3}{|l|}{ Remaining Contamination } \\
\hline $\begin{array}{l}\text { Assess how completely the technology } \\
\text { captures contaminants and its } \\
\text { effectiveness in capturing different } \\
\text { concentrations of carbon tetrachloride. } \\
\text { Are all volatiles stripped, or just those } \\
\text { with lower or higher molecular } \\
\text { weight? }\end{array}$ & $\begin{array}{ll}\cdot & \text { INEL } \\
\text { - } & \text { Rocky Flats }\end{array}$ & $\begin{array}{ll}\text { - } & \text { Interest Group } \\
\text { - } & \text { Regulator }\end{array}$ \\
\hline $\begin{array}{l}\text { Consider the effects of co- } \\
\text { contaminants, the potential side effects, } \\
\text { and the levels of removal achieved. } \\
\text { Assess the cost effectiveness of having } \\
\text { separate systems for co-contaminants. }\end{array}$ & $\begin{array}{ll}\text { - } & \text { INEL } \\
\text { - } & \text { Rocky Flats } \\
\text { Sandia }\end{array}$ & $\begin{array}{ll}\text { - } & \text { Interest Group } \\
\text { - } & \text { Regulator } \\
& \text { Interest Group }\end{array}$ \\
\hline $\begin{array}{l}\text { Demonstrate the technology's ability to } \\
\text { reduce contamination faster than pump } \\
\text { and treat. }\end{array}$ & INEL & Technology User \\
\hline $\begin{array}{l}\text { There is concern about spreading } \\
\text { contamination in ground water, and } \\
\text { vadose-to-ground water contaminant } \\
\text { transfer through returning stripped } \\
\text { ground water. }\end{array}$ & $\begin{array}{ll}\text { - } & \text { INEL } \\
\text { - } & \text { Sandia }\end{array}$ & $\begin{array}{ll}- & \text { Interest Group } \\
- & \text { Interest Group }\end{array}$ \\
\hline $\begin{array}{l}\text { Consider the use of liquid nitrogen, } \\
\text { with its expansion coefficient, to } \\
\text { enable greater removal of VOCs. }\end{array}$ & Los Alamos & Technology User \\
\hline $\begin{array}{l}\text { Assess the effectiveness of the } \\
\text { technology for NAPLs; will it disperse } \\
\text { the non-aqueous phase liquids } \\
\text { (NAPLs)? }\end{array}$ & Rocky Flats & Regulator \\
\hline
\end{tabular}




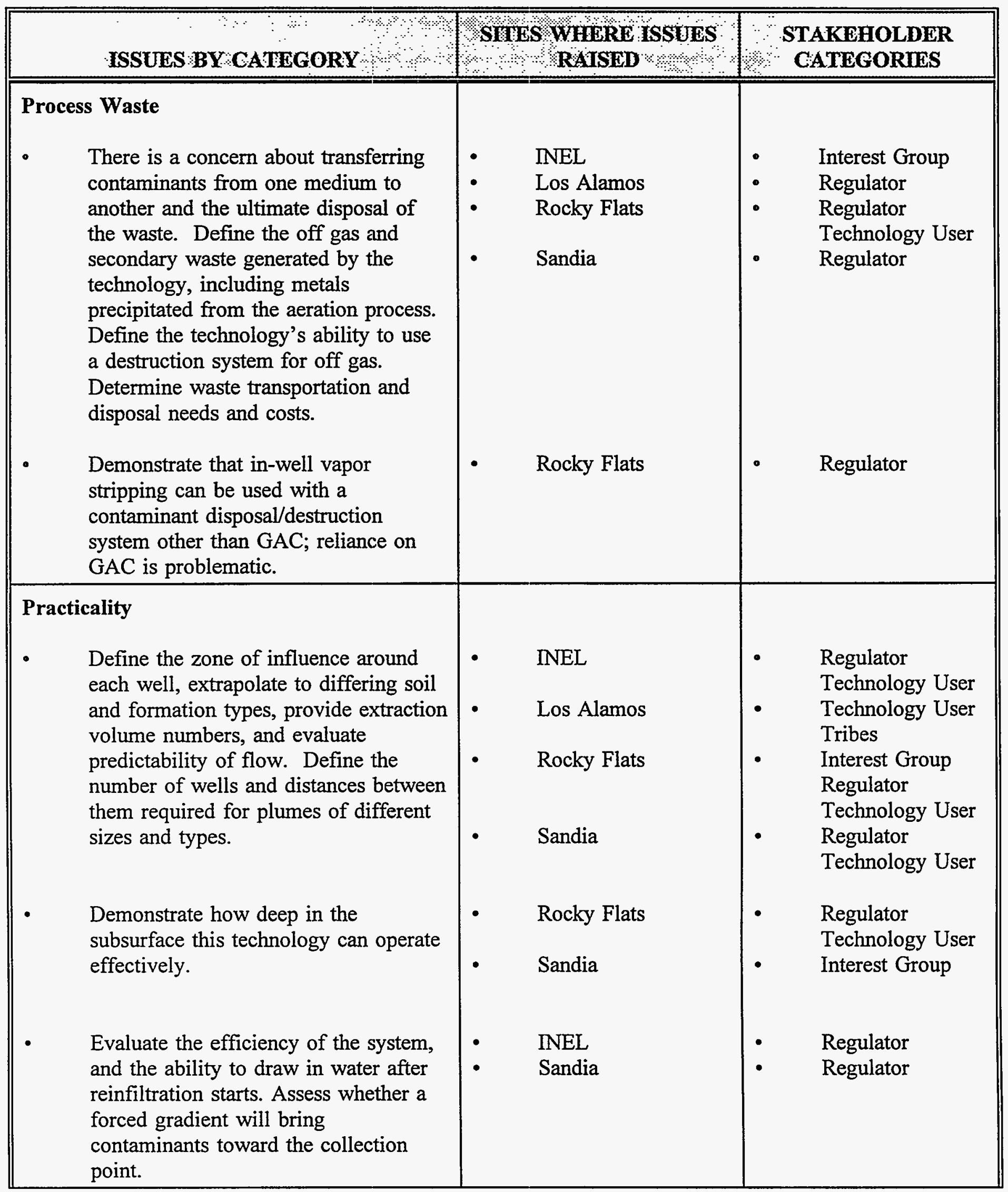


- Confirm the ability to use the technology broadly. This technology's transferability is an advantage.

Evaluate differing efficiencies with changes of the well screen and packer relative to the water table; evaluate the cost for modifying the well screen elevations to maintain expected efficiencies.

Evaluate the ability of the technology to be coupled with bioremediation.

Assess performance with different types of off-gas treatment systems.

Evaluate the ability of the technology to retrofit existing water supply and monitoring wells. Define well size ranges and relate to the radii of influence.

Evaluate alternative sources for procuring the technology; there appears to be single source.

Consider using the technology with surfactants for DNAPLs and sorbed VOCs.

Evaluate the pumping rate needed to get appropriate withdrawal without overpumping; expect capture problems.

Assess the need to circulate new water into the well to keep from treating the same water over and over.

- An advantage to this technology is that it addresses all VOCs.

Evaluate enhanced degradation at the well due to air circulation.

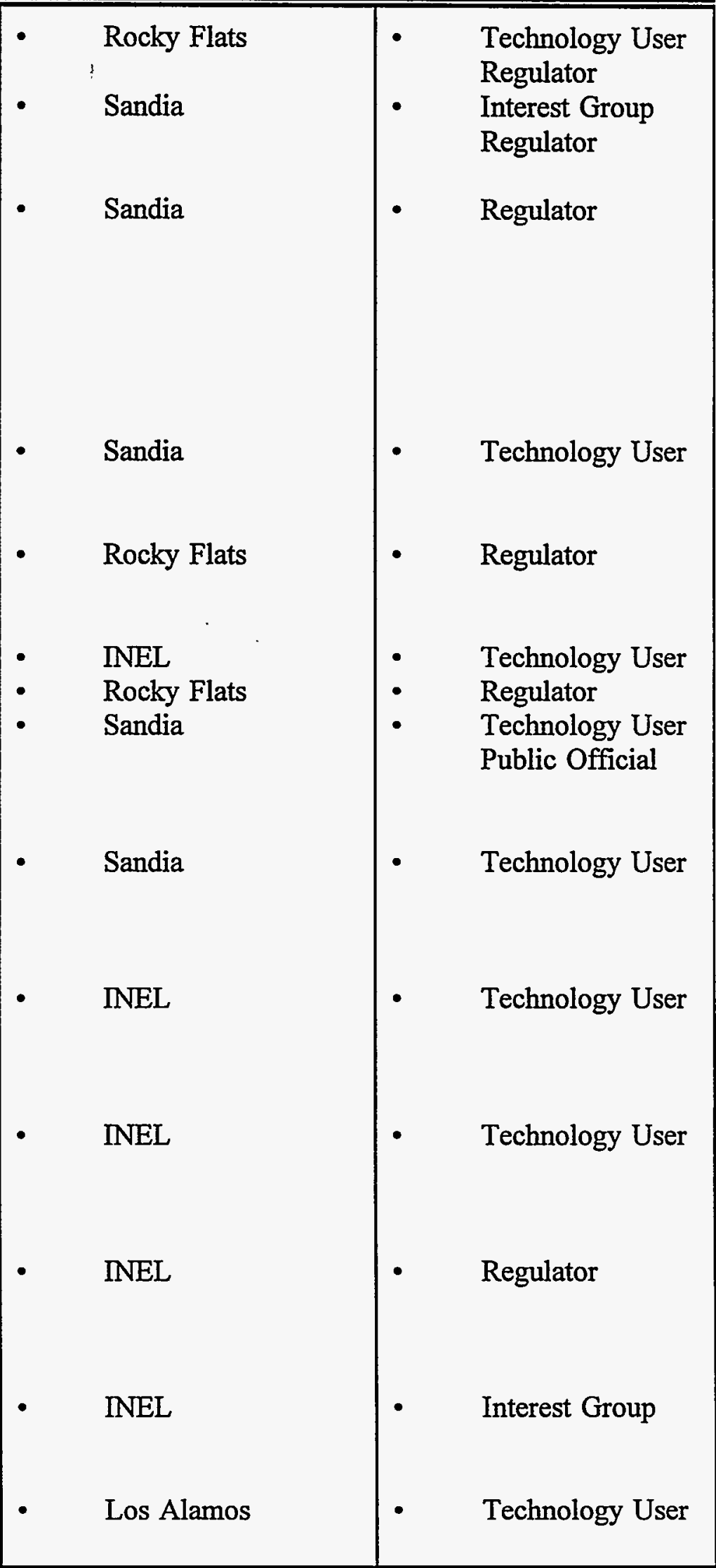




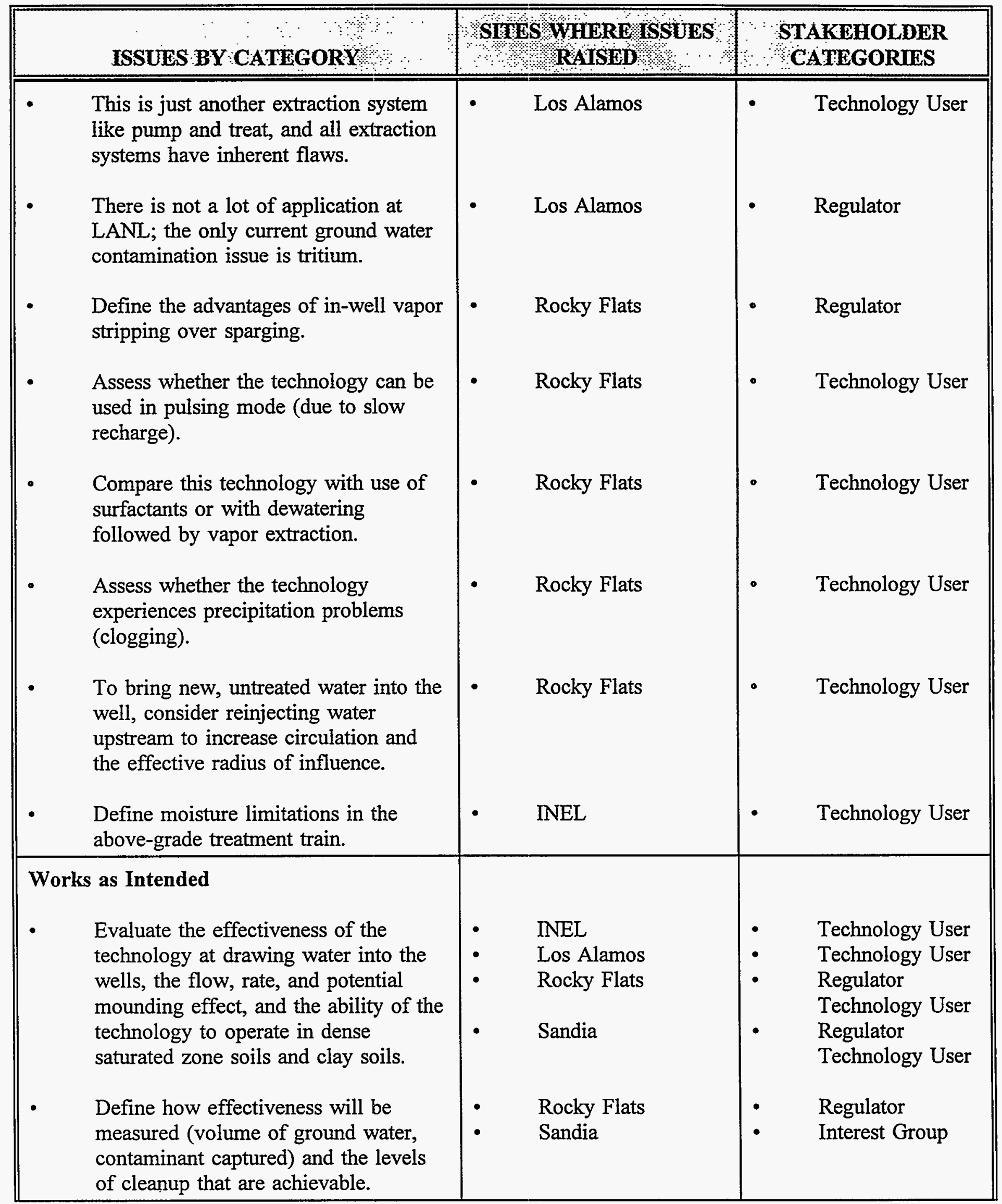




\begin{tabular}{|c|c|c|c|}
\hline$\therefore$ & ISSUES BY CATEGORY & SIYES WHERE ISSUES & $\begin{array}{l}\text { STAKEHOLDER } \\
\text { CATEGORIES }\end{array}$ \\
\hline - & $\begin{array}{l}\text { Quantify the recirculation } \\
\text { characteristics of the technology, the } \\
\text { ability to set up circulating cells, the } \\
\text { size of the circulation pattern, and the } \\
\text { possibility of spreading the plume. } \\
\text { Demonstrate how many times } \\
\text { contaminated water has to be } \\
\text { recirculated through the technology, } \\
\text { and at what cost, to reach each cleanup } \\
\text { level. }\end{array}$ & $\begin{array}{ll}- & \text { Los Alamos } \\
\text { - } & \text { Rocky Flats } \\
& \text { Sandia }\end{array}$ & $\begin{array}{ll}\text { - } & \text { Technology User } \\
\text { Regulator } \\
\text { Technology User } \\
\text { - } \\
\text { Regulator }\end{array}$ \\
\hline - & $\begin{array}{l}\text { Consider other influences, such as } \\
\text { water supply wells, on the } \\
\text { technology's operation. }\end{array}$ & - $\quad$ Sandia & Regulator \\
\hline - & $\begin{array}{l}\text { Consider heating water to enhance } \\
\text { VOC transfer. }\end{array}$ & - Los Alamos & Technology User \\
\hline • & $\begin{array}{l}\text { Consider returning cleaned water } \\
\text { upgradient of the well, outside the } \\
\text { zone of influence, to push } \\
\text { contamination toward the stripping } \\
\text { well. }\end{array}$ & Sandia & Technology User \\
\hline • & $\begin{array}{l}\text { Define the function and effectiveness } \\
\text { of the packer (separator plate). There } \\
\text { is concern about packers not staying in } \\
\text { place, and creating maintenance } \\
\text { problems. }\end{array}$ & $\begin{array}{l}\text { - } \quad \text { INEL } \\
\quad \text { Los Alamos }\end{array}$ & $\begin{array}{ll}- & \text { Regulator } \\
\text { - } & \text { Technology User }\end{array}$ \\
\hline • & $\begin{array}{l}\text { Demonstrate what prevents volatiles } \\
\text { from bypassing the extraction wells. }\end{array}$ & - $\quad$ Rocky Flats & Regulator \\
\hline • & $\begin{array}{l}\text { Determine in-well vapor stripping's } \\
\text { applicability by determining how long } \\
\text { it will take for contamination at a } \\
\text { particular site to migrate. }\end{array}$ & Rocky Flats & Interest Group \\
\hline Cost & $\begin{array}{l}\text { Assess the numbers of wells needed to } \\
\text { implement the technology. }\end{array}$ & Sandia & Regulator \\
\hline
\end{tabular}




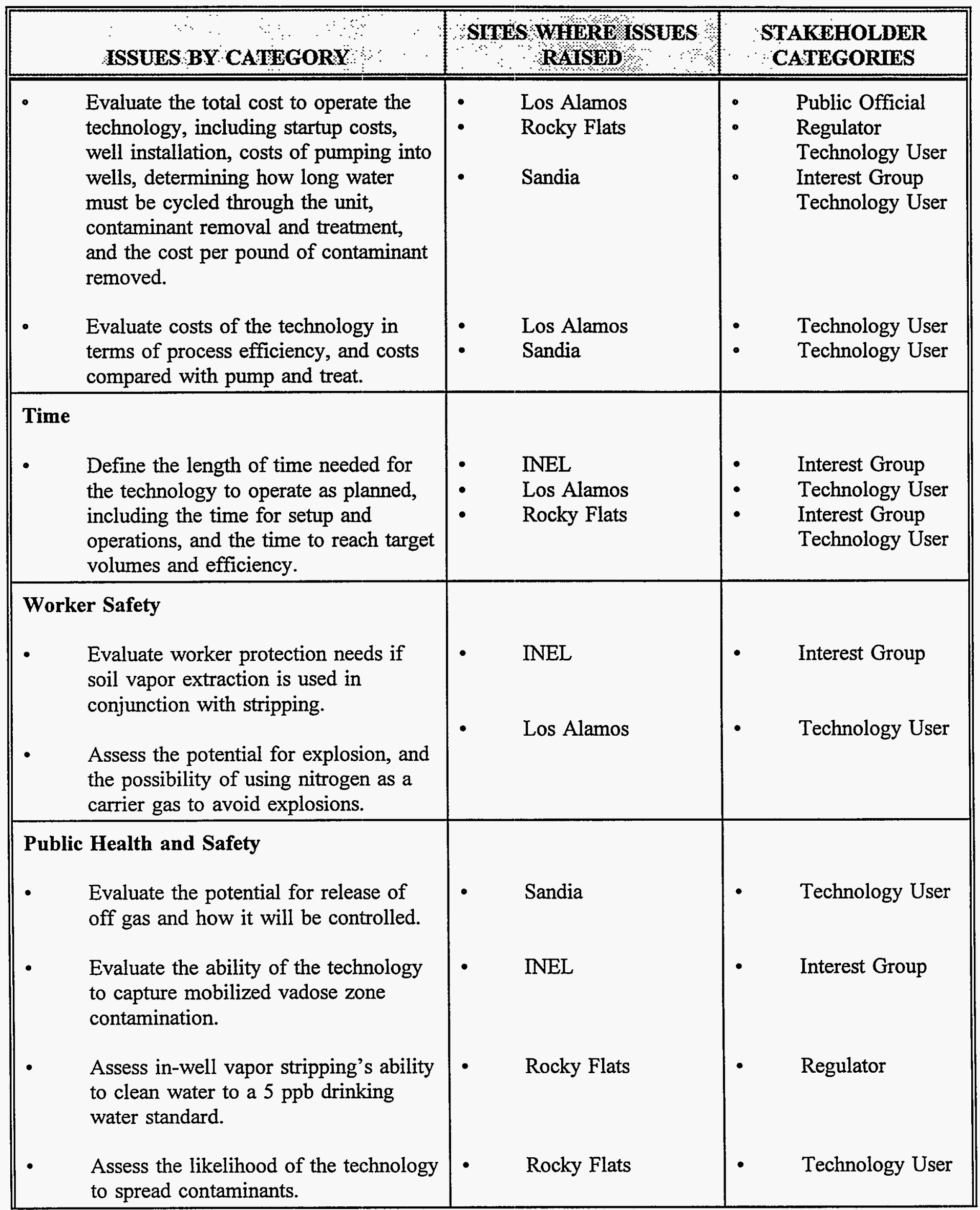




\begin{tabular}{|c|c|c|}
\hline ISSUES BY CATEGORY & SHIES WHERE ISSUES & $\begin{array}{l}\text { STAKEHOLDER } \\
\text { CATEGORIES }\end{array}$ \\
\hline $\begin{array}{l}\text { Environmental Impacts } \\
\text { Assess mounding, water chemistry } \\
\text { changes, and mixing characteristics in } \\
\text { the aquifer resulting from use of the } \\
\text { technology. }\end{array}$ & Sandia & Regulator \\
\hline $\begin{array}{l}\text { Evaluate whether packer materials will } \\
\text { affect water quality. }\end{array}$ & Sandia & Interest Group \\
\hline $\begin{array}{l}\text { Determine whether some contaminants } \\
\text { are moved beyond the treatment zone. }\end{array}$ & INEL & \\
\hline $\begin{array}{l}\text { Assess whether the technology } \\
\text { increases biomass in the aquifer. }\end{array}$ & Rocky Flats & Technology User \\
\hline $\begin{array}{l}\text { This technology offers the advantages } \\
\text { of bringing only gas to the surface and } \\
\text { leaving contaminated ground water } \\
\text { below; of eliminating the need to } \\
\text { reinject ground water; and of not } \\
\text { pumping, particularly when } \\
\text { contaminated water is deep. }\end{array}$ & $\begin{array}{ll}\text { - } & \text { INEL } \\
\text { - } & \text { Los Alamos } \\
\text { - } & \text { Sandia }\end{array}$ & $\begin{array}{ll}\text { - } & \text { Technology User } \\
\text { - } & \text { Iribes } \\
\text { - } & \text { Interest Group } \\
& \text { Interest Group }\end{array}$ \\
\hline $\begin{array}{l}\text { Public Perception } \\
\text { Because the in-well vapor stripping } \\
\text { system is a modification of air } \\
\text { sparging technology already in use, } \\
\text { this technology should be acceptable } \\
\text { for projects funded with public money. }\end{array}$ & Sandia & Technology User \\
\hline $\begin{array}{l}\text { The "low-tech" nature of this } \\
\text { technology makes it attractive, and it } \\
\text { is familiar to regulators and the public. }\end{array}$ & Los Alamos & Regulator \\
\hline $\begin{array}{l}\text { Socio-Economic Interests } \\
\text { Evaluate the availability of a work } \\
\text { force competent to operate the } \\
\text { technology. }\end{array}$ & Sandia & Technology User \\
\hline
\end{tabular}




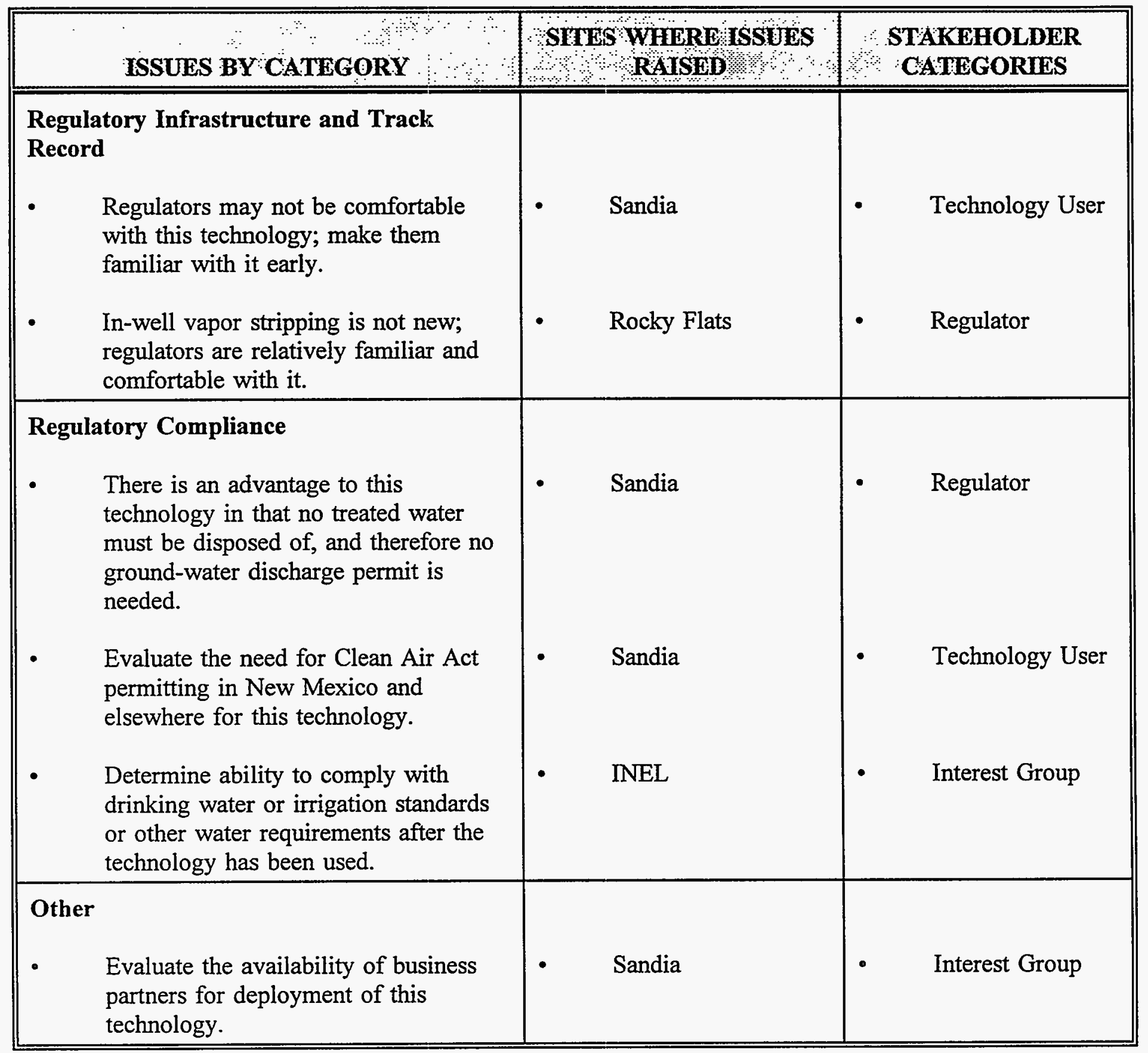




\subsection{MEMBRANE SEPARATION}

Membrane separation treatment of VOC-laden gas, streams at the surface raised a moderate number of questions and information requests with stakeholders at all of the sites. Input from Hanford stakeholders is provided in detail in the two reports cited earlier. Principal stakeholder concerns about membrane separation related to process waste, practicality, and cost. Whether the technology works as intended and environmental impacts were raised more often specifically at Sandia. This technology was evaluated for use at Rocky Flats, but concerns were raised about reliability, implementability, lack of a track record, and rapid availability in the field; it was not selected for use.

Hanford stakeholders emphasized questions of process waste, practicality, and cost. Their comments were similar in level of detail to those of the other sites. In analyzing the comments received in each issue or criterion category, the following similarities and differences are noted.

\section{Remaining Contamination}

Only a few comments were received in this category. The ability to address co-contaminants, and to reach regulatory limits (5 ppb, in ground water in New Mexico with low levels of contaminant and high volumes of water, for example) were raised as design considerations for deployment. The ability to address radionuclides or particulates was also questioned.

\section{Process Waste}

Hanford stakeholders focused on the issue of process waste from membrane separation and the use of GAC. Recycling the condensed contaminant is desirable, and the ID should indicate whether process waste volumes and costs are reduced through use of this technology.

Stakeholders indicated that the risks related to transporting GAC and the reduced availability of land disposal made the use of membrane separation a more attractive technology than GAC alone. Stakeholders raised concerns about the possibility of tritium being contained in the condensed liquid or in the GAC. Similarly, stakeholders expressed concern about whether radon will be contained in the resulting liquid or waste, and about regulatory and DOE limitations for radon.

Stakeholders at the other arid sites were quite concerned about the waste produced by the membrane separation process. The creation of liquid secondary waste, with requirements for storage, treatment, and shipping off site, was seen as a significant disadvantage at all-the other arid sites. A Rocky Flats regulator cited the disadvantage of contributing to three separate waste streams: GAC, the membrane itself, and the condensed liquid contaminant, especially in consideration of the severe shortage of waste storage capacity at Rocky Flats. Stakeholders doubted that there is a market for the reclaimed carbon tetrachloride, noting its listing as a hazardous waste, and doubted its ability to compete with pure, virgin solvent. Complete destruction was seen as preferable, with no need to store or transport off site. A Rocky Flats 
technology user, however, indicated that liquid waste is preferable to off gas requiring treatment, as off-gas treatment systems are hard to site and maintain, and are complex and expensive.

\section{Practicality}

Hanford stakeholder comments about the practicality of membrane separation focused on its versatility and reliability. Stakeholders raised questions about its applicability to other VOCs and whether tritium or other co-contaminants (e.g., plutonium, other VOCs, semi-volatiles) affect the process. They wanted to be shown whether the technology is better suited to the vadose zone or saturated zone, and whether it is effective with high concentrations of contaminants. The length of time the membrane will last was a major concern for Hanford technology users. They said it is important to identify the range of contaminated areas for which the technology is economical and effective. Ease and simplicity of operating the technology should also be evaluated.

At the other arid sites, comments focused in the same areas, but identified more detailed data requirements. The technology's operating limits should be well understood, including ability to operate in extreme temperatures, with minimal personnel involvement, at a full range of concentrations (less than $300 \mathrm{ppm}$ at INEL and Rocky Flats), on mixed organics, and with solar or propane power for remote locations. The potential for membrane fouling and regeneration was raised at all sites, and operating variations (e.g., pulsed operation, a lengthier, lower-temperature condensation step) were suggested.

\section{Works as Intended}

Hanford stakeholders provided no specific comments in this category. Other stakeholders suggested evaluating membrane separation against existing technologies in terms of its function.

\section{$\underline{\text { Cost }}$}

Hanford stakeholders requested demonstration data on total cost per pound for contaminant removal, including subsequent treatment of liquid waste and GAC. Stakeholders suggested measuring the decrease in GAC used based on pounds of VOC removed, allowing a true measure of dollars per pound of VOC removed. Useful life of membranes is an important factor, especially as it relates to cost comparisons. Other sites expressed skepticism about low projected costs, and requested realistic and detailed cost analyses with defined assumptions. They urged cost comparisons with other commercially available treatment methods (e.g., PURUS and catalytic oxidization).

Time

The issue of time was not of significant concern at Hanford or elsewhere. 


\section{Worker Safety}

No comments were received from Hanford stakeholders specific to this issue. At INEL, there was interest in the level of worker-protective equipment needed. At the New Mexico sites, characteristically high background radon concentrations may create radon buildup during operations; this will need to be evaluated.

\section{Public Health and Safety}

No Hanford comments were received regarding public health and safety of membrane separation. An INEL interest group representative questioned off-gas releases and their potential effects on public health and safety.

\section{Environmental Impacts}

Hanford stakeholders raised no significant issues related to environmental impacts of this technology. Stakeholders at other sites requested information on power needs, noise, and aesthetic impacts. As with other technologies, New Mexico stakeholders raised air quality permitting requirements as an issue. If new, purer power is needed to operate the membrane separation unit, such generation sources would need Clean Air Act permits, which are hard to obtain in New Mexico.

\section{$\underline{\text { Public Perception }}$}

Hanford stakeholders indicated that since this is an above-ground technology, it is easier to understand, monitor, and evaluate, than if it operated in the subsurface. Liquid waste was seen as preferable to saturated GAC. A Los Alamos interest group affirmed the advantages of above-ground operation, but cautioned against the subsequent risk of spills or releases. The simplicity of the technology was seen as an advantage to public understanding.

\section{Tribal Rights and Future Land Uses}

No specific comments about membrane separation were received in this category.

\section{$\underline{\text { Socio-Economic Interests }}$}

Some Rocky Flats stakeholders questioned whether carbon tetrachloride by-products would have commercial value and provide a basis for business.

\section{Compatibility with Cleanup Milestones}

Technology users at Rocky Flats indicated that one reason membrane separation was not selected for use there was that cleanup milestones were approaching quickly, and there was not time to resolve outstanding questions about the technology. 


\section{Regulatory Infrastructure and Track Record}

Hanford regulators indicated that there is a regulatory infrastructure in place to address membrane separation, although existing regulatory decision documents may specify use of GAC. Analysis of regulatory requirements should include management of the process waste the technology produces. One Sandia technology user stressed the importance of evaluating the regulators' familiarity with the technology in order to allow its selection as a remedy.

\section{$\underline{\text { Regulatory Compliance }}$}

The condensed liquid produced by membrane separation was seen by Hanford stakeholders as a regulatory concern. This was echoed at INEL, where liquid waste VOCs are considered a RCRA listed hazardous waste. In New Mexico, as with other technologies, the need to meet state air standards for stack gas is seen as a major regulatory compliance issue. A Rocky Flats regulator noted that the CERCLA preference for permanent remedies might work against membrane separation, which is essentially a media transfer technology.

Table 3 on the following pages summarizes comments of stakeholders at the other arid sites on membrane separation, organized by criterion category. 


\begin{tabular}{|c|c|c|c|}
\hline & ISSUES BY CATEGORY & $\begin{array}{l}\text { SIIES WHERE ISSUES } \\
\text { RAISED }\end{array}$ & $\begin{array}{l}\text { STAKEHOLDER } \\
\text { CATEGORIES }\end{array}$ \\
\hline \multicolumn{4}{|c|}{ Remaining Contamination } \\
\hline & $\begin{array}{l}\text { Evaluate the technology's ability to } \\
\text { remediate down to } 5 \mathrm{ppb} \text { in ground } \\
\text { water with low (15 ppb) levels of } \\
\text { contamination and high volumes of } \\
\text { water. }\end{array}$ & Sandia & Regulator \\
\hline & $\begin{array}{l}\text { Assess the technology's ability to } \\
\text { address TCE and PCE, which are } \\
\text { found at INEL. }\end{array}$ & INEL & Interest Group \\
\hline - & $\begin{array}{l}\text { Define the technology's ability to } \\
\text { remove radionuclides or particulates } \\
\text { before passing vapor through the } \\
\text { membrane, and the needs for } \\
\text { management of those materials. }\end{array}$ & Rocky Flats & Technology User \\
\hline \multicolumn{4}{|c|}{ Process Waste } \\
\hline & $\begin{array}{l}\text { Evaluate the quantity and } \\
\text { characteristics of secondary waste } \\
\text { produced, including requirements for } \\
\text { storage, treatment, off-site } \\
\text { transportation, disposal, and waste } \\
\text { minimization. }\end{array}$ & $\begin{array}{ll}\text { - } & \text { INEL } \\
\text { - } & \text { Los Alamos } \\
\text { - Sandia }\end{array}$ & $\begin{array}{ll}\text { Interest Group } \\
\text { Technology User } \\
\text { Tribes } \\
\text { - } \quad \text { Public Official } \\
\text { Interest Group } \\
\text { Technology User }\end{array}$ \\
\hline - & $\begin{array}{l}\text { The disposal of GAC associated with } \\
\text { this or other technologies is a problem } \\
\text { for INEL. }\end{array}$ & - $\quad$ INEL & Technology User \\
\hline - & $\begin{array}{l}\text { Evaluate other technologies that } \\
\text { compete but don't generate secondary } \\
\text { waste (membrane, GAC, liquid waste). } \\
\text { Complete destruction and one-step } \\
\text { technologies are preferable. }\end{array}$ & $\begin{array}{ll}\text { - } & \text { INEL } \\
\text { - } & \text { Rocky Flats } \\
\text { Sandia }\end{array}$ & $\begin{array}{ll}\text { - } & \text { Technology User } \\
\text { - } & \text { Regulator } \\
\text { Interest Group } \\
\text { Technology User }\end{array}$ \\
\hline - & $\begin{array}{l}\text { Regenerating GAC onsite is preferable } \\
\text { to transporting it. }\end{array}$ & Sandia & Interest Group \\
\hline - & $\begin{array}{l}\text { Compare the economics of recycling } \\
\text { secondary waste versus destruction on } \\
\text { site. }\end{array}$ & - $\quad$ INEL & Interest Group \\
\hline
\end{tabular}




\begin{tabular}{|c|c|c|}
\hline ISSUES BY CATEGORY & $\begin{array}{l}\text { SITES WHERE ISSUES } \\
\text { RAISED }\end{array}$ & $\begin{array}{l}\text { STAKEHOLDER } \\
\text { CATEGORIES }\end{array}$ \\
\hline $\begin{array}{l}\text { Determine the processing steps and } \\
\text { costs necessary to get carbon } \\
\text { tetrachloride pure enough to be } \\
\text { sold/recycled. Determine how pure } \\
\text { the technology's carbon tetrachloride } \\
\text { condensate is, and whether it can be } \\
\text { sold competively with solvents from } \\
\text { other sources. Define any needed } \\
\text { further processing, and the costs of } \\
\text { that processing. }\end{array}$ & $\begin{array}{l}\text { - } \quad \text { NEL } \\
\text { - } \quad \text { Rocky Flats }\end{array}$ & $\begin{array}{l}\text { Interest Group } \\
\text { Technology User } \\
\text { Regulator }\end{array}$ \\
\hline $\begin{array}{l}\text { Investigate the ability to reuse/recycle } \\
\text { TCE after condensation. }\end{array}$ & - $\quad$ Sandia & Technology User \\
\hline $\begin{array}{l}\text { Consider combining membrane } \\
\text { separation with tunable hybrid plasma } \\
\text { so there is less residual contamination } \\
\text { in the resulting stack gas. }\end{array}$ & • $\quad$ INEL & Interest Group \\
\hline $\begin{array}{l}\text { Off-gas treatment systems are hard to } \\
\text { maintain, expensive, and complex; the } \\
\text { benefit of membrane separation is that } \\
\text { it produces a liquid waste rather than } \\
\text { off gas requiring treatment. }\end{array}$ & Rocky Flats & Technology User \\
\hline \multicolumn{3}{|l|}{ Practicality } \\
\hline $\begin{array}{l}\text { Assess membrane reliability and } \\
\text { specifications (standard or custom), } \\
\text { including monitoring needs, evaluation } \\
\text { of membrane fouling and required } \\
\text { response to membrane fouling (the } \\
\text { ability to clean, flush, reuse, or } \\
\text { regenerate the membrane), the } \\
\text { maximum flow and range of flow } \\
\text { achievable with membranes, and the } \\
\text { potential for leakage and failure and } \\
\text { the management of the resulting liquid. }\end{array}$ & $\begin{array}{l}\text { - } \quad \text { INEL } \\
\text { - } \quad \text { Rocky Flats } \\
\text { - } \quad \text { Sandia }\end{array}$ & $\begin{array}{l}\text { Interest Group } \\
\text { Technology User } \\
\text { Regulator } \\
\text { Technology User } \\
\text { Interest Group } \\
\text { Regulator } \\
\text { Technology User }\end{array}$ \\
\hline
\end{tabular}




\begin{tabular}{|c|c|c|c|}
\hline & ISSUES BY CATEGORY & $\begin{array}{l}\text { SHTES WHERE ISSUES } \\
\text { RAISED }\end{array}$ & $\begin{array}{l}\text { STAKEHOLDER } \\
\text { CCATEGORIES }\end{array}$ \\
\hline - & $\begin{array}{l}\text { Assess the range of the technology's } \\
\text { application, including the method and } \\
\text { efficiency of vapor recovery, the } \\
\text { ability to capture all VOCs and to } \\
\text { handle multiple waste streams, the } \\
\text { ability to deal with TCE and mixed } \\
\text { organics, the ability to handle pulsed } \\
\text { flows, the ability to treat air stripping } \\
\text { tower off gas, the ability to work in } \\
\text { conjunction with PSVE, system sizing } \\
\text { for different uses, and effectiveness for } \\
\text { the final stages of site remediation. }\end{array}$ & $\begin{array}{ll}- & \text { INEL } \\
\text { - } & \text { Los Alamos } \\
& \text { Rocky Flats } \\
\text { - } & \text { Sandia }\end{array}$ & $\begin{array}{ll}- & \text { Technology User } \\
- & \text { Technology User } \\
\text { - } & \text { Interest Group } \\
\text { Regulator } \\
\text { Technology User } \\
\text { - } \quad \text { Regulator } \\
\text { Technology User }\end{array}$ \\
\hline - & $\begin{array}{l}\text { Define cleanup rates and ranges of } \\
\text { concentrations at which membrane } \\
\text { separation is effective. Assess the } \\
\text { ability to handle low concentrations. }\end{array}$ & $\begin{array}{ll}- & \text { INEL } \\
\text { - } & \text { Rocky Flats } \\
\text { - } & \text { Sandia }\end{array}$ & $\begin{array}{ll}\text { - } & \text { Technology User } \\
\text { Regulator } \\
\text { Technology User } \\
\text { - } \quad \text { Regulator }\end{array}$ \\
\hline - & $\begin{array}{l}\text { Evaluate the availability from multiple } \\
\text { vendors; there appears to be a single } \\
\text { source. }\end{array}$ & Sandia & Technology User \\
\hline - & $\begin{array}{l}\text { Evaluate security arrangements that } \\
\text { will be needed; this technology may be } \\
\text { subject to being vandalized. }\end{array}$ & Sandia & Technology User \\
\hline - & $\begin{array}{l}\text { The technology is not practical for a } \\
\text { majority of circumstances; it is too } \\
\text { sophisticated for most uses. }\end{array}$ & Sandia & Technology User \\
\hline • & $\begin{array}{l}\text { Evaluate power needs, sources, and } \\
\text { costs. The technology power source } \\
\text { would need to be solar or propane at } \\
\text { remote INEL locations. }\end{array}$ & INEL & $\begin{array}{l}\text { Interest Group } \\
\text { Technology User }\end{array}$ \\
\hline • & $\begin{array}{l}\text { This technology duplicates the function } \\
\text { of PURUS, which is available off-the- } \\
\text { shelf and adaptable. }\end{array}$ & INEL & Technology User \\
\hline - & $\begin{array}{l}\text { Destroying of carbon tetrachloride on } \\
\text { site is important. }\end{array}$ & INEL & Regulator \\
\hline • & $\begin{array}{l}\text { Determine the recyclability of the } \\
\text { carbon tetrachloride generated by } \\
\text { membrane separation. }\end{array}$ & INEL & Interest Group \\
\hline
\end{tabular}




\begin{tabular}{|c|c|c|c|}
\hline & ISSUES BY CATEGORY & $\begin{array}{l}\text { SMES WHERE ISSUES } \\
\mathrm{R} \text { RAISED }\end{array}$ & $\begin{array}{l}\text { STAKEHOLDER } \\
\text { CATEGORIES } \\
\end{array}$ \\
\hline • & $\begin{array}{l}\text { Assess the ability to use bleed-off or } \\
\text { clean air dilution valves so that } \\
\text { variable carbon tetrachloride } \\
\text { concentrations can be equalized. }\end{array}$ & Rocky Flats & Technology User \\
\hline - & $\begin{array}{l}\text { Define the effect of ambient winter } \\
\text { temperatures on the technology, the } \\
\text { ranges of operation, and the ability to } \\
\text { operate under extremes of temperature. }\end{array}$ & $\begin{array}{ll}- & \text { INEL } \\
- & \text { Rocky Flats }\end{array}$ & $\begin{array}{ll}- & \text { Interest Group } \\
\text { - } & \text { Technology User }\end{array}$ \\
\hline • & $\begin{array}{l}\text { Evaluate the ability of the technology } \\
\text { to operate automatically with only } \\
\text { periodic checking. }\end{array}$ & INEL & Interest Group \\
\hline • & $\begin{array}{l}\text { Consider a lengthier, lower- } \\
\text { temperature condensation step, thus } \\
\text { leaving less for the membrane to act } \\
\text { on; use a heat exchange unit to recover } \\
\text { energy. }\end{array}$ & Los Alamos & Technology User \\
\hline • & $\begin{array}{l}\text { Assess methods for minimizing water } \\
\text { entrainment at the well head, which } \\
\text { may cause freezing and icing on the } \\
\text { condenser. }\end{array}$ & Rocky Flats & Technology User \\
\hline \multicolumn{4}{|c|}{ Works as Intended } \\
\hline • & $\begin{array}{l}\text { An attractive aspect of membrane } \\
\text { separation is condensation of vapor } \\
\text { into liquid. }\end{array}$ & $\begin{array}{ll}\text { - } & \text { Sandia } \\
\text { - } & \text { Rocky Flats }\end{array}$ & $\begin{array}{l}\text { Interest Group } \\
\text { Technology User }\end{array}$ \\
\hline - & $\begin{array}{l}\text { Define the range of concentrations on } \\
\text { which membrane separation } \\
\text { technology is effective; the threshold } \\
\text { of } 300 \mathrm{ppm} \text { seems too high for Sandia. }\end{array}$ & Sandia & $\begin{array}{l}\text { Interest Group } \\
\text { Technology User }\end{array}$ \\
\hline - & $\begin{array}{l}\text { Evaluate membrane separation against } \\
\text { technologies currently in use, including } \\
\text { catalytic or thermal oxidation. }\end{array}$ & $\begin{array}{ll}\text { - } & \text { Sandia } \\
\text { } & \text { Rocky Flats }\end{array}$ & $\begin{array}{ll}\text { - } & \text { Technology User } \\
\text { - Technology User }\end{array}$ \\
\hline • & $\begin{array}{l}\text { Assess the fouling of the membrane by } \\
\text { other constituents of the waste stream. }\end{array}$ & $\begin{array}{ll}- & \text { INEL } \\
- & \text { Rocky Flats }\end{array}$ & $\begin{array}{ll}- & \text { Interest Group } \\
\text { - } & \text { Technology User }\end{array}$ \\
\hline$\bullet$ & $\begin{array}{l}\text { Evaluate the membrane's ability to } \\
\text { work with possibly unidentified mixed } \\
\text { contaminants. }\end{array}$ & INEL & Interest Group \\
\hline
\end{tabular}




\begin{tabular}{|c|c|c|c|}
\hline & ISSUES BY CATEGORY & $\begin{array}{l}\text { SHYSS WHERE } \\
\text { RAISED }\end{array}$ & $\begin{array}{l}\text { STAKEHOLDER } \\
\text { CATEGORIES }\end{array}$ \\
\hline • & $\begin{array}{l}\text { Evaluate the ability of the technology } \\
\text { to work with a condenser alone, i.e., } \\
\text { with no membrane. }\end{array}$ & Rocky Flats & Technology User \\
\hline \multicolumn{4}{|c|}{ Cost } \\
\hline - & $\begin{array}{l}\text { Evaluate the total system life-cycle } \\
\text { costs, including realistic cost of } \\
\text { membranes and membrane } \\
\text { replacement, the machine, GAC } \\
\text { management, process waste } \\
\text { management and disposal, and patent } \\
\text { or licensing costs. }\end{array}$ & $\begin{array}{ll}\text { - } & \text { INEL } \\
\text { - } & \text { Los Alamos } \\
\text { - } & \text { Rocky Flats } \\
& \text { Sandia }\end{array}$ & $\begin{array}{ll}\text { - } & \text { Technology User } \\
\text { - } & \text { Regulator } \\
\text { Technology User } \\
\text { - } \quad \text { Regulator } \\
\text { - } \quad \text { Technology User } \\
\text { Interest Group } \\
\text { Regulator } \\
\text { Technology User }\end{array}$ \\
\hline - & $\begin{array}{l}\text { The technology appears to be } \\
\text { expensive, including startup costs and } \\
\text { maintenance costs. }\end{array}$ & $\begin{array}{ll}- & \text { INEL } \\
- & \text { Sandia }\end{array}$ & $\begin{array}{ll}- & \text { Technology User } \\
\text { Interest Group } \\
\text { Regulator } \\
\text { Technology User }\end{array}$ \\
\hline • & $\begin{array}{l}\text { Define the range of concentrations at } \\
\text { which the technology is cost effective; } \\
\text { it does not appear to be cost effective } \\
\text { for low concentrations. }\end{array}$ & $\begin{array}{ll}\text { - } & \text { Los Alamos } \\
\text { - Sandia }\end{array}$ & $\begin{array}{ll}\text { - } & \text { Technology User } \\
\text { - } & \text { Regulator }\end{array}$ \\
\hline - & $\begin{array}{l}\text { Evaluate the cost of the unit compared } \\
\text { to proven commercially available } \\
\text { technologies, including competing } \\
\text { technologies (PURUS, catalytic } \\
\text { oxidization, thermal oxidation, GAC) } \\
\text { at lower concentrations ( } 300 \text { to } 2000 \\
\text { ppm) }\end{array}$ & $\begin{array}{ll}\text { - } & \text { INEL } \\
\text { - } & \text { Los Alamos } \\
\text { - } & \text { Sandia } \\
& \text { Rocky Flats }\end{array}$ & $\begin{array}{ll}\text { - } & \text { Technology User } \\
& \text { Regulator } \\
\text { Technology User } \\
\text { - } \quad \text { Regulator } \\
\text { Technology User } \\
\text { - } \quad \text { Technology User }\end{array}$ \\
\hline • & $\begin{array}{l}\text { Evaluate costs of the technology } \\
\text { versus tunable hybrid plasma, which } \\
\text { appears more cost-effective. }\end{array}$ & $\begin{array}{ll}- & \text { INEL } \\
- & \text { Rocky Flats }\end{array}$ & $\begin{array}{l}\text { Regulator } \\
\text { Interest Group }\end{array}$ \\
\hline - & $\begin{array}{l}\text { Evaluate the reasons for the membrane } \\
\text { expense, including consistent materials, } \\
\text { function, and the effects of high } \\
\text { pressure. Assess the ability to recycle } \\
\text { or regenerate the membranes, and the } \\
\text { cost savings that would result. }\end{array}$ & $\begin{array}{ll}- & \text { Rocky Flats } \\
- & \text { Sandia }\end{array}$ & $\begin{array}{ll}- & \text { Regulator } \\
- & \text { Regulator }\end{array}$ \\
\hline$\bullet$ & $\begin{array}{l}\text { Evaluate power costs and include in } \\
\text { the treatment-per-unit costs. }\end{array}$ & Sandia & Technology User \\
\hline
\end{tabular}




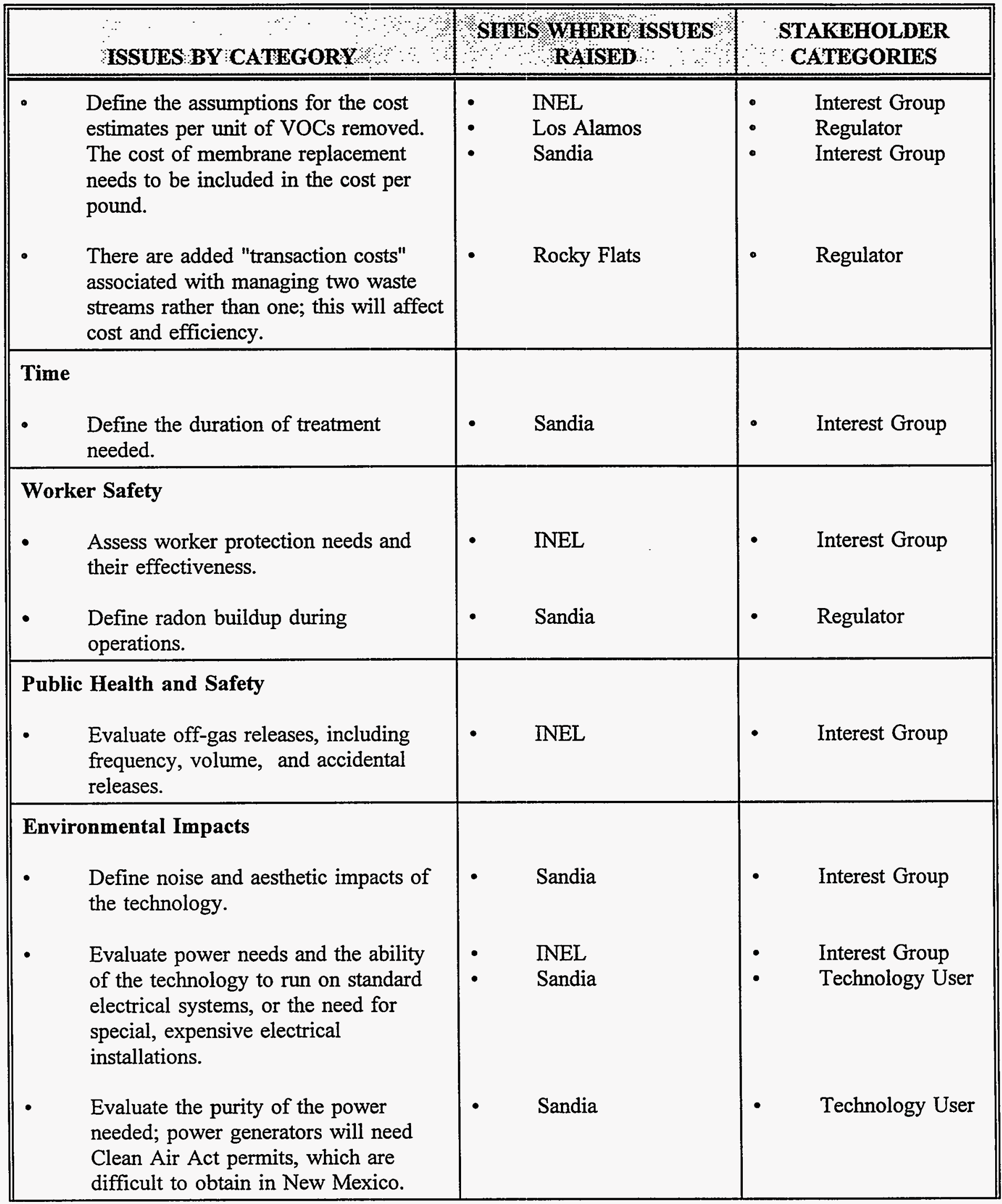




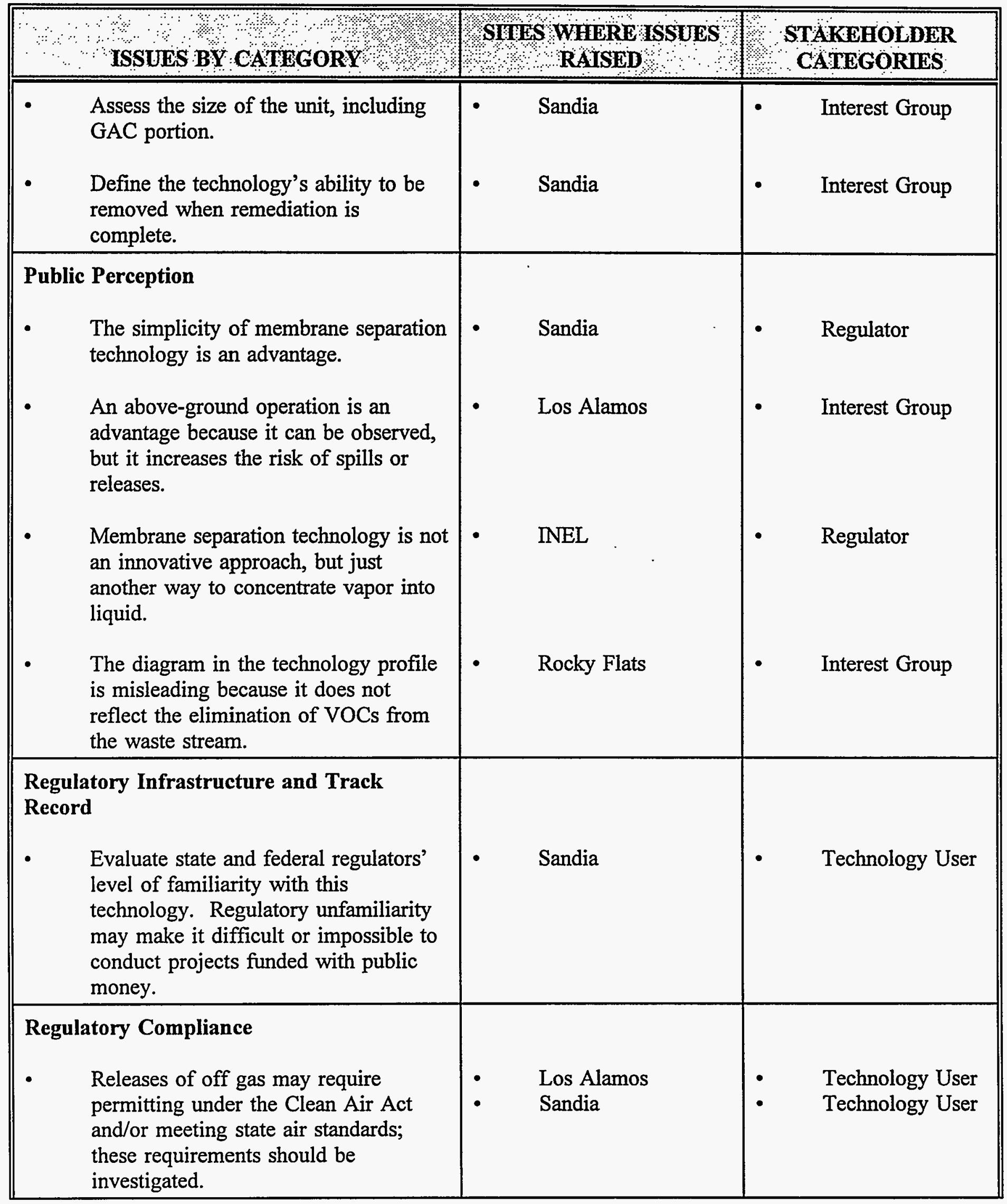




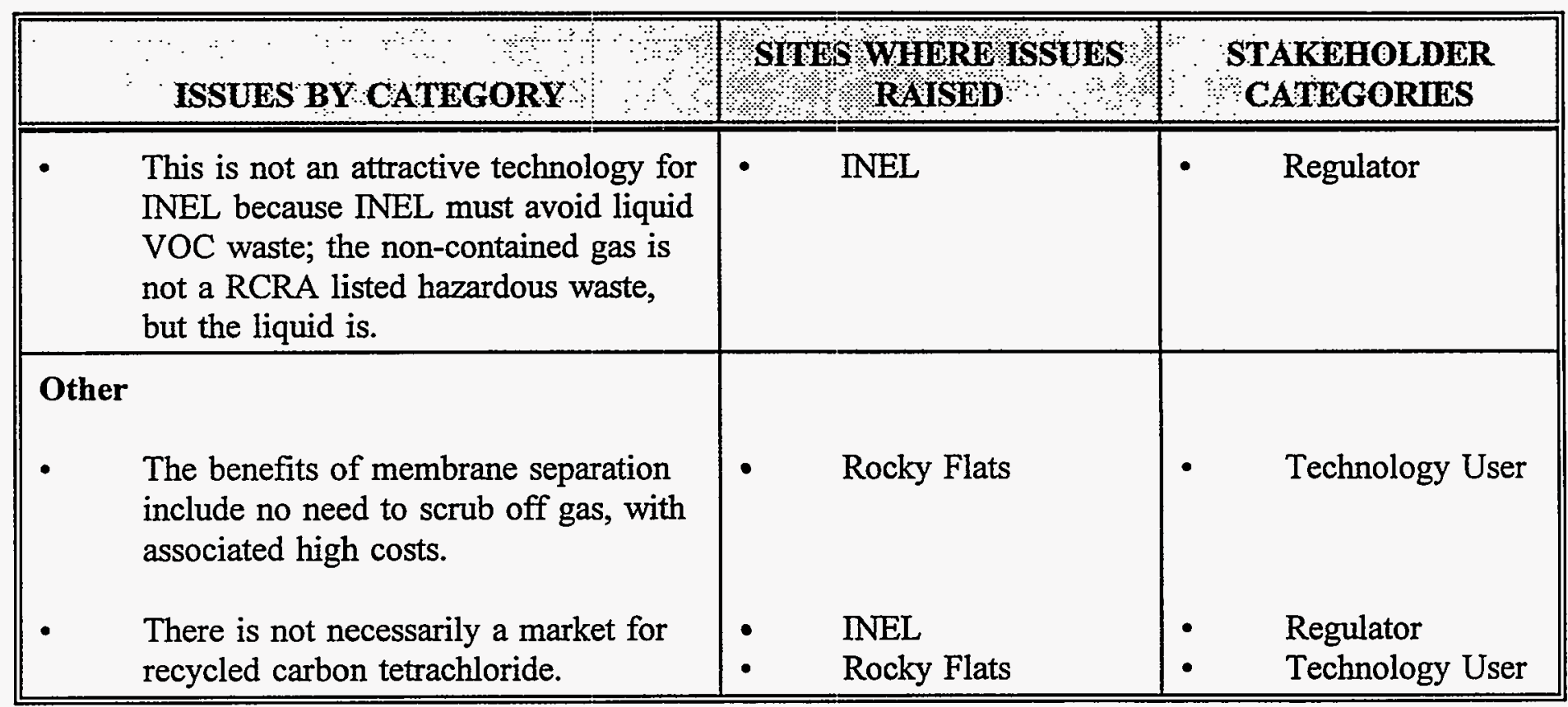




\subsection{IN-SITU BIOREMEDIATION}

In-situ bioremediation, which destroys VOCs in place, intrigued most of the stakeholders interviewed. Stakeholders provided extensive input to the technology test plan, and raised numerous issues about its demonstration and deployment. Input from Hanford stakeholders is provided in detail in the two reports cited earlier. Principal stakeholder concerns about in-situ bioremediation were in the categories of practicality, works as intended, environmental impacts, and public perception. Remaining contamination, process waste, and (at Sandia) regulatory compliance and cost, were categories that also generated a significant number of comments.

Hanford stakeholders' comments covered the same basic topics as the other arid sites. In analyzing the comments received in each issue or criterion category, the following similarities and differences are noted.

\section{$\underline{\text { Remaining Contamination }}$}

Hanford stakeholders provided no specific comments in this category. Interest group representatives, regulators, and technology users from other arid sites questioned the ability of bioremediation to remove the levels of contaminants necessary to clean the ground water. There was concern by an INEL interest group that unwanted by-products may be produced, and that acetate and nitrate may combine to make and leave something more hazardous.

\section{Process Waste}

Hanford stakeholders addressed the question of aquifer clogging with biomass, which can be defined as a process waste. Stakeholders suggested that such clogging be monitored and corrected if necessary. A range of stakeholders from the other sites requested determination of secondary products the technology may create. They also requested an analysis of the ground water oxidation chain, and whether harmful intermediate products such as chlorides, chlorine gas, and vinyl chloride will be produced.

\section{Practicality}

As with other technologies, the largest number of comments concerned practicality. Interest group representatives at Hanford were emphatic that proven failure-control mechanisms be in place before the demonstration begins. There were questions about whether the technology can be integrated with other technologies, and if it is effective with multiple contaminants, in different geologic conditions. The test plan must demonstrate the technology's destruction efficiency, its rate of action, and the limits of its effectiveness, especially as compared with the baseline pump and treat technology. A Hanford technology user questioned whether the technology can address a full range of contamination, even coming from the edge of the ground water plume, moving inward. Analysis of aquifer characteristics sufficient to proceed with in-situ bioremediation was an issue that engendered discussion, as some Hanford 
stakeholders believe that more characterization is required, and others want to proceed with cleanup. Monitoring during and after the demonstration was raised as a critical need, with specification of locations and range (e.g., surface water connected to ground water and the Columbia River). Bench-scale demonstrations using demonstration-zone microbes and soil were recommended.

INEL stakeholders raised additional issues that varied from the Hanford input. Interest group representatives and technology users viewed bioremediation as an attractive technology. It also, however, raised questions about applicability to variable soil types, such as INEL's porous rocks, and whether it would work on nitrate fertilizer problems. The ability to deliver nutrients in arid, non-sedimentary soil, fractured basalt, and the Snake River Aquifer's fastmoving water should be measured. These conditions may make it impossible to use the technology at INEL.

New Mexico stakeholders focused on the effectiveness of microbes in field conditions, with extreme temperatures, different microorganisms, different depths, and a broad range of contaminants. At Rocky Flats, those contaminants include plutonium, and there are a range of co-contaminants. Stakeholders at other sites questioned whether the technology is versatile, can be integrated with other technologies, whether it can be controlled, whether contaminants could be bioremediated at the surface, and whether specific or all microbes are stimulated.

\section{Works as Intended}

Understanding how the microbes change and how they will behave following withdrawal of nutrients was a theme at all the sites. The technology is seen, especially by technology users, as a good polishing technology, but good data are necessary on the levels of concentration, site conditions, plume size, aquifer characteristics, and permeability ranges in which bioremediation will function effectively. A tribal representative from INEL indicated that there is an advantage in using a natural process, which appears to be protective of the natural environment. An interest group representative at Rocky Flats considered it misleading to describe it as a natural process, preferring instead to consider it as an enhancement or modification of natural processes.

\section{$\underline{\text { Cost }}$}

Cost was not a major issue for stakeholders in relation to in-situ bioremediation. Hanford stakeholders want the demonstration to provide data on total costs, particularly in comparison with continued use of pump and treat technology that brings ground water to the surface. Stakeholder discussion included plans to evaluate the costs of integrating bioremediation with other treatment methods. Stakeholders from several other sites mentioned the need to assess costs per unit of VOC destroyed or removed, and to compare them with costs of comparable technologies, using the full timeframe required for the process to work. 
Time

Hanford stakeholders want the demonstration to provide data on the length of time required for the technology to work. A few stakéholders from other sites commented on the need for information on the time required to clean water to usable levels.

\section{Worker Safety}

Hanford stakeholders discussed the fact that catastrophic failure was unlikely with bioremediation, so worker safety impacts were not a major issue. One technology user at Sandia requested information on the training needed in order to ensure that operators adequately monitor the bioremediation system.

\section{$\underline{\text { Public Health and Safety }}$}

Hanford stakeholders stressed the importance of understanding how the microbes would work during and after stimulation, so that any effect on human health could be detected. Plans for stopping the microbial growth were of major concern. Several comments on public health and safety were received from stakeholders at the other sites as well, focusing on the types of nutrients injected, controls and monitoring mechanisms, and the effect on humans from ingesting the microbes. A Sandia technology user indicated that in-situ treatment is an advantage, due to reduced potential exposures, elimination of transportation, and reduced treatment and disposal costs. A Rocky Flats technology user asked that the demonstration assess whether microbes may cause spreading of contamination, a major concern at that site.

\section{Environmental Impacts}

Hanford stakeholders expressed concern about impacts of the microbes on biota, especially in the Columbia River. Again, control of the microbes was a significant issue. Short and longterm effects on aquifer permeability were a concern as well. Stakeholders from other sites expressed similar concerns, including a suggestion from an INEL interest group representative that the demonstration be conducted completely contained above ground to avoid losing control of microbes. Stakeholders registered concern about the technology's potential for contamination and about adding nitrates to ground water, especially in New Mexico where some ground water in the Albuquerque area is high in nitrates. Ground-water quality impacts were a significant concern at all the arid sites. Stakeholders questioned the technology's potential to negatively affect drinking water sources.

\section{$\underline{\text { Public Perception }}$}

Hanford stakeholders discussed independent, third-party review as contributing to public confidence in the characterization required before the technology is applied. There are concerns about too little as well as too much characterization at Hanford, with stakeholders divided in their perceptions. They also suggested independent review of the demonstration's 
results to add to public confidence in the technology's deployment. (Though these comments arose in discussion of in-situ bioremediation, they were noted as applying to other innovative technologies as well.) Although there are public concerns about the types and control of the microbes, there will not necessarily be an alarmed public reaction to the technology. It was seen as having potential advantages that should be clearly compared with baseline technologies.

Stakeholders at other arid sites had mixed opinions about the acceptability of in-situ bioremediation. An INEL regulator indicated that the public does not want anything added to an ecosystem, so it must be demonstrated that the additives are only at minimal levels needed to effect cleanup. It is hard to demonstrate to people what they cannot see; confidence may be raised by independent review, according to a New Mexico interest group. Some stakeholders see bioremediation as a natural process, others as a perturbation of a natural process.

\section{Tribal Rights and Future Land Uses}

Tribes associated with Hanford are emphatic about eventually returning the land to pristine condition. This tribal value must be considered both in use of the technology and in demonstrating no long-term negative effects on the aquifer. A tribal representative associated with INEL indicated that bioremediation is a natural process that appears to be protective of the natural environment.

\section{$\underline{\text { Socio-Economic Interests }}$}

No specific comments were received in this category.

\section{Compatibility with Cleanup Milestones}

Hanford stakeholders mentioned that regulatory acceptance of in-situ bioremediation may be enhanced because the technology would accelerate progress toward meeting mandated cleanup milestones. No specific comments were received from the other arid sites.

\section{$\underline{\text { Regulatory Infrastructure and Track Record }}$}

No specific comments were received in this category.

\section{$\underline{\text { Regulatory Compliance }}$}

In Washington, the state regulatory agency will have a problem with injecting anything but oxygen to stimulate microbial growth, since there is a non-degradation standard for ground water. Test plans must demonstrate the mobility and health impacts of anything added to the subsurface. At the other arid sites, input addressed the need to meet regulatory standards for drinking water and assess the ability to meet regulatory cleanup standards. A Sandia 
technology user pointed out that New Mexico regulators will not permit injection of anything into ground water, so those specific regulatory requirements would need to be further investigated.

Table 4 on the following pages summarizes comments on in-situ bioremediation received from stakeholders at the other arid sites, organized by criterion category. 


\begin{tabular}{|c|c|c|c|}
\hline & ISSUES BY CATEGORO & $\begin{array}{l}\text { STTES WHERE ISSUES } \\
\text { RAISED }\end{array}$ & $\begin{array}{l}\text { STAKEHOLDER } \\
\text { CATEGORIES }\end{array}$ \\
\hline \multicolumn{4}{|c|}{ Remaining Contamination } \\
\hline & $\begin{array}{l}\text { Determine the environmental } \\
\text { ramifications of the use of acetate, } \\
\text { including the effects on } \mathrm{pH} \text {, metal } \\
\text { mobility and redox potential, and } \\
\text { reactions of acetate and nitrate that } \\
\text { might make something in the aquifer } \\
\text { more hazardous. }\end{array}$ & $\begin{array}{ll}- & \text { INEL } \\
\text { - } & \text { Sandia }\end{array}$ & $\begin{array}{ll}\text { - } & \text { Interest Group } \\
\text { Regulator }\end{array}$ \\
\hline - & $\begin{array}{l}\text { Assess how biomass affects organic } \\
\text { and inorganic co-contaminants and } \\
\text { pesticides (range of concentrations), } \\
\text { and whether it metabolizes metals or } \\
\text { changes their valence state. }\end{array}$ & - $\quad$ Sandia & Regulator \\
\hline • & $\begin{array}{l}\text { Assess the efficiency of the } \\
\text { technology. Define its ability to } \\
\text { handle the total contamination } \\
\text { problem, including radionuclides and } \\
\text { metals, and define performance levels. }\end{array}$ & $\begin{array}{ll}\text { - } & \text { Sandia } \\
\text { - } & \text { Rocky Flats }\end{array}$ & $\begin{array}{l}\text { Interest Group } \\
\text { Technology User } \\
\text { Interest Group } \\
\text { Technology User }\end{array}$ \\
\hline • & $\begin{array}{l}\text { Define any restrictions on future } \\
\text { ground water use. }\end{array}$ & Sandia & Interest Group \\
\hline \multicolumn{4}{|c|}{ Process Waste } \\
\hline & $\begin{array}{l}\text { Evaluate the possibility that the action } \\
\text { of the stimulated microorganisms will } \\
\text { produce unwanted by-products. } \\
\text { Determine the quantities and types of } \\
\text { degradation products, both anticipated } \\
\text { and unanticipated, and their potential } \\
\text { environmental impacts. }\end{array}$ & $\begin{array}{ll}- & \text { INEL } \\
\text { - } & \text { Los Alamos } \\
\text { - } & \text { Rocky Flats } \\
\text { - } & \text { Sandia }\end{array}$ & $\begin{array}{ll}- & \text { Interest Group } \\
\text { - } & \text { Technology User } \\
\text { - } & \text { Regulator } \\
& \text { Technology User } \\
\text { Interest Group } \\
\quad & \text { Regulator }\end{array}$ \\
\hline & $\begin{array}{l}\text { Evaluate the secondary waste, } \\
\text { including biomass, produced from } \\
\text { microbial digestion of carbon } \\
\text { tetrachloride. }\end{array}$ & $\begin{array}{ll}- & \text { Los Alamos } \\
\text { - } & \text { Rocky Flats } \\
& \text { Sandia }\end{array}$ & $\begin{array}{ll}\text { - } & \text { Interest Group } \\
\text { - } & \text { Regulator } \\
\text { Interest Group }\end{array}$ \\
\hline & $\begin{array}{l}\text { Evaluate approaches to prevent } \\
\text { microbial waste products from } \\
\text { eventually shutting down the system. }\end{array}$ & Sandia & Technology User \\
\hline
\end{tabular}




\begin{tabular}{|c|c|c|}
\hline ISSUES BY: CATEGORY $\cdots$ & $\begin{array}{l}\text { SITES WHERE ISSUES } \\
\text { RAISED }\end{array}$ & $\begin{array}{l}\text { STAKEHOLDER } \\
\text { CATEGORIES }\end{array}$ \\
\hline \multicolumn{3}{|l|}{ Practicality } \\
\hline $\begin{array}{l}\text { In-situ techniques are preferable to } \\
\text { bringing contamination to a well or } \\
\text { withdrawal system. The benefit of this } \\
\text { technology is its ability to handle } \\
\text { contaminants that pump and treat } \\
\text { cannot fully address. }\end{array}$ & $\begin{array}{ll}\text { - } & \text { INEL } \\
\text { - } & \text { Los Alamos }\end{array}$ & $\begin{array}{l}\text { Interest Group } \\
\text { Technology User } \\
\text { Technology User }\end{array}$ \\
\hline $\begin{array}{l}\text { Evaluate the usefulness and } \\
\text { applicability of this technology for a } \\
\text { broad range of applications and } \\
\text { conditions including: a range of } \\
\text { constituents; co-contaminants; various } \\
\text { soil types and geologies; the ability to } \\
\text { function in the vadose zone, in } \\
\text { different weather conditions, and in } \\
\text { plutonium-contaminated zones. }\end{array}$ & $\begin{array}{ll}- & \text { INEL } \\
\text { - } & \text { Los Alamos } \\
& \text { Rocky Flats } \\
& \\
\text { - } & \text { Sandia }\end{array}$ & $\begin{array}{ll}- & \text { Interest Group } \\
\text { - } & \text { Technology User } \\
\text { Interest Group } \\
\text { Regulator } \\
\text { Technology User } \\
\text { Interest Group } \\
\text { Technology User }\end{array}$ \\
\hline $\begin{array}{l}\text { Address the technology's ability to } \\
\text { work in changing aquifer } \\
\text { characteristics and transmissivity } \\
\text { characteristics, and to address } \\
\text { subsurface aquifer discontinuities. }\end{array}$ & Sandia & Regulator \\
\hline $\begin{array}{l}\text { Evaluate and document failure } \\
\text { scenarios. }\end{array}$ & INEL & Interest Group \\
\hline $\begin{array}{l}\text { Evaluate the potential for entrainment } \\
\text { of metals and particulates (including } \\
\text { radioactively contaminated } \\
\text { particulates) and the ability to } \\
\text { concentrate dispersed plutonium. }\end{array}$ & Rocky Flats & $\begin{array}{l}\text { Interest Group } \\
\text { Technology User }\end{array}$ \\
\hline $\begin{array}{l}\text { Evaluate needed nutrient balances in } \\
\text { different conditions. Evaluate the } \\
\text { ability to supply nutrients when } \\
\text { microbes sorb onto soil particles and } \\
\text { the ability to deliver nutrients in arid } \\
\text { climates, non-sedimentary materials, } \\
\text { and fast-moving subsurface ground } \\
\text { water. }\end{array}$ & INEL & $\begin{array}{l}\text { Regulator } \\
\text { Technology User }\end{array}$ \\
\hline
\end{tabular}




\begin{tabular}{|c|c|c|}
\hline ISSUES BY YCATEGORY & $\begin{array}{l}\text { STTES WHERE ISSUES } \\
\text { RAISED }\end{array}$ & $\begin{array}{l}\text { STAKEHOLDER } \\
\text { CATEGORIES }\end{array}$ \\
\hline $\begin{array}{l}\text { Determine the requirements for } \\
\text { nutrients, oxygen, and temperature, } \\
\text { and assess the likelihood of getting } \\
\text { microbes to live in field conditions. } \\
\text { Evaluate the ability to couple aerobic } \\
\text { with anaerobic bioremediation to } \\
\text { address all contaminants. }\end{array}$ & $\begin{array}{ll}- & \text { Los Alamos } \\
\text { - } & \text { Sandia }\end{array}$ & $\begin{array}{l}\text { Technology User } \\
\text { Interest Group }\end{array}$ \\
\hline $\begin{array}{l}\text { Define the genus and class of native } \\
\text { microorganisms that will be stimulated } \\
\text { and the expected effects of stimulation. } \\
\text { Evaluate the broad applicability of the } \\
\text { technology to sites with different } \\
\text { climates and populations of } \\
\text { microorganisms. Culture soils and/or } \\
\text { ground-water samples in advance to } \\
\text { ascertain that the microbes needed for } \\
\text { the chemicals of concern are present. }\end{array}$ & $\begin{array}{ll}\text { - } & \text { INEL } \\
\text { - } & \text { Los Alamos } \\
& \text { Rocky Flats }\end{array}$ & $\begin{array}{l}\text { Technology User } \\
\text { Regulator } \\
\text { Technology User } \\
\text { Interest Group } \\
\text { Regulator }\end{array}$ \\
\hline $\begin{array}{l}\text { Consider using bioengineered } \\
\text { specialized microbes, rather than } \\
\text { native microorganisms. }\end{array}$ & $\begin{array}{ll}- & \text { INEL } \\
\text { - } & \text { Los Alamos } \\
\text { - } & \text { Rocky Flats }\end{array}$ & $\begin{array}{ll}- & \text { Technology User } \\
\text { - } & \text { Technology User } \\
\text { Regulator }\end{array}$ \\
\hline $\begin{array}{l}\text { Evaluate monitoring techniques to } \\
\text { verify coverage and effectiveness of } \\
\text { the technology in an heterogeneous } \\
\text { subsurface. }\end{array}$ & INEL & Technology User \\
\hline $\begin{array}{l}\text { Assess whether the technology reduces } \\
\text { soil permeability. }\end{array}$ & Rocky Flats & Technology User \\
\hline $\begin{array}{l}\text { Assess the ability to control the growth } \\
\text { and spread of microorganisms. }\end{array}$ & Rocky Flats & Technology User \\
\hline $\begin{array}{l}\text { Consider using horizontal wells rather } \\
\text { than vertically-oriented wells. }\end{array}$ & Los Alamos & Technology User \\
\hline $\begin{array}{l}\text { Define the number of holes required to } \\
\text { get enough nutrients down to ground } \\
\text { water. Determine how to prevent } \\
\text { surface contamination from washing } \\
\text { down holes. }\end{array}$ & Los Alamos & Tribes \\
\hline
\end{tabular}




\begin{tabular}{|c|c|c|c|}
\hline & ISSUES BY CATEGORY & $\begin{array}{l}\text { SICES WHERE ISSUES } \\
\text { RAISED }\end{array}$ & $\begin{array}{l}\text { STAKEHOLDER } \\
\text { CATEGORIES }\end{array}$ \\
\hline - & $\begin{array}{l}\text { Evaluate the ability to operate in a } \\
\text { pulsed fashion and in a quasi-closed } \\
\text { loop system, with inputs (bio- } \\
\text { stimulants) equaling output, so that } \\
\text { ground-water mounding does not } \\
\text { occur. }\end{array}$ & $\begin{array}{ll}- & \text { Sandia } \\
\text { - } & \text { Los Alamos }\end{array}$ & $\begin{array}{ll}- & \text { Regulator } \\
\text { - } & \text { Technology User }\end{array}$ \\
\hline - & $\begin{array}{l}\text { Evaluate the usefulness of the } \\
\text { technology for near-surface ground- } \\
\text { water cleanup. }\end{array}$ & Sandia & Regulator \\
\hline - & $\begin{array}{l}\text { Does the potential effect of biomass } \\
\text { slowing ground-water flow and } \\
\text { stabilizing contamination preclude } \\
\text { other treatments later? }\end{array}$ & Sandia & Regulator \\
\hline - & $\begin{array}{l}\text { Consider opening up the subsurface } \\
\text { geology to allow the movement of } \\
\text { stimulated microorganisms. }\end{array}$ & Rocky Flats & Interest Group \\
\hline - & $\begin{array}{l}\text { Benzene is a primary concern at } \\
\text { Rocky Mountain Arsenal. Define } \\
\text { whether there is a need to add both } \\
\text { nitrates for in-situ bioremediation to } \\
\text { function effectively. }\end{array}$ & Rocky Flats & Regulator \\
\hline - & $\begin{array}{l}\text { Assess bringing waste to the surface } \\
\text { and using the technology where it } \\
\text { could be observed and controlled. }\end{array}$ & Rocky Flats & Technology User \\
\hline - & $\begin{array}{l}\text { Injection and withdrawal wells may be } \\
\text { needed at Rocky Flats to create a } \\
\text { predictable flow pattern in clay soils. }\end{array}$ & Rocky Flats & Technology User \\
\hline • & $\begin{array}{l}\text { Assess whether this technology creates } \\
\text { a reduction zone at the edge of } \\
\text { plumes, making metals more soluble. } \\
\text { Selenium is a problem at Rocky Flats. }\end{array}$ & Rocky Flats & Technology User \\
\hline - & $\begin{array}{l}\text { Can the technology be used with other } \\
\text { technologies (e.g., air stripper, pump } \\
\text { and treat)? }\end{array}$ & Rocky Flats & Technology User \\
\hline
\end{tabular}




\begin{tabular}{|c|c|c|}
\hline ISSUES BY CATEGORY & $\begin{array}{l}\text { SITES WHERE ISSUES } \\
\text { RAISED } \\
\end{array}$ & $\begin{array}{l}\text { STAKEHOLDER } \\
\text { CATEGORIES }\end{array}$ \\
\hline $\begin{array}{l}\text { Define skill levels and assess the level } \\
\text { of specialized training needed to } \\
\text { operate the technology. }\end{array}$ & $\begin{array}{ll}- & \text { Rocky Flats } \\
\text { - } & \text { Sandia }\end{array}$ & $\begin{array}{ll}\text { - } & \text { Technology User } \\
\text { - } & \text { Interest Group }\end{array}$ \\
\hline $\begin{array}{l}\text { Evaluate the effectiveness of using in- } \\
\text { situ bioremediation first, and then } \\
\text { using other technologies as polishing } \\
\text { approaches. }\end{array}$ & Sandia & Technology User \\
\hline $\begin{array}{l}\text { This technology is not useful at Sandia } \\
\text { due to the depth of ground water and } \\
\text { the fact the most contamination is now } \\
\text { in the vadose zone. }\end{array}$ & Sandia & Technology User \\
\hline \multicolumn{3}{|l|}{ Works as Intended } \\
\hline $\begin{array}{l}\text { - Assess the effects of solvent toxicity } \\
\text { on microbes. }\end{array}$ & INEL & Regulator \\
\hline $\begin{array}{l}\text { Consider the need for a site-specific } \\
\text { system design to accommodate } \\
\text { differing strata and the nature of } \\
\text { contamination. }\end{array}$ & INEL & Regulator \\
\hline $\begin{array}{l}\text { It is unclear how microbes would stay in } \\
\text { fractured basalt at depth at INEL. }\end{array}$ & - $\quad$ INEL & Regulator \\
\hline $\begin{array}{l}\text { This appears to be a good polishing } \\
\text { technology. Evaluate the upper limits of } \\
\text { concentrations the technology can handle } \\
\text { (potential application to tank sludge to } \\
\text { remove RCRA regulated organics and } \\
\text { leave radionuclides only). }\end{array}$ & $\mathbb{I N E L}$ & Technology User \\
\hline Identify the lower limits of effectiveness. & Rocky Flats & Technology User \\
\hline $\begin{array}{l}\text { Evaluate characterization needs and levels, } \\
\text { including the effects of encountering } \\
\text { unexpected contaminants or concentrations } \\
\text { on effectiveness. Evaluate the effects of } \\
\text { geology in order to know if organisms } \\
\text { will spread to targeted areas. }\end{array}$ & $\begin{array}{ll}\text { - } & \text { INEL } \\
\text { Rocky Flats }\end{array}$ & $\begin{array}{ll}- & \text { Technology User } \\
\text { Interest Group } \\
\text { Public Official }\end{array}$ \\
\hline $\begin{array}{l}\text { Evaluate the zone of influence and the } \\
\text { maximum area possible for treatment with } \\
\text { this technology. Evaluate the usefulness } \\
\text { of the technology for large plumes versus } \\
\text { limited areas of contamination. }\end{array}$ & $\begin{array}{ll}: & \text { INEL } \\
: & \text { Los Alamos } \\
\text { Sandia }\end{array}$ & $\begin{array}{ll}- & \text { Tribes } \\
\text { - } & \text { Technology User } \\
\text { Public Official } \\
\text { Regulator } \\
\text { Technology User } \\
\text { Tribes } \\
\end{array}$ \\
\hline
\end{tabular}




\begin{tabular}{|c|c|c|c|}
\hline & ISSUES BY CATEGORY & $\begin{array}{c}\text { SITES WHERE ISSUES } \\
\text { RAISED }\end{array}$ & $\begin{array}{l}\text { STAKEHOLDER } \\
\text { CATEGORIES }\end{array}$ \\
\hline - & $\begin{array}{l}\text { Evaluate aquifer flow restrictions, } \\
\text { particularly as the technology may affect } \\
\text { spring flows. Determine aquifer } \\
\text { permeability ranges for effective nutrient } \\
\text { delivery, and the potential for preferential } \\
\text { direction of the distribution of the biomass } \\
\text { by aquifer characteristics. }\end{array}$ & $\begin{array}{ll}\cdot & \text { INEL } \\
\cdot & \text { Los Alamos } \\
\cdot & \text { Sandia }\end{array}$ & $\begin{array}{l}\text { Technology User } \\
\text { Regulator } \\
\text { Interest Group }\end{array}$ \\
\hline - & $\begin{array}{l}\text { Assess the technology's ability to treat } \\
\text { heterogeneous contamination. }\end{array}$ & Los Alamos & Interest Group \\
\hline - & $\begin{array}{l}\text { Assess the ability of the technology to } \\
\text { operate effectively and provide detailed } \\
\text { input/output analysis. }\end{array}$ & $\begin{array}{ll}- & \text { Sandia } \\
- & \text { Rocky Flats }\end{array}$ & $\begin{array}{l}\text { Technology User } \\
\text { Interest Group }\end{array}$ \\
\hline - & $\begin{array}{l}\text { Determine the methods for delivering } \\
\text { nutrients at different distances from the } \\
\text { wells. Quantify how air bubbles move in } \\
\text { the aquifer in order to appropriately } \\
\text { design the technology. }\end{array}$ & Los Alamos & Regulator \\
\hline - & $\begin{array}{l}\text { In-situ bioremediation's effectiveness has } \\
\text { not been proven with lower-carbon-chain } \\
\text { contaminants. }\end{array}$ & Rocky Flats & Regulator \\
\hline - & $\begin{array}{l}\text { Assess the ability to control the vertical } \\
\text { distribution of microbes. }\end{array}$ & Sandia & Regulator \\
\hline • & $\begin{array}{l}\text { Assess the potential for ground water } \\
\text { mounding at the treated area. }\end{array}$ & Sandia & Technology User \\
\hline - & $\begin{array}{l}\text { Develop consistent coefficients and } \\
\text { theories of action for the technology. }\end{array}$ & Sandia & Technology User \\
\hline • & $\begin{array}{l}\text { Ensure that there are enough wells to } \\
\text { avoid dead spots and small anaerobic } \\
\text { areas, which will compromise the } \\
\text { effectiveness of the technology. }\end{array}$ & Sandia & Technology User \\
\hline
\end{tabular}




\begin{tabular}{|c|c|c|c|}
\hline & ISSUES BY CATEGORY & $\begin{array}{l}\text { SITES WHERE ISSUES } \\
\text { RAISED }\end{array}$ & $\begin{array}{l}\text { STAKEHOLDER } \\
\text { CATEGORIES }\end{array}$ \\
\hline \multicolumn{4}{|c|}{ Cost } \\
\hline - & $\begin{array}{l}\text { Evaluate system costs before full-scale } \\
\text { testing, including startup costs and } \\
\text { operating costs for the timeframe required } \\
\text { for the process to work. }\end{array}$ & $\begin{array}{ll}\cdot & \text { INEL } \\
\cdot & \text { Sandia }\end{array}$ & $\begin{array}{l}\text { Interest Group } \\
\text { Interest Group } \\
\text { Public Official }\end{array}$ \\
\hline • & $\begin{array}{l}\text { Evaluate in-situ bioremediation's cost } \\
\text { competiveness with technologies } \\
\text { performing similar functions, including } \\
\text { pump and treat. }\end{array}$ & $\begin{array}{ll}\text { - } & \text { Los Alamos } \\
\text { Sandia }\end{array}$ & $\begin{array}{l}\text { Regulator } \\
\text { Interest Group }\end{array}$ \\
\hline • & $\begin{array}{l}\text { Define costs per unit of contaminant } \\
\text { treated or destroyed. These costs appear } \\
\text { to be low, thus making the technology's } \\
\text { use appropriate for small businesses. }\end{array}$ & Sandia & $\begin{array}{l}\text { Interest Group } \\
\text { Technology User }\end{array}$ \\
\hline - & The system costs seem expensive. & Sandia & Public Official \\
\hline - & Startup costs appear to be minimal. & Sandia & Technology User \\
\hline \multicolumn{4}{|c|}{ Time } \\
\hline - & $\begin{array}{l}\text { Define the timeframe to complete cleanup } \\
\text { of ground water to usable levels. Can the } \\
\text { water be used during treatment? }\end{array}$ & $\begin{array}{ll}\text { - } & \text { Los Alamos } \\
\text { Sandia }\end{array}$ & $\begin{array}{ll}- & \text { Public Official } \\
\text { Interest Group } \\
\text { Technology User }\end{array}$ \\
\hline$\bullet$ & $\begin{array}{l}\text { Evaluate the duration of the microbe } \\
\text { bloom and die-back phases. }\end{array}$ & Sandia & Technology User \\
\hline \multicolumn{4}{|c|}{ Worker Safety } \\
\hline$\bullet^{\bullet}$ & $\begin{array}{l}\text { Define needs for operator training to } \\
\text { adequately monitor the system. }\end{array}$ & Sandia & Technology User \\
\hline
\end{tabular}




\begin{tabular}{|c|c|c|c|}
\hline & ISSUES BY CATEGORY & $\begin{array}{c}\text { SITES WHERE ISSUES } \\
\text { RAISED }\end{array}$ & $\begin{array}{l}\text { STAKEHOLDER } \\
\text { CATEGORIES }\end{array}$ \\
\hline \multicolumn{4}{|c|}{ Public Health and Safety } \\
\hline - & $\begin{array}{l}\text { Define controls for excess microbial } \\
\text { growth and controls to ensure that the } \\
\text { appropriate organisms are stimulated. }\end{array}$ & Rocky Flats & Interest Group \\
\hline • & $\begin{array}{l}\text { Evaluate the ability to monitor the } \\
\text { technology, and to demonstrate that } \\
\text { contaminants are not spreading and } \\
\text { escaping from the treatment area. }\end{array}$ & Rocky Flats & Technology User \\
\hline • & $\begin{array}{l}\text { Define the microbes more clearly, and } \\
\text { assess the potential impacts on humans if } \\
\text { the microbes are ingested. }\end{array}$ & Sandia & Public Official \\
\hline - & $\begin{array}{l}\text { Subsurface or in-situ treatment is an } \\
\text { advantage due to reduced potential } \\
\text { exposures, elimination of transportation, } \\
\text { and reduced treatment and disposal costs. }\end{array}$ & Sandia & Technology User \\
\hline
\end{tabular}




\begin{tabular}{|c|c|c|c|}
\hline & ISSUES BY CATEGORY & $\begin{array}{l}\text { SITES WHERE ISSUES } \\
\text { RAISED }\end{array}$ & $\begin{array}{l}\text { STAKEHOLDER } \\
\text { CATEGORIES }\end{array}$ \\
\hline \multicolumn{4}{|c|}{ Environmental Impacts } \\
\hline - & $\begin{array}{l}\text { Define the environmental impacts of the } \\
\text { technology's use, including the impacts of } \\
\text { creating abnormal conditions and } \\
\text { potentially spreading contamination. } \\
\text { Assess whether that affected section of the } \\
\text { ecosystem will impact other sections. }\end{array}$ & - Rocky Flats & $\begin{array}{l}\text { Interest Group } \\
\text { Technology User }\end{array}$ \\
\hline - & $\begin{array}{l}\text { Assess the ability to stimulate specific } \\
\text { microbes and to control the growth of } \\
\text { microorganisms. Consider above-ground, } \\
\text { controlled use in } 100 \% \text { containment. }\end{array}$ & $\begin{array}{ll}\text { - } & \text { INEL } \\
\text { Rocky Flats }\end{array}$ & $\begin{array}{l}\text { Interest Group } \\
\text { Interest Group }\end{array}$ \\
\hline • & $\begin{array}{l}\text { Evaluate whether radionuclides could } \\
\text { affect microbial growth and cause escapes. }\end{array}$ & - & - \\
\hline - & $\begin{array}{l}\text { Define the effects of acetate on ground } \\
\text { water. }\end{array}$ & Rocky Flats & Public Official \\
\hline - & $\begin{array}{l}\text { Evaluate the effects of the technology, } \\
\text { including long-term effects, on } \\
\text { permeability and flow conditions of an } \\
\text { aquifer and on water quality. Will side } \\
\text { effects on the ground water interrupt } \\
\text { natural processes? }\end{array}$ & $\begin{array}{l}\text { - } \\
\text { - } \quad \text { Sandia }\end{array}$ & $\begin{array}{l}\text { Interest Group } \\
\text { Regulator } \\
\text { Technology User } \\
\text { Interest Group } \\
\text { Public Official }\end{array}$ \\
\hline - & $\begin{array}{l}\text { Evaluate microbial growth in ground } \\
\text { water and the area of effectiveness. Could } \\
\text { water treated by this method be used for } \\
\text { irrigation or drinking? What would the } \\
\text { requirements be for filtration or processing } \\
\text { water treated by bioremediation? }\end{array}$ & $\begin{array}{l}\text { - } \quad \text { Los Alamos } \\
\text { - } \quad \text { Sandia }\end{array}$ & $\begin{array}{l}\text { Regulator } \\
\text { Tribes } \\
\text { Interest Group } \\
\text { Public Official } \\
\text { Technology User }\end{array}$ \\
\hline • & $\begin{array}{l}\text { The technology is likely to spread } \\
\text { contamination in INEL conditions. }\end{array}$ & INEL & Regulator \\
\hline - & $\begin{array}{l}\text { Evaluate the buildup of nitrates in ground } \\
\text { water, and possible mechanisms to } \\
\text { monitor and control the buildup. There is } \\
\text { concern about creating another cleanup } \\
\text { problem by adding nitrates. }\end{array}$ & $\begin{array}{ll}\text { - } & \text { INEL } \\
\text { - } & \text { Los Alamos }\end{array}$ & $\begin{array}{l}\text { Regulator } \\
\text { Interest Group } \\
\text { Public Official } \\
\text { Regulator } \\
\text { Tribes }\end{array}$ \\
\hline$\bullet$ & $\begin{array}{l}\text { Use of native microbes is an advantage; } \\
\text { don't import "exotic" species. }\end{array}$ & Los Alamos & Interest Group \\
\hline
\end{tabular}




\begin{tabular}{|c|c|c|c|}
\hline & ISSUES BY CATEGORY & $\begin{array}{c}\text { SITES WHERE ISSUES } \\
\text { RAISED }\end{array}$ & $\begin{array}{l}\text { STAKEHOLDER } \\
\text { CATEGORIES }\end{array}$ \\
\hline - & $\begin{array}{l}\text { Evaluate the relationship of selected } \\
\text { microbes to other microbes in the area. }\end{array}$ & Sandia & Regulator \\
\hline - & $\begin{array}{l}\text { Evaluate whether the microbes stop } \\
\text { growing when nutrient addition ends. } \\
\text { Evaluate how microbes behave with } \\
\text { indigenous food sources. }\end{array}$ & Sandia & Regulator \\
\hline - & $\begin{array}{l}\text { Evaluate the effects of the technology at } \\
\text { the discharge point and the possible } \\
\text { creation of an imbalanced ecosystem. }\end{array}$ & Los Alamos & Technology User \\
\hline - & $\begin{array}{l}\text { Define the size and footprint of necessary } \\
\text { equipment at the surface. }\end{array}$ & Sandia & Interest Group \\
\hline - & $\begin{array}{l}\text { Assess the tendency of the technology to } \\
\text { create a reducing environment (wherein } \\
\text { electrons are being added to ions), and the } \\
\text { likelihood of increased inorganic } \\
\text { contaminant mobility. Evaluate } \\
\text { dissolution and precipitation of metals and } \\
\text { biofouling of the well and aquifer in the } \\
\text { vicinity of the well screen. }\end{array}$ & Sandia & Regulator \\
\hline - & $\begin{array}{l}\text { Define monitoring requirements for } \\
\text { growth and spread of microorganisms. } \\
\text { How will degradation of contaminants be } \\
\text { measured? }\end{array}$ & Rocky Flats & $\begin{array}{l}\text { Regulator } \\
\text { Interest Group }\end{array}$ \\
\hline - & Evaluate creation of by-products. & Rocky Flats & Technology User \\
\hline - & $\begin{array}{l}\text { Assess differences over time (e.g., } \\
\text { increased biomass) with microbial growth } \\
\text { in saturated soil. }\end{array}$ & Sandia & Interest Group \\
\hline • & $\begin{array}{l}\text { Evaluate the likelihood of releasing } \\
\text { product into free phase and causing it to } \\
\text { move into ground water as free product. }\end{array}$ & Sandia & Regulator \\
\hline \multicolumn{4}{|c|}{ Public Perception } \\
\hline - & $\begin{array}{l}\text { Potential clogging of the aquifer with } \\
\text { biomass and slowing ground water flow } \\
\text { will be the public perception problems at } \\
\text { INEL. Evaluate the potential impacts on } \\
\text { aquifer quality and quantity. }\end{array}$ & INEL & Interest Group \\
\hline
\end{tabular}




\begin{tabular}{|c|c|c|}
\hline ISSUES BY CATEGORY & $\begin{array}{l}\text { SITES WHERE ISSUES } \\
\text { RAISED }\end{array}$ & $\begin{array}{l}\text { STAKEHOLDER } \\
\text { CATEGORIES }\end{array}$ \\
\hline $\begin{array}{l}\text { Information is generally available about } \\
\text { this technology. This provides a context } \\
\text { and makes people somewhat more } \\
\text { comfortable with it. }\end{array}$ & INEL & Interest Group \\
\hline $\begin{array}{l}\text { This technology is not really natural; there } \\
\text { is experience with the public not wanting } \\
\text { anything added to the natural ecosystem. } \\
\text { Demonstrate that the additives are only at } \\
\text { necessary levels. }\end{array}$ & INEL & Regulator \\
\hline $\begin{array}{l}\text { Because it is a natural process, public } \\
\text { perception may be positive. Consider use } \\
\text { of the technology as a preventive } \\
\text { technique. }\end{array}$ & Sandia & Interest Group \\
\hline $\begin{array}{l}\text { Deployment would require a local } \\
\text { education program using local resources. }\end{array}$ & Sandia & Regulator \\
\hline $\begin{array}{l}\text { Consider verifiability and independent } \\
\text { review of the demonstration. }\end{array}$ & Sandia & Interest Group \\
\hline $\begin{array}{l}\text { Tribal Rights and Future Land Uses } \\
\text { - There is a perceived advantage on the } \\
\text { reservation to this technology as being a } \\
\text { natural process, which is protective of the } \\
\text { natural environment. }\end{array}$ & INEL & Tribes \\
\hline Regulatory Compliance & & \\
\hline $\begin{array}{l}\text { Regulatory permitting and reporting } \\
\text { requirements include NESHAPS and risk- } \\
\text { based reporting, especially of radioactive } \\
\text { co-contaminants. Evaluate the ability to } \\
\text { meet regulatory standards, ranges of } \\
\text { effectiveness, and interim versus final } \\
\text { results. Include the off-gas from process } \\
\text { intermediates (using human health-based } \\
\text { risk limits). }\end{array}$ & $\begin{array}{ll}- & \text { Los Alamos } \\
\text { - } & \text { Sandia }\end{array}$ & $\begin{array}{l}\text { Technology User } \\
\text { Interest Group } \\
\text { Regulator } \\
\text { Technology User }\end{array}$ \\
\hline $\begin{array}{l}\text { Assess optimum nitrate concentrations in } \\
\text { ground water and compliance with the } 10 \\
\text { ppm drinking water standard. Levels of } \\
\text { nutrient injection below drinking water } \\
\text { standards must be maintained to inspire } \\
\text { confidence in ground water regulators. }\end{array}$ & Sandia & Regulator \\
\hline
\end{tabular}




\begin{tabular}{|c|c|c|c|}
\hline & ISSUES BY CATEGORY & $\begin{array}{l}\text { SITES WHERE ISSUES } \\
\text { RAISED }\end{array}$ & $\begin{array}{l}\text { STAKEHOLDER } \\
\text { CATEGORIES }\end{array}$ \\
\hline - & $\begin{array}{l}\text { New Mexico will not permit the } \\
\text { subsurface injection of anything into } \\
\text { ground water or within } 50 \text { feet of ground } \\
\text { water. }\end{array}$ & Sandia & Technology User \\
\hline \multicolumn{4}{|c|}{ Other } \\
\hline - & This is an attractive technology. & NEL & Technology User \\
\hline - & $\begin{array}{l}\text { A treatability study of the use of } \\
\text { bioremediation in soils is being conducted } \\
\text { at Rocky Flats. }\end{array}$ & Rocky Flats & Regulator \\
\hline - & $\begin{array}{l}\text { Compare bioremediation to other } \\
\text { technologies. Comparison to pump and } \\
\text { treat may be biased; a more comparable } \\
\text { baseline technology may be in-well vapor } \\
\text { stripping. }\end{array}$ & Rocky Flats & Regulator \\
\hline - & $\begin{array}{l}\text { The statement in the profile that EPA's } \\
\text { strong endorsement adds credibility to } \\
\text { bioremediation may not be accurate; the } \\
\text { public is skeptical of EPA. }\end{array}$ & Rocky Flats & Regulator \\
\hline - & $\begin{array}{l}\text { The highest comfort level is with above- } \\
\text { ground technologies. }\end{array}$ & Rocky Flats & Technology User \\
\hline - & $\begin{array}{l}\text { Reduction of soil permeability is not } \\
\text { necessarily of added value in plutonium- } \\
\text { contaminated soils if the plutonium is } \\
\text { bound to the soil and non-mobile. }\end{array}$ & Rocky Flats & Public Official \\
\hline
\end{tabular}




\subsection{PASSIVE SOIL VAPOR EXTRACTION}

Passive soil vapor extraction is a seemingly "low-tech" approach to removing contaminants from soil in vapor form. As described in Section 3, it takes advantage of natural atmospheric pressure changes to remove VOCs, which are then handled at the surface. Stakeholders at all the sites raised a number of questions and issues related to its demonstration and potential deployment, providing extensive input to the technology test plan. Input from Hanford stakeholders is provided in detail in the two reports cited.earlier. Principal stakeholder concerns fell into the categories of practicality, works as intended, and public health and safety. Significant comments were also received in the categories of remaining contamination, cost, time, environmental impacts, public perception, and regulatory compliance.

The areas of emphasis were similar between Hanford stakeholders and those from other arid sites. In addition, however, the other arid sites provided augmenting or site-specific input critical to broad deployment. In analyzing the comments received in each issue or criterion category, the following similarities and differences are noted.

\section{$\underline{\text { Remaining Contamination }}$}

Hanford stakeholders requested clear demonstration of the level to which contaminants can be reduced using passive soil vapor extraction. They also questioned how investigators will know when the target levels have been reached. Stakeholders suggested that the passive system be coupled with active soil vapor extraction as well as tested on its own. A major issue was the ability to address co-contaminants, especially radioactive co-contaminants.

INEL regulators raised questions about the effects of temperature, asking for information on induced temperature gradients and potential resulting condensation of VOCs into NAPLs. The number of boreholes required to effect passive soil vapor extraction was of concern, especially as they may redistribute contamination. Other inputs from stakeholders at the other arid sites included a question about the time required to achieve cleanup, and whether residual contamination would always remain, thus affecting future land-use decisions.

\section{Process Waste}

The potential for numerous abandoned, grouted wells was seen as a concern in the long term by Hanford stakeholders. In addition, the management of GAC used for off-gas capture was of concern.

\section{Practicality}

As with other technologies, most comments fell into the category of practicality. Hanford stakeholders requested information on the technology's versatility -- whether it can treat cocontaminants, whether it can act as a containment technology, and whether it can function at a range of depths in various soil types and moisture levels. The demonstration must determine 
the following: the degree of pressure change needed for this approach to remediation to produce significant results, required well diameters, flow rates, the zone of influence of the wells, and the ranges of contaminants feasible for application. Use of passive soil vapor extraction in combination with other technologies (active extraction, bioremediation, etc.) should be explored, and the level of characterization needed to support the technology should be identified. The technology's applicability to different types of contaminant problems -e.g., providing containment at the edge of a plume -- should be investigated.

Stakeholders at the other arid sites echoed many of these ideas, adding more emphasis to concerns about monitoring and controlling the atmospheric flux from boreholes, capturing off gas, and ensuring effectiveness in varying site conditions. A New Mexico regulator raised a concern about site security, suggesting that vandalism may occur. High winds at Rocky Flats were also mentioned as a potential limitation.

\section{Works as Intended}

Comments in this category overlapped significantly with comments concerning practicality. Whether or not the technology will work at all, and effectively, was the primary concern of both Hanford stakeholders and those of the other arid sites. An INEL regulator suggested forcing air into formations as a mechanism to control plumes, or covering the surface to enhance extraction. At Los Alamos, a regulator questioned whether VOCs are diffusing out the sidewalls of mesas, and what effects fractured tuff would have on passive soil vapor extraction's performance. Rocky Flats regulators and users questioned whether low soil permeability would limit effectiveness and suggested that fracturing might improve recovery.

\section{$\underline{\text { Cost }}$}

Hanford stakeholders requested demonstration data on the costs of well installation, operation, maintenance, and monitoring over the potentially very long periods necessary to use the technology. Costs for enhancements must be included in the calculation, as well as for capturing off gases, GAC treatment, and for fencing, signage, and ecological monitoring. Cost/benefit ratios should be addressed in terms of incremental benefit. Stakeholders at other sites suggested comparing passive soil vapor extraction with a trench system or horizontal collector pipe, and evaluating cost per pound of contaminant removed.

Time

Hanford stakeholders believed that though the technology may be inexpensive and simple to operate, it may take too long to achieve cleanup. Its best use may be as a long-term maintenance technology. A significant issue is applicable cleanup standards and the ability of the demonstration to provide data on the time needed to meet different and potentially changing standards and to allow for a range of land uses. 
Stakeholders at the other arid sites shared that concern, also questioning the remediation method's ability to address ground-water contamination in a timely fashion, and noting that speed of cleanup is important to regulators. A Rocky Flats regulator pointed out that CERCLA requires five-year reviews of effectiveness and that passive soil vapor extraction may not yield sufficient results in that timeframe.

\section{Worker Safety}

Hanford stakeholders want information on the need for personnel protective equipment in the event of contacting pockets of highly concentrated VOCs during installation, operation, and maintenance. Data are needed for exposure rates at different distances from the wells, for a range of contaminants and concentrations. No specific comments on worker safety were received from the other arid sites.

\section{Public Health and Safety}

Stakeholders at Hanford and the other sites expressed significant concern about capturing volatilized VOCs released from wells. They believed strongly that such releases must be captured and treated, rather than being vented to the air. This was, in fact, the most emphasized issue related to passive soil vapor extraction. Regulators, technology users, public officials, and representatives of interest groups and tribes all stressed this as a critical requirement for the acceptance of the technology. Thus, the demonstration test plan data requirements included determining the types and levels of gas that could be produced, analyzing effective capture and treatment methods, and addressing this problem even beyond the requirements for direct air release permits.

\section{Environmental Impacts}

Hanford stakeholders raised issues about environmental impacts of passive soil vapor extraction, including effects of additional wells, climatic effects, and the potential need for a study of ecological effects. Other arid site stakeholders expressed concern about spreading contamination in unpredictable directions, creating contaminant pathways at depth, or affecting the subsurface through the influx of air at different temperatures. A Sandia technology user suggested evaluating odors from the system, which may be a problem in urban areas.

\section{Public Perception}

Hanford stakeholder input centered around the goals for cleanup, and the reasonableness of "pristine" as a cleanup goal. Other sites' stakeholders indicated that the technology's simplicity, apparent low cost, and "low-tech" nature may help with public acceptance, as may the fact that it is, at least in essence, a natural phenomenon. 


\section{Tribal Rights and Future Land Uses}

No specific comments were received in this category.

\section{$\underline{\text { Socio-Economic Interests }}$}

No specific comments were received in this category.

\section{Compatibility with Cleanup Milestones}

A Hanford stakeholder raised a question about the ability to use this technology to meet regulatory cleanup milestones, since its rate of contaminant removal will probably be slower than active systems. No specific comments were received in this category from the other arid sites.

\section{Regulatory Infrastructure}

Hanford stakeholders urged that the demonstration determine the appropriate standards against which the technology will be judged (e.g., MCLs, other). Stakeholders at the other arid sites suggested that regulatory approval may be unpredictable, given risk aversion and the time the technology requires to reach milestones. It was suggested that independent, third-party verifications of performance may help with regulatory acceptance.

\section{$\underline{\text { Regulatory Compliance }}$}

Hanford stakeholders raised issues about defining the regulatory goals and requirements applicable to use of passive soil vapor extraction. It is essential to analyze off gas in terms of its chemical and radioactive contaminants, and applicable air pollution requirements. Well completion requirements should also be considered. Stakeholders from other arid sites expressed similar concerns.

Table 5 on the following pages summarizes comments on passive soil vapor extraction (PSVE), organized by criterion category, from stakeholders at the other arid sites. 


\begin{tabular}{|c|c|c|c|}
\hline & ISSUES BY CATEGORY & $\begin{array}{l}\text { SITES WHERE ISSUES } \\
\text { RAISED } \\
\end{array}$ & $\begin{array}{c}\text { STAKEHOLDER } \\
\text { CATEGORIES } \\
\end{array}$ \\
\hline \multicolumn{4}{|c|}{ Remaining Contamination } \\
\hline & $\begin{array}{l}\text { Determine if PSVE will induce a } \\
\text { temperature gradient causing VOCs to } \\
\text { change from vapor phase to liquid } \\
\text { phase, thus condensing NAPLs in the } \\
\text { subsurface. }\end{array}$ & INEL & Regulator \\
\hline - & $\begin{array}{l}\text { Will PSVE require so many boreholes } \\
\text { that they will serve to redistribute } \\
\text { contamination? }\end{array}$ & INEL & Regulator \\
\hline - & $\begin{array}{l}\text { Define the effectiveness of the } \\
\text { technology with co-contaminants, } \\
\text { including radioactive co-contaminants, } \\
\text { and the potential effects on non-target } \\
\text { contaminants (e.g., co-precipitation, } \\
\text { co-vaporization, co-reformation and } \\
\text { release, and effects on animal or } \\
\text { human uptake). }\end{array}$ & $\begin{array}{l}\text { INEL } \\
\text { Rocky Flats } \\
\end{array}$ & $\begin{array}{ll}- & \text { Tribes } \\
- & \text { Interest Group }\end{array}$ \\
\hline • & $\begin{array}{l}\text { Release of contamination to the air is } \\
\text { unacceptable; contamination needs to } \\
\text { be totally destroyed. It is better to } \\
\text { keep it in the vadose zone and monitor } \\
\text { it than to release it to the air. }\end{array}$ & - Los Alamos & Tribes \\
\hline • & $\begin{array}{l}\text { Assess the ability of the technology to } \\
\text { stop contaminant migration so that } \\
\text { there is not seepage into } \\
\text { uncontaminated areas. }\end{array}$ & Rocky Flats & Interest Group \\
\hline • & $\begin{array}{l}\text { Define estimated results in advance of } \\
\text { demonstration. }\end{array}$ & Rocky Flats & Interest Group \\
\hline${ }^{\circ}$ & $\begin{array}{l}\text { Assess time and efficiency compared } \\
\text { with active systems, and evaluate } \\
\text { whether gains outweigh loss of } \\
\text { efficiency. }\end{array}$ & Rocky Flats & $\begin{array}{l}\text { Regulator } \\
\text { Public Official }\end{array}$ \\
\hline • & $\begin{array}{l}\text { Consider natural biodegradation as a } \\
\text { contributor to decreases in } \\
\text { concentrations of VOCs in soils. }\end{array}$ & Rocky Flats & Regulator \\
\hline
\end{tabular}




\begin{tabular}{|c|c|c|}
\hline ISSUES BY CATEGORY & $\begin{array}{l}\text { SITES WHERE ISSUES } \\
\text { RAISED }\end{array}$ & $\begin{array}{l}\text { STAKEHOLDER } \\
\text { CATEGORIES }\end{array}$ \\
\hline $\begin{array}{l}\text { Assess whether there will be residual } \\
\text { contamination. The levels of } \\
\text { acceptable residuals depend on future } \\
\text { land use. }\end{array}$ & - $\quad$ Rocky Flats & Technology User \\
\hline $\begin{array}{l}\text { Consider injecting air into the } \\
\text { subsurface to increase the flow of the } \\
\text { contaminated air stream. }\end{array}$ & - $\quad$ Rocky Flats & Technology User \\
\hline $\begin{array}{l}\text { Evaluate whether the technology will } \\
\text { change the characteristics of the } \\
\text { contaminant. }\end{array}$ & Rocky Flats & Technology User \\
\hline \multicolumn{3}{|l|}{ Process Waste } \\
\hline $\begin{array}{l}\text { Evaluate the effects of tritium } \\
\text { exhausting in vapor form. }\end{array}$ & Los Alamos & Technology User \\
\hline $\begin{array}{l}\text { - Consider a 1-pound/hour limit for } \\
\text { VOCs in off gas in Clean Air Act non- } \\
\text { attainment areas. }\end{array}$ & Sandia & Regulator \\
\hline
\end{tabular}




\begin{tabular}{|c|c|c|}
\hline ISSUES BY CATEGORY & $\begin{array}{c}\text { SITES WHERE ISSUES } \\
\text { RAISED } \\
\end{array}$ & $\begin{array}{l}\text { STAKEHOLDER } \\
\text { CATEGORIES }\end{array}$ \\
\hline \multicolumn{3}{|l|}{ Practicality } \\
\hline $\begin{array}{l}\text { This is an appropriate technology for } \\
\text { areas with dilute concentrations of } \\
\text { VOCs in the vadose zone. }\end{array}$ & INEL & Interest Group \\
\hline $\begin{array}{l}\text { Assess the ability to control and } \\
\text { predict performance of a passive } \\
\text { system, and define the time frame over } \\
\text { which confident predictions are } \\
\text { possible. }\end{array}$ & $\begin{array}{ll}- & \text { INEL } \\
\text { - } & \text { Rocky Flats }\end{array}$ & $\begin{array}{ll}- & \text { Regulator } \\
& \text { Public Official }\end{array}$ \\
\hline $\begin{array}{l}\text { Demonstrate what is gained by not } \\
\text { making the system active. }\end{array}$ & Rocky Flats & Regulator \\
\hline $\begin{array}{l}\text { Assess the ability of PSVE to work in } \\
\text { combination with other technologies. } \\
\text { Consider using perimeter PSVE wells } \\
\text { with active soil vapor extraction } \\
\text { (ASVE) at the center, or using the } \\
\text { ASVE in a pulsed mode to accomplish } \\
\text { additional extraction. }\end{array}$ & $\begin{array}{ll}- & \text { INEL } \\
\text { - } & \text { Rocky Flats }\end{array}$ & $\begin{array}{ll}- & \text { Interest Group } \\
- & \text { Technology User }\end{array}$ \\
\hline $\begin{array}{l}\text { Define optimum borehole sizes in } \\
\text { varying strata, the number of borings } \\
\text { needed, the details of well construction } \\
\text { needed, and the desired zone of } \\
\text { influence. }\end{array}$ & $\begin{array}{ll}\text { - } & \text { INEL } \\
\text { - } & \text { Los Alamos }\end{array}$ & $\begin{array}{l}\text { Regulator } \\
\text { Technology User } \\
\text { Technology User }\end{array}$ \\
\hline $\begin{array}{l}\text { Evaluate the ability to use with } \\
\text { existing wells and define the } \\
\text { requirements for those wells. }\end{array}$ & $\begin{array}{ll}\text { - } & \text { INEL } \\
& \text { Sandia }\end{array}$ & $\begin{array}{ll}\text { - } & \text { Technology User } \\
\text { - Technology User }\end{array}$ \\
\hline $\begin{array}{l}\text { Define the range of site conditions in } \\
\text { which the technology will be effective, } \\
\text { the effect of these conditions on flux } \\
\text { rates, and the upper limit for effective } \\
\text { operation of the process. }\end{array}$ & $\begin{array}{ll}- & \text { INEL } \\
\text { - } & \text { Los Alamos } \\
\text { Rocky Flats } \\
\\
\text { - Sandia }\end{array}$ & $\begin{array}{ll}\text { - } & \text { Regulator } \\
\text { - } & \text { Technology User } \\
\text { Technology User } \\
\text { - } \quad \text { Tegulator } \\
\text { Technology User }\end{array}$ \\
\hline
\end{tabular}




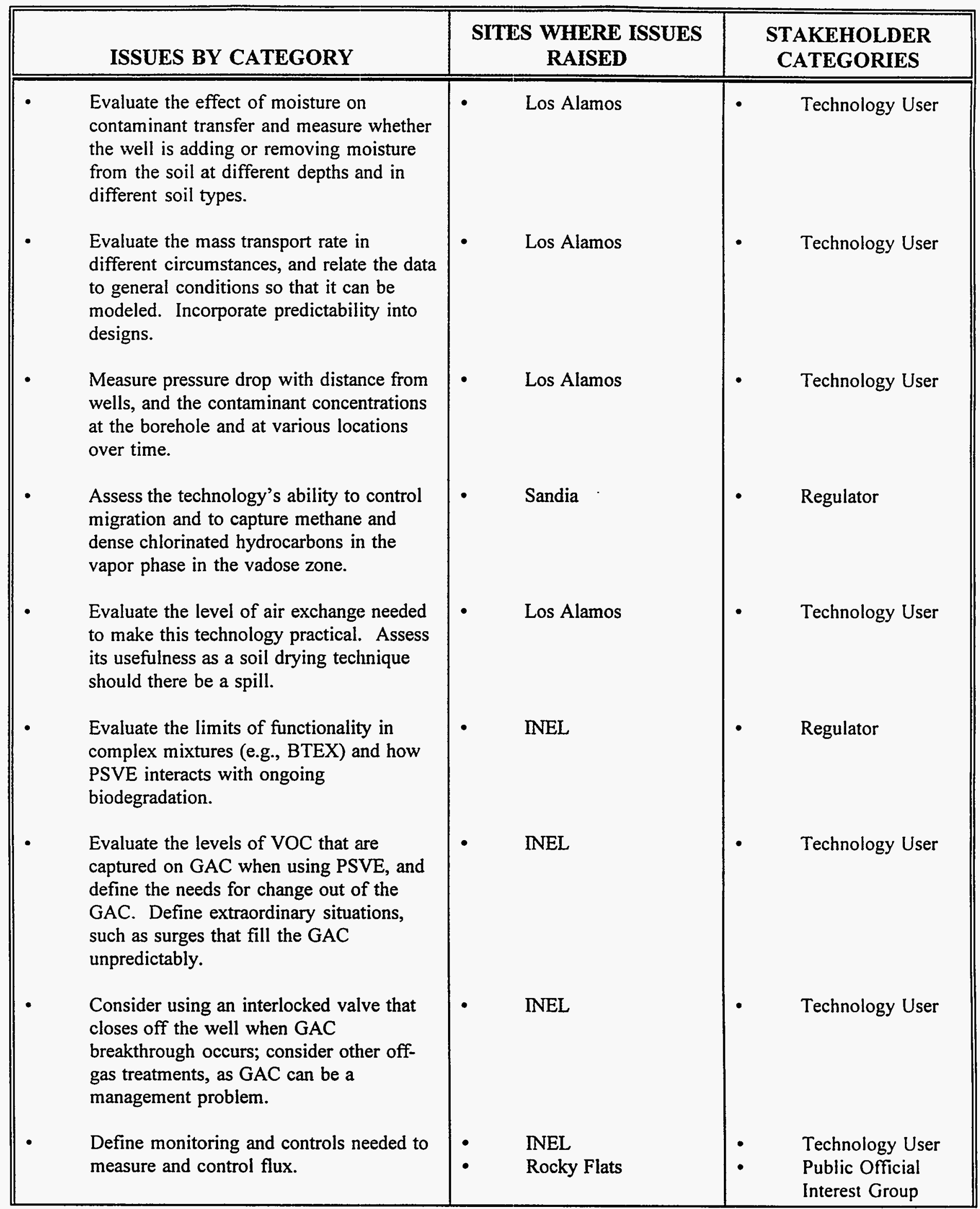




\begin{tabular}{|c|c|c|c|}
\hline & ISSUES BY CATEGORY & $\begin{array}{l}\text { SITES WHERE ISSUES } \\
\text { RAISED }\end{array}$ & $\begin{array}{l}\text { STAKEHOLDER } \\
\text { CATEGORIES }\end{array}$ \\
\hline - & $\begin{array}{l}\text { Evaluate the suitability of PSVE for early } \\
\text { stages of cleanup. }\end{array}$ & - INEL & Technology User \\
\hline - & $\begin{array}{l}\text { Assess its effectiveness in late-stage } \\
\text { remediation where chlorinated solvents are } \\
\text { contained in tight silts and clays that don't } \\
\text { respond well to ASVE. }\end{array}$ & Sandia & Regulator \\
\hline - & $\begin{array}{l}\text { PSVE will be a secondary treatment } \\
\text { method; it may not be an effective } \\
\text { primary technology for source removal. It } \\
\text { will never meet ARARs. }\end{array}$ & $\begin{array}{l}\text { - } \quad \text { NEL } \\
\quad \text { Los Alamos }\end{array}$ & $\begin{array}{l}\text { Technology User } \\
\text { Regulator }\end{array}$ \\
\hline - & $\begin{array}{l}\text { Define the meteorological conditions, } \\
\text { including wind, temperature, and high- } \\
\text { pressure systems, under which the } \\
\text { technology will work most effectively, } \\
\text { and the role of wind in affecting natural } \\
\text { soil vapor extraction. }\end{array}$ & $\begin{array}{ll}- & \text { INEL } \\
- & \text { Los Alamos } \\
& \text { Rocky Flats }\end{array}$ & $\begin{array}{l}\text { Technology User } \\
\text { Regulator } \\
\text { Interest Group } \\
\text { Regulator }\end{array}$ \\
\hline - & $\begin{array}{l}\text { Define if housing the extraction area in a } \\
\text { building or tent would be needed to } \\
\text { protect the equipment from snow or } \\
\text { extremes in temperature. Determine how } \\
\text { maintenance would be done in these } \\
\text { circumstances. }\end{array}$ & INEL & Technology User \\
\hline - & $\begin{array}{l}\text { Watch for removal correlations with } \\
\text { phases of the moon and tidal effects. }\end{array}$ & Los Alamos & Technology User \\
\hline - & Evaluate security and maintenance needs. & Sandia & $\begin{array}{l}\text { Regulator } \\
\text { Technology User }\end{array}$ \\
\hline - & $\begin{array}{l}\text { Define the need for any in-situ equipment } \\
\text { to operate the technology and its function. }\end{array}$ & Rocky Flats & Interest Group \\
\hline - & $\begin{array}{l}\text { Evaluate the effectiveness of the } \\
\text { technology. It could be useful for landfill } \\
\text { gases. }\end{array}$ & Sandia & Public Official \\
\hline - & $\begin{array}{l}\text { This is an attractive technology because it } \\
\text { is inexpensive and no power is needed. }\end{array}$ & Sandia & Technology User \\
\hline - & $\begin{array}{l}\text { Evaluate the ability to obtain the } \\
\text { technology from multiple vendors; there } \\
\text { appear to be multiple suppliers. }\end{array}$ & Sandia & Technology User \\
\hline
\end{tabular}




\begin{tabular}{|c|c|c|c|}
\hline & ISSUES BY CATEGORY & $\begin{array}{l}\text { SITES WHERE ISSUES } \\
\text { RAISED }\end{array}$ & $\begin{array}{l}\text { STAKEHOLDER } \\
\text { CATEGORIES }\end{array}$ \\
\hline \multicolumn{4}{|c|}{ Works as Intended } \\
\hline - & $\begin{array}{l}\text { Consider demonstrating PSVE in an area } \\
\text { where ASVE has been carried out so that } \\
\text { the zone is at a realistic place on the } \\
\text { contaminant removal curve. Try two } \\
\text { demonstrations, one after ASVE and one } \\
\text { before, but only when the risk to other } \\
\text { environmental media is low. }\end{array}$ & NNEL & Regulator \\
\hline - & $\begin{array}{l}\text { Consider forcing air into the formation as } \\
\text { a mechanism to control plumes, and using } \\
\text { a plastic surface cover over certain areas } \\
\text { to enhance and direct flow. }\end{array}$ & INEL & Regulator \\
\hline - & $\begin{array}{l}\text { Determine whether VOCs diffuse out of } \\
\text { mesa sidewalls. }\end{array}$ & Los Alamos & Regulator \\
\hline - & $\begin{array}{l}\text { Assess the effects of subsurface fracturing } \\
\text { and permeability on PSVE performance. }\end{array}$ & $\begin{array}{ll}- & \text { Los Alamos } \\
- & \text { Rocky Flats }\end{array}$ & $\begin{array}{ll}- & \text { Regulator } \\
- & \text { Regulator }\end{array}$ \\
\hline - & $\begin{array}{l}\text { Evaluate previous uses and successes of } \\
\text { the technology. It has been used at gas } \\
\text { station sites. }\end{array}$ & Los Alamos & Regulator \\
\hline - & $\begin{array}{l}\text { Define the radius of influence of the } \\
\text { technology, the number of wells needed, } \\
\text { the distance between them, the } \\
\text { configuration of borehole arrays, and the } \\
\text { time required for the technology to } \\
\text { function effectively. Assess the ability of } \\
\text { the technology to handle large plumes. }\end{array}$ & $\begin{array}{l}\text { - } \quad \text { Los Alamos } \\
\text { - } \quad \text { Sandia }\end{array}$ & $\begin{array}{l}\text { Interest Group } \\
\text { Technology User } \\
\text { Interest Group } \\
\text { Technology User }\end{array}$ \\
\hline - & Calculate mass removal over time. & Sandia & Technology User \\
\hline • & $\begin{array}{l}\text { Define how gradients and pressure } \\
\text { fluctuations will be used to achieve } \\
\text { cleanup and how they will be controlled. }\end{array}$ & Rocky Flats & Interest Group \\
\hline - & $\begin{array}{l}\text { Evaluate the volume of VOCs released } \\
\text { from the soil by pressure changes as } \\
\text { compared to just moving entrained VOCs. } \\
\text { up and down a little in the soil. }\end{array}$ & Los Alamos & Technology User \\
\hline - & $\begin{array}{l}\text { It is important to understand the limiting } \\
\text { factors for the technology and the bases } \\
\text { for those limitations. }\end{array}$ & Los Alamos & Technology User \\
\hline
\end{tabular}




\begin{tabular}{|c|c|c|c|}
\hline & ISSUES BY CATEGORY & $\begin{array}{c}\text { SITES WHERE ISSUES } \\
\text { RAISED }\end{array}$ & $\begin{array}{l}\text { STAKEHOLDER } \\
\text { CATEGORIES }\end{array}$ \\
\hline - & $\begin{array}{l}\text { Use peizometers at radial distances to } \\
\text { determine the zone of influence of the } \\
\text { wells. Expect nonsymmetric zones of } \\
\text { influence based on discontinuities in the } \\
\text { subsurface. }\end{array}$ & Los Alamos & Technology User \\
\hline - & $\begin{array}{l}\text { Demonstrate that heavy vapors will } \\
\text { actually move to the surface from } 100 \text { feet } \\
\text { below grade. }\end{array}$ & - Sandia & Regulator \\
\hline - & $\begin{array}{l}\text { To measure the success of PSVE, assess } \\
\text { how much natural biodegradation of } \\
\text { VOCs is occurring and has occurred. }\end{array}$ & Rocky Flats & Regulator \\
\hline - & $\begin{array}{l}\text { Define the barometric changes needed to } \\
\text { bring contaminants to the surface. }\end{array}$ & Rocky Flats & Regulator \\
\hline - & $\begin{array}{l}\text { Evaluate requirements for attaching } \\
\text { treatment systems while still retaining } \\
\text { pressure differentials. }\end{array}$ & $\begin{array}{l}\text { - } \quad \text { Rocky Flats } \\
\text { Sandia }\end{array}$ & $\begin{array}{ll}- & \text { Regulator } \\
\text { - } & \text { Technology User }\end{array}$ \\
\hline - & $\begin{array}{l}\text { Define flux rates and the mobility of } \\
\text { contamination. Consider the effects if } \\
\text { migration moves contamination faster than } \\
\text { PSVE can remove it. Use ASVE in these } \\
\text { situations. }\end{array}$ & Sandia & Interest Group \\
\hline - & $\begin{array}{l}\text { Evaluate taking advantage of subsurface } \\
\text { stratigraphy to use natural flux most } \\
\text { effectively. }\end{array}$ & Sandia & Technology User \\
\hline \multicolumn{4}{|c|}{ Cost } \\
\hline - & $\begin{array}{l}\text { Evaluate the system costs and cost per } \\
\text { pound of contaminant removed. Low cost } \\
\text { is an advantage. }\end{array}$ & $\begin{array}{ll}- & \text { INEL } \\
- & \text { Sandia }\end{array}$ & $\begin{array}{l}\text { Technology User } \\
\text { Interest Group }\end{array}$ \\
\hline - & $\begin{array}{l}\text { Define the cost effectiveness of the } \\
\text { technology, and compare cost } \\
\text { effectiveness with a trench system or } \\
\text { horizontal collector pipes. }\end{array}$ & $\begin{array}{ll}\text { - } & \text { Los Alamos } \\
\text { - } & \text { Sandia }\end{array}$ & $\begin{array}{l}\text { Technology User } \\
\text { Regulator }\end{array}$ \\
\hline$\cdot$ & $\begin{array}{l}\text { Evaluate startup costs, including the cost } \\
\text { of drilling wells. Startup costs for the } \\
\text { technology appear to be low. }\end{array}$ & Sandia & Technology User \\
\hline
\end{tabular}




\begin{tabular}{|c|c|c|c|}
\hline & ISSUES BY CATEGORY & $\begin{array}{l}\text { SITIES WHERE I } \\
\text { RAISED }\end{array}$ & $\begin{array}{l}\text { STAKEHOLDER } \\
\text { CATEGORIES }\end{array}$ \\
\hline \multicolumn{4}{|c|}{ Time } \\
\hline - & $\begin{array}{l}\text { Address both the effectiveness and the } \\
\text { time required for cleanup to specified } \\
\text { levels. Speed is important to regulators. }\end{array}$ & $\begin{array}{ll}- & \text { INEL } \\
& \text { Sandia }\end{array}$ & $\begin{array}{l}\text { Interest Group } \\
\text { Interest Group } \\
\text { Regulator } \\
\text { Technology User }\end{array}$ \\
\hline - & $\begin{array}{l}\text { Evaluate the extremely long cleanup time } \\
\text { needed to reach regulatory standards and } \\
\text { to address ground water contamination. } \\
\text { There is no mechanism for faster } \\
\text { operation. Will cleanup deadlines prevent } \\
\text { this technology from being used? }\end{array}$ & $\begin{array}{ll}- & \text { INEL } \\
- & \text { Los Alamos } \\
& \text { Rocky Flats }\end{array}$ & $\begin{array}{ll}- & \text { Technology User } \\
\text { - } & \text { Public Official } \\
\text { Technology User }\end{array}$ \\
\hline - & $\begin{array}{l}\text { Evaluate the ability to couple PSVE with } \\
\text { ASVE to maximize removal as quickly as } \\
\text { possible. }\end{array}$ & Sandia & Interest Group \\
\hline \multicolumn{4}{|c|}{ Public Health and Safety } \\
\hline - & $\begin{array}{l}\text { Subsurface VOCs released at the surface } \\
\text { through PSVE must be captured and } \\
\text { treated. Evaluate off-gas production and } \\
\text { the portion captured. Define whether the } \\
\text { off gas is acceptable to diffuse. }\end{array}$ & $\begin{array}{ll}\text { - } & \text { INEL } \\
\text { - } & \text { Los Alamos } \\
\text { - } & \begin{array}{l}\text { Rocky Flats } \\
\text { - }\end{array} \\
\text { Sandia }\end{array}$ & $\begin{array}{ll}\text { - } & \text { Interest Group } \\
\text { - } & \text { Technology User } \\
\text { Interest Group } \\
\text { Public Official } \\
\text { Regulator } \\
\text { - } \quad \text { Technology User } \\
\text { - } \quad \text { Interest Group } \\
\text { Regulator } \\
\text { Technology User }\end{array}$ \\
\hline - & $\begin{array}{l}\text { Evaluate emissions from the technology, } \\
\text { plans for recovering vapor or venting it to } \\
\text { the atmosphere, and effects of this venting } \\
\text { on human health. }\end{array}$ & $\begin{array}{ll}\text { - } & \text { Rocky Flats } \\
\text { - } & \text { Sandia }\end{array}$ & $\begin{array}{l}\text { Interest Group } \\
\text { Interest Group }\end{array}$ \\
\hline - & $\begin{array}{l}\text { Evaluate the ability to control well venting } \\
\text { when wells are no longer monitored. }\end{array}$ & Sandia & Regulator \\
\hline - & $\begin{array}{l}\text { Consider PSVE's potential to encourage } \\
\text { migration of dissolved contaminants } \\
\text { toward the water table. }\end{array}$ & Sandia & Regulator \\
\hline - & $\begin{array}{l}\text { Assess whether the pressure dynamics } \\
\text { induced by PSVE will push contaminants } \\
\text { in unanticipated directions. }\end{array}$ & Rocky Flats & $\begin{array}{l}\text { Interest Group } \\
\text { Technology User }\end{array}$ \\
\hline - & $\begin{array}{l}\text { Evaluate the potential for VOC } \\
\text { flammability in an open system and the } \\
\text { potential for explosion. }\end{array}$ & Sandia & $\begin{array}{l}\text { Regulator } \\
\text { Technology User }\end{array}$ \\
\hline
\end{tabular}




\begin{tabular}{|c|c|c|}
\hline ISSUES BY CATEGORY & $\begin{array}{l}\text { SITES WHERE ISSUES } \\
\text { RAISED }\end{array}$ & $\begin{array}{l}\text { STAKEHOLDER } \\
\text { CATEGORIES }\end{array}$ \\
\hline \multicolumn{3}{|l|}{ Environmental Impacts } \\
\hline $\begin{array}{l}\text { Assess the environmental impacts of the } \\
\text { technology. }\end{array}$ & INEL & Interest Group \\
\hline $\begin{array}{l}\text { Evaluate the potential for penetrating an } \\
\text { impermeable layer at depth and creating a } \\
\text { contaminant pathway, particularly into the } \\
\text { Snake River aquifer. }\end{array}$ & INEL & Interest Group \\
\hline $\begin{array}{l}\text { Pressure differentials could spread } \\
\text { contamination in unpredictable directions. } \\
\text { PSVE is a "nice but crude idea." }\end{array}$ & Rocky Flats & Interest Group \\
\hline $\begin{array}{l}\text { Assess the use of solar energy with PSVE. } \\
\text { Use ASVE when contamination threatens } \\
\text { imminent damage. }\end{array}$ & Sandia & Interest Group \\
\hline $\begin{array}{l}\text { Assess subsurface impacts from the influx } \\
\text { of air, temperature changes, etc., and } \\
\text { evaluate the effect on natural degradation, } \\
\text { and stimulation of microbes. }\end{array}$ & Sandia & Technology User \\
\hline $\begin{array}{l}\text { Investigate odors from the system; this } \\
\text { could be a problem in urban areas. }\end{array}$ & Sandia & Technology User \\
\hline \multicolumn{3}{|l|}{ Public Perception } \\
\hline $\begin{array}{l}\text { The simplicity and low cost of the } \\
\text { technology are positive attributes. } \\
\text { Taxpayers will like its low cost, but will } \\
\text { the public be patient with the slow rate? }\end{array}$ & INEL & Technology User \\
\hline $\begin{array}{l}\text { A low-technology solution will likely be } \\
\text { acceptable to the public since it is } \\
\text { understandable. }\end{array}$ & $\begin{array}{ll}- & \text { Los Alamos } \\
\text { - } & \text { Sandia }\end{array}$ & $\begin{array}{l}\text { Regulator } \\
\text { Interest Group }\end{array}$ \\
\hline $\begin{array}{l}\text { This technology is less of a concern } \\
\text { because it is a natural phenomenon. }\end{array}$ & Sandia & Interest Group \\
\hline
\end{tabular}




\begin{tabular}{|c|c|c|c|}
\hline & ISSUES BY CATEGORY & $\begin{array}{c}\text { SITES WHERE ISSUES } \\
\text { RAISED }\end{array}$ & $\begin{array}{l}\text { STAKEHOLDER } \\
\text { CATEGORIES }\end{array}$ \\
\hline \multicolumn{4}{|c|}{ Regulatory Infrastructure and Track Record } \\
\hline • & $\begin{array}{l}\text { Independent, third-party verification of } \\
\text { success and reference to historical use of } \\
\text { the technology are important, especially to } \\
\text { federal and state regulators. }\end{array}$ & Los Alamos & Regulator \\
\hline - & $\begin{array}{l}\text { The technology is unpredictable in terms } \\
\text { of regulator approval due to the time and } \\
\text { rate of mass removal, and the uncertainty } \\
\text { of the risks. }\end{array}$ & Sandia & Regulator \\
\hline - & $\begin{array}{l}\text { Evaluate regulators' familiarity with the } \\
\text { system. There may be problems in } \\
\text { deployment decisions for regulators } \\
\text { involved with hazardous wastes; however, } \\
\text { PSVE is currently used by EPA for radon } \\
\text { control. }\end{array}$ & Sandia & Technology User \\
\hline \multicolumn{4}{|c|}{ Regulatory Compliance } \\
\hline • & $\begin{array}{l}\text { Assess off-gas concentrations produced by } \\
\text { PSVE and the technology's ability to meet } \\
\text { state air quality regulations and Clean Air } \\
\text { Act requirements. A permit will be } \\
\text { required in New Mexico; the regulatory } \\
\text { limit for hazardous constituents is zero, so } \\
\text { off-gas control is essential. }\end{array}$ & $\begin{array}{ll}\text { - } & \text { Los Alamos } \\
\text { Sandia }\end{array}$ & $\begin{array}{l}\text { Regulator } \\
\text { Technology User } \\
\text { Technology User }\end{array}$ \\
\hline - & $\begin{array}{l}\text { Evaluate technology's ability to produce } \\
\text { sufficient results for CERCLA five-year } \\
\text { review. }\end{array}$ & Rocky Flats & Regulator \\
\hline - & $\begin{array}{l}\text { There is a need for more information on } \\
\text { use in permeable zones to convince } \\
\text { regulators of the speed of cleanup. }\end{array}$ & Sandia & Technology User \\
\hline - & $\begin{array}{l}\text { Regulators may be satisfied with direct } \\
\text { venting, since it is acceptable to wind row } \\
\text { UST contaminated soil. }\end{array}$ & Sandia & Technology User \\
\hline \multicolumn{4}{|c|}{ Other } \\
\hline • & This is an attractive technology. & INEL & Technology User \\
\hline • & $\begin{array}{l}\text { Understanding this phenomenon may give } \\
\text { a- more realistic view of what subsurface } \\
\text { and contaminant conditions really exist. }\end{array}$ & - $\quad$ Rocky Flats & Regulator \\
\hline
\end{tabular}




\subsection{TUNABLE HYBRID PLASMA TREATMENT}

Tunable hybrid plasma treatment of VOC-contaminated air flows is a relatively complex and "high-tech" technology. Stakeholders at all the sites raised a large number of questions and issues about its demonstration and potential deployment, resulting in significant input to the technology test plan. Input from Hanford stakeholders is provided in detail in the two reports cited earlier. Principal stakeholder concerns about tunable hybrid plasma fell into the categories of process waste, practicality, whether the technology will function as intended, and cost. There were also concerns about remaining contamination, worker safety, public health and safety, and public perception.

Hanford stakeholders and those from the other arid sites shared similar perspectives. In addition, however, the other arid sites provided many insights and issues to augment those of the Hanford stakeholders. In analyzing the comments received in each issue or criterion category, the following similarities and differences become apparent.

\section{Remaining Contamination}

Hanford stakeholders stressed the need for the technology to handle co-contaminants -- metals, radionuclides, other organic compounds, and mixtures of VOCs. The limitations of the elements of the technology system (e.g., primary unit, dryer, scrubber) in light of treating of co-contaminants was raised as a demonstration data requirement. INEL technology users and Sandia interest groups also raised the issue of knowing the level of contaminant destruction, suggesting that 99.9999 percent destruction efficiency ("six nines") should be the goal, and pointing out the possibility of using multiple passes through the technology to achieve greater destruction.

\section{Process Waste}

Commenters at all the sites, including Hanford, focused on the salt cake or brine produced as a process waste. In general, the fact that "only salt" was produced by the technology was seen as an advantage. However, numerous questions were raised about optimal management of that salt. Suggested data requirements for the demonstration included evaluating the characteristics, volumes, and treatment and disposal options for the resulting salt, as well as markets for recycling or reusing the salt. Technology users and regulators added concerns about co-contaminants and by-products, questioning whether co-contaminants would end up in the salt cake, whether products of incomplete destruction (PICs) would remain, whether carbon tetrachloride would be sorbed in the drier unit or hypochlorite formed in the scrubber.

Transportation of the salt was raised as a concern at INEL, especially as related to crossing tribal lands. Los Alamos and Sandia regulators raised the questions of ozone production. probably due to the concern in New Mexico about air pollutants. Interest groups and regulators were particularly interested in the issue of contamination left in the process waste. A public official in the Rocky Flats area expressed concern about whether the residual salts 
can be safely disposed in local sanitary waste landfills, and what kinds of volumes would be involved.

\section{Practicality}

The largest number of comments about the practicality of this technology were received from technology users at Hanford. Hanford interest group representatives and regulators also raised a large number of issues related to how well the technology would perform. A basic request was to implement the demonstration to define how the technology will perform -- quantifying containment volume, mass, and concentration limits and field conditions (temperatures, humidity) for the technology. The full range (low to high) of its operational ability is of interest. Many stakeholders questioned how the technology would handle radioactive cocontaminants. The presence of acids in the air mix, and their effects on the equipment, were referenced. Many Hanford stakeholders questioned the versatility of the technology, asking if it can be used in combination with other technologies and in a range of ground water and soil cleanup situations. Stakeholders requested an analysis of possible failures (explosion, scrubber failure).

Reliability and compatibility were issues raised by INEL interest groups. An INEL regulator pointed out that comparison with granular activated carbon (GAC) is not appropriate at INEL, where they use a catalytic oxidation unit run with bottled propane as their baseline. INEL's current vapor vacuum extraction system functions at between 200-500 cubic feet per minute (cfm). Users recommended that the demonstration address whether tunable hybrid plasma will function effectively at those rates. New Mexico stakeholders also questioned the effective range, as New Mexico's air flow rates are also quite low. Another INEL user suggested a concern over gas leaks, and acid off gas and scaling in the scrubber.

A Los Alamos stakeholder raised a concern about providing power to remote locations. Los Alamos technology users, as users at all the sites, questioned the technology's operating and maintenance needs, including scrubber clogging and dryer fouling. A Sandia regulator brought up the issue of worker skills and training needed to operate the technology, and its ability to treat mixed waste streams.

Rocky Flats regulators questioned tunable hybrid plasma's ability to destroy pesticides, in particular organo-phosphates. Sandia interest groups stressed the need for portability and durability in severe weather. Sandia technology users stressed reliability and security requirements, as well as the effects of the trailer size.

\section{Works as Intended}

Evaluation of whether tunable hybrid plasma works as intended tended to overlap to some degree with the criterion of practicality. Hanford regulators and technology users requested demonstration data on the operating parameters and limitations of the technology, including 
air moisture, particulate level, hydrogen limitations, temperature limits, co-contaminant levels. mass loading, flow rate, and other factors in comparison with other treatment technologies.

Rocky Flats interest group representatives wanted information on destruction efficiencies, including the ability to destroy trichloroethane (TCE) and its break-down products, and the effect on destruction efficiency when the technology is tuned. A Rocky Flats regulator cited the ability to destroy contamination on site as a benefit of the technology, rather than transporting the contaminants to another location for treatment and disposal. Another request of a Rocky Flats regulator is to assess the technology's ability to treat contaminant concentrations below $10 \mathrm{ppm}$.

Sandia technology users added a question about exhausting heat from the system, and the potential for capturing and using some process heat. Specifically, Sandia technology users want an evaluation of the presence of metals and radionuclides in the air flow and their effects on the unit, and whether there will be pass-through residuals. A Sandia technology user cautioned that the evaluation should examine the entire treatment train in relation to performance, costs, risk, worker safety, and other factors.

\section{$\underline{\text { Cost }}$}

As with all the technologies, cost is important for all types of stakeholders at all the arid sites. Hanford stakeholders want to see total life-cycle costs for tunable hybrid plasma, including the cost of power, off-gas treatment, waste management, labor, and operation and maintenance, as well as capital and scale-up costs. Direct comparison with competing technologies is important; stakeholders mentioned other energy-addition technologies such as lasers, ZAPIT, ultraviolet light treatment, and other reduction and oxidation (REDOX) technologies, as well as GAC. A Hanford technology user requested information on the cost impacts of fluctuating flow rates and other operating parameters. Another technology user asked about the purity of the power source required for the technology.

Stakeholders at the other arid sites offered several additional perspectives. Interest group representatives, regulators, and technology users perceived the technology's cost as high for all its components, and questioned the costs estimated to date. Rocky Flats stakeholders added a question about cost per unit removed for low concentration gas streams. A Rocky Flats technology user wondered about operating and maintenance costs, given the low flow rates and long timeframes associated with soil vapor extraction systems in place at Rocky Flats. A Sandia interest group representative felt that, given the tradeoffs between capital and labor costs, technologies that provide jobs are preferable to expensive capital-cost technologies. Another Sandia stakeholder, a technology user, suggested that costs per unit may be significantly affected by operating costs, with such problems as poor maintenance, vandalism, transportation damage, lost-time shutdowns, and power costs. 
Time

The time required to bring the technology to bear, or to complete its mission, was not raised as a specific issue at any of the sites. Only one comment, from an INEL interest group representative, was received on this criterion; it involved gathering demonstration data regarding rate of technology performance, expressed in understandable comparative units.

\section{Worker Safety}

Hanford stakeholders made several key points about worker safety that were echoed by stakeholders at other sites. Both technology users and interest group representatives at Hanford specified that the demonstrations should include worst-case failure scenarios, and that failure controls and prevention methods be developed. Specific interest group questions included containment of hydrochloric acid, effects of shielding failure, and possible hazards of changing the scrubber solutions. Regulators requested information on contaminant detection and shut-down interlock systems, electromagnetic releases, the production of phosgene and other by-products, radiation releases, and electromagnetic field (EMF) effects.

INEL interest group representatives raised several specific concerns: confirming the technology's compliance with OSHA requirements, defining the number of people needed to operate it safely, and evaluating risk to operators. One INEL technology user indicated that no one will allow the technology to operate unattended. Los Alamos and Sandia regulators and interest groups shared concerns about radioactive emissions, "stray electrons," and mechanisms to protect people and equipment. A Sandia technology user questioned the skill and training needed, both for startup and ongoing maintenance.

\section{Public Health and Safety}

Hanford stakeholders focused on defining, monitoring, and controlling off-gas and stack exhaust. The presence of co-contaminants and by-products, and the ability of the technology to process them, are of major interest. Failure control and reporting is important, and there is concern about the potential for explosion. A Hanford tribal representative asked if the technology could be used for regenerating GAC.

The emphasis was the same at the other sites. Especially in New Mexico, air emissions or production of problematic by-products are of serious concern. Full characterization of off gases will be required. A Rocky Flats interest group questioned whether it is possible to develop a "feedstock" from the source contaminant, and wants to learn whether dioxins or furans may be formed by the process. One Rocky Flats regulator said that tunable hybrid plasma has been used in the past and would be acceptable with standard safeguards. A Sandia technology user wanted to see information on products of incomplete combustion, especially with fuels as co-contaminants. 


\section{Environmental Impacts}

Issues raised about the environmental impacts of tunable hybrid plasma centered around energy requirements. All categories of stakeholders, at all sites, wanted to see information on total power requirements, types of power needed, and costs of power. Two other impacts were discussed as well. Aesthetic impacts of the technology, and of needed power lines, were an issue with a public official at Los Alamos and an interest group representative at Sandia. The public official also pointed out that it is difficult to establish new power sources in New Mexico. Noise was also an issue raised by a Sandia technology user, as well as exhaust emissions if an on-site generator is needed for the power source.

\section{$\underline{\text { Public Perception }}$}

Hanford interest group representatives raised concerns about the comparability of tunable hybrid plasma with incineration. They requested a clear comparison of the technology with incineration and other destruction technologies, and clarification of whether it is more controllable. Chemical constituents in the off gas must be fully understood. Another broadlybased concern is the ability to easily understand the technology. At all sites, there were questions raised by regulators, interest group representatives, and technology users about how the technology works, its technical complexity, and its "high-tech" nature. Concern was also raised about the radioactive elements of the process, with indications that $\mathrm{X}$-ray placarding and the technology's electron beams might cause public concern.

\section{Tribal Rights and Future Land Uses}

No comments about tunable hybrid plasma were received specific to this category.

\section{$\underline{\text { Socio-Economic Interests }}$}

Only one comment was received related to socio-economic interests. An INEL interest group representative stated a preference for technologies that do not require a large labor force.

\section{Compatibility with Cleanup Milestones}

A Hanford interest group representative questioned how tunable hybrid plasma would support existing cleanup milestones. The concern expressed was how the demonstration would coordinate with the ongoing Expedited Removal Action at Hanford's 200 West Area, with a request to quantify effects on other remediation systems as they function in parallel with tunable hybrid plasma. No specific comments on this category were received from the other arid sites.

\section{Regulatory Infrastructure and Track Record}

No comments about tunable hybrid plasma were received specific to this category. 


\section{$\underline{\text { Regulatory Compliance }}$}

Hanford stakeholders raised no specific issues about the ability of tunable hybrid plasma to comply with regulatory requirements. At Rocky Flats, interest group representatives expressed concern about regulatory requirements for combined contaminants, and cautioned against just meeting regulatory requirements for single contaminants considered in isolation. A Colorado regulator questioned whether the regulatory framework would support the use of tunable hybrid plasma, and whether the end-product salt would be regulated as a hazardous waste because it will be derived from a hazardous waste.

Permitting questions raised by New Mexico regulators related to the permitting of the tunable hybrid plasma unit itself. Technology users suggested that the source of power for the technology may have regulatory requirements, and the Clean Air Act may require air permits because of off-gas releases.

Table 6 on the following pages summarizes comments on tunable hybrid plasma received by stakeholders at the other arid sites, organized by criterion category. 
Table 6 - TUNABLE HYBRID PLASMA COMMENT LISTING

\begin{tabular}{|c|c|c|}
\hline ISSUES BY CATEGORY & $\begin{array}{l}\text { SITES WHERE ISSUES } \\
\text { RAISED }\end{array}$ & $\begin{array}{l}\text { STAKEHOLDER } \\
\text { CATEGORIES }\end{array}$ \\
\hline $\begin{array}{l}\text { Remaining Contamination } \\
\text { - Assess the ability of the technology to } \\
\text { handle a mixture of VOCs, heavy } \\
\text { metals, and radionuclides. } \\
\text { Evaluate the achievable level of } \\
\text { destruction; it should attain a } \\
99.9999 \% \text { destruction removal } \\
\text { efficiency (DRE). Evaluate the } \\
\text { possibility of multiple passes through } \\
\text { the technology.to obtain higher DRE. }\end{array}$ & $\begin{array}{ll}\cdot & \text { INEL } \\
\text { - } & \text { Sandia } \\
& \\
\text { - } & \text { NNEL } \\
-\quad & \text { Rocky Flats } \\
\text { - } & \text { Sandia }\end{array}$ & $\begin{array}{ll}\text { - } & \text { Technology User } \\
\text { Interest Group } \\
\text { - } & \text { Technology User } \\
& \text { Technology User } \\
\text { - } \quad & \text { Regulator } \\
\text { Interest Group } \\
\text { Technology User }\end{array}$ \\
\hline \multicolumn{3}{|l|}{ Process Waste } \\
\hline $\begin{array}{l}\text { Assess the potential for producing } \\
\text { ozone and secondary wastes and } \\
\text { residues that will need disposal, and } \\
\text { determine the quantity of these wastes. }\end{array}$ & $\begin{array}{l}\text { - } \quad \text { Los Alamos } \\
\text { Rocky Flats } \\
\text { - } \quad \text { Sandia }\end{array}$ & $\begin{array}{ll}- & \text { Regulator } \\
\text { - } & \text { Interest Group } \\
\text { Public Official } \\
\text { - } & \text { Regulator }\end{array}$ \\
\hline $\begin{array}{l}\text { Define the nature of the resulting salt } \\
\text { cake, its purity, the volume to be } \\
\text { generated, and whether it contains any } \\
\text { residual VOC contamination. Do by- } \\
\text { products create a hazard in the brine? }\end{array}$ & $\begin{array}{ll}\text { - } & \text { Rocky Flats } \\
\text { - } & \text { Sandia }\end{array}$ & $\begin{array}{ll}\text { - } & \text { Interest Group } \\
& \text { Regulator } \\
\text { Technology User } & \text { Tribes } \\
\text { - } \quad \text { Regulator } \\
\text { Interest Group }\end{array}$ \\
\hline $\begin{array}{l}\text { Evaluate the potential market for } \\
\text { recycling the salt and brine solutions. }\end{array}$ & $\begin{array}{ll}\text { - } & \text { INEL } \\
& \\
\text { - } & \text { Los Alamos } \\
\text { - } & \text { Rocky Flats } \\
\text { Sandia }\end{array}$ & $\begin{array}{ll}\text { - } & \text { Interest Group } \\
& \text { Regulator } \\
\text { Tribes } \\
\text { - } \quad \text { Tribes } \\
\text { - } \quad \text { Interest Group } \\
\text { Regulator }\end{array}$ \\
\hline $\begin{array}{l}\text { Assess the ability to safely dispose of } \\
\text { resulting salt. What will the salt do to } \\
\text { the chemistry of a landfill? }\end{array}$ & $\begin{array}{l}\text { - } \quad \text { NEL } \\
\text { - } \quad \text { Sandia }\end{array}$ & $\begin{array}{ll}\text { - } & \text { Interest Group } \\
\text { Regulator } \\
\text { - } \quad \text { Interest Group }\end{array}$ \\
\hline $\begin{array}{l}\text { Assess whether elements may } \\
\text { recombine in the technology's reaction } \\
\text { chamber to form different residuals, } \\
\text { and evaluate the formation of PICs } \\
\text { (products of incomplete combustion). }\end{array}$ & $\begin{array}{ll}- & \text { INEL } \\
\text { - } & \text { Rocky Flats } \\
\text { - } & \text { Sandia }\end{array}$ & $\begin{array}{ll}\text { - } & \text { Technology User } \\
- & \text { Interest Group } \\
\text { Technology User }\end{array}$ \\
\hline
\end{tabular}




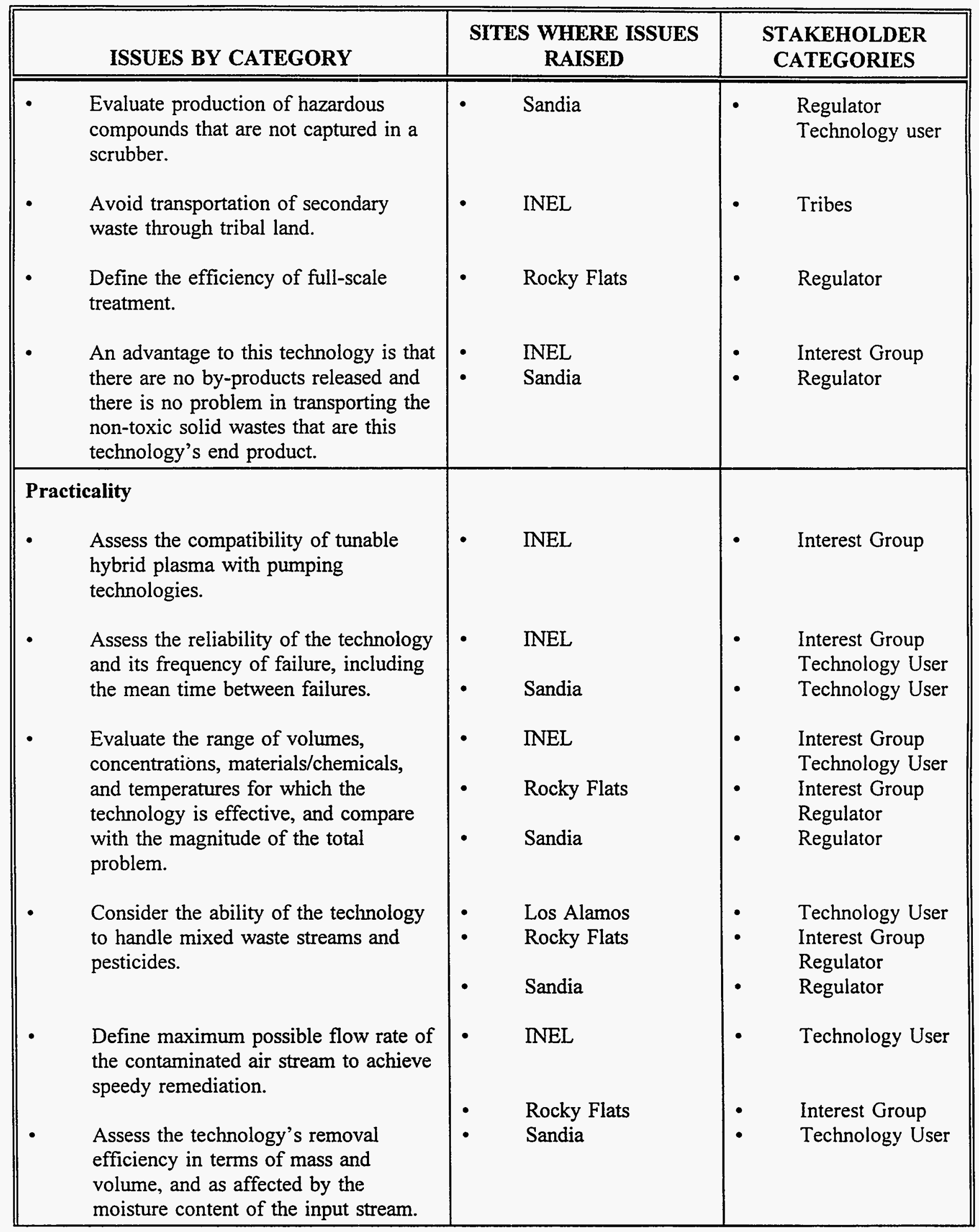




\begin{tabular}{|c|c|c|}
\hline ISSUES BY CATEGORY & $\begin{array}{l}\text { SITES WHERE ISSUES } \\
\text { RAISED }\end{array}$ & $\begin{array}{l}\text { STAKEHOLDER } \\
\text { CATEGORIES }\end{array}$ \\
\hline $\begin{array}{l}\text { Assess the effectiveness of the } \\
\text { scrubbers and their need for } \\
\text { maintenance. }\end{array}$ & $\begin{array}{ll}- & \text { INEL } \\
- & \text { Rocky Flats }\end{array}$ & $\begin{array}{l}\text { - } \quad \text { Technology User } \\
\text { - Interest Group }\end{array}$ \\
\hline $\begin{array}{l}\text { Evaluate maintenance needs and costs, } \\
\text { such as for scrubber clogging, dryer } \\
\text { fouling, and the production of acid } \\
\text { gases in the chamber. }\end{array}$ & $\begin{array}{ll}\text { - } & \text { Los Alamos } \\
\text { - } & \text { Sandia } \\
& \text { Rocky Flats }\end{array}$ & $\begin{array}{ll}\text { - } & \text { Technology User } \\
\text { - } & \text { Regulator } \\
\text { Technology User }\end{array}$ \\
\hline $\begin{array}{l}\text { Evaluate power needs and the purity } \\
\text { required of the power source, } \\
\text { recognizing the difficulty of providing } \\
\text { power to remote locations. }\end{array}$ & Los Alamos & $\begin{array}{l}\text { Regulator } \\
\text { Technology User }\end{array}$ \\
\hline $\begin{array}{l}\text { Evaluate the ability to recirculate the } \\
\text { air stream to control efficiency. }\end{array}$ & Los Alamos & Technology User \\
\hline $\begin{array}{l}\text { Define potential malfunctions and } \\
\text { failures (leaks, formation of harmful } \\
\text { compounds, combustion, explosion), } \\
\text { including those caused by co- } \\
\text { contaminants. }\end{array}$ & Sandia & $\begin{array}{l}\text { Interest Group } \\
\text { Technology User }\end{array}$ \\
\hline $\begin{array}{l}\text { Assess the durability of the unit and } \\
\text { the trailer in high wind and severe } \\
\text { weather. }\end{array}$ & $\begin{array}{ll}- & \text { Sandia } \\
\text { - } & \text { Rocky Flats }\end{array}$ & $\begin{array}{ll}- & \text { Interest Group } \\
\text { - } & \text { Public Official }\end{array}$ \\
\hline $\begin{array}{l}\text { Define the skills and training needed } \\
\text { for workers. There is concern about } \\
\text { the highly technical skills needed to } \\
\text { operate the technology. }\end{array}$ & Sandia & Regulator \\
\hline $\begin{array}{l}\text { Define the schedule and requirements } \\
\text { for adjusting the electron beam. }\end{array}$ & Rocky Flats & Regulator \\
\hline $\begin{array}{l}\text { Assess the potential for titanium foil to } \\
\text { become coated and block the pass- } \\
\text { through of electrons. }\end{array}$ & Rocky Flats & Technology User \\
\hline $\begin{array}{l}\text { Assess the portability of the full-scale } \\
\text { technology. }\end{array}$ & Sandia & Interest Group \\
\hline $\begin{array}{l}\text { Evaluate alternative sources for the } \\
\text { technology; there appear to be multiple } \\
\text { vendors. }\end{array}$ & Sandia & Technology User \\
\hline
\end{tabular}




\begin{tabular}{|c|c|c|}
\hline ISSUES BY CATEGORY & $\begin{array}{c}\text { SITES WHERE ISSUES } \\
\text { RAISED } \\
\end{array}$ & $\begin{array}{l}\text { STAKEHOLDER } \\
\text { CATEGORIES }\end{array}$ \\
\hline $\begin{array}{l}\text { Evaluate security requirements to } \\
\text { prevent vandalism. }\end{array}$ & Sandia & Technology User \\
\hline $\begin{array}{l}\text { Evaluate the trailer size needed to } \\
\text { support the technology; a } 40-\mathrm{ft} \text { trailer } \\
\text { is too big. }\end{array}$ & Sandia & Technology User \\
\hline $\begin{array}{l}\text { Compare tunable hybrid plasma with } \\
\text { the catalytic oxidation (cat-ox) unit } \\
\text { used at INEL in terms of cost, time, } \\
\text { efficiency, power needs, maintenance, } \\
\text { and down time. }\end{array}$ & INEL & Regulator \\
\hline \multicolumn{3}{|l|}{ Works as Intended } \\
\hline $\begin{array}{l}\text { Define the technology's efficiencies } \\
\text { and assess whether efficiency changes } \\
\text { with different input parameters and } \\
\text { when the technology is tuned. Express } \\
\text { the destruction efficiency in terms of } \\
\text { mass removal, and define the range of } \\
\text { concentrations at which the technology } \\
\text { is effective. }\end{array}$ & $\begin{array}{l}\text { - } \quad \text { Rocky Flats } \\
\text { - } \quad \text { Sandia }\end{array}$ & $\begin{array}{l}\text { Interest Group } \\
\text { Regulator } \\
\text { Interest Group } \\
\text { Technology User }\end{array}$ \\
\hline $\begin{array}{l}\text { Evaluate the effectiveness of the } \\
\text { scrubber. }\end{array}$ & Sandia & Interest Group \\
\hline $\begin{array}{l}\text { Compare the effectiveness of the } \\
\text { technology directly with competing } \\
\text { technologies. }\end{array}$ & Sandia & Technology User \\
\hline $\begin{array}{l}\text { Document the ability of the technology } \\
\text { to destroy trichloroethane (TCE) and } \\
\text { the costs to do so. }\end{array}$ & Rocky Flats & Interest Group \\
\hline $\begin{array}{l}\text { Evaluate the effects of metals and } \\
\text { radionuclides on the unit, and assess } \\
\text { the need for handling if they pass } \\
\text { through untreated. }\end{array}$ & Sandia & Technology User \\
\hline $\begin{array}{l}\text { A significant benefit is that the } \\
\text { technology destroys contamination on- } \\
\text { site, and does not transfer it to another } \\
\text { environmental medium. }\end{array}$ & Rocky Flats & Regulator \\
\hline
\end{tabular}




\begin{tabular}{|c|c|c|}
\hline ISSUES BY CATEGORY & $\begin{array}{l}\text { SITES WHERE ISSUES } \\
\text { RAISED }\end{array}$ & $\begin{array}{l}\text { STAKEHOLDER } \\
\text { CATEGORIES }\end{array}$ \\
\hline $\begin{array}{l}\text { Evaluate the ability to capture some } \\
\text { heat from the process and use it for } \\
\text { another purpose. Assess where heat is } \\
\text { exhausted. }\end{array}$ & Sandia & Technology User \\
\hline $\begin{array}{l}\text { Evaluate the entire treatment train, } \\
\text { including costs, risks, and worker } \\
\text { safety. }\end{array}$ & Sandia & Technology User \\
\hline $\begin{array}{l}\text { Determine whether lines from } \\
\text { extraction wells can be run to the } \\
\text { technology or if more than one unit is } \\
\text { needed. }\end{array}$ & - $\quad$ INEL & Technology User \\
\hline $\begin{array}{l}\text { This technology would be of interest } \\
\text { to environmental restoration staff at } \\
\text { Rocky Flats because of the difficulty } \\
\text { of treating carbon tetrachloride at the } \\
\text { site. }\end{array}$ & Rocky Flats & Regulator \\
\hline
\end{tabular}




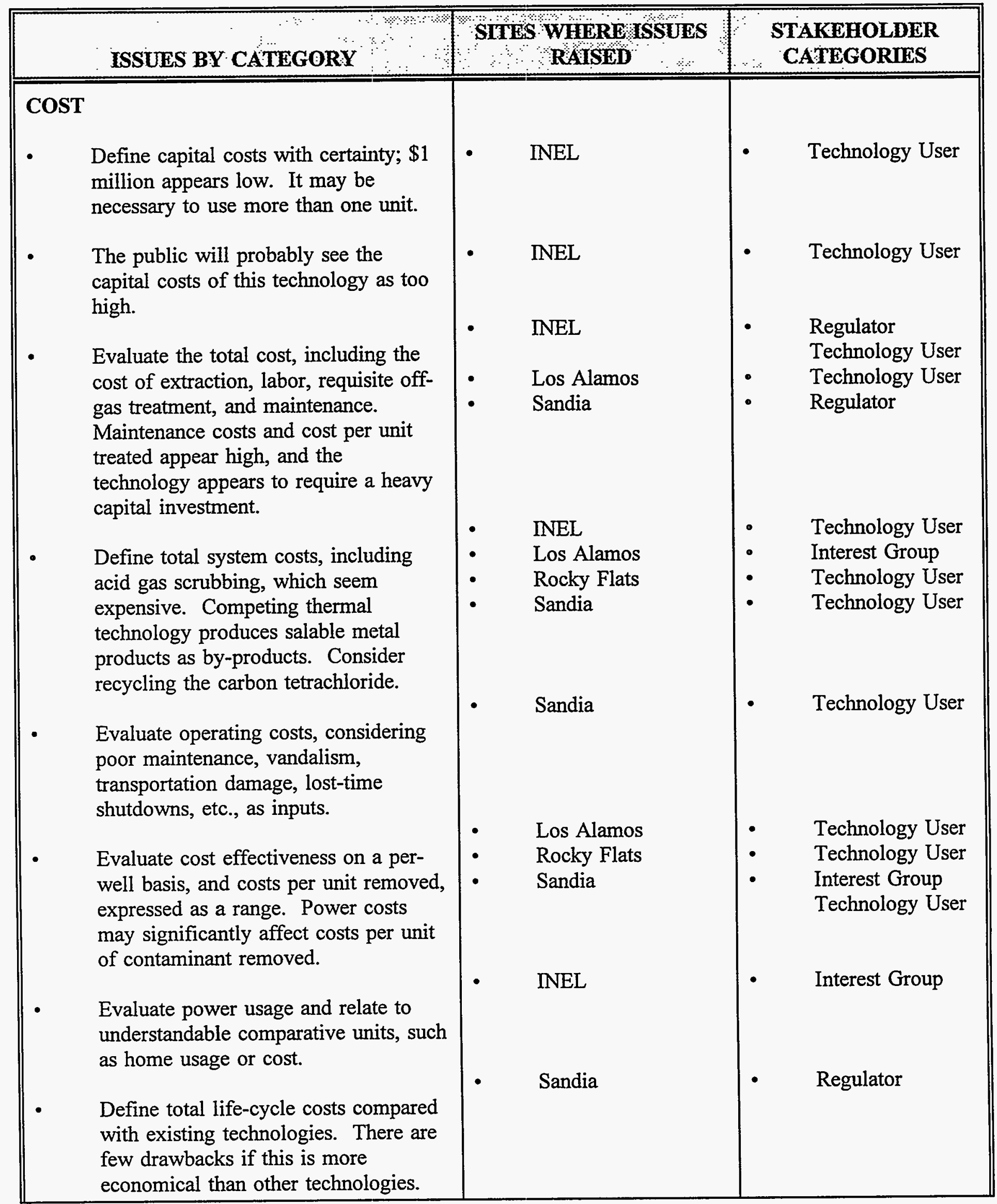




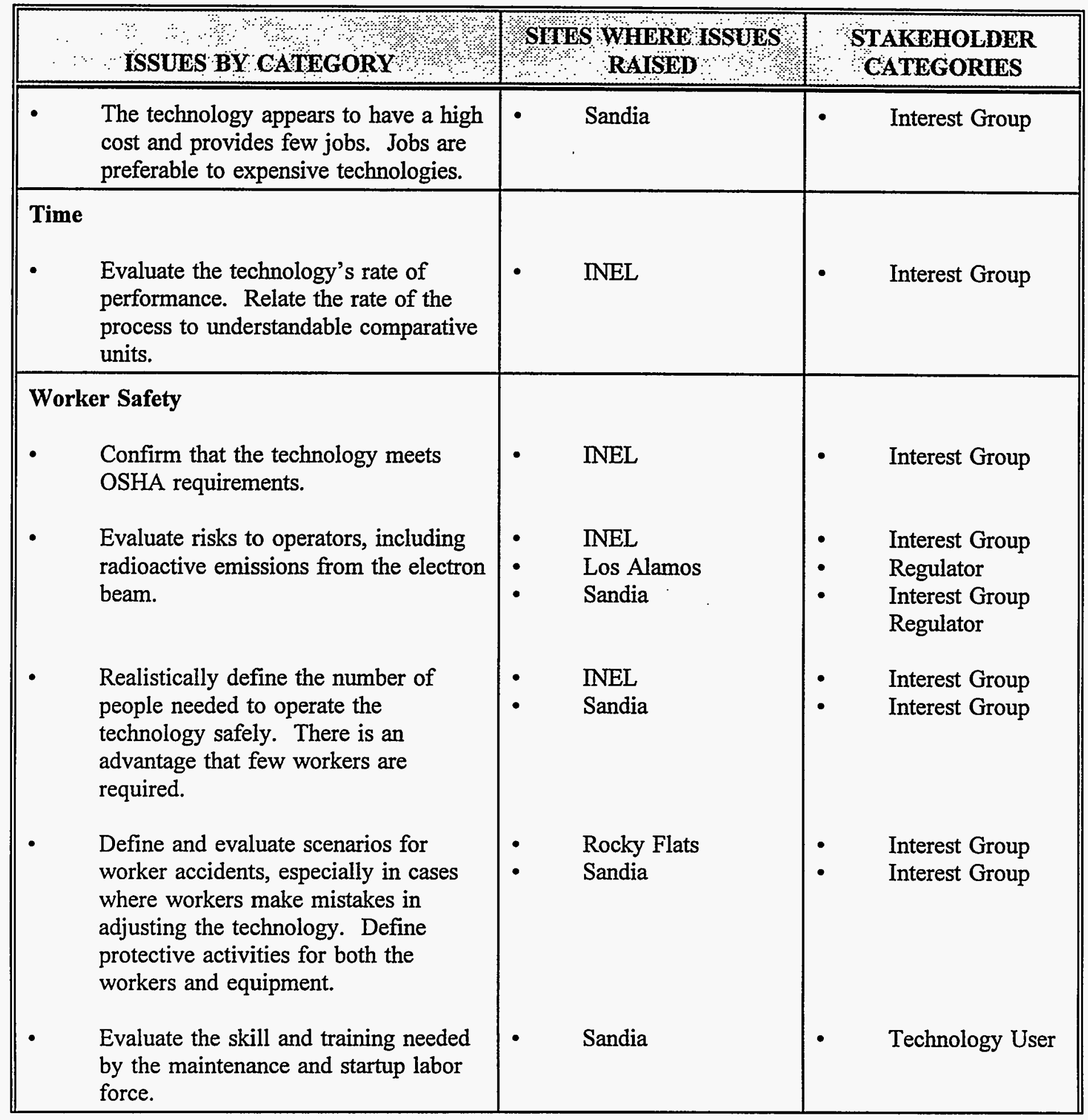




\begin{tabular}{|c|c|c|c|}
\hline & ISSUES BY CATEGORY & $\begin{array}{l}\text { SHYES WIHERE ISSUES } \\
\text { RATSED }\end{array}$ & $\begin{array}{l}\text { STAKEHOLDER } \\
\text { CATEGORIES }\end{array}$ \\
\hline \multicolumn{4}{|c|}{ Public Health and Safety } \\
\hline - & $\begin{array}{l}\text { It is important to evaluate air } \\
\text { emissions, including the } \\
\text { characterization, capture, and treatment } \\
\text { of stack gas. }\end{array}$ & $\begin{array}{ll}\text { - } & \text { INEL } \\
\text { - } & \text { Los Alamos } \\
\text { - } & \text { Sandia }\end{array}$ & $\begin{array}{ll}\text { - } & \text { Interest Group } \\
\text { - } & \text { Tribes } \\
\text { - } & \text { Technology User } \\
& \text { Interest Group }\end{array}$ \\
\hline - & $\begin{array}{l}\text { Evaluate the technology's ability to } \\
\text { meet state air standards. Stack gas } \\
\text { control is a major issue. }\end{array}$ & Los Alamos & Technology User \\
\hline - & $\begin{array}{l}\text { Define the possibility of dioxins or } \\
\text { furans being formed and released. }\end{array}$ & & Interest Group \\
\hline • & $\begin{array}{l}\text { This technology has been used in other } \\
\text { applications. If the usual safeguards } \\
\text { are in place, there is no problem with } \\
\text { its use. }\end{array}$ & Rocky Flats & Regulator \\
\hline • & $\begin{array}{l}\text { Evaluate the formation of products of } \\
\text { incomplete combustion (PICs), } \\
\text { especially with fuels as co- } \\
\text { contaminants. }\end{array}$ & Sandia & Technology User \\
\hline \multicolumn{4}{|c|}{ Environmental Impacts } \\
\hline - & $\begin{array}{l}\text { Define power needs and cost, and the } \\
\text { needs for input resources. Will the } \\
\text { technology have an inordinately high } \\
\text { energy demand or effect neighboring } \\
\text { power flows? }\end{array}$ & $\begin{array}{ll}\text { - } & \text { INEL } \\
\text { - } & \text { Los Alamos } \\
\text { - } & \text { Rocky Flats } \\
\text { - } & \text { Sandia }\end{array}$ & $\begin{array}{ll}\text { - } & \text { Interest Group } \\
& \text { Technology User } \\
\text { - } & \text { Public Official } \\
\text { - } & \text { Technology User } \\
\text { Interest Group } \\
\text { Technology User }\end{array}$ \\
\hline • & $\begin{array}{l}\text { Evaluate the aesthetic effect of the } \\
\text { technology, including power lines (or } \\
\text { find an alternative, low-energy power } \\
\text { source). }\end{array}$ & $\begin{array}{ll}\text { - } & \text { Los Alamos } \\
\text { - } & \text { Sandia }\end{array}$ & $\begin{array}{ll}- & \text { Public Official } \\
\text { - } & \text { Interest Group }\end{array}$ \\
\hline - & $\begin{array}{l}\text { Evaluate noise and the exhaust } \\
\text { emissions from the on-site generator } \\
\text { used for power. }\end{array}$ & Sandia & Technology User \\
\hline
\end{tabular}




\begin{tabular}{|c|c|c|c|}
\hline & ISSUES BY CATEGORY & $\begin{array}{l}\text { SITES WHERE ISSUES } \\
\text { RATSED }\end{array}$ & $\begin{array}{l}\text { STAKEHOLDER } \\
\text { CATEGORIES }\end{array}$ \\
\hline \multicolumn{4}{|c|}{ Public Perception } \\
\hline & $\begin{array}{l}\text { This technology is preferred because it } \\
\text { destroys toxic compounds. }\end{array}$ & INEL & Interest Group \\
\hline - & $\begin{array}{l}\text { The technology's name does not } \\
\text { illustrate its function. The name has } \\
\text { connotations unrelated to the } \\
\text { technology. }\end{array}$ & $\begin{array}{ll}- & \text { INEL } \\
\text { - } & \text { Sandia }\end{array}$ & $\begin{array}{ll}\text { - } & \text { Interest Group } \\
& \text { Interest Group } \\
& \text { Regulator }\end{array}$ \\
\hline • & $\begin{array}{l}\text { The public will be concerned about the } \\
\text { possibility of radioactive emissions } \\
\text { from the electron beam. The } \\
\text { technology should be deployed away } \\
\text { from populations. }\end{array}$ & $\begin{array}{ll}\text { - } & \text { Los Alamos } \\
\text { - } & \text { Sandia }\end{array}$ & $\begin{array}{ll}- & \text { Regulator } \\
- & \text { Regulator } \\
& \text { Technology User }\end{array}$ \\
\hline$\bullet$ & $\begin{array}{l}\text { Similarities to incineration, with off- } \\
\text { gas emissions, may make the } \\
\text { technology unacceptable. Evaluate the } \\
\text { ability to fully control the process. }\end{array}$ & $\begin{array}{ll}\text { - } & \text { INEL } \\
\text { Los Alamos }\end{array}$ & $\begin{array}{ll}\text { - } & \text { Regulator } \\
\text { - } & \text { Technology User }\end{array}$ \\
\hline • & $\begin{array}{l}\text { Demonstrate how the "tunability" of } \\
\text { the technology works. Provide a cut- } \\
\text { away model of the technology. }\end{array}$ & Rocky Flats & Interest Group \\
\hline • & $\begin{array}{l}\text { This is a difficult technology to } \\
\text { understand. }\end{array}$ & Sandia & $\begin{array}{l}\text { Interest Group } \\
\text { Regulator }\end{array}$ \\
\hline • & $\begin{array}{l}\text { The technology's small size is an } \\
\text { advantage. }\end{array}$ & Sandia & Interest Group \\
\hline • & $\begin{array}{l}\text { Not much support exists for high-tech, } \\
\text { high-cost, high-energy technologies. }\end{array}$ & Sandia & Technology User \\
\hline \multicolumn{4}{|c|}{ Socio-Economic Interests } \\
\hline & $\begin{array}{l}\text { Technologies are preferred that do not } \\
\text { require a large labor force. }\end{array}$ & INEL & Interest Group \\
\hline
\end{tabular}




\begin{tabular}{|c|c|c|}
\hline ISSUES BY CATEGORY & $\begin{array}{l}\text { SHEES WHERE ISSUES } \\
\text { RAISED }\end{array}$ & $\begin{array}{l}\text { STAKEHOLDER } \\
\text { CATEGORIES }\end{array}$ \\
\hline \multicolumn{3}{|l|}{ Regulatory Compliance } \\
\hline $\begin{array}{l}\text { Will regulations allow the technology's } \\
\text { use? Will the tunable hybrid plasma } \\
\text { unit itself have to be permitted? }\end{array}$ & $\begin{array}{ll}\text { - } & \text { Los Alamos } \\
\text { - } & \text { Rocky Flats }\end{array}$ & $\begin{array}{l}\text { Regulator } \\
\text { Regulator }\end{array}$ \\
\hline $\begin{array}{l}\text { Consider the synergistic effects of } \\
\text { combined contaminants: don't just } \\
\text { meet regulatory requirements for } \\
\text { single contaminants considered in } \\
\text { isolation. }\end{array}$ & Rocky Flats & Interest Group \\
\hline $\begin{array}{l}\text { Determine if the technology's end } \\
\text { product, the salt brine/cake, will be } \\
\text { regulated as a hazardous waste because } \\
\text { it may be considered to be derived } \\
\text { from a hazardous waste. Can it be } \\
\text { disposed of in solid waste landfills? }\end{array}$ & 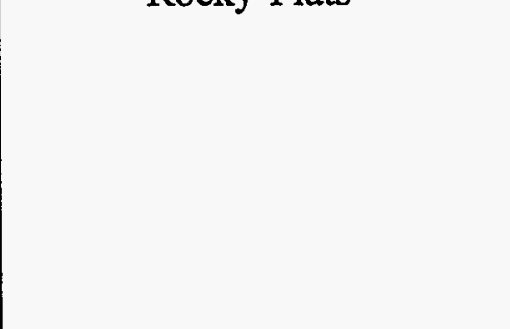 & Public Official \\
\hline $\begin{array}{l}\text { Assess air permitting requirements. } \\
\text { Failure of automated monitors may } \\
\text { cause off-gas releases. }\end{array}$ & Sandia & $\begin{array}{l}\text { Interest Group } \\
\text { Technology User }\end{array}$ \\
\hline $\begin{array}{l}\text { Evaluate regulatory requirements for } \\
\text { the power source for the technology; } \\
\text { an air permit may be needed. }\end{array}$ & Sandia & Technology User \\
\hline
\end{tabular}




\section{APPENDIX A \\ TECHNOLOGY FACT SHEETS AND PROFILES}




\section{SONIC DRILLING}




\title{
VOC-Arid Integrated Demonstration
}

\author{
Fact Sheet: Sonic Drilling
}

\section{Category: Drilling}

Need: Advanced drilling technologies are needed to reduce costs, minimize waste from drilling, and contain drill cuttings and effluents while drilling. Resonant sonic drilling is a promising method for several drilling applications including boring holes for characterization (to determine the location and extent of contamination); drilling groundwater monitoring, vapor, and water extraction wells; installing barrier holes; and obtaining vertical to horizontal continuous core samples.

Description: Resonant sonic drilling has three major components: a drill rig with a sonic head, a drill pipe, and a drill bit. The drill head uses counter-rotating weights to generate energy, which causes the drill pipe to vibrate elastically along its entire length. The drill head operates at frequencies close to the natural frequency of the steel drill column (up to 150 cycles per second). In the resonant condition. forces up to 200,000 pounds are efficiently mansmitted to the drill bit face to create a very effective cutting action. The resonant energy causes sands, gravels, cobbles and even clays to relax into the adjacent formation just enough to permit the drill pipe to advance freely.

As the drill pipe moves through the ground during drilling, the walls of the steel pipe expand and contract helping to reduce any dampening of the vibrations caused by ground swelling. The drill bit can be designed to either push the soils into the borehole wall or modified to allow a continuous core to enter the steel pipe of the drill. Core samples can be continuously retrieved by using either a wireline latch or small inner rod retrieval assembly. No drilling fluid is required with the sonic method. so the only byproduct from drilling is the core sample.

Advantages: The key advantages of the sonic drilling method are that

- the drilling rate is faster

- it contains drill cuttings

- it minimizes secondary drilling waste

- it improves sample quality in formations where the baseline method cannot retrieve high-quality samples (for example, caliche, or boulders)

- it increases safety because workers are exposed to fewer physical hazards and less contamination.

Additionally, sonic drilling decreases contamination of supplemental drilling components (which occurs with systems that require a circulation media), and maintains excellent contamination control at the collar of the borehole. It also drills at any angle. from horizontal to vertical.

Challenges: The major challenge is to improve the reliability of the drill pipe for resonant sonic drilling. A resonance monitoring system will be valuable in determining the threshold energy levels for the drill pipe design. In addition. an accurate measurement system to determine the thermal effects of the bit on the core sample is needed to develop bits that will maintain the temperatures of the contaminants being characterized (for example, to avoid volarilizing organics), while maintaining acceptable penetration rates. Directional drilling applications are also being pursued. 
Counter Rotating Rollers (creates force send down Drill Pipe)

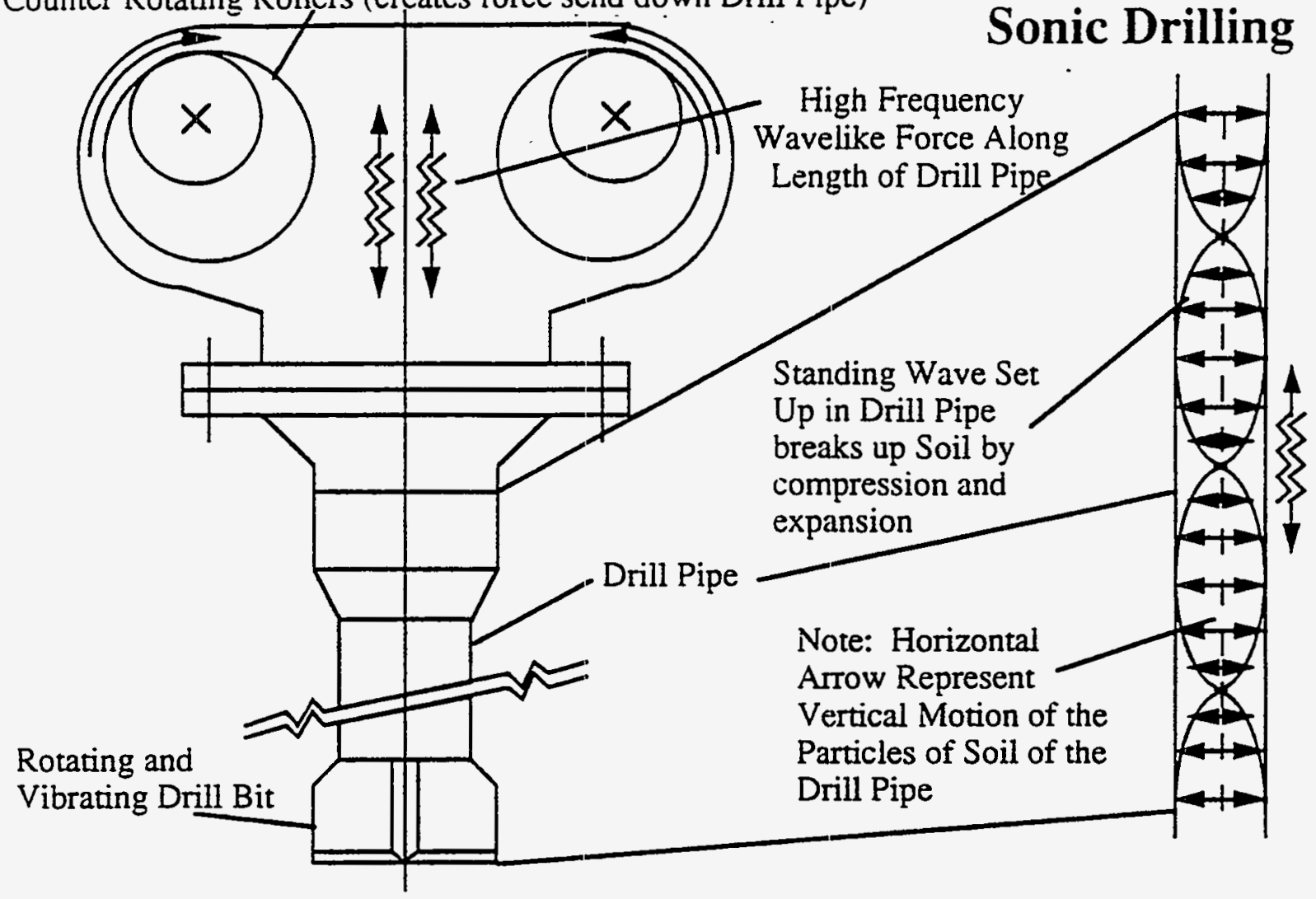




\section{Technology Information Profile: Volatile Organic Compound Offgas Membrane}

Common Name of Technology: Membrane Separation

Principal Investigator: Craig King, (509) 373-2967

Westinghouse Hanford Company

Technology Category: Above-Ground Separation

Developed by: Membrane Technology and Research (MTR) Inc. (Menlo Park. California) and Westinghouse Hanford Company Chemical Engineering Laboratory

\section{Integrated Demonstration Need for the Technology}

The VOC-Arid ID needs cost-effective methods to remove VOCs from gas streams that have been retrieved using techniques such as soil vacuum extraction. The cost of capturing VOCs by carbon adsorption (the technology that is currently used to treat gas streams) is about $\$ 5-15 / \mathrm{b}$ of VOC. Present calculations indicate that the cost of treating emissions by membrane technology will be about $\$ 2-5 / 1 \mathrm{~b}$ of VOC recovered. Also, the 1990 Clean Air Act

Amendments requires that the direct discharge of VOCs be significantly reduced. To decrease the quantity of VOCs discharged to the atmosphere from cleanup activities. this technology or a similar technology needs to be developed.

The most common alternative to this technique is using granular activated carbon (GAC) to adsorb contaminants from gas. This technique generates secondary waste that must be disposed of, and the GAC must be regenerated regularly. The proposed membrane system would minimize the secondary waste and possibly provide a recyclable product.

\section{Technology Objectives}

a. What is the objective of this technology (for example, will this technology destroy volatile organic compounds [VOCs] in groundwater)?

The objective of this technology at Hanford is to remove carbon tetrachloride and chloroform from a gas stream using a vapor membrane separation system. The waste stream will be obtained by vacuum extraction of VOCs from a contaminated soil site. An existing vendor pilot plant will be modified to remove an estimated $95 \%$ of the VOCs in the gas stream. The recovered VOC would be in a liquid form, possibly suitable for reuse or for solvent-recycling programs.

b. What is the technology that is currently used for this application (baseline technology)?

Currently, VOCs in a gas stream are adsorbed onto GAC. 


\section{Technology Application}

a. Where is the technology applied (in situ [in place] or ex situ [above ground])?

This technology is applied above ground

b. What media (soil, groundwater, air) is the technology used in?

This technology is used to separate VOCs from vacuum-extracted offgas streams.

c. What contaminants does the technology target?

The technology targets volatile organic compounds, primarily carbon tetrachloride and chloroform in this demonstration.

\section{Process Description}

After VOCs are removed from the contaminated soil with vacuum extraction, they are treated in a high-pressure system that has been designed to treat feed streams containing dilute concentrations of VOCs. In this system, the feedstream is compressed and sent to a condenser where the liquid solvent is recovered. The stream from the condenser, which contains approximately $5000 \mathrm{ppm}$ of the VOCs, is then sent to the membrane module.

The membrane module is made up of spiral bound modules of thin film membranes separated by plastic mesh spacers; the membrane and the spacers are wound spirally around a central collection pipe. In the membrane module the stream is further concentrated to $25.000 \mathrm{ppm}$ VOC. The concentrated stream is then passed through the system again for a higher VOC recovery rate. The system is operated at the vacuum extraction site.

This technology will not replace the baseline GAC. It will, however, remove $95 \%$ of the VOC vapors before they are passed onto the GAC, so a smaller volume of VOC will be adsorbed on the GAC, thus reducing the overall cost for VOC removal.

a. What is the input to the technology (energy, feedstream for treatment technologies)?

The inputs to this technology are VOCs in a gas stream and electricity to operate the system.

b. What is the output of the technology?

The system produces concentrated carbon tetrachloride in liquid form, which could be recycled. reused, or destroyed. The treated air stream (10 ppm VOCs) is sent through an activated carbon filter and then released to the atmosphere. Approximately $0.4 \mathrm{~kg} / \mathrm{hr}$. of residual liquefied VOC (carbon tetrachloride) will be removed from the system.

\section{Scope of Project (feasibility study, treatability, bench, pilot, field demonstration)}

The technology has been field tested at the VOC-Arid Integrated Demonstration site. 


\section{Summary of Technology Advantages (compared with the baseline technology: Is it faster, better, cheaper,safer?)}

Membrane separation can remove $95 \%$ of the VOCs from the soil vent stream before they are introduced into the GAC, significantly reducing the large amount of secondary waste otherwise generated. The membrane separation technology is less expensive than direct processing with GAC. The cost for capturing VOCs by carbon absorption is about $\$ 5-15 / 1 b$. of VOC. Present calculations using membrane technology estimate costs of $\$ 5 / \mathrm{lb}$. of VOC recovered:

Membrane separation also does not overheat from the heat of adsorption, unlike the GAC process. because the desorption process in the membrane actually removes the heat generated from membrane adsorption. As a result, this system is ideal for high-concentration gas streams (500 to $35,000 \mathrm{ppm})$.

\section{Limitations of Technology (Compared with the Baseline Technology)}

This system is not cost effective when treating gas streams with concentrations below $300 \mathrm{ppm}$.

\section{Major Technical Challenges for the Technology}

Two major challenges confront the membrane separation unit: 1) sizing the pilot plant to handle fluctuations in the VOC flows from the well field and 2) fouling of the membrane with other constituents.

\section{Technical Effectiveness: Performance Criteria}

a. What contamination will remain in the environment after the technology is applied? (Will the mobility of the remaining contamination be reduced? Will the volume be reduced? Will the contaminant be less toxic? This criterion applies primarily to treatment technologies.)

The system removes $95 \%$ of the VOCs in a feedstream containing $1000 \mathrm{ppm}$ of VDCs. The remaining $5 \%$ must be removed using GAC or a similar technology. The VOCs removed are liquid or an aqueous solution and they could be recycled or be destroyed thermally or chemically. Radon contamination was not detected after the field test was completed.

b. What process waste (secondary waste) does the technology produce? (Is the secondary waste mobile? What is its volume? What hazards are associated with the secondary waste? Can it be recycled?)

There will be a secondary waste stream of water contaminated with carbon tetrachlonde. The quantity of water will depend upon the amount of moisture drawn from the soil in the vacuum extraction process. The water can be treated to destroy the VOC.s.

c. Is treatment or storage needed and available for the secondary waste?

Yes. Some available treatment processes are ultraviolet oxidation, incineration. or :set oxidation or VOCs could be shipped offsite to be destroyed. 


\section{(9) d. Is decontamination or decommissioning of equipment required?}

No decontamination or decommissioning is required.

e. Is disposal of secondary waste needed and available?

There is some concern about whether the recovered VOCs can be recycled. but disposal (typically incineration) is available.

f. How practical is the technology? Does it foreclose future cleanup options? (Applies primarily to treatment technologies)

This technology does not foreclose future options for offgas treatment.

g. How reliable is the technology?

There appear to be no major mechanical, corrosion, or process problems that could affect reliability. Most of the system uses standard off-the-shelf equipment that is proven and reliable. The only concern about this system's reliability is the possibility that the membrane will foul during the course of the three-month test. The system had no failures or detectable degeneration of the membranes during the 6 -month pilot test.

h. If the technology fails, can the effects of the failure be controlled easily and quickly?

If the gas membrane system fails, it shuts down automatically. If the vapor extraction system is shut down, the membrane system immediately shuts down also. These sequences are all automatic and require no operator action. The shut-down systems have been tested, and they functioned as designed.

i. How easy is the technology to use?

The membrane system will operate without operator attention for days or weeks at a time. All components for a full-scale plant could be chosen with this requirement in mind. Design will be based on a maintenance schedule to check pumps. compressors. replace oil, etc. approximately three times per month. The size of the unit is $5 \mathrm{ft}$ by $8 \mathrm{ft}$.

j. What infrastructure (buildings, power sources, personnel) is needed to support the technology?

Power is required to operate the system.

k. How versatile is the technology? Can it be applied to other types of contamination. in other media, or at other locations?

This technology is versatile; it can be fed multiple VOCs, although it does not operate as effectively with trichloroethylene and perchloroethylene as with carbon tetrachlonde. The VOC to be treated in the system will affect the efficiency of the membranes. Several VOCs have been tested by MTR for membrane selectivity. As a rule of thumb. the membrane must be at least 10 times as selective to VOC as it is to air to be practucal for application. It also works most efficiently with a feedstream that has low humidity and a higher concentration of VOCs. 
(9) I. Is the technology compatible with other elements of the remediation system?

No compatibility problems exist.

m. Can the technology be procured "off-the-shelf"?

Yes, although MTR is currently the only company in the U.S. that can provide the necessary support equipment. No other companies have any commercial units available. but some are beginning to explore this technology.

n. Is the technology equipment easy to maintain?

Yes. During a recent test of the system, this technology required much less maintenance than the GAC canisters.

o. What safety measures are required to protect workers and the public?

The system is designed to minimize exposure to operators or the environment during operation. If a gas stream line ruptures, a brief release of VOCs to the atmosphere may occur. A lock down system has been designed to turn off the system if a line ruptures.

p. Does the technology work as intended?

The gas membrane system has been shown to operate as expected. During a test of the system, no fouling of the membranes was detected, and it has continued to be effective in removing $95 \%$ or more of the contaminant.

\section{Cost}

a. What is the start-up cost of the technology (including development costs, procurement and construction, permitting, and other costs necessary to begin operation)?

Based on a flow rate of 1000 standard cubic feet per minute (scfm) and a concentration of $1000 \mathrm{ppm}$ of carbon tetrachloride, cost of the system should be approximately $\$ 850.000$ $( \pm 20 \%)$.

b. What are the operations and maintenance costs of the technology?

Membrane replacement may be necessary every 3 years at an estimated cost of $\$ 600,000 /$ membrane.

c. What are the life cycle costs of the technology (including facility capital cost: startup, operation, and maintenance; decommissioning, regulatory, or institutional oversight; and future liability)?

Costs over the life of the system (expected to be approximately 10 years), would be approximately $\$ 6.20 / \mathrm{kg}$ of carbon tetrachloride removed. Costs would be less with higher-concentration feedstreams. 


\section{Time}

a. When will the technology be available?

This technology and system is available now . MTR presently manufactures similar systems for industrial application, and the changes that need to be made to the system for this application are minimal.

b. What is the speed or rate of the technology?

Approximately $10.3 \mathrm{~kg} / \mathrm{hr}$ of residual liquefied VOC (carbon tetrachloride) will be removed, based on a process flow rate of $1000 \mathrm{scfm}$.

c. What is the total time required for setup and removal and the total time for the technology to achieve its objectives?

Time required is not known.

\section{Environmental Safety and Health: Worker Safety}

a. Will workers be exposed to hazardous materials or other hazards?

Workers are not exposed to hazards during normal operations. There is a risk of a drum spill if drums of waste are shipped offsite, but few if any other exposures are anticipated.

b. What are the physical requirements for workers?

Workers must move 55-gallon drums of condensate and VOCs using a forklift.

c. How many people are required to operate the technology?

One forklift operator is needed to move GAC canisters. Maintenance workers will be required to lubricate the pumps and generator and inspect the electrical equipment intermittently.

\section{Environmental Safety and Health: Public Health and Safety}

a. Is there a history of accidents with this technology?

This technology has no history of accidents. There is a risk of a drum spill if drums of waste are shipped offsite.

b. Does this technology produce routine releases of contaminants?

Releases of offgas may occur.

c. Are there potential impacts from transportation of equipment, samples, waste. or other materials associated with the technology?

Precautions must be taken if drums are transported to offsite disposal or treatment facilities. 


\section{Environmental Impacts}

a. Will this technology have an impact on the ecology of the area (for example. wildlife, vegetation, air, water, soil, or people)?

No ecological impacts are expected.

b. Does the technology have aesthetic impacts (for example, visual impacts, noise)?

This system is comparable in size and to the GAC system.

c. What natural resources are used in the technology's development, manufacture, or operation?

This system uses no natural resources other than those needed to manufacture components.

d. What are the technology's energy requirements?

This technology requires electricity. The power required will be monitored during the test and reported upon completion of the test.

\section{Socio-Political Interests: Public Perception}

a. What is the reputation of the technology's developer or user?

Not known.

b. Is the technology familiar to the public and easy to understand?

Interested parties and individuals are probably not familiar with this technology. Some information has been published in a few technical journals.

\section{Socio-Political Interests: Tribal Right /Future Land Use}

a. Will the technology affect future unrestricted use of land and water?

No. The area where the system is used must be graded, but grading does not preclude revegetation.

\section{Socio-Economic Interests}

a. What are the potential economic impacts of this technology? (For example, what are the effects on the economic base of the community? Are there infrastructure requirements?)

This system will not have any significant economic impact.

b. Will the technology affect labor force demands?

The system will not have significant labor demands. 


\section{Regulatory Objectives}

a. Is the technology compatible with cleanup milestones?

If the two principal challenges (sizing the unit to handle VOC flow fluctuations and eliminating or mitigaring membrane fouling) can be addressed, this technology should be compatible with cleanup milestones.

b. Are regulators familiar with this or a similar technology ? What is the technology's regulatory track record?

This technology has not been tested, so regulators are not very familiar with it.

c. Does the technology comply with applicable regulations?

Yes. This system would serve as a "pretreatment" for the GAC by removing approximately $95 \%$ of the VOCs. The membrane separation system would not replace GAC but would simply reduce the demand on the GAC. GAC is an acceptable technology to the state of Washington and EPA and is believed to be capable of meeting all applicable regulatory requirements.

\section{Industrial Partnerships}

a. What is the name of the industrial partner?

MTR manufactures the membrane and skids, and Westinghouse Hanford leases the equipment from MTR. MTR is primarily a research organization.

b. What is the rationale for this partnership?

Not applicable.

c. What is the contract mechanism?

Westinghouse Hanford leases equipment from MTR. MTR also provides technicaل support as part of this agreement.

d. Are there other potential partners?

The biggest cost-sharing opportunity is with companies interested in technology for recycling solvent vapors. British Petroleum is looking for technology to recycle fuguuve gasoline storage tank emissions: Texaco has also been exploring this technology. Vany industries have clean-up sites that are contaminated with chlorinated VOCs.

e. Are there potential international partners?

British Petroleum is a potential partner. 


\section{Intellectual Property}

a. Who owns the patent for this technology?

MTR owns the patent.

b. Are there other patent owners?

No, there are not other patent owners.

c. Is there a patent number for this technology?

There are several patent numbers.

\section{Cost Sharing}

a. What is the background of this technology? (Where did the idea come from? Who else is doing similar work? What have the results been to date? What is the most significant competitor to this technology?)

MTR has been developing membrane vapor separation systems for 7 years: they have manufactured six pilot plants and three commercial systems. EPA has also funded and been involved in the development of membrane separation. The technology was originally developed in Germany about 10 years ago. MTR introduced the technology in the United States, and they have a patent on the membrane. The membrane vapor separation systems that have been built are one-stage and two-stage systems. A proposed three-stage system will be conceptually the same as those built at the pilot and commercial scale. High-pressure models of the type proposed for the VOC-Arid ID have been in operation in one of MTR's commercial installations for several months. 
IN-SITU BIOREMEDIATION 
VOC-Arid Integrated Demonstration

\section{Fact Sheet: In Situ Bioremediation of Groundwater}

\section{Category: In Situ Remediation Technologies}

Need: In order to. remediate groundwater that has been contaminated, it currently must be pumped from the ground and treated. This process is difficult and expensive; therefore. more cost-effective and efficient methods, particularly methods that treat contaminants in place, must be developed. In situ bioremediation is being developed to stimulate the growth of naturally occurring organisms that can degrade and detoxify chemical contamination in place in the soils and groundwater. Bioremediation can also be used to augment other physical or chemical treatment techniques such as in situ vapor stripping (which removes contaminants from groundwater in a gas stream). Bioremediation may also be effective to enhance the treatment of remaining contamination from bulk contaminant removal operations.

Description: Native microorganisms can be stimulated with acetate to consume and degrade carbon tetrachloride and nitrates in soils and groundwater. In laboratory, bench, and pilot-scale tests, it has been demonstrated that $99 \%$ of nitrates and $93 \%$ of carbon tetrachloride contamination in groundwater can be degraded.

The in situ bioremediation process injects acetate and nitrate (as needed after initial nitrate levels are depleted) through a series of injection wells or injection well screens as part of a multi-screened mixing well. These nutrients are mixed with the groundwater in a way that will maximize contaminant degradation and minimize excessive microbial growth around the well. The injected nutrients produce an active zone of organisms that will degrade contaminants as they are pumped through the treatment zone.

The system can use a series of injection and extraction wells to mix contaminated groundwater with nutrients and microorganisms or the system can use one or more multi-screened mixing wells to mix the water. nutrients, and microorganisms without pumping water to the surface. The residual effect on the aquifer of applying this technology will be increased levels of naturally occurring microorganisms. If a series of extraction and injection wells is used (rather than the mixing wells), the output of the system at the surface would include carbon dioxide, nitrogen gas, and excess biomass (microorganisms).

The planned demonstration will use multiscreened mixing wells and will decrease the amount of groundwater that must be removed. The multi-screened mixing wells are similar to the multi-screened wells used for the in situ VOC removal system using air sparging. Therefore, the two technologies could be used one after the other for combined physical and biological treatment of VOCs and nitrates.

Advantages: In situ bioremediation is potentially beneficial for treating VOCs and other contaminants that are held in soils that adsorb them well or in less permeable silts, sediments, and clays that retain the contaminants. Bioremediation destroys the VOCs in place and is more effective in these conditions than pumping the groundwater and treating above ground.

The time and cost of clean-up could be substantially reduced if bioremediation can be used effectively alone or in conjunction with other removal technologies. Present conservative estimates (based on very permeable soils, and groundwater with VOC contaminants only, with no nitrate) indicate that this technology will be faster and safer than the baseline methods but will cost about the same as pumpand-treat technologies for volume of soil remediated. Bioremediation is safer because no contaminated media must be brought to the 
surface and the technology provides ultimate on-site destruction of the contaminant, converting the hazardous compounds to nonhazardous products.

This treatment method could also reduce further spread of contamination because the increased numbers of microorganisms will reduce the soil permeability, and therefore. reduce the rate of movement of VOCs out of and into the contaminated zone. It is expected that if the cost/benefit analysis includes the baseline cost of trearing nitrates in addition to V.OCs, bioremediation costs would be significantly less than pump and treat technologies. Other advantages include

- decreased worker exposure to chemical contaminants

- slower or no movement of radionuclides in the groundwater

- higher likelihood of acceptance because bioremediation it is a natural process.
Challenges: Several key technical issues have prevented widespread use of bioremediation for organic and inorganic subsurface contaminants, including adequate nutrient delivery systems: effective mixing technologies for contacting microorganisms, nutrients, and contaminants; control of excessive microbial growth: and adequate tools for designing, predicting, and monitoring the performance of in situ technologies in varied subsurface environments.

The goal of this program is to address these technical issues in a demonstration by stimulating native microorganisms and accelerating the natural degradation of nitrate. carbon terrachloride.and chloroform. Another major challenge of any in situ remediation process is being able to effectively monitor the process to confirm whether the technology is effective. Also, carbon tetrachloride is difficult to degrade. This effort will be one of the first to demonstrate destruction of this VOC under conditions that reduce nitrate. 


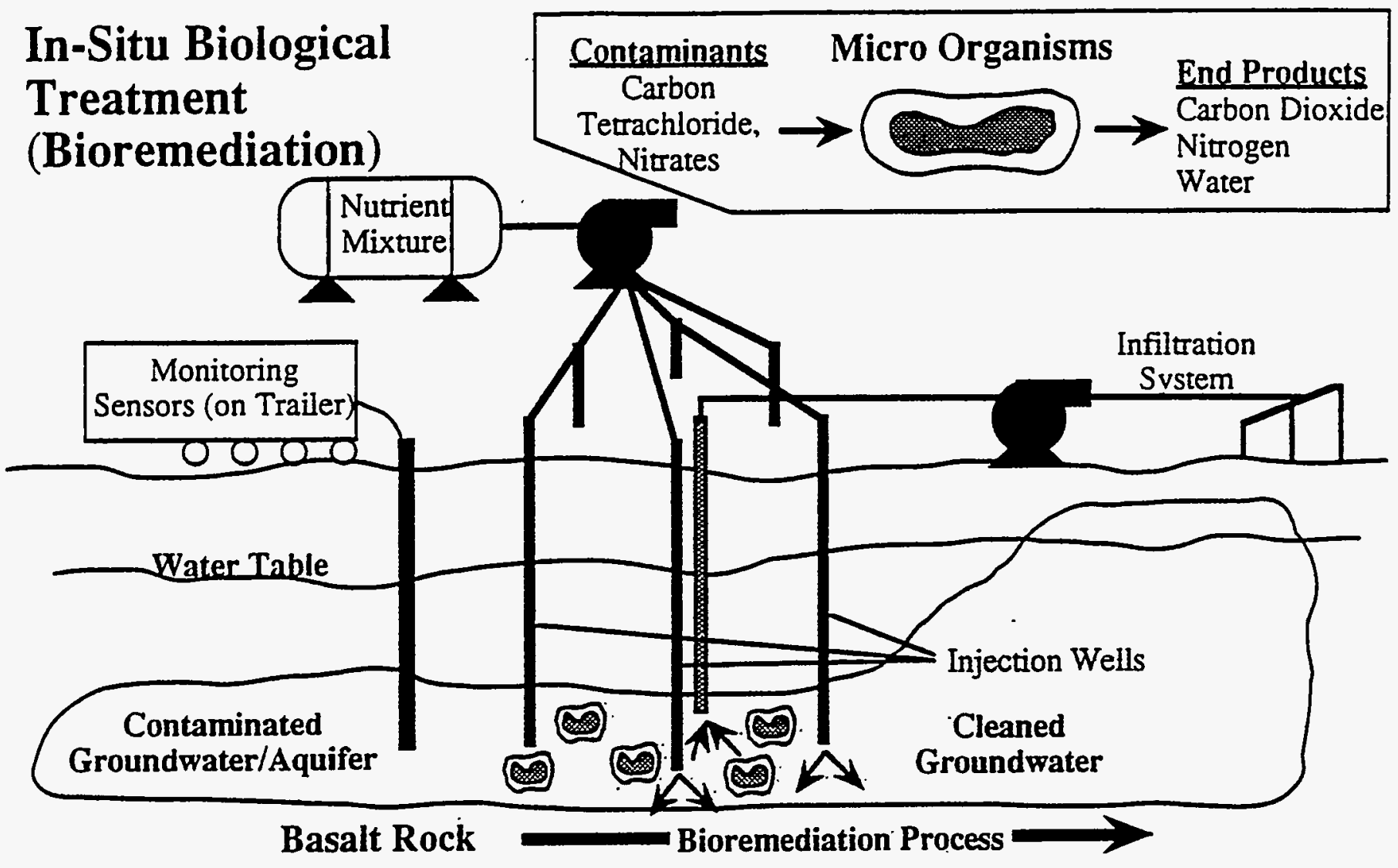




\section{Technology Information Profile: In Situ Bioremediation of Groundwater}

Common Name of Technology: In Situ Bioremediation of Groundwater

Principal Investigator: T.M. Brouns, (509) 376-7855

R.S. Skeen, (509) 376-6371

Pacific Northwest Laboratory

Technology Category: In Situ Remediation Technologies

Developed by: Pacific Northwest Laboratory, Rice University, University of Idaho, Washington State University, Stanford University, University of Washington

\section{Integrated Demonstration Need for the Technology}

In order to remediate groundwater that has been contaminated, it currently must be pumped from the ground and treated. This process is difficult and expensive; therefore, more costeffective and efficient methods, particularly methods that treat contaminants in place, must be developed. In situ bioremediation is being developed to stimulate the growth of naturally occurring organisms that can degrade and detoxify chemical contamination in place in the soils and groundwater. Bioremediation can also be used to augment other physical or chemical treatment techniques such as in situ vapor stripping (which removes contaminants from groundwater in a gas stream). Bioremediation may also be effective to enhance the treatment of remaining contamination from bulk contaminant removal operations.

\section{Technology Objectives}

a. What is the objective of this technology (for example, will this technology destroy volatile organic compounds [VOCs] in groundwater)?

The objective of this technology is to stimulate the growth and metabolism of naturally occurring microorganisms to degrade and detoxify chemical contamination in place in the subsurface and groundwater.

b. What is the technology that is currently used for this application (baseline technology)?

Currently, the groundwater is pumped and treated above ground.

\section{Technology Application}

a. Where is the technology applied (in situ [in place] or ex situ [above ground])?

This is an in situ technology.

b. What media (soil, groundwater, air) is the technology used in? 
This technology is used to treat groundwater contamination.

\section{c. What contaminants does the technology target?}

Carbon tetrachloride, chloroform, and nitrates.

\section{Process Description}

Native microorganisms can be stimulated with acetate to consume and degrade carbon tetrachloride and nitrates in soils and groundwater. In laboratory, bench, and pilot-scale tests. it has been demonstrated that $99 \%$ of nitrates and $93 \%$ of carbon tetrachloride contamination in groundwater can be degraded.

The in situ bioremediation process injects acetate and nitrate (as needed after initial nitrate levels are depleted) through a series of injection wells or injection well screens as part of a multi-screened mixing well. These nutrients are mixed with the groundwater in a way that will maximize contaminant degradation and minimize excessive microbial growth around the well. The injected nutrients produce an active zone of organisms that will degrade contaminants as they are pumped through the treatment zone.

The system can use a series of injection and extraction wells to mix contaminated groundwater with nurrients and microorganisms or the system can use one or more multi-screened mixing wells to mix the water, nutrients, and microorganisms without pumping water to the surface. The residual effect on the aquifer of applying this technology will be increased levels of naturally occurring microorganisms. If a series of extraction and injection wells is used (rather than the mixing wells), the output of the systern at the surface would include carbon dioxide, nitrogen gas, and excess biornass (microorganisms).

The planned demonstration will use multi-screened mixing wells and will decrease the amount of groundwater that must be removed. The multi-screened mixing wells are similar to the multi-screened wells used for the in situ VOC removal system using air sparging. Therefore, the two technologies could be used one after the other for combined physical and biological treatment of VOCs and nitrates.

\section{a. What is the input to the technology (energy, feedstream for treatment technologies)?}

Acetate and nitrate are the nutrients used in this system.

\section{b. What is the output of the technology?}

There are no output streams for this technology because it occurs in place (without removing groundwater). If co-contaminants such as heavy metals or radionuclides are extracted with the groundwater containing VOCs and nitrate groundwater, then conventional treatment techniques may need to be used in addition to the bioremediation. These processes would generate additional secondary waste.

The demonstration will use mixing wells, so no groundwater will be extracted. In this case, if other non-biodegradable co-contaminants were present, they would need to be treated using other technologies. 


\section{Scope of Project (feasibility study, treatability, bench, pilot, field demonstration)}

This project includes a treatability study, bench-scale test, and field demonstration.

\section{Summary of Technology Advantages (compared with the baseline technology: is it faster, better, cheaper,safer?)}

In situ bioremediation is potentially beneficial for treating VOCs and other contaminants that are held in soils that adsorb them well or in less permeable silts, sediments, and clays that retain the contaminants. Bioremediation destroys the VOCs in place and is more effective in these conditions than pumping the groundwater and treating above ground .

The time and cost of clean-up could be substantially reduced if bioremediation can be used effectively alone or in conjunction with other removal technologies. Present conservative estimates (based on very permeable soils, and groundwater with VOC contaminants only, with no nitrate) indicate that this technology will be faster and safer than the baseline methods but will cost about the same as pump-and-treat technologies for volume of soil remediated. Bioremediation is safer because no contaminated media must be brought to the surface and the technology provides ultimate on-site destruction of the contaminant; converting the hazardous compounds to non-hazardous products.

This treatment method could also reduce further spread of contamination because the increased numbers of microorganisms will reduce the soil permeability, and therefore. reduce the rate of movement of VOCs out of and into the contaminated zone. It is expected that if the cost/benefit analysis includes the baseline cost of treating nitrates in addition to VOCs. bioremediation costs would be significantly less than pump and treat technologies. Other advantages include

- decreased worker exposure to chemical contaminants

- slower or no movement of radionuclides in the groundwater

- higher likelihood of acceptance because bioremediation it is a natural process.

\section{Limitations of Technology (Compared with the Baseline Technology)}

The main limitation of this technology when compared with baseline methods is the difficulty of designing and implementing a treatment system that will be effective in a variety of soil types. However, this limitation may be overcome as the technology matures.

\section{Major Technical Challenges for the Technology}

Several key technical issues have prevented widespread use of bioremediation for organic and inorganic subsurface contaminants, including adequate nutrient delivery systems; effective mixing technologies for contacting microorganisms, nutrients, and contaminants; control of excessive microbial growth; and adequate toois for designing, predicting, and monitoring the performance of in situ technologies in varied subsurface environments.

The goal of this program is to address these technical issues in a demonstration by stimulating native microorganisms and accelerating the natural degradation of nitrate, carbon tetrachloride, 
(8) and chloroform. Another major challenge of any in situ remediation process is being able to effectively monitor the process to confirm whether the technology is effective. Also. carbon tetrachloride is difficult to degrade. This effort will be one of the first to demonstrate destruction of this VOC under conditions that reduce nitrate.

\section{Technical Effectiveness: Performance Criteria}

a. What contamination will remain in the environment after the technology is applied? (Will the mobility of the remaining contamination be reduced? Will the volume be reduced? Will the contaminant be less toxic? This criterion applies primarily to treatment technologies.)

The process will destroy nitrates and carbon tetrachloride. Remaining contamination will consist of non-degradable co-contaminants, many of which would be less mobile because the permeability of the aquifer would be reduced.

No byproduct contamination is expected from the remediation process. Chloroform may be produced from the degradation of carbon tetrachloride; however, the process will be designed to further degrade the chloroform to carbon dioxide.

The goal is to reduce the concentration of VOCs to below the drinking water standard of 5 parts per billion (ppb), which is less than the target for pump and treat technologies.

The mobility of remaining VOC contamination, as well as remaining non-degradable cocontaminants, will be reduced because the adsorptive nature of the biomass, as well as reduced permeability of the aquifer caused by the microbial growth and subsequent pore clogging.

b. What process waste (secondary waste) does the technology produce? (Is the secondary waste mobile? What is its volume? What hazards are associated with the secondary waste? Can it be recycled?)

Because the process is in situ, no process wastes are generated from the remediation. The goal of this technology is to eliminate the production of waste at the surface.

c. Is treatment or storage needed and available for the secondary waste?

No secondary waste is generated.

d. Is decontamination or decommissioning of equipment required?

No. Decontamination and decommissioning are not required.

e. Is disposal of secondary waste needed and available?

No secondary waste will be produced. 
(9) f. How practical is the technology? Does it foreclose future cleanup options? (Applies primarily to treatment technologies)

Bioremediation will possibly reduce the permeability of the aquifer and increase the difficulty of using soil flushing operations in the future. The effectiveness of soil flushing technologies, or other technologies that require the addition of reagents, solutions, and .to a lesser extent, air, are generally more effective and easier to use in permeable soils. The permeability of the soils will probably be decreased by the bioremediation process; therefore, subsequent use of these other technologies may be more difficult.

g. How reliable is the technology?

The reliability of the process is not yet known. However, above-ground bioremediation technologies for many organic contaminants enjoy very reliable widespread use.

h. If the technology fails, can the effects of the failure be controlled easily and quickly?

Bioremediation depends on a complex interaction of many variables; however, adequate process controls should minimize potential failure. For example, automatic pump and nutrient feed shut-off systems are used. The most likely failures that might be difficult to manage but would probably have marginal impact would be microbial fouling of well screens and aquifer clogging.

i. How easy is the technology to use?

The process of technology is very simple. There are very few process control variables and inputs to the system, which makes it very easy to operate, but it is difficult to monitor and to design. At the microscopic level, the technology is very complex. Because the process occurs in a loosely defined zone within the subsurface, with very few access points for monitoring, it is difficult to evaluate technical performance and accurately control the system. If the treatability studies, design simulations, and efforts to determine the nature and extent of the contamination have provided adequate data. the technology should be easily operated.

j. What infrastructure (buildings, power sources, personnel) is needed to support the technology?

Bioremediation does not require an extensive infrastructure to operate. The inputs to the system are limited in number, and readily available. Standard support services can provide adequate data, equipment, and materials to effectively implement the bioremediation technology, without a complex added infrasuructure. Energy needs for bioremediation are significantly less than those for the baseline technology because significantly less pumping is required.

k. How versatile is the technology? Can it be applied to other types of contamination, in other media, or at other locations?

Bioremediation and the tools needed to design the systems apply to a wide array of environmental problems. The equipment, design tools, and treatability testing protocols are quite versatile and can be used consistently from one site to another, but the processes (bacteria, nutrients, and operations conditions) are contaminant- and site-specific and are not as versatile as pump and treat technologies. 
(9k) Techniques that increase bioremediation's versatility include using non-native microorganisms with known degradation capability, modifying nutrients and injection strategies to manipulate the environrnent and increase the likelihood of success. or using a combination of other physical and chemical techniques that can be used with the same series of wells and process equipment.

I. Is the technology compatible with other elements of the remediation system?

Many of the most common environmental restoration technologies are compatible with bioremediation. It has traditionally been used with pump and treat technologies. The tools necessary to predict performance, transport, delivery, and mixing or reagents or nutrients are compatible with other in situ technologies.

The tools that are needed for bioremediation are compatible with vapor stripping, chemical treatment, soil flushing, and containment. In addition, bioremediation is a natural enhancement to many of these techniques, including vapor stripping and soil flushing.

\section{m. Can the technology be procured "off-the-shelf"?}

The tools that allow bioremediation to be implemented are readily available, in general. Most of the process equipment and tools necessary to implement bioremediation are available. Specific items such as the design tools, monitoring systems, and well designs are in a state of development, but less sophisticated alternatives are available off-theshelf. As the technology matures, the enhanced tools should quickly become available commercially.

However, bioremediation is more process knowledge than specific hardware. The expertise needed to implement the technology is limited and variable within the environmental community.

n. Is the technology equipment easy to maintain?

The above-ground components are easy to maintain. Daily checks are required for the nutrient supply tanks, pump operations, and sensing devices; however, microbial fouling of the well screen is possible. Careful design should minimize this problem, but if it occurs, maintenance will be difficult.

\section{o. What safety measures are required to protect workers and the public?}

Because this is a low-pressure, low-temperature process that relies upon natural materials for use, no significant safety measures are necessary.

\section{p. Does the technology work as intended?}

Bioremediation of carbon tetrachloride has not yet been adequately demonstrated; therefore, it is not yet known if the technology will work as intended.

Based on laboratory, bench, and pilot studies completed to date, it is expected that the technology will be effective and will operate as designed. Rigorous feasibility studies and modeling to evaluate how sensitive the process is to fluctuations in critical field variables will help to ensure that the process functions as intended. 


\section{Cost}

a. What is the start-up cost of the technology (including development costs, procurement and construction, permitting, and other costs necessary to begin operation)?

Preliminary start-up capital costs are estimated at $\$ 606.000$ (including plant and startup costs). Estimates of costs were based on a conservative, hypothetical test case using a single extraction and single injection well in a permeable soil matrix with approximately $1,000 \mathrm{ppb}$ carbon tetrachloride. The cost information was obtained from R.S. Skeen. S.P. Luttrell, B.S. Hooker, and J.N. Petersen, "In situ bioremediation of Hanford groundwater," Remediation, Summer 1993, pp 353-367.

b. What are the operations and maintenance costs of the technology?

Preliminary operations and maintenance costs are estimated at $\$ 0.54 / \mathrm{day} / \mathrm{m} 3$ of soil volume to be treated. Estimates of costs were based on a conservative, hypothetical test case using a single extraction and single injection well in a permeable soil matrix with approximately $1,000 \mathrm{ppb}$ carbon tetrachloride. Total operations and maintenance costs for this hypothetical case were $\$ 549,000$, given a control soil volume of 3,830 cubic meters and remediation time of 260 days. The cost information was obtained from R.S. Skeen, S.P. Luttrell, B.S. Hooker, and J.N. Petersen, "In situ bioremediation of Hanford groundwater," Remediation. Summer 1993, pp 353-367.

c. What are the life cycle costs of the technology (including facility capital cost; startup, operation, and maintenance; decommissioning, regulatory, or institutional oversight; and future liability)?

Preliminary life cycle costs for the bioremediation process are estimated to be $\$ 250$ per cubic meter of soil volume to be treated. Estimates of costs were based on a conservative. hypothetical test case using a single exuraction and single injection well in a permeable soil matrix with approximately $1,000 \mathrm{ppb}$ carbon tetrachloride. The cost information was obtained from R.S. Skeen, S.P. Luttrell, B.S. Hooker, and J.N. Petersen, "In situ bioremediation of Hanford groundwater," Remediation, Summer 1993, pp 353-367.

\section{Time}

a. When will the technology be available?

The technology will be available for use, once demonstrated, in September of 1994.

b. What is the speed or rate of the technology?

Present estimates indicate that this technology should remediate the Hanford test site in half the time required by conventional pump-and-treat methods. The actual rate of cleanup will be determined in the field test.

For the test case evaluated as part of life cycle cost analysis, bioremediation was twice as fast at cleaning up the groundwater as pump-and-treat. These estimates were based on permeable Hanford soils. The difference between cleanup rate for pump-and-treat and bioremediation is expected to be greater for sites with less permeable soils. This information was obtained from R.S. Skeen. S.P. Luttrell. B.S. Hooker, and J.N. Petersen, "In situ bioremediation of Hanford groundwater," Remediation. Summer 1993, pp 353-367. 
(11) c. What is the total time required for setup and removal and the total time for the technology to achieve its objectives?

For the test case evaluated as part of life cycie cost analysis, the treatment zone required approximately 260 days to remediate. Depending on the size of the site, and specific operational systems employed for the site specific contamination problem, the cleanup time could vary significantly. Based on the test case described in R.S. Skeen, S.P. Luttrell, B. S. Hooker, and J.N. Petersen, "In situ bioremediation of Hanford groundwater," article submitted to Remediation, cleanup could be accomplished in less than a year.

\section{Environmental Safety and Health: Worker Safety}

a. Will workers be exposed to hazardous materials or other hazards?

Workers will be exposed to very innocuous chemicals such as acetate (vinegar) and sodium nitrate.

b. What are the physical requirements for workers?

No strenuous physical activities are required to implement the technology.

c. How many people are required to operate the technology?

During bioremediation operations, one or two operators will probably be required.

\section{Environmental Safety and Health: Public Health and Safety}

a. Is there a history of accidents with this technology?

Because this is a low-pressure, low-temperature process and no heavy equipment is used. major injury or life threatening accidents are very unlikely.

b. Does this technology produce routine releases of contaminants?

No routine releases will occur from the process. A gentle venting of carbon dioxide and nitrogen gas can be expected if the site application is quite shallow. Infrequent releases due to accidents could occur from the above-ground processing equipment. Vinegar and/or nitrate solutions could be spilled. However, these materials have no significant health impacts. This technology is inherently safer than the baseline pump-and-treat methods because it does not require contaminated water to be brought to the surface. thus reducing the potential for public and worker exposure. In addition, public health and safety risks are further reduced because this technology does not require offsite shipment of contaminated materials. The baseline technology for treating carbon tetrachloride, activated carbon, requires offsite shipment for carbon regeneration. 
(13) c. Are there potential impacts from transportation of equipment, samples, waste, or other materials associated with the technology?

This technology does not require offsite shipment of contaminated materials. The baseline technology for treating carbon tetrachloride, activated carbon, must be shipped offsite for carbon regeneration.

\section{Environmental Impacts}

a. Will this technology have an impact on the ecology of the area (for example, wildlife, vegetation, air, water, soil, or people)?

The technology should greatly reduce the negative impacts of the contamination, and add no additional hazardous materials or byproducts to the environment. The only byproduct of significance is excess biomass produced within the aquifer. Changes in aquifer permeability will need to be evaluated to ensure that they are not detrimental. Fermentation of the excess biomass over time may slightly impact the natural water quality, but the water quality issue can be resolved with appropriate process design.

b. Does the technology have aesthetic impacts (for example, visual impacts, noise)?

The natural surface environment will be unchanged, except for the addition of well heads and temporary process equipment.

c. What natural resources are used in the technology's development, manufacture, or operation?

The process uses natural vinegar and possibly sodium nitrate.

d. What are the technology's energy requirements?

The process consumes very little energy. The equipment that requires the most energy are the pumps used to circulate groundwater and inject nutrients.

\section{Socio-Political Interests: Public Perception}

a. What is the reputation of the technology's developer or user?

EPA is a strong proponent of bioremediation, and in general the technology has a good reputation. Other proponents include consulting firms and other federal agencies, as well as private industries (such as chemical and oil companies) with contamination problems. If the primary proponent was industry, public confidence might be lower. However. strong endorsement from EPA adds credibility to the technology.

b. Is the technology familiar to the public and easy to understand?

The public may be familiar with some applications of the technology, such as bioremediation of oil spills. The technology is relatively easy to understand. 


\section{Socio-Political Interests: Tribal Right /Future Land Use}

a. Will the technology affect future unrestricted use of land and water?

In situ bioremediation will enhance future land use by minimizing impacts to the surface environment. The goal of the technology is to restore the aquifer to levels that will allow unrestricted use.

\section{Socio-Economic Interests}

a. What are the potential economic impacts of this technology? (For example, what are the effects on the economic base of the community? Are there infrastructure requirements?)

The major benefit of the technology is lower cost of cleanup, which should have a positive impact by reducing the budget requirements for restoration activities.

b. Will the technology affiect labor force demands?

Operation of the system will require a limited labor force.

\section{Regulatory Objectives}

a. Is the technology compatible with cleanup milestones?

If the demonstration is successful, the technology should be available in late 1994 or early 1995, soon enough to meet expected milestones for the installation of systems to treat VOCs in groundwater at most DOE sites (1996-99). At Hanford this technology might have to be phased in to replace or supplement pump and treat systems which are installed earlier. This system's ability to achieve cleanup milestones compared with the baseline (pump and treat) will be determined by the demonstration.

b. Are regulators familiar with this or a similar technology ? What is the technology's regulatory track record?

The track record is limited but improving. Historically, the availability and reliability of bioremediation for trealing groundwater has been perceived as uncertain and unpredictable. Recently EPA has moved forward with a significant investment in tracking case studies, documenting success, and disseminating information.

c. Does the technology comply with applicable regulations?

This system is expected to be compatible with regulatory requirements, although a number of regulatory issues need to be addressed through discussions with regulators before and during the demonstration. 


\section{Industrial Partnerships}

a. What is the name of the industrial partner?

No partnerships have been established to date. Discussions with several companies are underway.

b. What is the rationale for this partnership?

Industrial partnerships would ensure successful transfer of the technology to industry and the environmental consulting firms. Collaborations are being pursued both for industrial companies desiring the technology for their own.clean-up actions and for industrial consulting or service companies to provide the service to other clients for site cleanup. Because the contaminants and organisms are so site-specific for this technology, a capability, not a technology is the marketable product. Therefore, the possibility of developing intellectual property for Pacific Northwest Laboratory is difficult. Sectors of the economy with potential interest in developing bioremediation products and services to clean up the many thousands of VOC- and nitrate-contaminated sites in the U.S. include Allied Signal, DuPont, Kodak, Exxon, GE, Occidental Petroleum, Sybron Chemicals, Westinghouse Electric and biotechnology companies such as Celgene, ECOVA, Envirogen, Genencor, and several companies that sell microbial inocula, the substance containing cultured bacteria. Most of the environmental engineering firms are interested in subcontracting with DOE to provide clean-up services.

c. What is the contract mechanism?

No contracts exist.

d. Are there other potential partners?

Allied Signal, DuPont, Kodak, Exxon, GE, Occidental Petroleum, Sybron Chemicals, Westinghouse Electric Celgene, ECOVA, Envirogen, and Genencor.

e. Are there potential international partners?

Intermational partnerships are not being pursued at this time; however, a number of the potential companies listed above are involved in international business.

\section{Intellectual Property}

a. Who owns the patent for this technology?

No single patent exists for the technology. Elements of the technology are the intellectual property of various organizations. Stanford has applied for a patent on the mixing well designs. Rice University has the rights to the design simulation software. Treatability study equipment was developed by Pacific Northwest Laboratory and an invention disclosure has been filed. Specific enhancements to the technology have also been described in invention disclosures. 
(20) b. Are there other patent owners?

Owners of various patents that apply to this technology include Stanford University, Rice University, and possibly IEG, owners of the German UVB technology for vacuum stripping of VOCs in groundwater.

c. Is there a patent number for this technology?

The patent numbers are not known.

\section{Cost Sharing}

a. What is the background of this technology? (Where did the idea come from? Who else is doing similar work? What have the results been to date? What is the most significant competitor to this technology?)

Costs for development are not being shared at this time. The technology development has relied upon previously developed tools, such as the EPA-sponsored work with mixing systems and Rice University work with three-dimensional simulations. Efforts are underway to establish closer relationships with industry and cost sharing may become feasible. The Department of Energy is helping to defray part of the costs of the demonstration by installing a vapor stripping test site down grade from the bioremediation site. The bioremediation test will therefore not need to install downgradient monitoring or recovery wells, which will save money and resources.

The bioremediation industry can trace its roots to waste water treatment, waste management, oil field microbiology, the mining industry, biotechnology and genetic engineering. Bioremediation have been conducted for the past 15 years and is being developed and marketed by bio-engineering firms.

The current understanding of the microbial degradation of carbon tetrachloride is limited, particularly in comparison to other chlorinated aliphatic compounds such as trichloroethylene (TCE) that are common groundwater contaminants. However, progress has been made in recent years in identifying microorganisms and understanding mechanisms of carbon tetrachloride biodegradation. Carbon tetrachloride biodegradation has been demonstrated with a number of different bacteria. The conditions that favor biodegradation of carbon tetrachloride are predominantly anaerobic. Biodegradation of carbon tetrachloride under denitrifying conditions is of particular interest because both nitrates and carbon tetrachloride exist in the unconfined aquifer on the Hanford site.

Efforts to evaluate the potential for bioremediation of Hanford's carbon tetrachloridecontaminated groundwater began in 1987. Based on the results of early laboratory studies, and limited pilot testing, a program was established to evaluate in situ bioremediation was feasible through a field demonstration. Feasibility was carefully evaluated during the field demonstration with parallel laboratory-, intermediate-, and field-scale activities. The primary activities included 1) test site hydrological, geochemical, and microbiological characterization, 2) remediation design through laboratory, flow-cell, and three-dimensional modeling studies, 3) installation and verification of the well network and process and monitoring equipment, 4) demonstration testing and data analysis, and 5) post-demonstration site characterization. A location within the 200 West Area at Hanford was selected in fiscal year (FY) 1990 for development of the bioremediation test site. Characterization and preparation of the test 
(21) site began in FY 1991 as part of the Department of Energy's VOC-Arid Integrated Demonstration. Two of the five primary test wells have been installed, and the third test weil is being designed for installation this fiscal year. As part of the effort to address inadequate mixing, innovative mixing well designs are being considered for the remaining three wells. In collaboration with EPA's Western Region Hazardous Substance Research Center, Pacific Northwest Laboratory is designing and testing innovative single-well recirculation systems at the Hanford test site. 


\section{Technology Information Profile: Resonant Sonic Drilling}

Common Name of Technology: Sonic Drilling

Principal Investigator: G.W. McLellan, (509) 376-2260

Westinghouse Hanford Company

Technology Category: Drilling Technologies

Developed by: Pacific Northwest Laboratory, Water Development Corporation, and Westinghouse Hanford Company through a Cooperative Research and Development Agreement (CRADA)

\section{Integrated Demonstration Need for the Technology}

Advanced drilling technologies are needed to reduce costs, minimize waste from drilling. and contain drill cuttings and effluents while drilling. Resonant sonic drilling is a promising method for several drilling applications including boring holes for characterization (to determine the location and extent of contamination); drilling groundwater monitoring, vapor. and water extraction wells; installing barrier holes; and obtaining continuous core samples (vertical to horizontal).

\section{Technology Objectives}

a. What is the objective of this technology (for example, will this technology destroy volatile organic compounds [VOCs] in groundwater)?

The objectives of enhancing the sonic drilling technology are to

- obtain representative subsurface samples

- minimize secondary waste

- reduce costs for drilling by increasing productivity.

Sonic drilling will also minimize worker exposure to drilling hazards and contaminarion. Sonic drilling is also used to place instruments, sensors, and other devices in the subsurface for characterization, remediation, and monitoring.

b. What is the technology that is currently used for this application (baseline technology)?

The technology that is currently used at Hanford is cable tool drilling.

\section{Technology Application}

a. Where is the technology applied (in situ [in place] or ex situ [above ground])?

Sonic drilling is used in situ. 
(3) b. What media (soil, groundwater, air) is the technology used in?

Sonic drilling is used in soil and groundwater.

c. What contaminants does the technology target?

Although drilling is not a treatment technology, it is typically used to reach soil and groundwater contaminated with chemical and radioactive waste.

\section{Process Description}

Resonant sonic drilling has three major components: a drill rig with a sonic head. a drill pipe. and a drill bit. The drill head uses counter-rotating weights to generate energy, which causes the drill pipe to vibrate elastically along its entire length. The drill head operates at frequencies close to the natural frequency of the steel drill pipe (up to 150 cycles per second). In the resonant condition, forces up to $200,000 \mathrm{lbs}$ are efficiently transmitted to the drill bit face to create a very effective cutting action. The resonant energy causes sands, gravels. cobbles and even clays to relax into the adjacent formation just enough to permit the drill pipe to advance freely.

As the drill pipe moves through the ground during drilling, the walls of the steel pipe expand and contract helping to reduce any dampening of the vibrations caused by ground swelling. The drill bit can be designed to either push the soils into the borehole wall or modified to allow a continuous core to enter the steel pipe of the drill. Core samples can be continuously retrieved by using either a wireline latch or small inner rod retrieval assembly. A wireline latch is used to connect the core barrel (which runs inside the drill pipe) to the drill pipe. As the drill pipe is pushed into the ground, the core barrel fills with soil. Once the core barrel is full (at approximately 10 feet of drilling), the barrel is unlatched and removed from the drill pipe on a cable (wireline). The drill pipe is left in the ground at the depth to which the well was cored to support the borehole. After the core barrel is emptied at the surface. it is returned to the bottom of the borehole and relatched in the drill pipe. No drilling fluid is required with the sonic method, so the only byproduct from drilling is the core sample.

a. What is the input to the technology (energy, feedstream for treatment technulugies)?

A diesel engine typically powers the drive pump(s).

\section{b. What is the output of the technology?}

The output consists of high-quality core samples or data from downhole probes and sensors. Unused core samples are the only secondary byproduct from drilling beciuse the resonant energy causes sands, gravels, cobbles and even clays to relax into the adjacent formation just enough to permit the drill pipe to advance freely. 


\section{Scope of Project (feasibility study, treatability, bench, pilot, field demonstration)}

The scope of the current sonic drilling demonstration for the VOC-Arid Integrated Demonstration (ID) is laboratory development and field testing. Laboratory development has been needed to improve the sonic drill pipe, including failure analysis and fatigue testing. Also, new thread designs and different grades of pipe are being developed to withstand the forces on the drill pipe by the sonic drill.

\section{Summary of Technology Advantages (compared with the baseline technology: Is it faster, better, cheaper, safer?)}

The key advantages of the sonic drilling method are that

- the drilling rate is faster

- it contains all drill cuttings

- it minimizes secondary drilling waste and reduces the amount of liquid contained in those wastes

- it improves sample quality in formations where the baseline method cannot retrieve highquality samples (for example, caliche or boulders)

- it increases safety because workers are exposed to fewer physical hazards and less contamination.

Additionally, sonic drilling decreases contamination of supplemental drilling components (which occurs with systems that require a circulation media), and maintains excellent contamination control at the collar of the borehole. It also drills at any angle, from horizontal to vertical.

\section{Limitations of Technology (compared with the baseline technology)}

While sonic drilling is an improvement on the baseline in such areas as faster drilling rates, lower costs, and smaller quantities of secondary waste, downtime from equipment failures. both in the drill head and drill pipe, needs to be minimized. Decreasing downtime rates to levels consistent with other drilling methods will significantly reduce costs compared with the baseline.

\section{Major Technical Challenges for the Technology}

The major challenge is to improve the reliability of the drill pipe for resonant sonic drilling. A resonance monitoring system will be valuable in determining the threshold energy levels for the drill pipe design. In addition, an accurate measurement system to determine the thermal effects of the bit on the core sample is needed to develop bits which will maintain the integrity of the contaminants being characterized (for example, to avoid volatilizing organics), while maintaining acceptable penetration rates. Directional drilling applications are also being pursued. 


\section{Technical Effectiveness: Performance Criteria}

a. What contamination will remain in the environment after the technology is applied? (Will the mobility of the remaining contamination be reduced? Will the volume be reduced? Will the contaminant be less toxic? This criterion applies primarily to treatment technologies.)

Not applicable to sonic drilling.

b. What process waste (secondary waste) does the technology produce? (Is the secondary waste mobile? What is its volume? What hazards are associated with the secondary waste? Can it be recycled?)

Drilling generally produces only the cored sample. In a typical well ( 8 inches in diameter), sonic drilling produces approximately one 55-gallon drum of cuttings for every 60 feet drilled, which is significantly less than the amount of cuttings produced from cable tool drilling.

c. Is treatment or storage needed and available for the secondary waste?

The treatment and handling of secondary waste (core sample) depends on the waste type: radiological, chemical, or mixed. However, management systems do exist for these wastes to be stored or treated.

d. Is decontamination or decommissioning of equipment required?

Core tubes/samplers will need to be decontaminated after each sample to prevent crosscontamination between samples. Drill bits. core barrels, and drill rods are normally decontaminated between each borehole to prevent cross-contamination between boreholes.

e. Is disposal of secondary waste needed and available?

Small quantities of secondary waste will need to be disposed of, depending on the contamination present.

f. How practical is the technology? Does it foreclose future cleanup options? (Applies primarily to treatment technologies)

Not applicable to sonic drilling.

g. How reliable is the technology?

Currently sonic drilling's reliability is considered marginal; however, recent enhancements in industry applications will increase the reliability to an acceptable level. The goal of the current project is to reduce overall downtime from equipment failure and drilling related problems to less than $10 \%$.

h. If the technology fails, can the effects of the failure be controlled easily and quickly?

Not applicable (sonic drilling is not a treatment technology). 
(9) i. How easy is the technology to use?

The entire system is hydraulically controlled and is fairly easy to operate. However. the controls are much more complicated than a cable tool drill rig (the baseline technology) Operators of both will require years of experience to become proficient. In addition. the sonic drill operator must be able to listen to and evaluate the noise the drill pipe is making to optimize the drilling rate. Part of the CRADA development effort is to automate the drilling parameters to simplify use of the drill rig and possibly help to reduce the occurrence of broken drill pipe.

j. What infrastructure (buildings, power sources, personnel) is needed to support the technology?

Typically two people are required to operate the drill, an operator and an assistant. A gas or diesel engine is used to power the sonic drill rig.

k. How versatile is the technology? Can it be applied to other types of contamination, in other media, or at other locations?

The sonic method can be used in various soil types to obtain continuous, high-quality core samples; it can also be used for vertical, horizontal, and angle drilling.

1. Is the technology compatible with other elements of the remediation system?

Yes, sonic drilling is compatible with other elements of a remediation system. The boreholes drilled by the sonic rig can be used for any application that would normally use more conventional drilling methods. Also, unlike the cable tool rig, the sonic rig can drill at an angle (up to 15 degrees from horizontal). This will be useful for remediation work under tanks, cribs, and any other areas inaccessible by vertical drilling methods.

m. Can the technology be procured "off-the-shelf'?

The sonic system currently in development is not an off-the-shelf system; however. the method may be available from a manufacturer by mid- 1994 .

n. Is the technology equipment easy to maintain?

Yes, the system is easy to maintain. However, because of its extensive hydraulic system. the sonic drilling rig does require approximately two times the preventive maintenance of the cable tool rig.

o. What safety measures are required to protect workers and the public?

Frequent safety meetings and proper protocols are the key to safe operation of the sonic drilling operation. While all drilling methods can be hazardous, no accidents have occurred on the sonic rig during 8 months of operation. The public is not expected to be exposed to hazards from sonic drilling.

p. Does the technology work as intended?

During the sonic feasibility test. even a 20 -year-old rig functioned as intended. although there was a high equipment failure rate. 


\section{Cost}

a. What is the start-up cost of the technology (including development costs, procurement and construction, permitting, and other costs necessary to begin operation)?

The costs of obtaining a high quality used rig are approximately $\$ 300,000$. The cost of drill strings (the entire length of drill pipe, drill rod, or drill casing that hangs in the borehole) are not known because further development of the strings is required.

b. What are the operations and maintenance costs of the technology?

Operations and maintenance costs are expected to be slightly higher than cable tool (approximately 20\%) but the increase in productivity will more than offset the increased maintenance costs.

In preliminary tests of sonic drilling at the Hanford site, costs for 11 holes were approximately $15 \%$ to $20 \%$ less than the baseline technology, even though downtime from equipment failures was over $45 \%$. With refinement and development of products/components, such as the resonance monitoring system, downtime is expected to be reduced to less than $10 \%$, which will substantially reduce direct drilling costs and times.

c. What are the life cycle costs of the technology (including facility capital cost: startup, operation, and maintenance; decommissioning, regulatory, or institutional oversight; and future liability)?

Life cycle costs are not known at this time.

\section{Time}

a. When will the technology be available?

Sonic drilling is currently available; however, the needed improvements noted above are not completed. Full implementation of other capabilities for sonic drilling are expected to be as follows:

- Vertical drilling (wider use on various projects)-12 to 24 months

- Diagonal and vertical use (medium and high level waste sites)-24 to 42 months.

The following assessments represent best estimates on various application timelines:

- Vertical and Diagonal Drilling

- All chemical and low-level radioactive sites-1 year

- Medium- to high-level radioactive sites-2 to 3 years

- Horizontal Drilling (see note)

- Feasibility testing-1 year

- All chemical and low-level radioactive sites-2 to 3 years

- Medium- to high-level radioactive sites-3 to 5 years. 
(11a) Note: Sonic currently is viewed as a possible casing advancement technique for directionally drilled holes under single-shell tank farms. Depending on the evolution of the method, it may become the sole method for installing these or similar holes for other projects.

b. What is the speed or rate of the technology?

Currently, the sonic method drills holes at double the rate of cable tool drilling, but equipment failure reduces the effective rate.

c. What is the total time required for setup and removal and the total time for the technology to achieve its objectives?

Not applicable.

\section{Environmental Safety and Health: Worker Safety}

a. Will workers be exposed to hazardous materials or other hazards?

The sonic method has no circulation system and controls waste at the collar of the hole: therefore, it minimizes personnel exposure to hazardous substances. Heavy wrenches. which can injure workers, are not required, and the sonic method has fewer moving parts that could cause injury.

b. What are the physical requirements for workers?

The average noise level is 85 to $90 \mathrm{dBa}$ (decibels adjusted), so hearing protection is required. Standard safety gear is usually adequate for workers. Automated pipe-lifting equipment reduces physical effort required of operators.

c. How many people are required to operate the technology?

Typically two people are required to operate the drill, an operator and an assistant. $A$ geologist is also employed at most Hanford drilling sites to log samples. In areas of medium- to high-contamination, a health physics technician and a site safety officer are needed to monitor contamination levels. In areas of high contamination, an additionil laborer is needed for contamination control and to decontaminate equipment.

\section{Environmental Safety and Health: Public Health and Safety}

a. Is there a history of accidents with this technology?

The sonic drill has operated 8 months without an accident. There is no reasonable potential for accidents or other hazards to the public from sonic drilling.

b. Does this technology produce routine releases of contaminants?

VOC vapor may be released infrequently. However, if drilling is done in hazardous areas, use of proper containment techniques can eliminate releases of hazardous substances. 
(13) c. Are there potential impacts from transportation of equipment, samples, waste. or other materials associated with the technology?

This technology is easily and safely transported on highways, dirt roads, and off-road.

\section{Environmental Impacts}

a. Will this technology have an impact on the ecology of the area (for example, wildlife, vegetation, air, water, soil, or people)?

Sonic drilling produces some noise ( 85 to $90 \mathrm{dBa}$ ) and vibrates the soil. As with all drilling technologies, an area must be cleared for a drill pad. No significant impacts are expected.

b. Does the technology have aesthetic impacts (for example, visual impacts, noise)?

Sonic drilling is about the same size and height as other drill rigs; it is quieter.

c. What natural resources are used in the technology's development, manufacture, or operation?

No natural resources are used for sonic drilling other than those required to manufacture the equipment.

d. What are the technology's energy requirements?

A gas or diesel engine powers the sonic drill rig.

\section{Socio-Political Interests: Public Perception}

a. What is the reputation of the technology's developer or user?

The reputation of the technology's developer is not known.

b. Is the technology familiar to the public and easy to understand?

Recent publications and near-term/long-duration tests at Hanford should increase the public's familiarity with this technology. The technology is easily explained.

\section{Socio-Political Interests: Tribal Right /Future Land Use}

a. Will the technology affect future unrestricted use of land and water?

No. The area where the drill rig is used must be graded; however, grading doesn't preclude revegetation. 


\section{Socio-Economic Interests}

a. What are the potential economic impacts of this technology? (For example, what are the effects on the economic base of the community? Are there infrastructure requirements?)

Sonic drilling will have minimal economic impact.

b. Will the technology affect labor force demands?

This technology typically will function with private industry support exclusively. Operators will be skilled and trained specifically for this technology.

\section{Regulatory Objectives}

a. Is the technology compatible with cleanup milestones?

Yes. If downtime can be reduced to levels comparable to those of other drilling methods, sonic drilling should help users meet cleanup milestones because its drilling rate is faster than standard methods, such as cable tool.

b. Are regulators familiar with this or a similar technology? What is the technology's regulatory track record?

Because sonic drilling has not yet been routinely used in cleanup applications, regulators are not very familiar with this technology.

c. Does the technology comply with applicable regulations?

Sonic drilling met applicable well construction and maintenance requirements during feasibility tests in FY 1992. Because no circulation medium is required. the need to manage drilling fluid as a solid waste (potentially a hazardous waste) is eliminated, an advantage for regulatory compliance.

\section{Industrial Partnerships}

a. What is the name of the industrial partner?

Water Development Corporation is the industrial partner.

b. What is the rationale for this partnership?

Because the nature of the resonance impacts to drill pipe are unknown, working with an industry lead contractor for this system will help solve equipment reliability issues.

c. What is the contract mechanism?

The contract mechanism is a CRADA. 
(19) d. Are there other potential partners?

No.

e. Are there potential international partners?

No.

\section{Intellectual Property}

a. Who owns the patent for this technology?

Water Development Corporation hold all the patents for the resonant drilling system.

b. Are there other patent owners?

No.

c. Is there a patent number for this technology?

There is not a single patent number for this technology.

\section{Cost Sharing}

a. What is the background of this technology? (Where did the idea come from? Who else is doing similar work? What have the results been to date? What is the most significant competitor to this technology?)

Sonic drilling was developed in the early 1960s by Albert Bodine and used in the geotechnical and mining industry, specifically for placer (gold) exploration. Approximately 20 sonic heads were manufactured by Hawker Siddeley (HS) in Canada by 1985 . In 1986, HS left the business and sold the remaining sonic equipment to industry contractors. Four contractors (three U.S. based and one from Canada) now use the sonic method. Water Development Corporation holds the patents, documentation files. and sonic drilling equipment from the resonant drilling system developed by $\mathrm{Al}$ Bodine. 
IN-WELL VAPOR STRIPPING 


\section{VOC-Arid Integrated Demonstration}

\section{Fact Sheet: In-Well Volatile Organic Compound Removal System Using Air Sparging and Reinfiltration}

\section{Category: Groundwater remediation}

Need: Many DOE sites have aquifers where groundwater is contaminated with VOCs. Carbon tetrachloride. chloroform, and trichloroethylene are found at the Hanford site. In situ technologies are needed because it is expensive to bring the water to the surface for treatment. Furthermore, if the water contains tritium. as it does at the Hanford site, surface storage and disposal of the tritiated water are a major problem. Using the In-Well VOC Removal System, the VOCs are removed from the aquifer without removing the contaminated water. The system provides a way to convert groundwater contamination into a vapor stream which can be easily treated at the surface.

Description: The In-Well VOC Removal System volatilizes the VOCs contained in the groundwater and removes them as a vapor. The vapor is retrieved using vacuum extraction and treated above ground by adsorption onto granular activated carbon (GAC).

The system consists of a well within a well. The inner well extends from the ground surface into the saturated zone and is screened in the zone of contamination. The outer well extends from the ground surface through the unsaturated zone and may end above the water table. This outer well may also be screened in the unsaturated zone so it can be used for soil vapor extraction.

A gas injection line is placed in the inner well and releases bubbles in the well below the zone of contamination. The bubbles rise in the well and collect VOCs, which are transferred from the liquid phase to the gas bubbles. The bubbles and water rise within the well until they hit a packer (a device used to prevent fluids from moving past it) that is placed in the inner well above the elevation of the water table. The inner well is screened just below the packer, allowing the water and bubble mixture to escape into the space between the inner and outer well (annular space). The water falls down the annular space and is returned to the water table. The gas bubbles pop and are vacuumed off through a vacuum line extending from the ground surface into the annular space. In this way the VOC-enriched vapor is extracted, and the partially cleaned water is returned to the aquifer. The system recirculates the groundwater through air-lift pumping.

In essence, the In-Well VOC Removal System converts groundwater contamination into is vapor that is vacuum-extracted and treated. At the same time, air-lift pumping circulates the groundwater, which becomes cleaner and cleaner with each pass through the in-well air stripper.

Advantages: The In Situ VOC Removal System can continuously remove VOC.s fiom groundwater without pumping the water to the surface. It avoids the need to handle contaminated water above the ground and to dispose of or store partially treated water. There is no need for an above-ground air-stripping tower (to remove the contaminants from water $1 \mathrm{~s}$ vapor) or storage tanks to contain the treatted water that is free of VOCs. Compared with the baseline groundwater extraction method. in which reinjection of treated water is permitted. the In-Well VOC Removal system would not require drilling expensive injection wells. 
This technology can also be used to recirculate chemicals used in groundwater remediation techniques, such as surfactants and catalysts. Finally, the method also has the advantage that a single well can be used for extracting soil vapors and for groundwater remediation. The baseline technology would require separate pump-and-treat wells and soil vapor extraction wells. The In-Well VOC Removal System is cheaper, safer, and as fast as pump-and-treat techniques and soil vapor extraction.
Challenges: The method itself involves no moving parts beneath the ground surface: however, careful packer and well designs will be required to successfully divert the groundwater from the well back into the unsaturated zone and to the water table. There are also potential challenges in managing the chemical changes in the groundwater, soil, and aquifer (such as chemical precipitation or oxidation) that may accompany use of this system. Monitoring the state of the groundwater system at a distance from the VOC-removal well is expensive at the Hanford site, and presents a challenge for both this technology and the baseline. 


\section{Air Sparging (In-Situ VOC Removal System)}

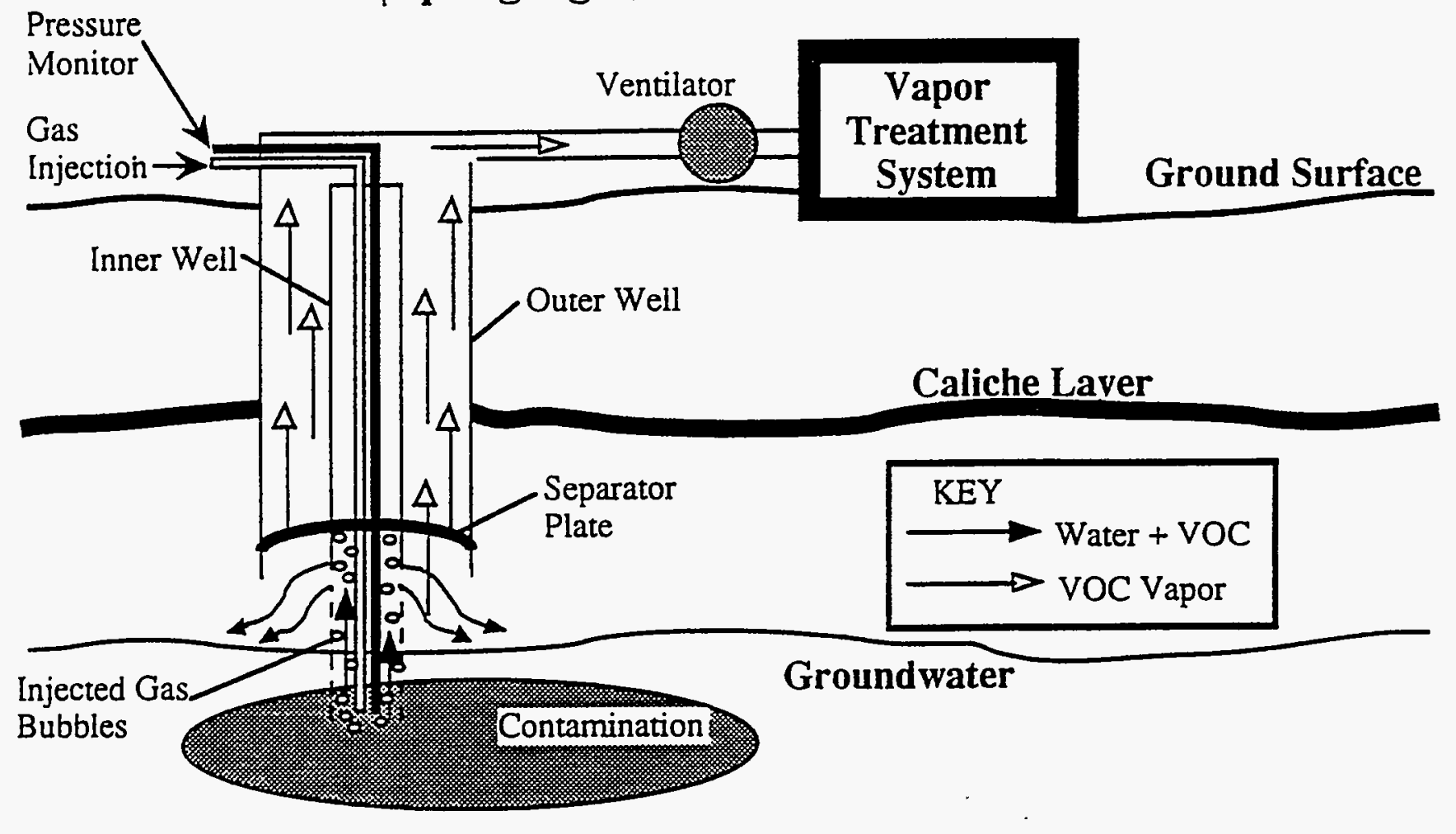




\section{Technology Information Profile: In-Well Volatile Organic Compound Removal System Using Air Sparging and Reinfiltration}

Common Name of Technology: In-Well Air Sparging

Principal Investigator: Steven M. Gorelick, (415) 725-2950

Stanford University

Technology Category: Groundwater remediation

Developed by: Stanford University

\section{Integrated Demonstration Need for the Technology}

Many DOE sites have aquifers where groundwater is contaminated with VOCs. Carbon tetrachloride, chloroform, and trichloroethylene are found at the Hanford site. In situ technologies are needed because it is expensive to bring the water to the surface for treatment. Furthermore, if the water contains tritium, as it does at the Hanford site, surface storage and disposal of the tritiated water are a major problem. Using the In-Well VOC Removal System. the VOCs are removed from the aquifer without removing the contaminated water. The system provides a way to convert groundwater contamination into a vapor stream which can be easily treated at the surface.

\section{Technology Objectives}

a. What is the objective of this technology (for example, will this technology destroy volatile organic compounds [VOCs] in groundwater)?

The objective of this demonstration of this system is primarily to show the method's effectiveness and efficiency in removing carbon tetrachloride from the groundwater. The system will first be demonstrated for groundwater remediation, but a combined soil vapor extraction and groundwater remediation system will also be demonstrated. The combined system can remove VOCs contained in both the unsaturated zone (soil) and the saturated zone (aquifer).

b. What is the technology that is currently used for this application (baseline technology)?

Currently, groundwater is pumped from the ground and treated at the surface.

\section{Technology Application}

a. Where is the technology applied (in situ [in place] or ex situ [above ground[)?

The technology is applied in situ. 
(3) b. What media (soil, groundwater, air) is the technology used in?

The technology is used for groundwater and vapor.

c. What contaminants does the technology target?

Air sparging targets carbon tetrachloride, chloroform (Hanford), or any volatile organic compound (VOC) amenable to air stripping.

\section{Process Description}

The In-Well VOC Removal System volatilizes the VOCs contained in the groundwater and removes them as a vapor. The vapor is retrieved using vacuum extraction and treated above ground by adsorption onto granular activated carbon (GAC).

The system consists of a well within a well. The inner well extends from the ground surface into the saturated zone and is screened in the zone of contamination. The outer well extends from the ground surface through the unsaturated zone and may end above the water table. This outer well may also be screened in the unsaturated zone so it can be used for soil vapor extraction.

A gas injection line is placed in the inner well and releases bubbles in the well below the zone of contamination. The bubbles rise in the well and collect VOCs, which are transferred from the liquid phase to the gas bubbles. The bubbles and water rise within the well until they hit a packer (a device used to prevent fluids from moving past it) that is placed in the inner well above the elevation of the water table. The inner well is screened just below the packer . allowing the water and bubble mixture to escape into the space between the inner and outer well (annular space). The water falls down the annular space and is returned to the water table. The gas bubbles pop and are vacuumed off through a vacuum line extending from the ground surface into the annular space. In this way the VOC-enriched vapor is extracted, and the partially cleaned water is returned to the aquifer. The system recirculates the groundwater through air-lift pumping.

In essence, the In-Well VOC Removal System converts groundwater contamination into $\alpha$ vapor that is vacuum-extracted and treated. At the same time, air-lift pumping circulates the groundwater, which becomes cleaner and cleaner with each pass through the in-well dir stripper.

\section{a. What is the input to the technology (energy, feedstream for treatment technologies)?}

The only input to the system is gas, which is injected into the well. The injected gis will be air in the initial demonstration, and it will be recycied during the demonstration.

\section{b. What is the output of the technology?}

The only output of the system is the gas that is removed from the well: this gas contuns the VOCs removed from the groundwater and soil. After removal, this VOC vapor is adsorbed onto GAC. The VOCs then are typically incinerated or possibly recycled. and the GAC is regenerated and reused. The gas will also contain some moisture becaure it was in contact with the groundwater before it was removed. The gas stream will be monitored to determine the concentration of VOCs being removed and the gas tlow rate. 


\section{Scope of Project (feasibility study, treatability, bench, pilot, field demonstration)}

The project being conducted for the VOC-Arid Integrated Demonstration is a pilot-scale tield demonstration.

\section{Summary of Technology Advantages (compared with the baseline technology: Is it faster, better, cheaper,safer?)}

The In Situ VOC Removal System can continuously remove VOCs from groundwater without pumping the water to the surface. It avoids the need to handle contaminated water above the ground and to dispose of or store partially treated water. There is no need for an above-ground air-stripping tower (to remove the contaminants from water as vapor) or storage tanks to contain the treated water that is free of VOCs. Compared with the baseline groundwater extraction method, in which reinjection of treated water is permitted, the In-Well VOC Removal system would not require drilling expensive injection wells.

This technology can also be used to recirculate chemicals used in groundwater remediation techniques, such as surfactants and catalysts. Finally, the method also has the advantage that a single well can be used for extracting soil vapors and for groundwater remediation. The baseline technology would require separate pump-and-treat wells and soil vapor extraction wells. The In-Well VOC Removal System is cheaper, safer, and as fast as pump-and-treat techniques and soil vapor extraction.

\section{Limitations of Technology (Compared with the baseline technology)}

This technology, as it is currently envisioned, will not remove non-volatile compounds trom the groundwater, such as metals and radionuclides. If wells are not properly located, it is possible to spread the partially remediated (lower concentration) plume by recirculating partially treated water beyond the radius of the area in which the In Situ VOC Removal System will work.

Discharges of liquid to the unsaturated zone may also mobilize pockets of contaminant. Jdding to the total mass of contaminants in the aquifer, but these contaminants can be captured by the in situ VOC removal well.

\section{Major Technical Challenges for the Technology}

The method itself involves no moving parts beneath the ground surface; however. curetul packer and well designs will be required to successfully divert the groundwater from the " ell back into the unsaturated zone and to the water table. There are also potential challenges in managing the chemical changes in the groundwater, soil, and aquifer (such as chemical precipitation or oxidation) that may accompany use of this system. Monitoring the state if the groundwater system at a distance from the VOC-removal well is expensive at the Hantord vie. and presents a challenge for both this technology and the baseline. 


\section{Technical Effectiveness: Performance Criteria}

a. What contamination will remain after the technology is applied? (Will the mobility of the contamination be reduced? Will the volume be reduced? Will the contaminant be less toxic? This criterion applies primarily to treatment technologies.)

This method successively removes more and more VOCs from the groundwater, but it does not remove non-volatile compounds, such as metals or radionuclides. The technology may reduce the volume of the contaminant remaining after treatment faster than will pumping and treating the groundwater.

b. What process waste (secondary waste) does the technology produce? (Is the secondary waste mobile? What is its volume? What hazards are associated with the secondary waste? Can it be recycled?)

Like soil vapor extraction and groundwater extraction technologies, the process waste from this technology is the GAC containing the VOCs removed from the groundwater and small quantities condensed water vapor, which. at the Hanford demonstration site, will include tritium.

c. Are treatment and/or storage needed and available for the secondary waste?

This system will use GAC to treat off-gas, as does the soil vapor extraction system. although contaminants are likely to be at lower concentrations and volumes. Therefore, secondary waste treatment consists of removing the VOCs from GAC and destroying or possibiy recycling them and regenerating the GAC for reuse.

d. Is decontamination or decommissioning of equipment required?

The well used for this technology must be closed to prevent vertical migration.

e. Is disposal of secondary waste needed and available?

From 3 to 5 percent of VOCs are not removed from GAC during the regeneration process, so the GAC will ultimately have to be disposed of or treated (for example, by incineration) as a hazardous waste. Disposal facilities are available.

f. How practical is the technology? Does it foreclose future cleanup options? (Applies primarily to treatment technologies)

The use of this technology has no effects on future options.

g. How reliable is the technology?

Most of the equipment used in this technology is available off-the-shelf, so it has been proven reliable. The demonstration of this technology at Hanford will determine whether innovative system components are reliable.

h. If the technology fails, can the effects of the failure be controlled easily and quickly?

If the system fails, it can be shutdown automatically without significant consequences. 
(9) i. How easy is the technology to use?

The system is designed to run continuously with only routine maintenance. No complicated or difficult-to-operate components are used in the system, and the ease of controlling the process will be determined during the demonstration.

j. What infrastructure (buildings, power sources, personnel) is needed to support the technology?

No major facilities are needed for this technology. Power is needed to operate the pumps and compressors, and one to two people can operate the process.

k. How versatile is the technology? Can it be applied to other types of contamination, in other media, or at other locations?

The system can be used where VOCs contaminate groundwater under water table conditions. It cannot be used to remove non-volatile contaminants, such as metals or radionuclides.

I. Is the technology compatible with other elements of the remediation system?

The system can operate with a soil vapor extraction system at the same time, using the same well. It can also be used with some bioremediation applications and other physical and chemical treatment technologies.

m. Can the technology be procured "off-the-shelf"?

The components are commonplace and few in number. The method can be readily deployed. However, the expertise needed to use and monitor the technology is limited in the private sector. There is currently only one supplier of this technology.

n. Is the technology equipment easy to maintain?

Regular maintenance during the course of the demonstration will be necessary for the compressor and monitoring systems.

o. What safety measures are required to protect workers and the public?

Air monitoring for VOCs in the breathing zone is necessary.

p. Does the technology work as intended?

Related technologies have proven effective in shallow applications. This technology's effectiveness will be investigated during the demonstration at Hanford. 


\section{Cost}

a. What is the start-up cost of the technology (including development costs, procurement and construction, permitting, and other costs necessary to begin operation)?

Specific costs have not been determined. The primary cost components are the well installation, the compressor and packer, monitoring, and the GAC system. Planning for this demonstration has just begun, and the costs are currently being determined.

b. What are the operations and maintenance costs of the technology?

Planning for this demonstration has just begun; the costs are currently being determined.

c. What are the life cycle costs of the teclnnology (including facility capital cost: startup, operation, and maintenance; decommissioning, regulatory, or institutional oversight; and future liability)?

Planning for this demonstration has just begun; the costs are currently being determined.

\section{Time}

a. When will the technology be available?

This technology should be available in 1995 .

b. What is the speed or rate of the technology?

The speed or rate will be determined in the demonstration

c. What is the total time required for setup and removal and the total time for the technology to achieve its objectives?

The time required to achieve the objectives will be determined in the demonstration.

\section{Environmental Safety and Health: Worker Safety}

a. Will workers be exposed to hazardous materials and/or other hazards?

Exposure to VOCs is possible from duct leaks or venting from the well. Air monitoring is necessary.

b. What are the physical requirements for workers?

No strenuous activity is required for operation of the system.

c. How many people are required to operate the technology?

One to two people will be required to maintain and monitor the system. 


\section{Environmental Safety and Health: Public Health and Safety}

a. Is there a history of accidents with this technology?

Accidents that could result in the public's exposure to hazardous concentrations of VOCs are extremely unlikely.

b. Does this technology produce routine releases of contaminants?

Gases may be released.

c. Are there potential impacts from transportation of equipment, samples, waste. or other materials associated with the technology?

Precautions must be taken to prevent spills or releases during transportation of GAC canisters for offsite disposal or treatment and GAC regeneration.

\section{Environmental Impacts}

a. Will this technology have an impact on the ecology of the area (for example, wildlife, vegetation, air, water, soil, or people)?

No ecological impacts are anticipated.

b. Does the technology have aesthetic impacts (for example, visual impacts, noise)?

This system consists of small pumps, a compressor, and the GAC canisters, so it is not unattractive or noisy.

c. What natural resources are used in the technology's development, manufacture, or operation?

Only the natural resources used in manufacturing the equipment are required for this technology.

d. What are the technology's energy requirements?

Electricity is needed to run the compressor and monitoring equipment. When the exact system specifications are determined, the electrical requirements will be known.

\section{Socio-Political Interests: Public Perception}

a. What is the reputation of the technology's developer and/or user?

The current supplier's reputation has not been established. However, related technologies are gaining EPA acceptance, so EPA should become a proponent of the system.

b. Is the technology familiar to the public and/or easy to understand?

The technology is probably not familiar to the public, but it is fairly easy to understand. The system continuously removes VOCs from groundwater without pumping the water 
(15b)

to the surface. It operates like a giant fish-tank filtering system. Air is injected into a well, and air bubbles are created that collect dissolved VOCs and bring them to the surface for treatment. In addition, a recirculation zone is established in the aquifer. which becomes cleaner and cleaner over time.

\section{Socio-Political Interests: Tribal Right /Future Land Use}

\section{a. Will the technoiogy affect future unrestricted use of land and water?}

This technology will not affect land use. It is not known whether unrestricted use of the groundwater will be possible, but the goal of the technology is to achieve the groundwater quality standard for carbon tetrachloride of $5 \mathrm{ppb}$.

\section{Socio-Economic Interests}

a. What are the potential economic impacts of this technology? (For example, what are the effects on the economic base of the community? Are there infrastructure requirements?)

No significant economic impacts are anticipated.

b. Will the technology affect labor force demands?

No significant labor force demands are anticipated.

\section{Regulatory Objectives}

a. Is the technology compatible with cleanup milestones?

If the demonstration at Hanford is successful, the technology should be available in ume to meet expected milestones for installing systems to treat VOCs in groundwater at most DOE sites (1996-1999). At Hanford this technology might have to be phased in to replace or supplement pump and treat systems that were installed earlier. This system 's ability to achieve cleanup milestones compared with the baseline technology (groundwater extraction) will be determined by the demonstration.

b. Are regulators familiar with this or a similar technology? What is the technulugy's regulatory track record?

Because this technology is new, regulators are not very familiar with it. However. familiarity is growing because of the demonstration of similar technologies at uther vites in the U.S. and Europe.

\section{c. Does the technology comply with applicable regulations?}

This system is believed to be compatible with regulatory requirements, although there are a number of regulatory issues that need to be addressed in discussions with regulators before and during the demonstration. These issues include the injection of air and inert tracers. the in situ recirculation of groundwater. and the possibility of dispersion or redirection of the contaminant plume in the groundwater. 


\section{Industrial Partnerships}

a. What is the name of the industrial partner?

NoVOCs, Inc.

b. What is the rationale for this partnership?

The licensing of this technology has been transferred from Stanford to NoVOCs, Inc., which is in the process of seeking industrial alliances in the U.S. Large engineering and oil companies in the environmental remediation area have expressed serious interest in the technology. They are awaiting the results of this demonstration.

c. What is the contract mechanism?

The contract was executed through NoVocs Inc.

d. Are there other potential partners?

Several companies have expressed interest.

e. Are there potential international partners?

NoVOCs has arranged for licensing in Europe.

\section{Intellectual Property}

a. Who owns the patent for this technology?

Stanford University owns the patent.

b. Are there other patent owners?

No.

c. Is there a patent number for this technology?

The patent number is $5,180,503$.

\section{Cost Sharing}

a. What is the background of this technology? (Where did the idea come from? Who else is doing similar work? What have the results been to date? What is the most significant competitor to this technology?)

This technology was developed on an unfunded basis at Stanford University. It was developed by Professor Steven Gorelick (principal investigator) and a post-doctoral fellow in Gorelick's group, which works on aquifer remediation methods. Initial theoretical studies were conducted that showed the viability of the method for removing VOCs from groundwater. 


\section{MEMBRANE SEPARATION}




\section{VOC-Arid Integrated Demonstration}

\section{Fact Sheet: Volatile Organic Compound Offgas Membrane}

\section{Category: Above-Ground Separations}

Need: The VOC-Arid ID needs cost-effective methods to remove VOCs from gas streams that have been retrieved using techniques such as soil vacuum extraction. The cost of capturing VOCs by carbon adsorption (the technology that is currently used to treat gas streams) is about $\$ 5-15 / \mathrm{lb}$ of VOC. Present calculations indicate that the cost of treating emissions by membrane technology will be about $\$ 2-5 / \mathrm{lb}$ of VOC recovered. Also, the 1990 Clean Air Act Amendments requires that the direct discharge of VOCs be significantly reduced. To decrease the quantity of VOCs discharged to the atmosphere from cleanup activities, this technology or a similar technology needs to be developed.

The most common alternative to this technique is using granular activated carbon (GAC) to adsorb contaminants from gas. This technique generates secondary waste that must be disposed of, and the GAC must be regenerated regularly. The proposed membrane system would minimize the secondary waste and possibly provide a recyclable product.

Description: After VOCs are removed from the contaminated soil with vacuum extraction, they are treated in a high-pressure system that has been designed to treat feed streams containing dilute concentrations of VOCs. In this system. the feedstream is compressed and sent to a condenser where the liquid solvent is recovered. The stream from the condenser, which contains approximately $5000 \mathrm{ppm}$ of the VOCs. is then sent to the membrane module.

The membrane module is made up of spiral bound modules of thin film membranes separated by plastic mesh spacers: the membrane and the spacers are wound spirally around a central collection pipe. In the membrane module the stream is further concentrated to $25.000 \mathrm{ppm}$ VOC. The concentrated stream is then passed through the system again for a higher VOC recovery rate. The system is operated at the vacuum extraction site.

This technology will not replace the baseline GAC. It will, however, remove $95 \%$ of the VOC vapors before they are passed onto the GAC, so a smaller volume of VOC will be adsorbed on the GAC, thus reducing the overall cost for VOC removal.

Advantages: Membrane separation can remove $95 \%$ of the VOCs from the soil vent stream before they are introduced into the $\mathrm{GAC}$, significantly reducing the large amount of secondary waste otherwise generated. The membrane separation technology is less expensive than direct processing with GAC. The cost for capturing VOCs by carbon absorption is about $\$ 5-15 / \mathrm{lb}$. of VOC. Present calculations using membrane technology estimate costs of $\$ 5 / \mathrm{b}$ b. of VOC recovered.

Membrane separation also does not overheat from the heat of adsorption. unlike the G.AC process, because the desorption process in the membrane actually removes the heat generated from membrane adsorption. As a result. this system is ideal for high-concentration gis. streams (500 to $35,000 \mathrm{ppm}$ ).

Challenges: Two major challenges contront the membrane separation unit: 1) sizing the pilot plant to handle fluctuations in the $V O C$ flows from the well field and 2) fouling if ihe membrane with other constituents. 
High-Pressure Gas Membrane Separation

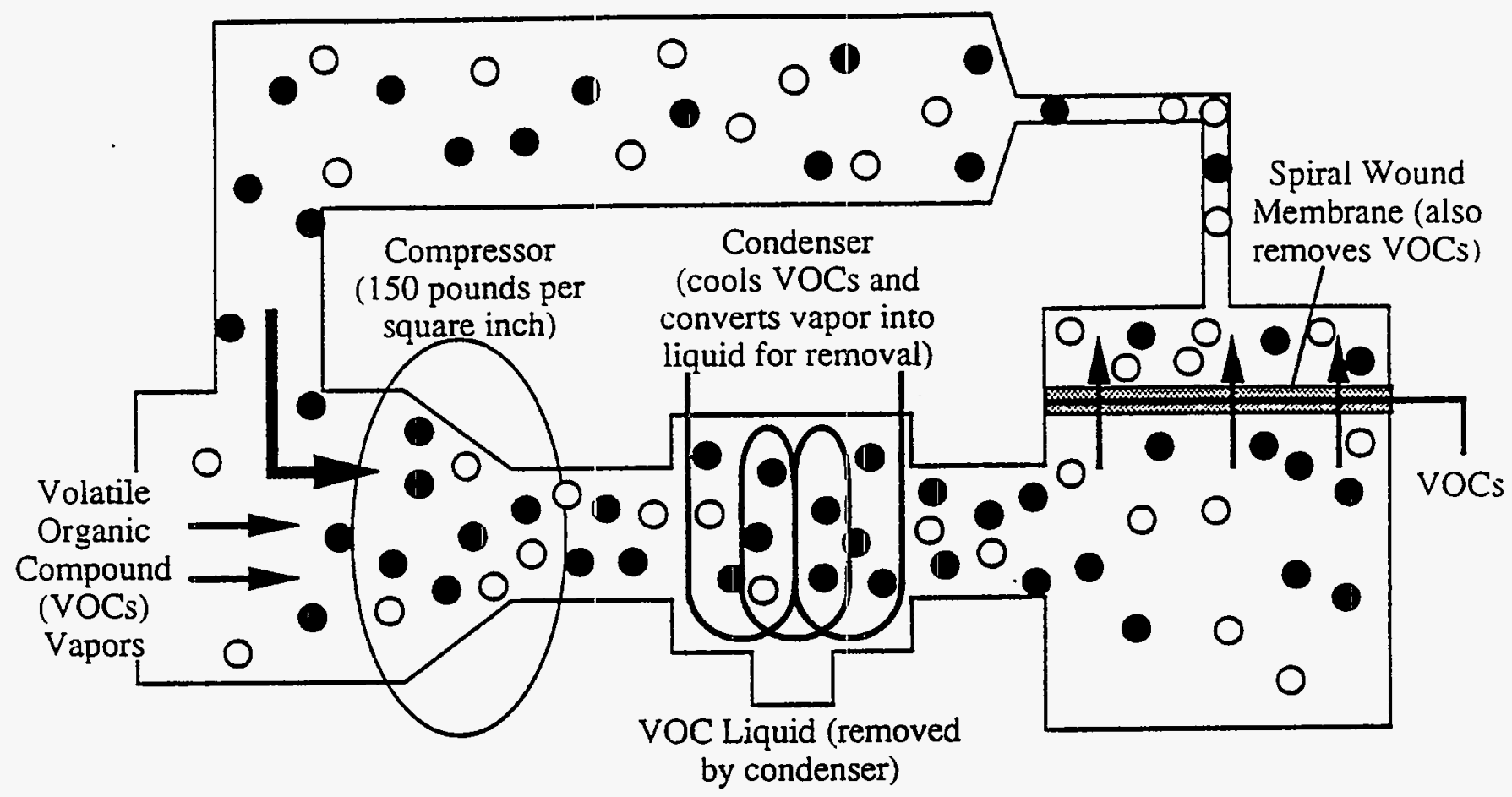


PASSIVE SOIL VAPOR EXTRACTION 


\title{
Technology Information Profile: Passive Soil Vapor Extraction
}

\author{
Full Name of Technology: Passive Soil Vapor Extraction (PSVE) \\ Using Wells and Boreholes
}

Common Names of Technology: Barometric Pumping, Borehole Flux, PSVE

Principal Investigators: Virginia J. Rohay, Westinghouse Hanford Company, 509-376-5507 (Technology coordinator) Wayne Downs, Idaho National Engineering Laboratory, 208-5260754 Joe Rossabi, Westinghouse Savannah River Company, 803-725-5220

Technology Category: Retrieval (removal from soil matrix)

Developed by: This technology is based on a natural phenomenon acting on subsurface soils. Subsurface soils are accessed through wells and boreholes, and the phenomenon is thereby enhanced. This remediation approach therefore, has not been invented. The natural phenomenon of air flow from the subsurface to the surface (and the reverse) due to atmospheric pressure change is being channeled and controlled during this demonstration. Some of the equipment used to enhance the natural air flow has been developed or improved by Principal Investigators.

\section{What is the need for the technology? (If this technology is part of a system of technologies, what is its role in the system and what is the need for the system?)}

This technology can be complementary to active soil vapor extraction. (Active soil vapor extraction uses non-renewable power to create a vacuum. That vacuum is applied to a subsurface soil area through a well or wells.) When the point of diminishing returns in removing a volatile contaminant is reached with active soil vapor extraction (because of mass transfer and energy cost limitations), there may still be significant contamination left in the ground. To remove the residual contamination efficiently, the removal process must be tailored to the physical and chemical limitations of the situation. Passive soil vapor extraction offers a lower cost method to remove the residual contamination. 
2. What are the technology's objectives? (How does it satisfy the needs identified above?)

a. What are the objectives of this technology (for example, will this technology destroy VOCs in groundwater)?

The objective of the technology is to use fluctuations in natural atmospheric pressure and the gradients they produce between air at the surface and air in the subsurface to create a flow of contaminant-laden air from the subsurface to the surface.

\section{b. What is the technology that is currently used for this application (baseline technology)?}

The current baseline technology is active vapor extraction (commonly called Soil Vapor Extraction, or SVE). Active SVE uses vacuum systems which require power to operate. Twenty years or longer is often necessary to remediate a site to acceptable contaminant levels. The removal rate achieved by active SVE is initially high, followed by a rapid rate decline to a steady-state removal rate. This rate is determined by distribution of the contaminant in the substrate, and does not increase substantially with increased vacuum. When this condition is reached, the economic efficiency is low, due to power costs. The high cost of contaminant removal during this low removal rate time is difficult to justify, because there is only a marginal reduction of risk.

3. Process Description (Please describe the technology in terms that can be easily understood by interested members of the public. Include information on where the technology is applied - in place or above ground - what media the technology is used in - soil, groundwater, air - and what contaminants the technology targets.)

Fluctuations in atmospheric pressure occur due to weather and seasonal changes. These fluctuations create differential pressure between the atmosphere and air entrained in unsaturated subsurface soils. This approach to remediation uses these differences in air pressure. If the two zones are connected (by a well or borehole), air flow results. If the subsurface contains a volatile contaminant, this contaminant will be carried with the air flow to the surface. Since the driving force (atmospheric pressure fluctuations) of this removal process occurs naturally, this remediation method is inherently inexpensive. The key to its effective use is an understanding of the pressure relationship between the surface and subsurface at a given site under various atmospheric conditions. This knowledge can be used to accurately install pathways (e.g., vadose zone boreholes and wells) to effect contaminant removal. The flow through these pathways can then be controlled or enhanced to facilitate contaminant removal. The following table presents potential enhancements that will be part of the demonstration, and describes their expected effects. 
PSVE Potential Enhancements

\begin{tabular}{|c|c|}
\hline Enhancement & Projected Effect/Benefit \\
\hline Wind-driven turbines on the off-gas stack & $\begin{array}{l}\text { Amplify volume of air extracted by passively } \\
\text { increasing the pressure differential in the well. }\end{array}$ \\
\hline Venturi on off-gas stack & $\begin{array}{l}\text { Amplify volume of air extracted by passively } \\
\text { increasing the pressure differential in the well. }\end{array}$ \\
\hline Windmill on the off-gas stack & $\begin{array}{l}\text { Amplify volume of air extracted by passively } \\
\text { increasing the pressure differential in the well. }\end{array}$ \\
\hline One-way flow valve & $\begin{array}{l}\text { Control air flow direction through borehole which } \\
\text { will lead to contaminant plume migration control } \\
\text { and increased extraction efficiency. }\end{array}$ \\
\hline Hot air, stream, or nutrient injection & $\begin{array}{l}\text { Contaminant plume migration control, increased } \\
\text { extraction efficiency, or degradation of } \\
\text { contaminants in place. }\end{array}$ \\
\hline $\begin{array}{l}\text { Off-gas treatment: Collection on GAC or other } \\
\text { absorbent }\end{array}$ & Reduced VOC in off gas. \\
\hline $\begin{array}{l}\text { Off-gas treatment: Destruction by photocatalytic } \\
\text { or energy process }\end{array}$ & Reduced VOC in off gas. \\
\hline $\begin{array}{l}\text { Interconnected or systemically controlled well } \\
\text { networks }\end{array}$ & $\begin{array}{l}\text { Control of contaminant plume migration rate and } \\
\text { direction. }\end{array}$ \\
\hline
\end{tabular}

\section{What is the status of the technology's development?}

This remediation method is operational, and is being tested in basic configurations. In some cases, demonstration wells are open to the atmosphere; in other cases off-gas capture devices are being employed. In some cases, operational demonstration wells were existing and have been retrofitted for the demonstration; in other cases, new wells or borings have been installed. The dynamics of the process are being studied to understand and optimize removal, to minimize plume spread, and to effectively use the specific circumstances of given situations. 
5. Summary of Technology Advantages (compared with the baseline technology: Is it faster, better, cheaper, safer?)

This remediation method is significantly less expensive than the baseline of active soil vapor extraction (ASVE). Once a low removal rate is reached with the baseline technology, then the passive removal technology is more cost effective. The demonstration will attempt to quantify advantages and limitations.

\section{Summary of Technology Limitations (compared with the baseline technology)}

The rate of VOC removal is slower than the baseline technology. The demonstration will quantify rates and costs.

\section{Major Technical Challenges for the Technology}

Understanding the dynamics of the atmospherically driven removal process requires measurement over a period of time sufficient to characterize the broad range of atmospheric changes and conditions that can occur. These measurements must then be understood and compared with contaminant removal rates. After gathering and understanding these measurements, the process must be designed, and the parameters of operation must be set and controlled, both in general and at a specific particular site.

\section{Technical Effectiveness: Performance Criteria}

a. What contamination will remain after the technology is applied? (Will the mobility of the contamination be reduced? Will the volume be reduced? Will the contaminant be less toxic? This criterion applies primarily to retrieval treatment technologies.)

PSVE is a removal method. When operated for a sufficient period of time and under the proper conditions, residual VOC contamination in the vadose zone will be appreciably reduced. The mobility of VOC contamination within the soil will be steadily reduced over the course of operating the technology, because removal reduces concentration and volume of VOCs present in the subsurface environment. Concentrations of VOCs in the groundwater beneath the area treated by PSVE will also be reduced, since contamination in the vadose zone contributes to groundwater contamination.

b. What process waste (secondary waste) does the technology produce? (Is the secondary waste mobile? What is its volume? What hazards are associated with the secondary waste? Can it be recycled?)

Contaminant-laden air is removed from the subsurface and brought to the surface. If this air is contained (for example on GAC) or treated, then secondary waste is created. Details of off-gas treatment and management options for any secondary wastes will be included in the demonstration and in subsequent analysis of results. 
If the off gas is not contained or treated, it constitutes the secondary waste from PSVE. The concentration and total amount of VOC in this waste stream will be measured as part of the demonstration. Potential hazards will be evaluated.

\section{c. Describe the treatment or storage needed for the secondary waste and its availability.}

The contaminant is removed from the subsurface and introduced to the air at the surface, where it can be treated by active treatment methods (e.g. thermal, free-radical, photolytic, high energy, carbon adsorption), or allowed to disperse and react in natural atmospheric processes. Dispersion and solar and atmospheric processes can break down the contaminants. The off-gas management method selected depends on the amount of contaminant removed, the rate of removal, applicable regulations, and the particular contaminant.

\section{d. Describe the requirements for decontamination or decommissioning of equipment.}

The wells used for PSVE can be left in place and filled with grout. Decontamination and decommissioning of wells and boreholes is achievable.

\section{e. How must the secondary waste be disposed? Is disposal available?}

The disposal of process off gas, if it is not captured, depends on regulatory limits regarding the release of volatile contaminants to the atmosphere. Treatment methods for off-gas may produce secondary waste. Disposal and treatment methods for spent GAC and other off-gas treatment residuals are generally available.

\section{f. What future cleanup options are precluded by this technology? (Applies primarily to treatment technologies)}

No future cleanups are precluded by this technology.

g. How reliable is the technology? (Please address potential breakdowns, effectiveness, and sensitivity to operating conditions).

This technology is very reliable. Because the motive force to extract contaminants is naturally occurring, the only moving parts are those associated with control valves, recording equipment (if used), and off-gas treatment . Low-power solid state electronics may be used to control and operate valves and recording equipment. This technology is expected to operate effectively for years with no intervention.

h. If the technology fails, how are the effects of the failure controlled?

Electronic and mechanical control systems are being used in the demonstration. One system has a "watchdog" timer that can reset control in the event of electric disturbances. One-way valves can be 
set to close in the event of power or other system failures. Because the flow of contaminant-laden air is relatively slow, no safety hazards are anticipated in the event of a failure.

i. How easy is the technology to use? (Please describe the level of skills and training required to use the technology.)

Operational control of the system is automated and the motive force is naturally occurring. Therefore, the system is very easy to operate.

\section{j. What infrastructure (buildings, power sources, personnel) is needed to support the technology?}

Because of the passive nature of the process limited infrastructure is required. Examples include: a rechargeable battery or a solar panel to power the control and valve system and an enclosure for recording devices. Staff is required to change out the off-gas control system components, and to retrieve collected data.

$k$ How versatile is the technollogy? (That is, can it be applied to other types of contamination, in other media, or at other locations?)

The technology can be applied at a variety of sites that have volatile contaminants in the unsaturated zone. The system can also be used to enhance removal or biodegradation by supplying the subsurface with air, heat, or nutrients. In this mode, the technology can be applied to any contaminant that is volatile or biodegradable.

I. Describe the technology's compatibility with other elements of the system. (Please include a general description of the system.)

This technology can be used in conjunction with any other treatment or removal strategy. The volatilization of VOCs from the soil, either through soil pore spaces or other avenues (wells or boreholes), occurs naturally under common atmospheric conditions. Pressure gradients causing contaminant-laden air to flow out of wells have even been observed during active vapor extraction.

m. Can the technology be procured "off the shelf'? (Is it an innovative use of an existing technology?) Which components are available and which must be developed?

The basic technology components are available off the shelf. The process can be used in its most basic mode without valves or off-gas treatment (open venting). In both the enhanced and un-enhanced mode, installation and completion components are readily available. 
n. How difficult is the technology equipment to maintain? (Please include information on frequency as well as ease of maintenance. Also describe the level of skill or training required to maintain the technology.)

The technology should require no maintenance besides periodic inspections of any control and recording equipment (monthly initially, then yearly). This maintenance will not be necessary if the most basic form of the remediation method is used with no control or recording equipment or off-gas capture systems.

o. What equipment safety measures (such as automatic shutdown devices) are needed and in place to protect workers and the public?

In the valved system, the controller hardware and software can be programmed to close the valves on the wells, should that be necessary. For non-valved wells, no special safety measures are planned.

p. Describe the technology's ability to function as intended. (Does the technology work as intended? If not, describe functional problems.)

The process has been demonstrated in several basic configurations and functions as intended. The enhancements to the process, such as valving and well network controls, are being demonstrated to determine their effectiveness.

q. What are the scale-up issues and how are they being addressed?

Scale-up issues include determining the mass of VOCs removed by, and the zone of influence of, individual wells. This is dependent on site features. Tests are being conducted to understand and define these issues and determine how to appropriately scale up use of PSVE.

9. Cost (Please include assumptions on which you base your estimates.)

a. What is the start-up cost of the technology (including development costs, procurement and construction, permitting, and other costs necessary to begin operation)?

Installation and completion for a $100^{\prime}$ deep well can cost between $\$ 500$ and $\$ 2,000$, depending on site conditions and the drilling equipment used.

Control equipment is generally inexpensive and is expected to be less than $\$ 100$ per well (or borehole). The cost of off-gas treatment equipment varies.

b. What are the operations and maintenance costs of the technology?

Excluding off-gas treatment systems, it is anticipated that the operations and maintenance cost will be extremely low. The demonstration will quantify these costs. 
c. What are the life cycle costs of the technology (including facility capital cost; startup, operation, and maintenance; decommissioning, regulatory, or institutional oversight; and future liability)?

With an expected life of at least 30 years, the life cycle cost per well is anticipated to be very low. The demonstration will collect cost data to support determination of life cycle costs.

10. Time

a. When will the technology be available for commercial use or use at other sites?

The technology is expected to be available for commercial use by late 1995 .

b. What is the speed or rate of the technology? (Please use metrics)

The rate of the technology is dependent on the particular site but has been measured to date ranging from 0.1 to 2 kilograms of VOC removed per day per borehole.

c. At the speed or rate identified in 10(b), what is the total time required for the technology to achieve its objectives?

The time required to achieve acceptable conditions is dependent on the number of wells employed, the nature and concentration of contaminants, and the site. The demonstration will attempt to quantify the time required for satisfactory completion of remedial action over a range of conditions.

\section{Environmental Safety and Health: Worker Safety}

a. What potential is there for workers to be exposed to hazardous materials and/or other hazards? Describe those materials and hazards.

Worker exposure risks are expected to be minimal because the well control systems (if used) are automated, and power sources are renewable. Well air flow is low, installation exposures are well understood, and releases from the well heads are being monitored during the demonstration.

b. What are the physical requirements for workers?

There are no special physical requirements for workers. 
c. How many people are required to operate the technology?

None for routine operation, because it is either a natural or an automated system and once it is installed it works by itself. Workers are required to change out off-gas control devices (if used) and to retrieve data.

12. Environmental Safety and Health: Public Health and Safety

a. What is the technology's history of accidents? (Has there been a history of accidents and, if so, what was the nature of the accidents.)

No accidents have been experienced or are anticipated due to the passive nature of the extraction and the low flux rate of contaminated air out of the wells.

b. Does this technology produce routine releases of contaminants?

Yes, the technology produces routine releases of contaminants at low flow rates. These releases can be captured and treated.

c. Are there potential impacts from transportation of equipment, samples, waste, or other materials associated with the technology?

There are no transportation issues in most cases. The only exception is transportation off-site of spent off-gas treatment materials.

\section{Environmental Impacts}

a. What impact will this technology have on the ecology of the area (for example, wildlife, vegetation, air, water, soil, or people)?

Unknown at this time. The demonstration will monitor for potential effects.

b. What aesthetic impacts does the technology have (for example, visual impacts, noise)?

This technology has a very low profile. The technology can be designed so that minimal adverse aesthetic impacts are produced and so that the equipment at each well head is small and quiet.

c. What natural resources are used in the technology's development, manufacture, or operation? (Address energy resources in 13[d].)

The technology is driven by natural atmospheric pressure fluctuations and the control and measurement equipment (if used) can be driven by solar power, wind, or battery. 


\section{d. What are the technology's energy requirements? (Use metrics)}

The basic technology, without control systems or off-gas treatment, uses natural atmospheric pressure as its only energy.

\section{Socio-Political Interests: Public Perception}

a. What is the reputation of the technology's developer and/or user? (Principal investigators: this is a point of discussion for stakeholders; do not answer.)

b. How familiar is the technology to the public?

The public is believed to be generally unfamiliar with this technology.

c. How easy is the technology to explain to the public?

This process and the natural phenomenon driving it are very easy to explain and understand.

\section{Socio-Political Interests: Tribal Rights/Future Land Use}

a. How will the technology afiect future unrestricted use of land and water?

No negative effects are expected. Return of subsurface soils to pristine conditions would allow unrestricted future land use. Removal or abandonment of wells and boreholes may be required.

\section{Socio-Economic Interests}

a. What are the potential ecomomic impacts of this technology? (For example, what are the effects on the economic base of the community? Are there infrastructure requirements?)

Cleanup can be achieved at a much lower cost with this technology than is presently achievable.

b. How will the technology affect labor force demands?

Little labor is required for this technology. 


\section{Regulatory Objectives}

a. Describe the technology's compatibility with cleanup milestones.

This technology can achieve similar cleanup residual levels to the baseline technology (ASVE) at a much lower cost. The demonstration will attempt to determine the time required for this technology to achieve acceptable results.

\section{b. How familiar are regulators with this or a similar technology?}

Most regulators are unfamiliar with the technology, but it is easy to explain.

c. What is the technology's regulatory track record?

Regulators have been favorable to this technology on a demonstration basis at the Hanford Site, Idaho National Engineering Laboratory, and the Savannah River Site. However, the regulatory infrastructure and method of dealing with this technology on a fully deployed basis is currently unknown.

\section{d. How does the technology comply with applicable regulations?}

This technology reduces the subsurface concentration and mass of VOC contaminants. Air quality regulations and this technology's ability to comply with those will be analyzed during and after the demonstration.

\section{Industrial Partnerships}

a. What is the name of the industrial partner?

No individual partner is identified at this time.

b. What is the rationale for this partnership?

NA

c. What is the contract mechanism?

NA

d. Are there other potential partners?

There are believed to be potential partners because this is a low cost technology that is accessible to small and large businesses. 


\section{e. Are there potential international partners?}

There are believed to be potential international partners because this is a low cost technology that is applicable to volatile contamination found worldwide.

\section{Intellectual Property}

a. Who owns the patent for this technology?

Patents are pending for various enhancements. The PSVE process is natural and cannot be patented.

\section{b. Are there other patent owners?}

No other patent owners are known.

\section{c. Is there a patent number for this technology?}

Patent Number SRS-93-217 (This patent number is for a specific enhancement used at the Savannah River demonstration site)

\section{Cost Sharing}

a. What is the background of this technology? (Where did the idea come from? Who else is doing similar work? What have the results been to date? What is the most significant competitor to this technology?)

The subsurface to surface flow of air induced by atmospheric pressure changes has been observed for a long time. The first reference found in the literature was 1906 but it is doubtful that this is the first observation. A PSVE team has been formed as a result of the interest by the Arid Sites Integrated Demonstration Program consisting of researchers from Westinghouse Hanford Company (WHC), Pacific Northwest Laboratory (PNL), Lawrence Livermore National Laboratory (LLNL), Los Alamos National Laboratory (LANL), Idaho National Environmental Laboratory (INEL), U.S. Environmental Protection Agency (EPA), Westinghouse Savannah River Company (WSRC), and industry partners. WHC and INEL have incorporated the technology into their environmental restoration activities (EM40) and WSRC is also planning to implement it in their EM-40 activities.

\section{References}

Buckingham, E. (1904) Contributions to our knowledge of the aeration of soils. U.S. Department of Agriculture Bureau of Soils Bulletin, 25, 7.

Massman, J. and Farrier, D. F. (1992) Effects of atmospheric pressures on gas transport in the vadose zone. Water Resources Research, 28(3), 777. 
Rohay, V. J. and Cameron, R. J. (1992) Field measurements of natural soil-gas venting cycles in boreholes at the Hanford Site, Washington. Eos Transactions. American Geophysical Union 1992 Fall Meeting, 73(43), 238.

Rossabi, J., Looney, B. B., Eddy-Dilek, C. A., Riha, B., and Rohay, V. J. (1994) Passive Remediation of Chlorinated Volatile Organic Compounds Using Barometric Pumping. Proceedings of Innovative Solutions for Contaminated Site Management, Miami, FL., 377.

Weeks, E. P. (1978) Field determination of vertical permeability to air in the unsaturated zone. Geological Survey Professional Paper 1051.

Rohay, V.J., Rassabi, J., Looney, B.G., Cameron, RJ., and Peters, B.B., (1993) "Well Venting and Application and Passive Soil Vapor Extraction at Hanford and Savannah River," Proceedings of the ER '93 Conference, U.S. Department of Energy Environmental Remediation Conference, p. 815-818. 
TUNABLE HYBRID PLASMA TREATMENT

c:lwp51/workinglbatellelothrsitelarid2 


\title{
Technology Information Profile Tunable Hybrid Plasma
}

\author{
Full Name of the Technology: Tunable Hybrid Plasma \\ Principal Investigators: $\quad$ Richard M. Patrick, Massachusetts Institute of Technology \\ (617) 253-8790 \\ Daniel R. Cohn, Massachusetts Institute of Technology \\ (617) 253-5524 \\ Leslie Bromberg, Massachusetts Institute of Technology \\ (617) 253-6919
}

Technology Category: Treatment

Developed by: $\quad$ Massachusetts Institute of Technology (MIT)

1. What is the need for the technology? (If this technology is part of a system of technologies, what is its role in the system, and what is the need for the system?)

Most Department of Energy (DOE) sites are contaminated with volatile organic compounds (VOCs). Specifically, there are 220 sites in arid environments with VOC contamination. Efficient, economical technologies are needed to treat this contamination once it has been removed from the ground.

The Tunable Hybrid Plasma technology provides important improvements over current baseline technology in efficiency, cost, versatility, and availability of on-site treatment for remediating VOC contamination.

2. What are the technology's objectives? (How does it satisfy the needs identified above?)

a. What are the objectives of this technology? (for example, will this technology destroy VOCs in groundwater?)

The objective of this technology is to provide, through the use of an electron beam process, the versatile, on-site treatment of gaseous toxic and hazardous compounds, particularly carbon tetrachloride and trichloroethylene, with minimal creation of undesirable byproducts (secondary waste), and minimal need for additional treatment. Tunable Hybrid Plasma destroys vapor phase VOCs including those in air streams generated by stripping VOCs from groundwater. 


\section{b. What is the technology that is currently used for this application (baseline technology)?}

Soil vapor extraction is the baseline technology for remediating contamination in vadose zone soils. The baseline treatment technology for extracted VOCs is adsorption onto granulated activated carbon (GAC) with off-site regeneration of GAC.

3. Process Description. (Please describe the technology in terms that can be easily understood by interested members of the public. Include information on where the technology is applied - in place or above ground - what media the technology is used in - soil, groundwater, air - and what contaminants the technology targets.)

The technology is applied above ground. A moderate-energy electron beam (100-300 $\mathrm{keV}$ ) is directed into a flow of air containing organic contaminants. An electron beam consists of electrons moving at high speed initially through gas such as air. The electron beam is produced by applying electricity to a linear filament electron source in a vacuum chamber. Electrons thus generated pass through a titanium foil "window." The titanium foil allows the electrons but not the air to pass into the vacuum.

Electron beams are in widespread commercial use, particularly in the paper industry. Specifically, they are used in the lamination process that makes cereal boxes. The titanium duct that directs the flow of electrons, as well as the electron generating apparatus, are shielded with lead. The entire apparatus is contained in and transported on a tractor trailer.

The primary electrons that pass through the titanium foil, with energies approximately equal to $200,000 \mathrm{eV}$, create several thousand secondary electrons. These secondary electrons have lower energy levels than the primary electrons that come from the filament. The major reason for the energy transfer is the impact of the primary electrons on the orbiting electrons of the molecules in the carrier gas (air). Those "collisions" create electron/ion pairs (plasma).

The secondary electrons, which are much greater in number than the primary electrons, rapidly cool to room temperature due to collisions in the air. The secondary electrons attach to the halogenated hydrocarbon molecules in the waste gas stream causing the VOC molecules to dissociate. This occurs preferentially because of the way the molecules are arranged. Technically, the "attachment cross-sections" of molecules like carbon tetrachloride are extremely large, allowing for ready attachment of the secondary electrons. This accounts for the preferential destruction of carbon tetrachloride.

A soil vapor extraction system makes contaminants entrained in the air stream available for destruction by the electron beam. Tunable Hybrid Plasma is compatible with a number of soil gas retrieval technologies. 
The end products of this process, due to dissociative attachment, are carbon dioxide, chlorine gas, water, oxygen, nitrogen, and hydrochloric acid. The products of the reaction of carbon tetrachloride destruction are passed through the liquid of a conventional wet scrubber, which removes soluble contaminants. Chlorine gas and hydrochloric acid dissolve in the aqueous solution. The scrubber's solution can contain a caustic such as sodium hydroxide (lye). The caustic solution is preferred because it produces salt $(\mathrm{NaCl})$ after scrubbing out the chlorine, which can be easily disposed of. The gases that do not dissolve in the aqueous solution (carbon dioxide, oxygen and nitrogen) pass through and are released into the atmosphere.

\section{What is the status of the technology's development?}

Tunable Hybrid Plasma is a new use of existing technology. The technology has been demonstrated in the MIT laboratory. Carbon tetrachloride has been converted to chlorine gas and hydrochloric acid, which have been dissolved in an aqueous solution of sodium hydroxide and converted to salt.

The electron beam unit for the field demonstration at the Hanford Site in Washington state has been delivered to MIT. The field test system is fully operational and has been operated autonomously with a personal computer and modem.

5. Summarize the advantages of the technology (compared with the baseline technology - Is it faster, better, cheaper, safer?)

The advantages of this technology include:

- It provides on-site treatment of toxic substances in gas stream with high destruction and removal efficiency.

- It eliminates contaminants from high-volume waste gas streams with end products of small volumes of solid precipitates and non-toxic gases.

- It operates at a relatively low cost. The objective is to treat one pound of carbon tetrachloride for about $\$ 4$. The costs for destroying trichloroethylene are lower, approximately 40 cents per pound.

- It entails minimum pre- and post-treatment requirements.

- It has the capability to treat gases from solid waste treatment systems, resulting in non-toxic emissions and small volumes of solid non-toxic residues.

- It offers versatile operation to process a wide range of contaminants and concentrations. 
- It has the capability to operate without onsite personnel, requiring only periodic maintenance.

- It has the capability of destroying VOCs over a very wide range of initial concentrations, while maintainig high efficiency and low cost.

\section{Summary of Technology Limitations (compared with the baseline technology)}

The technology's effectiveness is limited at very high concentrations of contaminants where other processes become cost competitive.

\section{Major Technical Challenges}

The major technical challenge for this technology is to remove carbon tetrachloride and similar toxic compounds from waste gas streams containing dilute concentrations of toxic gases. The system must inclucle the electron beam apparatus, scrubber, and a control system in order to be fully automated, and be cost competitive with other methods that carry out the same function.

\section{Technical Effectiveness: Performance Criteria}

a. What contamination will remain after the technology is applied? (Will the mobility of the contamination be reduced? Will the volume be reduced? Will the contaminant be less toxic? This criterion applies primarily to retrieval treatment technologies.)

A field test system has been assembled and tested at MIT. It has been used to demonstrate the reduction in carbon tetrachloride concentration from $760 \mathrm{ppm}$ to $0.6 \mathrm{ppm}$ with a $99.97 \%$ removal efficiency.

Trichloroethylene (TCE) has been tested with the Tunable Hybrid Plasma technology. The destruction of TCE requires less than $10 \%$ of the energy needed to destroy carbon tetrachloride. The byproducts of the decomposition of TCE can be dissolved in an aqueous solution containing sodium hydroxide. The end product is a non-toxic sodium salt. The air stream need not have a low vapor pressure of water, eliminating the necessity of the air stream dryer required for the destruction of carbon tetrachloride.

Laboratory tests indicate that the products of the electron beam dissociation of carbon tetrachloride can be dissolved in an aqueous solution. This solution preferably contains a base such as sodium hydroxide that combines with dissolved hydrochloric acid and chlorine to form sodium chloride (salt). The remaining byproduct, carbon dioxide, can be released to the atmosphere. The salt is a non-hazardous waste that can be disposed of in a landfill if reduced to a solid. Brine solutions may be amenable to reuse. 
b. What process waste (secondary waste) does the technology produce? (Is the secondary waste mobile? What is its volume? What hazards are associated with the secondary waste? Can it be recycled?)

The initial action of the technology produces hydrochloric acid, chlorine gas, and carbon dioxide. Subsequent actions of the technology - scrubbing in a caustic aqueous solution reduces the hydrochloric acid to sodium chloride (salt).

c. Describe the treatment or storage needed for secondary waste and its availability.

After treatment in the scrubber, limited further treatment of the secondary waste (salt cake or brine) is required. Management is commonly available.

\section{d. Describe the requirements for decontamination or decommissioning of equipment.}

The technology's equipment requires no decontamination and only standard decommissioning.

e. How must secondary waste be disposed? Is disposal available?

This technology decomposes carbon tetrachloride into non-toxic carbon dioxide and salt (such as $\mathrm{NaCl}$ ). The salt may be disposed of as salt brine or evaporated and disposed as salt cake in a solid waste disposal facility. Disposal for these materials is available.

\section{f. What future cleanup options are precluded by this technology?}

The technology precludes no future cleanup options.

\section{g. How reliable is the technology? (Please address potential breakdowns, effectiveness, and sensitivity to operating conditions.)}

All of the principal components of the Tunable Hybrid Plasma system are standard items that have been manufactured for industrial use for several years. These include the major component, the electron beam, manufactured by Energy Systems, Inc. , Wilmington, Massachusetts. More than 100 nearly identical units have been built and sold over the last 20 years. The system's air dryer and scrubber are standard catalogue items that have been used in industry for many years.

Some of potential breakdowns are vacuum failure in the electron beam, clogging of the scrubber, failure of the computer control system, and failure of the sensors monitoring the system. 
h. If the technology fails, how are the effects of the failure controlled?

All failures are controlled by turning off the electron beam, which is done electronically. A computer will monitor the technology's functions and will be used to restart the system or aid in diagnosing the failure. The following will be monitored:

- VOC levels in the extracted air stream

- The air stream coming out of the apparatus

- Levels of halogens (chlorine type elements) inside the trailer

- Levels of hydrochloric acid going into the scrubber

- Radiation levels outside the lead shielding of the linear filament electron source

"Interlocks," electronic controls connecting monitors and shutdown devices, will automatically stop the electron beam if monitors record levels above programmed limits.

i. How easy is the technology to use? (Please describe the level of skills and training required to use the technology.)

A skilled technician is required for startup procedures for operation of the technology. Knowledge of the technology's monitoring and safety systems are required. Normal operation is fully automatic. System setup and startup require knowledge of personal computer operation using Windows.

j. . What infrastructure (buildings, power sources, personnel) is needed to support the technology?

Infrastructure requirements include electric power and make-up water for the scrubber. The unit will be contained in a 40-foot trailer; no other utilities will be necessary.

k. How versatile is the technology? (That is, can it be applied to other types of contamination, in other media, or at other locations?)

The technology can be applied to a wide variation of VOC concentrations - from $10 \mathrm{ppm}$ to $2000 \mathrm{ppm}$. It has been demonstrated to destroy carbon tetrachloride, chloroform, and trichloroethylene. Laboratory tests are planned to determine how many other VOC contaminants the Tunable Hybrid Plasma technology can destroy. 
1. Describe the technology's compatibility with other elements of the system. (Please include a general description of the system that the technology is part of.)

Tunable Hybrid Plasma is a treatment technology. It is compatible with all pumping systems and VOC air stripping technology that make contaminated air streams available for treatment.

m. Can the technology be procured "off-the-shelf?" (Is it an innovative use of an existing technology?) Which components are available and which must be developed?

All of the components are standard items manufactured in quantity. Tunable Hybrid Plasma is an innovative use of existing technology.

n. How difficult is the technology equipment to maintain? (Please include information on frequency as well as ease of maintenance. Also describe the level of skill or training required to maintain the technology.)

A skilled technician is required to perform such tasks as periodically maintaining the scrubber. All of the technology's components have been developed over a period of 20 years. Spare parts for all components will be available onsite, for example, a spare electron beam foil and foil holder.

0. What equipment safety measures (such as automatic shutdown devices) are needed and in place to protect workers and the public?

The Tunable Hybrid Plasma system includes two separate and redundant gas monitoring systems to monitor inlet, outlet and ambient air. The electron beam is completely interlocked, with safety monitoring devices that will shut down the technology if they detect unacceptably high levels of chemical contamination or radiation. The electron generating filament creates small amounts of $x$-rays and are shielded with lead to block exposure of workers or the public. The technology meets all Occupational Safety and Health Administration (OSHA) standards.

p. Describe the technology's ability to function as intended. (Does the technology work as intended? If not, describe functional problems.)

The technology's function has been successfully demonstrated several times including full operation of the field test system. 
q. What are the scale-up issues and how are they being addressed?

Cost analyses for field units are based on standard, large-scale, off-the-shelf components. This allows the prediction of performance and cost for units with 100 to 1, 000 times more capacity.

9. Cost (Please include assumptions on which you base your estimates.)

a. What is the start-up cost of the technology (including development costs, procurement and construction, permitting, and other costs necessary to begin operation)?

Only projected cost information is available at this time. Additional information concerning costs will be available in October 1995. A full-scale Tunable Hybrid Plasma system ( $175 \mathrm{~kW}$ electron beam that directs $100 \mathrm{~kW}$ into the contaminated gas stream) costs about $\$ 1$ million. This cost includes the electron beam and support equipment. The system is projected to treat about ten pounds of carbon tetrachloride per hour and operate $90 \%$ of the time. Hence, the system should be able to treat about 78,000 pounds of carbon tetrachloride a year. For a field unit, the objective is to treat one pound of carbon tetrachloride for about $\$ 4$. The cost of treating trichloroethylene is estimated to be less than 40 cents per pound.

b. What are the operations and maintenance cost of the technology?

Information about operation and maintenance costs will be available in October 1995.

c. What are the life cycle costs of the technology (including facility capital cost, startup, operation, and maintenance; decommissioning, regulatory, or institutional oversight; and future liability)?

These costs are not known at this time. Information will be available in October 1995.

10. Time

a. When will the technology be available for commercial use at other sites?

The goal is to have the technology available for commercial use by the fourth quarter of 1996.

b. What is the speed or rate of the technology?

The field unit to be used in the demonstration is capable of processing from one to 20 cubic feet per minute of contaminated air. Based on this rate, large scale units will be capable of processing 50 cubic meters per minute. 
c. At the speed or rate identified in $10 \mathrm{~b}$, what is the total time required for the technology to achieve its objective?

The total time required for the technology to achieve its objective will depend on the extent and concentration of contamination at the site of the technology's use.

\section{Environmental Safety and Health: Worker Safety}

a. What potential is there for workers to be exposed to hazardous materials and/or other hazards? Describe those materials and hazards.

All hazards, including radiation and emissions, are continuously monitored. Monitors are connected to electronic interlocks and a computer, which will shut down the apparatus if contaminants or $x$-ray levels exceed programmed limits. The linear filament electron source and the beam current control assembly are shielded with lead. Standard precautions for handling corrosive solutions need to be followed in operating and maintaining the scrubber.

\section{b. What are the physical requirements for workers?}

There are no special physical requirements for workers.

\section{c. How many people are required to operate the technology?}

Once started, the technology's operation is fully automatic, by telephone connection. A trained technician will be required to maintain the scrubber and to periodically observe other components of the system.

\section{d. Public Health and Safety}

What is the technology's history of accidents? (Has there been a history of accidents, and if so, what was the nature of the accidents?)

The technology has no history of accidents.

\section{e. Does this technology produce routine releases of contaminants?}

If the scrubber is operating properly no contaminants are released.

\section{f. Are there potential impacts from transportation of equipment, samples, waste, or other materials associated with the technology?}

The technology's end-product - non-toxic, chlorine based salt brine or salt cake - will have to be transported for final disposal in a solid waste landfill. 


\section{Environmental Impacts}

a. What impacts will this technology have on the ecology of the area (for example, wildlife, vegetation, air, water, soil or people)?

The use of this technology will have no impact on the ecology of the area where it is used, other than the transportation of its end product - salt brine or salt cake - to a permitted solid waste disposal facility.

b. What aesthetic impacts does this technology have (for example, visual impacts, noise)?

The technology will be transported in and operate from inside a 40-foot truck trailer which is moved after use of the technology.

c. What natural resources are used in the technology's development, manufacture or operation?

Metals, fossil fuels, and electricity are used in the technology's development and manufacture. Water and electric power are used in the technology's operation.

d. What are the technology's energy requirements?

A prototype unit of the technology uses $15 \mathrm{kVA}$. Large units use $200 \mathrm{kVA}$.

\section{Socio-political Interests: Public Perception}

a. What is the reputation of the technology's developer and user?

MIT and Metcalf \& Eddy are renowned institutions in the area of process development and commercialization.

b. How familiar is the technology to the public?

The public is probably unfamiliar with this technology.

c. How easy is the technology to explain to the public?

Explaining the technology to the public requires the following:

- a clear description of the creation and operation of a moderate energy electron beam

- a clear description of the interaction of the electrons in the electron beam with the VOCs entrained in the contaminated air stream 
- an explanation of the safety measures taken to shield the electron beam generating components of the technology and to prevent fugitive emissions of VOCs,

- an explanation of the measures taken to reduce secondary wastes to non-toxic end-products and to safely dispose of these end-products.

\section{Socio-political Interests: Tribal Rights/ Future Land Use}

a. How will the technology affect future unrestricted use of land and water.

The technology will promote the future unrestricted use of land and water by destroying VOCs in the soils of contaminated sites.

\section{Socio-Economic Interests}

a. What are the potential economic impacts of this technology? (For example, what are the effects on the economic base of the community? Are there infrastructure requirements?)

The technology will have minimal economic impact on the communities where it used because it has no special requirements for infrastructure, requires limited staff to operate, and is portable.

b. How will the technology affect labor force demands?

The technology will place very few demands on the labor force of the communities where it is used.

\section{Regulatory Objectives}

a. Describe the technology's compatibility with cleanup milestones.

The goal is to make the technology available in two years for multi-site use to promote the achievement of cleanup milestones.

b. How familiar are regulators with this or a similar technology?

Because Tunable Hybrid Plasma is a new use of technology, regulators are generally unfamiliar with it.

c. What is the technology's regulatory track record?

The technology has yet to develop a regulatory track record. 
d. How does the technology comply with applicable regulations?

The technology meets all applicable regulations for air emissions, byproduct disposal and radiation levels.

18. Industrial Partnerships

a. What is the name of the industrial partner?

Negotiations to establish an industrial partner are under way at this time.

b. What is the rationale for this partnership?

The selection criterion for an industrial partner for this technology is a large company involved solely in environmental cleanup to license MIT patents in the area of plasma technology.

c. What is the contract mechanism?

The contract mechanism is patent licensing.

d. Are there other potential partners?

Yes, but none are being pursued at this time.

e. Are there potential international partners?

Yes, but no negotiations are under way at this time. International partners will be sought in partnership with the licensee.

19. Intellectual Property

a. Who owns the patent for this technology?

The patent is held by the Massachusetts Institute of Technology as a subcontractor to Battelle Pacific Northwest Laboratories, a contractor to the United States Department of Energy.

b. Are there other patent owners?

No. 


\section{c. Is there a patent number for this technology?}

Yes. The patent number is U.S. 5, 256, 854 - Tunable Plasma Method and Apparatus

Using Radio Frequency Heating and Electron Beam Irradiation. In addition, MIT has submitted one other patent application.

\section{Cost Sharing}

N/A

21. What is the background of this technology? (Where did the idea come from? Who else is doing similar work? What have the results been to date? What is the most significant competitor to this technology?)

In the late 1970s, electron beams were shown to be an effective treatment for sulfur dioxide and nitrous oxide. However, little research has been carried out to determine the effects of electron beams on organic (carbon based) materials. Some research has been conducted in Germany to remove toluene, and AVCO Research Laboratory (R. Slater and D. Douglas Hamilton) used electron beams to destroy vinyl chloride. A combination of electron beam ionization and direct current electric fields was used to create low temperature plasmas used in the construction of large, powerful carbon dioxide lasers. This method was developed by scientists at the AVCO Research Laboratory in Everrett, Massachusetts. The same technology was used to develop very large pulsed carbon dioxide lasers for experiments at the Los Alamos National Laboratory. Combined electron beam and direct current electric fields, microwaves have not yet been used for treatment of toxic materials. Zapit Technology has recently completed a licensing agreement with Lawrence Livermore National Laboratory (LLNL) for an approach that uses high voltage electron beam radiolytic destruction of organic compounds. The LLNL work involved destruction of trichloroethylene using pulsed electron beam technology developed for military uses. This high voltage electron beam approach requires heavy shielding for $\mathrm{x}$-rays, and relatively large reaction chambers are needed to efficiently use the electron beam.

High energy electron beam processing of aqueous waste streams is presently being investigated by the University of Miami in conjunction with the Los Alamos National Laboratory. MIT uses electron beams with moderate voltages of up to $300 \mathrm{keV}$. This allows the construction of a system based on established electron beam technology which can be compact, portable, easily shielded and widely available .

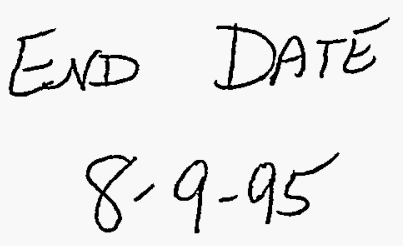

